University of Nebraska - Lincoln

DigitalCommons@University of Nebraska - Lincoln

2006

\title{
Use of Sediment Rating Curves and Optical Backscatter Data to Characterize Sediment Transport in the Upper Yuba River Watershed, California, 2001-03
}

\author{
Jennifer A. Curtis \\ U.S. Geological Survey \\ Lorraine E. Flint \\ U.S. Geological Survey \\ Charles N. Alpers \\ U.S. Geological Survey \\ Scott A. Wright \\ Boston College \\ Noah P. Snyder \\ Boston College
}

Follow this and additional works at: https://digitalcommons.unl.edu/usgspubs

Part of the Earth Sciences Commons

Curtis, Jennifer A.; Flint, Lorraine E.; Alpers, Charles N.; Wright, Scott A.; and Snyder, Noah P., "Use of Sediment Rating Curves and Optical Backscatter Data to Characterize Sediment Transport in the Upper Yuba River Watershed, California, 2001-03" (2006). Publications of the US Geological Survey. 63. https://digitalcommons.unl.edu/usgspubs/63

This Article is brought to you for free and open access by the US Geological Survey at DigitalCommons@University of Nebraska - Lincoln. It has been accepted for inclusion in Publications of the US Geological Survey by an authorized administrator of DigitalCommons@University of Nebraska - Lincoln. 
In cooperation with CALFED Ecosystem Restoration Program, California Bay-Delta Authority, and California Resources Agency

\section{Use of Sediment Rating Curves and Optical Backscatter Data to Characterize Sediment Transport in the Upper Yuba River Watershed, California, 2001-03}

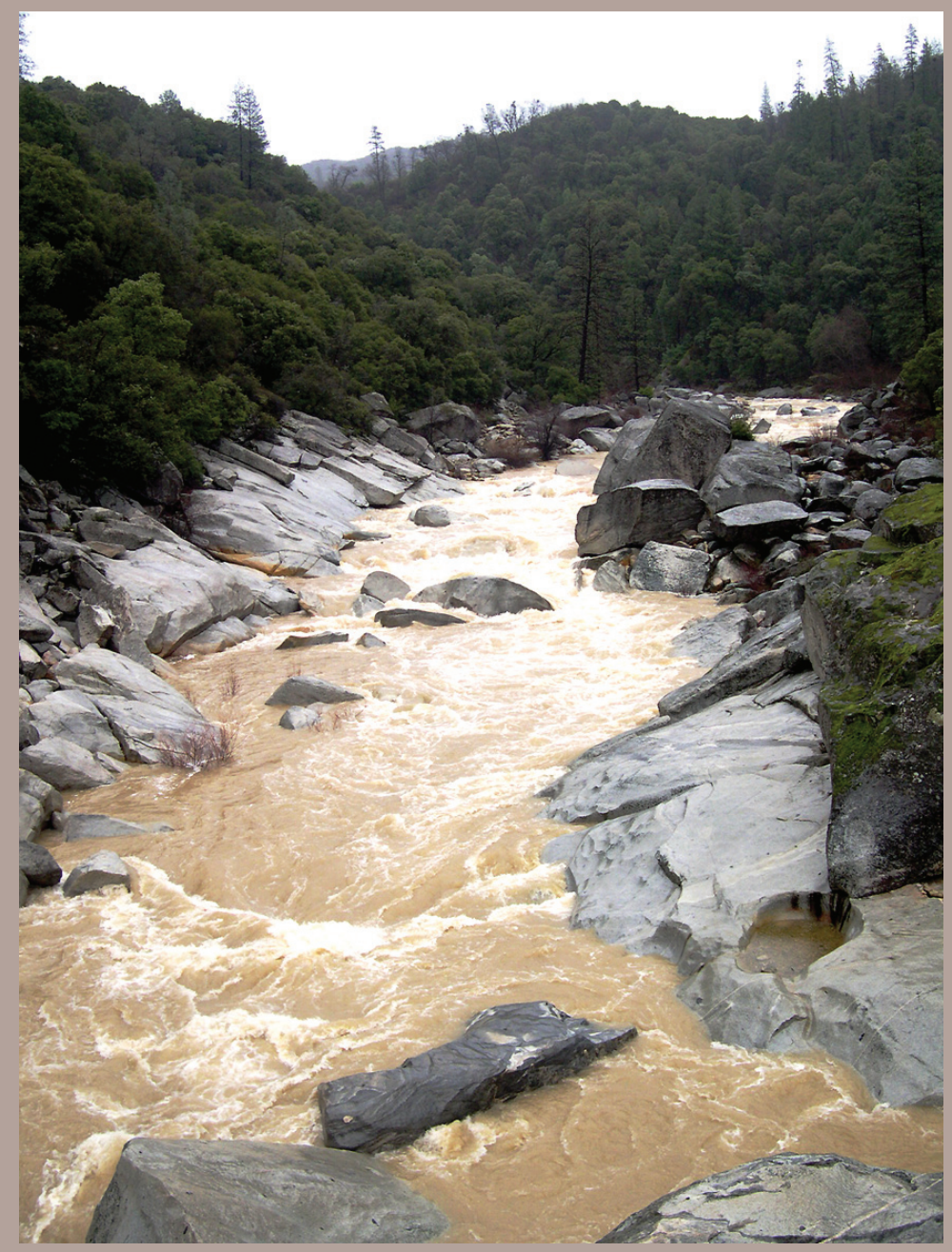

Scientific Investigations Report 2005-5246

U.S. Department of the Interior U.S. Geological Survey 
Photo on front cover:

South Yuba River, looking upstream from old Highway 49 bridge, Nevada County, California; February 25, 2004, discharge approximately 1,500 cubic feet per second, on rising limb of hydrograph. Photograph by C.N. Alpers. 


\section{Use of Sediment Rating Curves and Optical Backscatter Data to Characterize Sediment Transport in the Upper Yuba River Watershed, California, 2001-03}

By Jennifer A. Curtis', Lorraine E. Flint'1, Charles N. Alpers', Scott A. Wright' ${ }^{2}$, and Noah P. Snyder ${ }^{3}$

\section{U.S. Geological Survey Scientific Investigations Report 2005-5246}

Prepared in cooperation with CALFED Ecosystem Restoration Program, California Bay-Delta Authority, and California Resources Agency

1U.S. Geological Survey, California Water Science Center, 6000 J Street, Placer Hall, Sacramento, California 95819-6129.

${ }^{2} U . S$. Geological Survey, Southwest Biological Science Center, 2255 North Gemini Drive, Flagstaff, Arizona 86001.

${ }^{3}$ U.S. Geological Survey, Pacific Science Center, 400 Natural Bridges Drive, Santa Cruz, California 95060. Now at Department of Geology and Geophysics, Boston College, 140 Commonwealth Ave., Chestnut Hill, Massachusetts 02467.

Sacramento, California 


\title{
U.S. Department of the Interior \\ P. Lynn Scarlett, Acting Secretary
}

\author{
U.S. Geological Survey \\ P. Patrick Leahy, Acting Director
}

U.S. Geological Survey, Reston, Virginia: 2006

For Sale by U.S. Geological Survey, Information Services

Box 25286, Denver Federal Center

Denver, C0 80225-0286

For more information about the USGS and its products:

Telephone: 1-888-ASK-USGS

World Wide Web: http://www.usgs.gov

Any use of trade, product, or firm names in this publication is for descriptive purposes only and does not imply endorsement by the U.S. Government.

Although this report is in the public domain, permission must be secured from the individual copyright owners to reproduce any copyrighted materials contained within this report.

Suggested citation:

Curtis, J.A., Flint, L.E., Alpers, C.N., Wright, S.A., and Snyder, N.P., 2006, Use of Sediment Rating Curves and Optical Backscatter Data to Characterize Sediment Transport in the Upper Yuba River Watershed, California, 2001-03: U.S. Geological Survey Scientific Investigations Report 2005-5246, 74 p. 


\section{Contents}

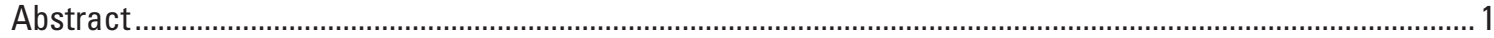

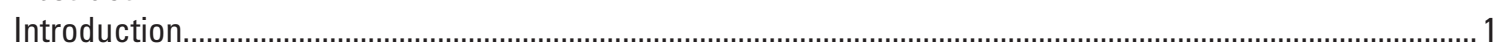

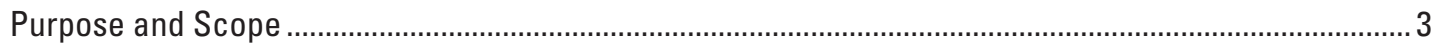

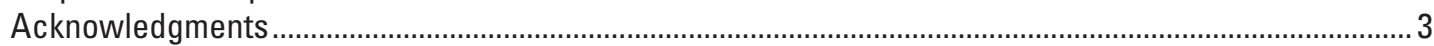

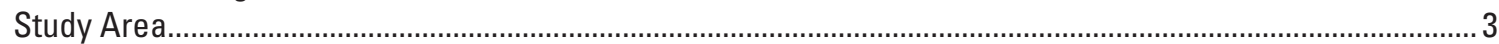

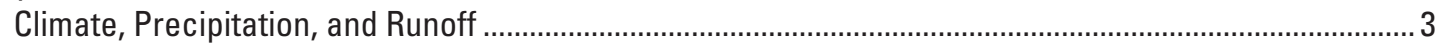

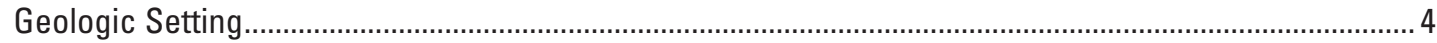

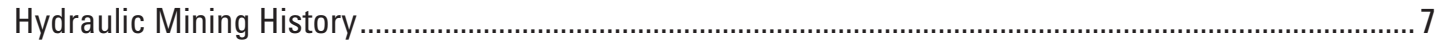

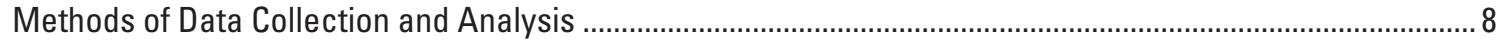

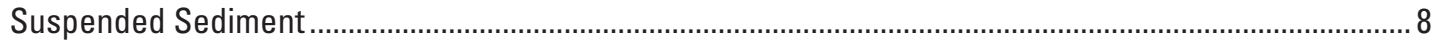

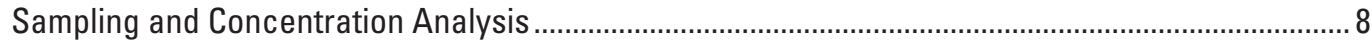

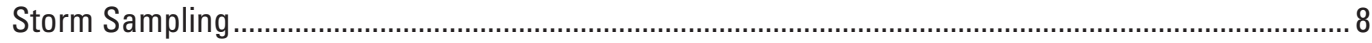

Grain-Size Analysis of Suspended Sediment...................................................................................

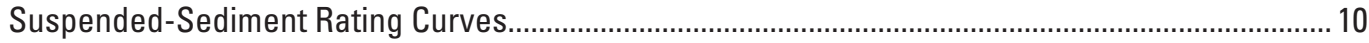

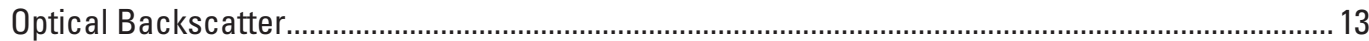

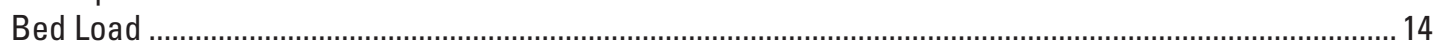

Bed Material Grain-Size Analysis.................................................................................................. 14

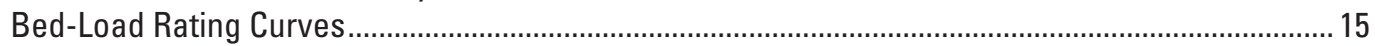

Shady Creek Bed-Load Measurements ........................................................................................... 16

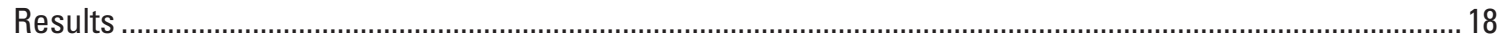

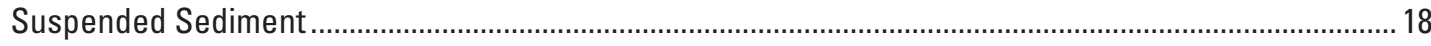

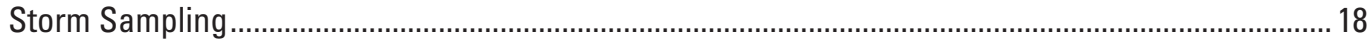

Grain-Size Analysis of Suspended Sediment................................................................................... 18

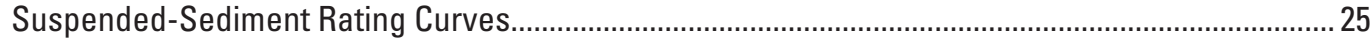

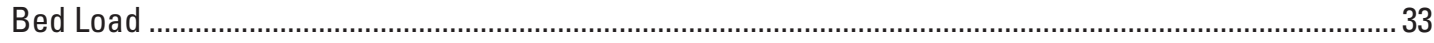

Bed-Load Rating Curves..................................................................................................................... 33

Shady Creek Bed-Load Measurements.............................................................................................. 33

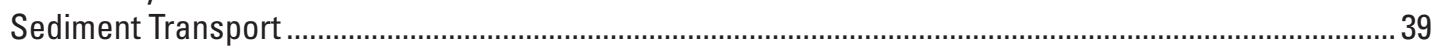

Annual Sediment Discharge ....................................................................................................... 39

Event-Based Suspended-Sediment Discharge _................................................................................... 41

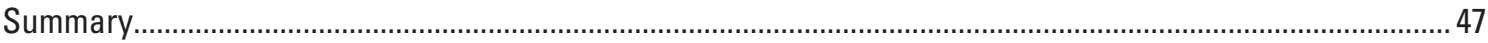

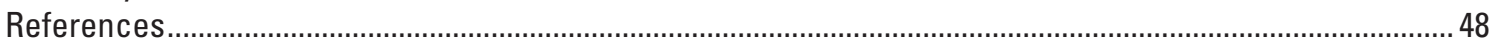

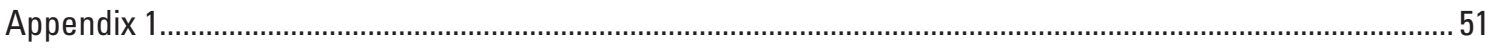

Appendix 2 


\section{Figures}

1. Location of sediment and streamflow gaging stations, study area of the Upper Yuba River Studies Program (UYRSP), and the upper Yuba River watershed, California..

2. Annual peak streamflows measured from 1942 to 2003 for the gaging station on the Yuba River below Englebright Dam (YRE, 11418000) in the upper Yuba River watershed, California.....................4

3. Stream diversions and reservoir storage in the upper Yuba River watershed, California ...............................5

4. Hydraulic mining at Malakoff Diggings (circa 1876), located in the South Yuba River watershed, California. . .7

5. Relation of suspended-sediment concentration to instantaneous streamflow by season for the four gaging stations in the upper Yuba River watershed, California...

6. Location of bed-load sampling sites and cross-section bed-load transport locations along Shady Creek in the upper Yuba River watershed, California.

7. Cumulative percentage of the grain-size distribution of bed-surface material for bed-load sampling sites located in Shady Creek and two gaging stations on the Middle Yuba River (11410000) and South Yuba River (11417500) in the upper Yuba River watershed, California.

8. Mean velocity and streamflow relations for gaging stations on the Middle Yuba River

(11410000) and South Yuba River (11417500) in the upper Yuba River watershed, California.

9. Instantaneous streamflow, suspended-sediment concentrations, and percent sand of suspended sediment during storm events at the Middle Yuba River (11410000) and South Yuba River

(11417500) gaging stations in the upper Yuba River watershed, California.

10. Relation between percent sand (the proportion of suspended-sediment larger than 0.063 millimeter) and instantaneous streamflow for two gaging stations in the upper Yuba River watershed, California.

11. Non-linear regression relations between suspended-sediment concentration and instantaneous streamflow for the Middle Yuba River (11410000) and South Yuba River (11417500) gaging stations in the upper Yuba River watershed, California.

12. Ratio of bed-load transport to instantaneous streamflow for the Middle Yuba River (11410000) and South Yuba River (11417500) gaging stations in the upper Yuba River watershed, California.

13. Extensive volumes of historical hydraulic-mining sediment are located in Shady Creek, a tributary to the South Yuba River in the upper Yuba River watershed, California

14. Relation of bed-load transport and instantaneous streamflow, and bed-load measurements for bed-load sampling sites on Shady Creek, a tributary to the South Yuba River in the upper Yuba River watershed, California.

15. Cumulative grain-size distributions for bed-load samples collected on Shady Creek, a tributary to the South Yuba River in the upper Yuba River watershed, California.

16. Ratio of suspended-sediment concentration to optical backscatter sensor output voltage as a function of suspended particles finer than 0.063 millimeter for two gaging stations.

17. Relation of suspended-sediment concentration and optical backscatter sensor (OBS) output for two gaging stations in the upper Yuba River watershed, California.

18. Instantaneous streamflow and suspended-sediment concentrations (SSC) during storm events at the Middle Yuba River (11410000) and South Yuba River (11417500) in the upper Yuba River watershed, California. 


\section{Tables}

1. Summary of streamflow and suspended-sediment measurements for four sites in the Upper Yuba River watershed, California, during water years 2001, 2002, and 2003.

2. Summary of streamflow, suspended-sediment concentrations, and grain sizes of sand-sized suspended sediment at gaging stations in the upper Yuba River watershed, California.

3. Summary of streamflow, suspended-sediment concentrations, and grain sizes of suspended sediment collected at gaging stations in the upper Yuba River watershed, California...........24

4. Regression equation form and statistics for gaging stations in the Middle Yuba and South Yuba rivers in the upper Yuba River watershed, California...

5. Measured bed load and predicted bed-load transport rates for two sites along Shady Creek in the upper Yuba River watershed, California.

6. Annual sediment discharge and bed-load estimates for gaging stations on the Middle Yuba and South Yuba Rivers in the upper Yuba River watershed, California..

7. Annual suspended-sediment discharge for gaging stations on the Middle Yuba (MYG) and South Yuba (SYG) Rivers in the upper Yuba River watershed, California.

8. Event-based suspended-sediment discharge at gaging stations on the Middle Yuba and South Yuba Rivers in the upper Yuba River watershed, California.

A1a. Suspended-sediment concentration samples and associated instantaneous streamflow for the Middle Yuba River near North San Juan (MYG) collected during water years 2001, 2002, and 2003.

A1b. Suspended-sediment concentration samples and associated instantaneous streamflow for the South Yuba River at Jones Bar near Grass Valley (SYG) collected during water years 2001, 2002, and 2003.

A1c. Suspended-sediment concentration samples and associated instantaneous streamflow for the Yuba River below New Colgate Powerplant near French Corral (YRC) collected during water years 2001, 2002, and 2003.

A1d. Suspended-sediment concentration samples and associated instantaneous streamflow for the Yuba River below Englebright Dam near Smartville (YRE) collected during water years 2001, 2002, and 2003.

A2. Grain-size distributions for suspended sediment collected during water year 2003. 


\section{Conversion Factors}

\section{SI to Inch/Pound}

\begin{tabular}{lcl}
\hline \multicolumn{1}{c}{ Multiply } & \multicolumn{1}{c}{ By } & \multicolumn{1}{c}{ To obtain } \\
\hline centimeter $(\mathrm{cm})$ & 0.3937 & inch \\
cubic meter $\left(\mathrm{m}^{3}\right)$ & 0.0008107 & acre-foot \\
cubic meter per second $\left(\mathrm{m}^{3} / \mathrm{s}\right)$ & 35.31 & cubic foot per second \\
cubic meter per second $\left(\mathrm{m}^{3} / \mathrm{s}\right)$ & 70.07 & acre-foot per day \\
meter $(\mathrm{m})$ & 3.281 & foot $(\mathrm{ft})$ \\
millimeter $(\mathrm{mm})$ & 0.03937 & inch \\
square centimeter $\left(\mathrm{cm}^{2}\right)$ & 0.1550 & square inch \\
square centimeter $\left(\mathrm{cm}^{2}\right)$ & 0.001076 & square foot \\
square kilometer $\left(\mathrm{km}^{2}\right)$ & 0.3861 & square mile $\left(\mathrm{mi}^{2}\right)$ \\
square meter $\left(\mathrm{m}^{2}\right)$ & 0.0002471 & acre \\
square meter per second $\left(\mathrm{m}^{2} / \mathrm{s}\right)$ & 10.76 & square foot per second
\end{tabular}

Inch/Pound to SI

\begin{tabular}{lll}
\hline \multicolumn{1}{c}{ Multiply } & By & \multicolumn{1}{c}{ To obtain } \\
\hline cubic foot per second $\left(\mathrm{ft}^{3} / \mathrm{s}\right)$ & 0.02832 & cubic meter per second $\left(\mathrm{m}^{3} / \mathrm{s}\right)$ \\
cubic yard $\left(\mathrm{yd}^{3}\right)$ & 0.7646 & cubic meter \\
foot (ft) & 0.3048 & meter \\
inch (in.) & 2.54 & centimeter \\
gallon (gal) & 3.785 & liter \\
square inch (in $\left.{ }^{2}\right)$ & 6.452 & square centimeter \\
ton per day (ton/day) & 0.9072 & metric ton per day (tonne/d) \\
\hline
\end{tabular}

Dual units are used in this report. English units are used throughout with the exception of suspended-sediment concentration, grain size, and optical backscatter data, which are presented in milligrams per liter, millimeters, and millivolts.

Temperature in degrees Fahrenheit $\left({ }^{\circ} \mathrm{F}\right)$ may be converted to degrees Celsius $\left({ }^{\circ} \mathrm{C}\right)$ as follows:

$$
{ }^{\circ} \mathrm{C}=\left({ }^{\circ} \mathrm{F}-32\right) / 1.8
$$

Horizontal coordinate information is referenced to the North American Datum of 1927 (NAD 27). Elevation refers to distance above the National Geodetic Vertical Datum of 1929 (NGVD 29) 


\title{
Abbreviations
}

\author{
$\mathrm{ft}$, foot \\ $\mathrm{ft}^{3} / \mathrm{s}$, cubic foot per second \\ $\mathrm{ft}^{2} / \mathrm{s}$, square foot per second \\ $\mathrm{g} / \mathrm{ft} / \mathrm{s}$, gram per foot per second \\ in., inch \\ $\mathrm{m}$, meter \\ $\mu \mathrm{m}$, micrometer \\ $\mathrm{mi}$, mile \\ $\mathrm{mm}$, millimeter \\ $\mathrm{m}^{2}$, square meter \\ $\mathrm{mi}^{2}$, square mile \\ Mya, million years ago \\ phi, unit of measure used in grain size analysis \\ $r^{2}$, coefficient of determination \\ tons/day, tons per day \\ tons $/ \mathrm{mi}^{2}$, tons per square mile \\ $\mathrm{yd}^{3}$, cubic yard
}

\section{Acronyms and Symbols}

CBDA, California Bay-Delta Authority

CBDA-ERP, California Bay-Delta Authority-Ecosystem Restoration Program

$\mathrm{D}_{84}$, the grain size representing 84 percent of the bed-surface material

EDI, equal discharge interval

EWI, equal-width increment

ERP, Ecosystem Restoration Program

g, gravitational acceleration

GCLAS, Graphical Constituent Loading Analysis System

$\mathrm{h}^{1}$, the portion of the flow depth attributed solely to skin friction

$\mathrm{H}_{2} \mathrm{O}_{2}$, hydrogen peroxide

ID, identification number

OBS, optical backscatter sensor

$\mathrm{p}$ value, the probability of error associated with accepting the predicted results as true

$P l_{\text {np }}$, nonparametric prediction interval

Q, streamflow

RMS, root mean square

SSC, suspended-sediment concentration

SSC/V, suspended-sediment concentration/voltage

SDSZ, unpublished software documentation

$U$, mean velocity

$\mathrm{U}^{*}$, bed-shear velocity

USGS, U.S. Geological Survey

UYRSP, Upper Yuba River Studies Program

WY, water year 
This page intentionally left blank. 


\title{
Use of Sediment Rating Curves and Optical Backscatter Data to Characterize Sediment Transport in the Upper Yuba River Watershed, California, 2001-03
}

\author{
By Jennifer A. Curtis, Lorraine E. Flint, Charles N. Alpers, Scott A. Wright, and Noah P. Snyder
}

\begin{abstract}
Sediment transport in the upper Yuba River watershed, California, was evaluated from October 2001 through September 2003. This report presents results of a three-year study by the U.S. Geological Survey, in cooperation with the California Ecosystem Restoration Program of the California Bay-Delta Authority and the California Resources Agency. Streamflow and suspended-sediment concentration (SSC) samples were collected at four gaging stations; however, this report focuses on sediment transport at the Middle Yuba River (11410000) and the South Yuba River (11417500) gaging stations. Seasonal suspended-sediment rating curves were developed using a group-average method and non-linear least-squares regression. Bed-load transport relations were used to develop bed-load rating curves, and bed-load measurements were collected to assess the accuracy of these curves. Annual suspended-sediment loads estimated using seasonal SSC rating curves were compared with previously published annual loads estimated using the Graphical Constituent Loading Analysis System (GCLAS). The percent difference ranged from -85 percent to +54 percent and averaged -7.5 percent. During water year 2003, optical backscatter sensors (OBS) were installed to assess event-based suspended-sediment transport. Event-based suspended-sediment loads calculated using seasonal SSC rating curves were compared with loads calculated using calibrated OBS output. The percent difference ranged from +50 percent to -369 percent and averaged -79 percent.
\end{abstract}

The estimated average annual sediment yield at the Middle Yuba River (11410000) gage (5 tons $/ \mathrm{mi}^{2}$ ) was significantly lower than that estimated at the South Yuba River (11417500) gage (14 tons $/ \mathrm{mi}^{2}$ ). In both rivers, bed load represented 1 percent or less of the total annual load throughout the project period. Suspended sediment at the Middle Yuba River (11410000) and South Yuba River (11417500) gages was typically greater than
85 percent silt and clay during water year 2003, and sand concentrations at the South Yuba River (11417500) gage were typically higher than those at the Middle Yuba River (11410000) gage for a given streamflow throughout the three year project period. Factors contributing to differences in sediment loads and grain-size distributions at the Middle Yuba River (11410000) and South Yuba River (11417500) gages include contributing drainage area, flow diversions, and deposition of bed-materialsized sediment in reservoirs upstream of the Middle Yuba River (11410000) gage. Owing to its larger drainage area, higher flows, and absence of man-made structures that restrict sediment movement in the lower basin, the South Yuba River transports a greater and coarser sediment load.

\section{Introduction}

The upper Yuba River watershed is a heavily managed basin recovering from hydraulic gold mining that occurred in the mid 1800s to early 1900s. The Upper Yuba River Studies Program (UYRSP), a component of the California Bay-Delta Authority (CBDA) Ecosystem Restoration Program (ERP), is evaluating options for introducing spring-run Chinook salmon and steelhead trout upstream of Englebright Dam, which is located in the foothills of the northwestern Sierra Nevada, California (fig. 1). This report is one product of on-going studies by the U.S. Geological Survey (USGS) (Childs and others, 2003; Flint and others, 2004; Snyder and others, 2004a, 2004b, 2004c; Curtis and others, 2005), which provide a comprehensive analysis of sediment sources, transport, and storage in the upper Yuba River watershed. The USGS is also investigating water quality in the Yuba River watershed and sediment quality in Englebright Lake, with an emphasis on mercury contamination and bioaccumulation (Alpers and others, 2004; Slotten, 2004). 

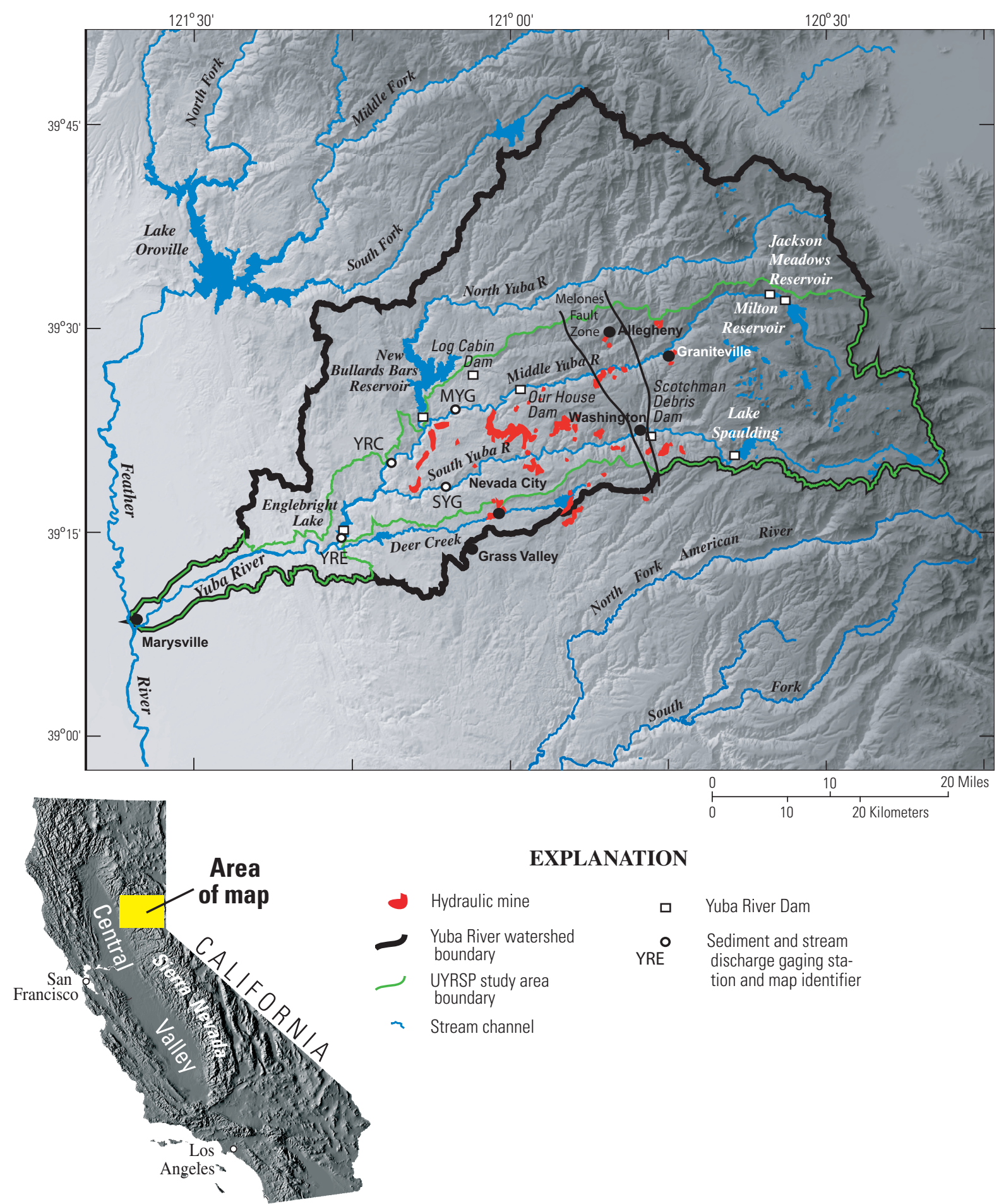

EXPLANATION

- Hydraulic mine

Yuba River watershed boundary

UYRSP study area boundary

a Stream channel

Figure 1. Location of sediment and streamflow gaging stations, study area of the Upper Yuba River Studies Program (UYRSP), and the upper Yuba River watershed, California. See table 1 for station names. 


\section{Purpose and Scope}

This study assesses sediment transport in the upper Yuba River watershed, using sediment rating curves and optical backscatter data, and along with the USGS Annual Water-Data Reports (Rockwell and others, 2001; Smithson and others, 2002; Friebel and others, 2003), provides baseline daily, annual, and event-based sediment-transport data for the upper Yuba River watershed. The sediment rating curves and OBS time-series data were used to calibrate a watershed-scale sediment transport model (Flint and others, 2004) and to assess the magnitude and duration of sediment loads that may impact the viability of long-term fish-introduction strategies (Curtis and others, 2004). The rating curves provided a means to estimate annual sediment loads by using simulated historic streamflow from 1940 to 2000 (Flint and others, 2004). The estimated historic annual sediment loads were compared to downstream annual sedimentation rates in Englebright reservoir (Snyder and others, 2004c). In addition, the rating curves were used to estimate event-based sediment transport using 15-minute streamflow data, and these estimates were compared with estimates made using optical backscatter data. Sediment loads estimated using rating curves were compared with loads estimated using GCLAS (Rockwell and others, 2001; Smithson and others, 2002; Friebel and others, 2003), but are not intended to replace the previously published daily and annual loads.

\section{Acknowledgments}

Terry Mills and Rebecca Fris (CBDA-ERP) and the California Resources Agency assisted with project funding and contract management. Denis O'Halloran (USGS-Carnelian Bay, California) and Ned Andrews (USGS-Denver, Colorado) provided insightful discussions regarding sediment transport. Alan Mlodnosky (USGS-Marina, California), Carlin Dare (USGSMenlo Park, California), Gary Schneider (USGS-Menlo Park, California), and Ryan Wooley (USGS-Menlo Park, California) completed the suspended-sediment-concentration and grainsize analyses. Sarah Yarnell (University of California, Davis), Michael Hunerlach (USGS-Sacramento, California), Donna Knifong (USGS-Sacramento, California), Michael Judd, and David Sparks assisted with the Shady Creek bed-load measurements.

\section{Study Area}

The Yuba River, a tributary to the Feather River in northern California, drains approximately 1,344 $\mathrm{mi}^{2}$ along the western slope of the Sierra Nevada (fig. 1). The study area is within the upper Yuba River watershed, which encompasses the area upstream of Englebright Lake and includes three tributaries: the North Yuba River, the Middle Yuba River, and the South Yuba River. A significant part of the Yuba River sediment load is deposited in New Bullards Bar Reservoir (Brown and Thorpe, 1947; Dendy and Champion, 1978), in Englebright Lake (Childs and others, 2003; Snyder and others, 2004b; Snyder and others, 2004c), and behind Log Cabin Dam and Our House Dam (Yuba County Water Agency, 1989). Because only wash-load-sized material (the finer part of the sediment load carried by streamflow) bypasses New Bullards Bar Reservoir on the North Yuba River, the focus of this study was on sediment transport solely within the Middle Yuba and South Yuba Rivers.

The upper Yuba River tributaries (North Yuba, Middle Yuba, and South Yuba Rivers) are steep, mountain drainages that flow through narrow, deeply incised canyons alternating between bedrock and alluvial reaches. Alluvial reaches store considerable volumes of sediment in the channel bed, active bars, and infrequent well-vegetated floodplains and terraces (Curtis and others, 2005). Bedrock reaches have minimal channel storage, although patchy alluvium may be found in deep pools or behind bedrock constrictions or large boulders. Large volumes of sediment, derived from upstream hydraulic-mining activities, are currently stored in several upland tributaries that flow into the Middle Yuba and South Yuba Rivers.

\section{Climate, Precipitation, and Runoff}

The study area has a mediterranean climate with hot, dry summers and cool, wet winters. Beginning in November, Pacific frontal systems bring winter precipitation into northern California, and approximately 85 percent of the annual precipitation falls between November and April. Mean annual precipitation ranges from $20 \mathrm{in}$. at Marysville at the western downstream end of the watershed (fig. 1) to more than $59 \mathrm{in.}$ at the eastern margin of the watershed along the Sierra Nevada crest (Western Regional Climate Center, accessed November 8, 2004). Total precipitation at Englebright Lake was 24 in., 32 in., and 37 in. (California Data Exchange Center, accessed November 8 , 2004) during water years 2001, 2002, and 2003, respectively. Average annual precipitation at Englebright Lake is 33 in.; therefore, water year 2001 was a dry year, 2002 was below average, and 2003 was above average. 


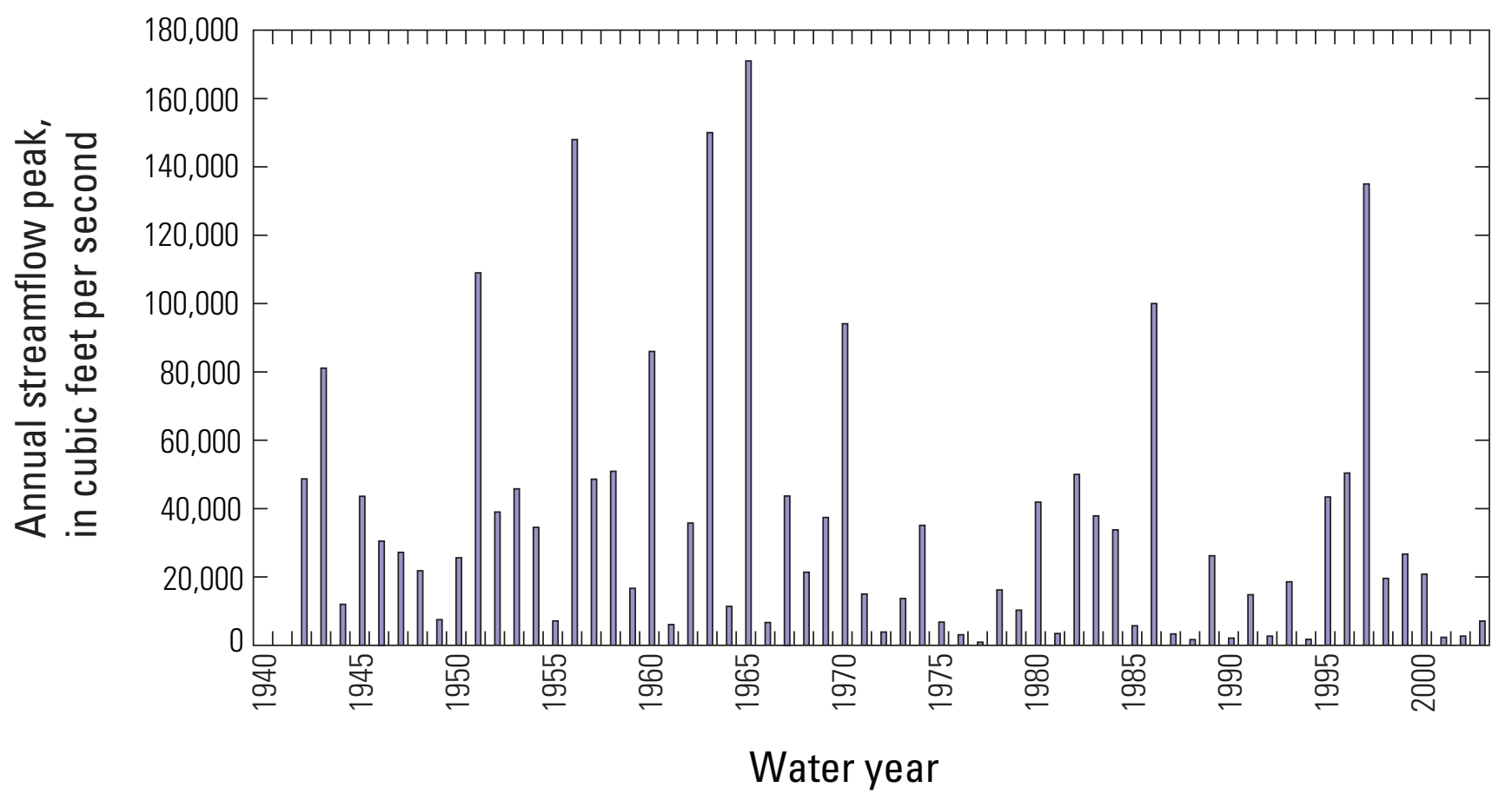

Figure 2. Annual peak streamflows measured from 1942 to 2003 for the gaging station on the Yuba River below Englebright Dam (YRE, 11418000) in the upper Yuba River watershed, California. See table 1 for station name and location. Data source: http://nwis.waterdata.usgs.gov/, accessed November 8, 2004.

Runoff in the study area is produced by winter storms from the Pacific, spring snowmelt, and occasional convective storms generated in the late summer or early autumn by subtropical air masses from the Gulf of Mexico (Kattleman, 1996). Peak flows can be as much as three orders of magnitude greater than base flows and annual runoff volumes can be as much as seven times greater in extremely wet years than those in critically dry years. Elevations between 4,000 to $6,000 \mathrm{ft}$ in the study basin are susceptible to rain-on-snow events (California Department of Water Resources, 1966); these events have the greatest magnitude, duration, and ability to mobilize sediment. Notable runoff events (peak streamflows greater than 100,000 $\mathrm{ft}^{3} / \mathrm{s}$ ) at the Yuba River below Englebright Dam (11418000) occurred during water years (WY) 1951, 1956, 1963, 1965, 1986, and 1997 (fig. 2). The timing of runoff throughout the study area is controlled to a considerable extent by a system of reservoirs and diversions (fig. 3).

\section{Geologic Setting}

Bedrock in the study area is composed primarily of Paleozoic metasediments and metavolcanics (ShooFly and
Calaveras Formations), Paleozoic and Mesozoic plutonic rocks (Bowman Lake batholith, Sierra Nevada batholith, and Yuba River pluton), and a Mesozoic ophiolite (Smartville Complex). Ridge tops typically are capped by Eocene auriferous sediments deposited by the ancestral Yuba River, Miocene-Pliocene rhyolites, rhyolitic sediments (Valley Springs Formation), and andesitic lahars (Mehrten Formation) (Saucedo and Wagner, 1992).

Cenozoic geologic history includes uplift and tilting of the Sierra Nevada and at least two Late Quaternary glaciations (Lindgren, 1911; Bateman and Wahrhaftig, 1966; Christensen, 1966; James and others, 2002). Uplift and tilting reorganized drainage networks and initiated a period of sustained channel incision. The modern Yuba River system began incising approximately 5 Mya (million years ago) (Wakabayashi and Sawyer, 2001). The easternmost portion of the basin was glaciated during the Quaternary, and the Middle Yuba River and South Yuba River drainages are mantled by till and glacial outwash deposited by Late Quaternary valley glaciers (James and others, 2002). 


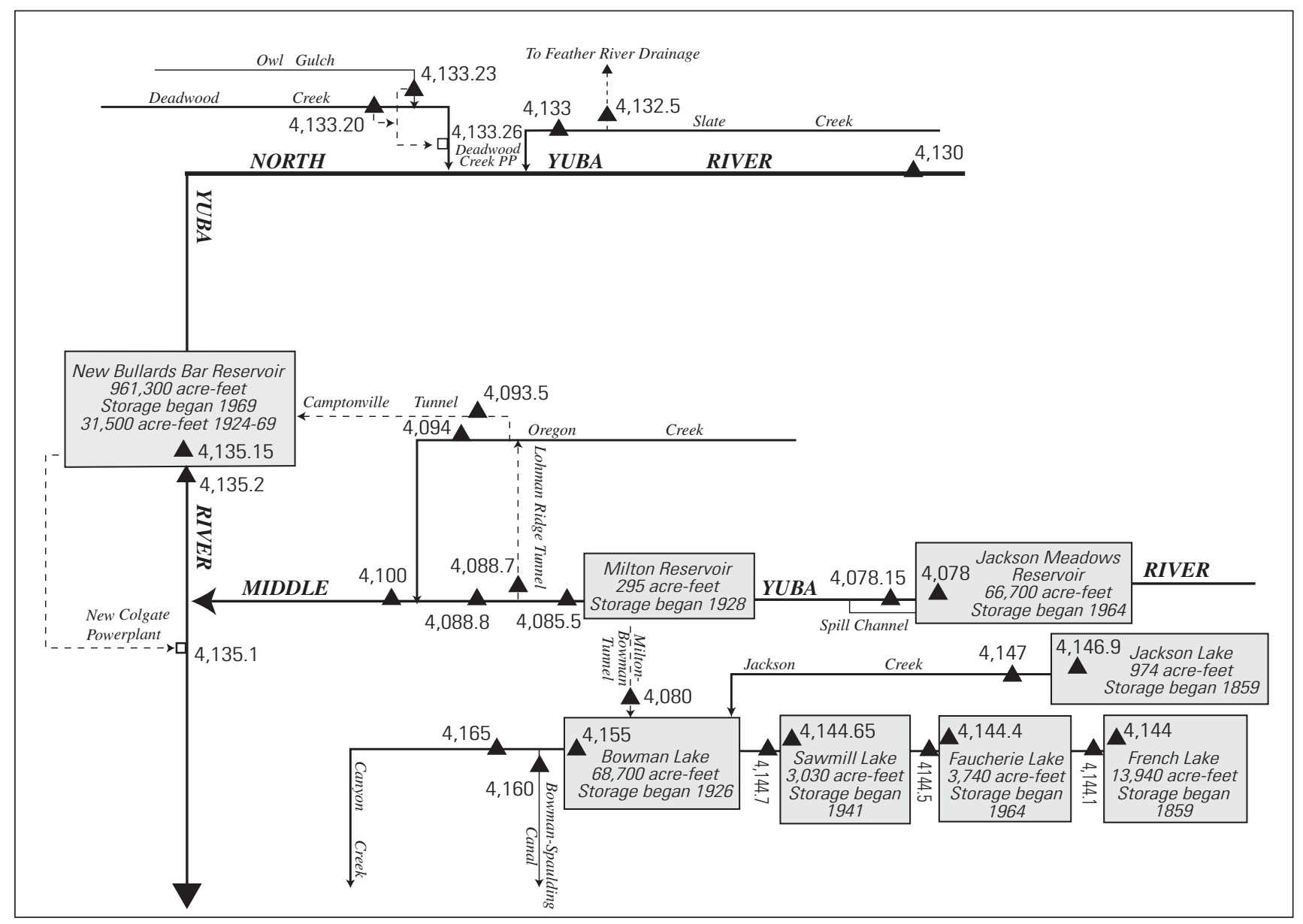

EXPLANATION

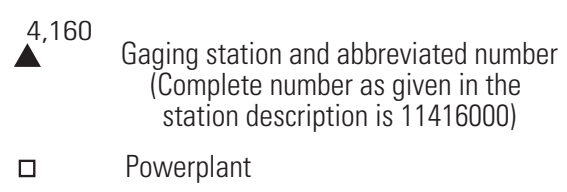

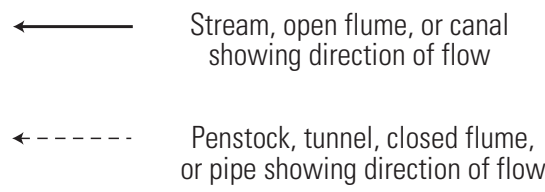

Figure 3. Stream diversions and reservoir storage in the upper Yuba River watershed, California. Source: Rockwell and others, 2001 http://water. usgs.gov/pubs/wdr/WDR-CA-01-4/). 


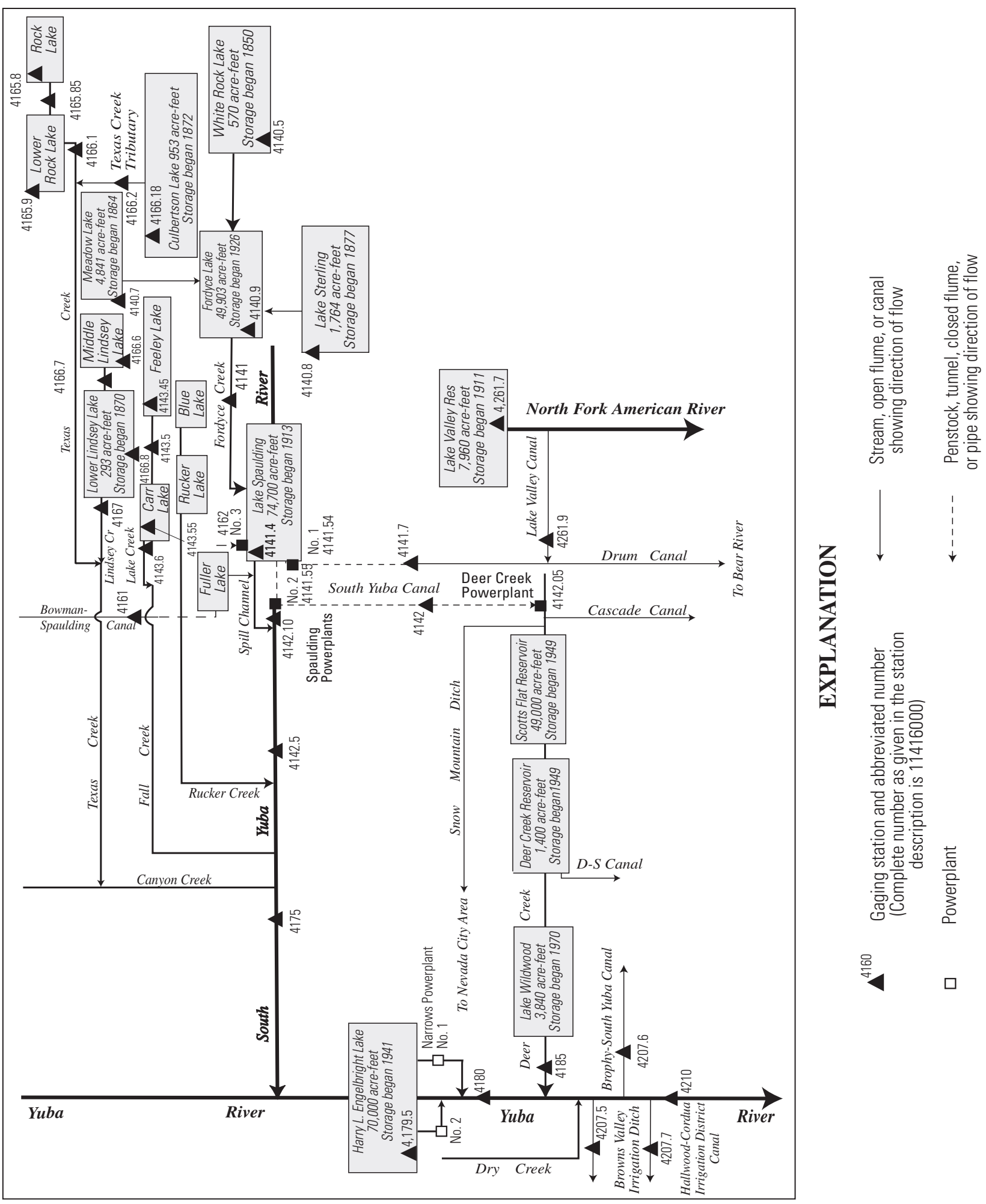

Figure 3. Continued. 


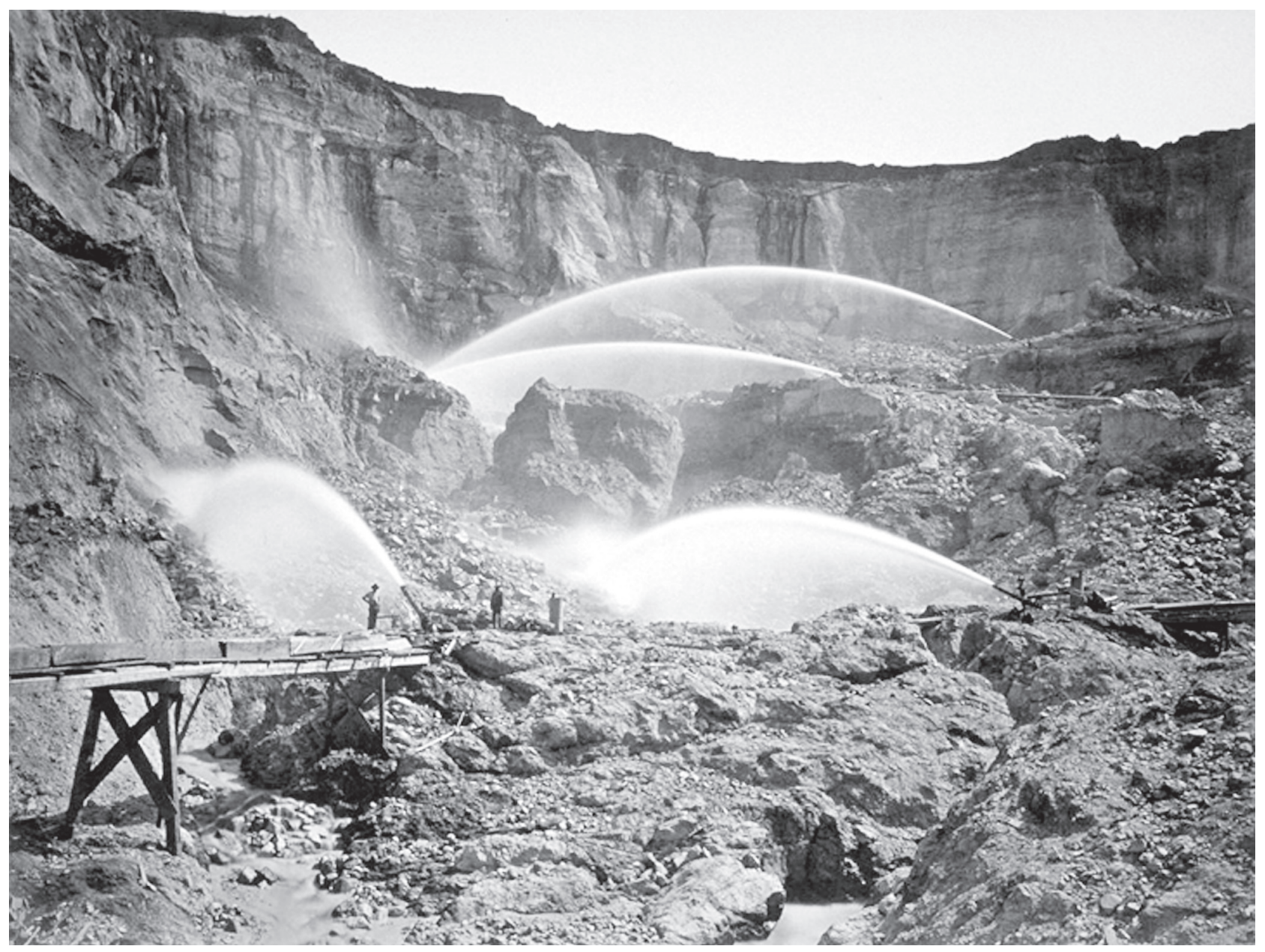

Figure 4. Hydraulic mining at Malakoff Diggings (circa 1876), located in the South Yuba River watershed, California. Historic photograph taken by Carleton E. Watkins, Hearst Mining Collection, Bancroft Library, University of California at Berkeley.

\section{Hydraulic Mining History}

Gold-bearing sediments, deposited by the ancestral Yuba River (Whitney, 1880; Lindgren, 1911; Yeend, 1974), were hydraulically mined during the California Gold Rush of the midto-late 1800 s and again during a protracted period of licensed mining in the early 1900s. Hydraulic-mining involved directing high-pressure water cannons at exposures of Eocene gravel (fig. 4) and washing the excavated sediment slurry through mercuryladen sluice boxes (Bowie, 1905; May, 1970; Averill, 1976; Alpers and others, 2005). Hydraulic mine tailings were conveyed into adjacent watercourses (Alpers and Hunerlach, 2000; Alpers and others, 2005), leading to dramatic increases in sediment loads and severe aggradation (Hall, 1880; Turner, 1891; Gilbert, 1917). Gilbert (1917) estimated that hydraulic-mining contributed approximately 682 million $\mathrm{yd}^{3}$ of sediment to Yuba River channels. In 1884, owing to downstream environmental effects, large-scale hydraulic-mining was ended by court injunction (Sawyer Decision). Licensed hydraulic-mining began in 1893 (Camenetti Act) and continued in the Yuba River basin until the 1930s. Presently, the abandoned hydraulic mine pits experience chronic hillslope erosion (Yuan, 1979) and, therefore, are considered a significant sediment source to upper Yuba River channels (Curtis and others, 2005).

Extensive remobilization of stored hydraulic-mining sediment began as early as 1861 when severe winter storms delivered substantial volumes of sediment to the Central Valley. In 1941, the California Debris Commission built Englebright Dam to trap hydraulic-mining sediment mobilized within the upper Yuba River watershed. The majority of Middle Yuba River and South Yuba River mainstem channels have since recovered their pre-mining bed elevations, but significant volumes of hydraulic mining sediment remain stored in wide mainstem reaches and in smaller upland tributaries of these two rivers. Previous studies of the Yuba River and adjacent watersheds (Wildman, 1981; James, 1993; Curtis, 1999) indicate that these smaller tributaries are asymptotically incising toward pre-mining channel-bed elevations; therefore, remobilization of hydraulic-mining sediment continues to affect sediment yields from impacted basins. 


\section{Methods of Data Collection and Analysis}

Streamflow measurements and suspended-sediment samples were collected at four upper Yuba River gaging stations (fig. 1; table 1): Middle Yuba River near North San Juan (USGS station ID 11410000), South Yuba River at Jones Bar near Grass Valley (USGS station ID 11417500), Yuba River below New Colgate Powerplant near French Corral (USGS station ID 11413700), and Yuba River below Englebright Dam near Smartville (USGS station ID 11418000). The Middle Yuba River (11410000) gage operated from 1911 to 1941 and from 2001 to present. The South Yuba River (11417500) gage operated from 1940 to 1948 and from 1959 to present. The Yuba River below New Colgate Powerplant (11413700) gage was established in 2001 but was abandoned in 2003 owing to a poor gaging record. The Yuba River below Englebright Dam (11418000) gage operated continually from 1941 to present. Daily records of streamflow and suspended-sediment loads for water years 2001, 2002, and 2003 are published in USGS Annual WaterData Reports (Rockwell and others, 2001; Smithson and others, 2002; Friebel and others, 2003). Annual streamflow peaks as well as daily and 15-minute streamflow data are available at http://waterdata.usgs.gov/nwis/.

\section{Suspended Sediment}

\section{Sampling and Concentration Analysis}

Depth-integrated, single vertical and multi-vertical suspended-sediment samples were collected at upper Yuba River gaging stations following standard USGS procedures (Edwards and Glysson, 1999). Samples were collected at four gaging stations (Middle Yuba River, 11410000; South Yuba River, 11417500; Yuba River below New Colgate Powerplant, 11413700; and Yuba River below Englebright, 11418000) during water years 2001 and 2002 and at three gaging stations (11410000, 11417500, 11418000) during water year 2003. Suspended-sediment concentrations for all samples were measured at the USGS sediment laboratory in Marina, California, using methods described by Guy (1969). During water years 2001 through 2003, single vertical samples were collected 1 to 7 days per week, depending on hydrologic conditions, with increased frequency of sampling during periods of higher streamflow. Beginning in water year 2002, two sequential single vertical samples were collected during each visit and analyzed separately for concentration. Multi-vertical cross-section samples, collected approximately monthly, were used to determine a coefficient to account for discrepancies between the mean suspended-sediment concentration of the single vertical samples and that of the entire cross section. Multi-vertical sampling consisted of collecting a single vertical sample, a set of 12 equal-discharge-increment (EDI) samples across the channel, followed by another single vertical sample. The concentrations of these 14 samples were analyzed separately. Comparisons of the single vertical samples with the cross-section samples indicate that flows generally were well-mixed with respect to sediment at all four gaging stations. The average difference between concurrent single vertical and EDI samples was 13 percent. Although streamflow samples for suspended-sediment analysis were collected primarily during low and moderate flows, we infer the mean discharge-weighted suspended-sediment concentration of all single vertical samples are representative of the channel cross section, thus making use of a coefficient unnecessary.

\section{Storm Sampling}

Storm sampling at the Middle Yuba River (11410000) and South Yuba River (11417500) gages enabled characterization of changes in suspended-sediment concentrations and grainsize distributions over the duration of four discrete storm hydrographs during water year 2003. Storms were chosen to represent four different times during the wet season (November, December, February, and March). The November storm was the first runoff event of the wet season and the other three runoff events were typical winter storms. The protocol for storm sampling included collection of single vertical suspended-sediment samples at 1- to 2-hour intervals during daylight hours and collection of at least one sequential pair of grain-size samples per day, which enabled characterization of the rising limb, peak, and falling limb of each storm hydrograph.

\section{Grain-Size Analysis of Suspended Sediment}

Replicate sets of suspended-sediment samples were collected from three of the upper Yuba River gaging stations (Middle Yuba River, 11410000; South Yuba River, 11417500; and Yuba River below Englebright Dam, 11418000) during storm sampling for detailed grain-size analyses. Two sequential sets of depth integrated, multi-vertical, equal-discharge-interval (EDI) suspended-sediment samples were collected at five centroids across the channel cross section. One set of samples was analyzed at the USGS sediment laboratory in Marina, California. A second set of samples was analyzed at the USGS Coastal and Marine Geology laboratory in Menlo Park, California. Both laboratories used standard sieve methods described by Guy (1969) for grain size analysis of the sand-sized fraction and results were similar. However, sample preparation and the results for sediment smaller than $0.063 \mathrm{~mm}$ differed between the two laboratories. The Marina Laboratory removed organic material (using $\mathrm{H}_{2} \mathrm{O}_{2}$ [hydrogen peroxide]) only from the sand-sized fraction, and the less than $0.63-\mathrm{mm}$ sized fraction is reported. The Menlo Park Laboratory removed the organic material from the full sample and completed detailed analyses of the less than 0.063-mm fraction. Both laboratories used hexametaphosphate to disperse sediment smaller than $0.063 \mathrm{~mm}$, but the Menlo 
Table 1. Summary of streamflow and suspended-sediment measurements for four sites in the Upper Yuba River watershed, California, during water years 2001, 2002, and 2003.

[See figure 1 for station locations. Latitude and longitude are referenced to the North American Datum of 1927 (NAD 27). Elevation is referenced to the National Geodetic Vertical Datum of 1929 (NGVD 29). EDI, equal-discharge interval; N, number of samples. mi ${ }^{2}$, square miles; $\mathrm{ft}$, feet; $\mathrm{ft}^{3} / \mathrm{s}$, cubic feet per second. - , gage discontinued because of poor rating]

\begin{tabular}{|c|c|c|c|c|c|c|c|c|c|}
\hline \multirow{3}{*}{$\begin{array}{c}\text { Map } \\
\text { identifier }\end{array}$} & \multirow{3}{*}{$\begin{array}{l}\text { Station } \\
\text { identifier }\end{array}$} & \multirow{3}{*}{ Gage name } & & & \multirow{3}{*}{$\begin{array}{l}\text { Drainage } \\
\text { area } \\
\left(\mathrm{mi}^{2}\right)\end{array}$} & \multirow{3}{*}{$\begin{array}{l}\text { Elevation } \\
\quad(\mathrm{ft})\end{array}$} & \multicolumn{3}{|c|}{ Water year 2001} \\
\hline & & & \multicolumn{2}{|c|}{ Location } & & & \multirow{2}{*}{$\begin{array}{l}\text { Suspended- } \\
\text { sediment } \\
\text { EDI samples } \\
\text { (N) }{ }^{1}\end{array}$} & \multirow{2}{*}{$\begin{array}{l}\text { Minimun daily } \\
\text { streamflow } \\
\left(\mathrm{ft}^{3} / \mathrm{s}\right)\end{array}$} & \multirow{2}{*}{$\begin{array}{l}\text { Maximum } \\
\text { daily } \\
\text { streamflow } \\
\left(\mathrm{ft}^{3} / \mathrm{s}\right)\end{array}$} \\
\hline & & & Latitude & Longitude & & & & & \\
\hline MYG & 11410000 & $\begin{array}{l}\text { Middle Yuba River near } \\
\text { North San Juan, CA }\end{array}$ & $39^{\circ} 23^{\prime} 39^{\prime \prime}$ & $121^{\circ} 05^{\prime} 02^{\prime \prime}$ & 198 & 1,450 & 196 & 27 & 150 \\
\hline SYG & 11417500 & $\begin{array}{c}\text { South Yuba River at } \\
\text { Jones Bar near Grass } \\
\text { Valley, CA }\end{array}$ & $39^{\circ} 17^{\prime} 32^{\prime \prime}$ & $121^{\circ} 06^{\prime} 13^{\prime \prime}$ & 308 & 1,600 & 194 & 29 & 1,020 \\
\hline YRC & 11413700 & $\begin{array}{c}\text { Yuba River below New } \\
\text { Colgate Powerplant } \\
\text { near French Corral, } \\
\text { CA }\end{array}$ & $39^{\circ} 19^{\prime} 50^{\prime \prime}$ & $121^{\circ} 11^{\prime} 34^{\prime \prime}$ & 717 & 550 & 98 & 41 & 3,080 \\
\hline YRE & 11418000 & $\begin{array}{l}\text { Yuba River below } \\
\text { Englebright Dam near } \\
\text { Smartville, CA }\end{array}$ & $39^{\circ} 14^{\prime} 07^{\prime \prime}$ & $121^{\circ} 16^{\prime} 23^{\prime \prime}$ & 1,108 & 279 & 62 & 598 & 2,280 \\
\hline
\end{tabular}

\begin{tabular}{|c|c|c|c|c|c|c|c|}
\hline \multirow[b]{2}{*}{$\begin{array}{c}\text { Map } \\
\text { identifier }\end{array}$} & \multirow[b]{2}{*}{$\begin{array}{l}\text { Station } \\
\text { identifier }\end{array}$} & \multicolumn{3}{|c|}{ Water year 2002} & \multicolumn{3}{|c|}{ Water year 2003} \\
\hline & & $\begin{array}{c}\text { Suspended- } \\
\text { sediment } \\
\text { EDI samples } \\
(\mathrm{N})^{2}\end{array}$ & $\begin{array}{c}\text { Minimum } \\
\text { daily } \\
\text { streamflow } \\
\left(\mathrm{ft}^{3} / \mathrm{s}\right)\end{array}$ & $\begin{array}{c}\text { Maximum } \\
\text { daily } \\
\text { streamflow } \\
\left(\mathrm{ft}^{3} / \mathrm{s}\right)\end{array}$ & $\begin{array}{c}\text { Suspended- } \\
\text { sediment } \\
\text { EDI samples } \\
(\mathrm{N})^{3}\end{array}$ & $\begin{array}{c}\text { Minimum } \\
\text { daily } \\
\text { streamflow } \\
\left(\mathrm{ft}^{3} / \mathbf{s}\right)\end{array}$ & $\begin{array}{c}\text { Maximum } \\
\text { daily } \\
\text { streamflow } \\
\left(\mathbf{f t}^{3} / \mathbf{s}\right)\end{array}$ \\
\hline MYG & 11410000 & 150 & 28 & 906 & 152 & 29 & 1,390 \\
\hline SYG & 11417500 & 154 & 30 & 1,750 & 143 & 41 & 2,990 \\
\hline YRC & 11413700 & 106 & 43 & 3,050 & - & - & - \\
\hline YRE & 11418000 & 36 & 573 & 4,170 & 33 & 629 & 6,940 \\
\hline
\end{tabular}

'Sediment sample collection period for MYG and SYG, November 3, 2000, to September 30, 2001; for YRC, January 10, 2002, to September 30, 2001; and for YRE, January 13, 2001, to September 30, 2001. '2Sediment sample collection period October 1, 2001, to June 30, 2001. ${ }^{3}$ Sediment sample collection period November 1, 2002, to May 31, 2003. 
Park Laboratory used ultrasound dispersal techniques also to further disperse the less than 0.063 -mm sized fraction.

At the Menlo Park Laboratory, sediment smaller than $0.063 \mathrm{~mm}$ was analyzed using a Coulter LS 100Q laser-diffraction particle-size analyzer. Each sample was run through the Coulter instrument three times; the reported size distribution is the average of the three runs. Grain-size statistics were calculated using software (SDSZ; McHendrie and Madison, 1989, unpublished software documentation) that interpolates the size distribution at 0.5 phi increments.

\section{Suspended-Sediment Rating Curves}

Suspended-sediment transport is governed by sediment supply and the capacity of a stream to transport the available sediment. In some cases, such as alluvial rivers, streamflow and sediment supply tend to vary together such that the suspended-sediment concentration at a given location can be characterized using sediment rating curves, which relate transport of suspended sediment to streamflow. For cases when streamflow and sediment supply do not vary together, suspended-sediment concentration cannot be characterized by streamflow alone. In these cases, separate sediment rating curves must be developed for different supply conditions. Varying supply conditions occur primarily as a function of season in the Middle Yuba and South Yuba Rivers and justify development of separate suspended-sediment rating curves, as described below.

The relation between suspended-sediment concentration and streamflow at the four upper Yuba River gaging stations is shown in figure 5 A-D (also see Appendix 1 for complete data set shown in figure $5 A-D$ ). Significant scatter in the concentration-streamflow relations indicates differences in sediment supply conditions attributable to seasonal and natural variability. Lack of precipitation during summer and fall months results in low base streamflow (for example, $25 \mathrm{ft}^{3} / \mathrm{s}$ ), which allows fine sediment to settle and accumulate in deep pools. During the first significant fall runoff event, called the first flush, significant amounts of easily transportable fine sediment are scoured from pools and eroded from hillslopes. Although hillslope erosion rates throughout the upper Yuba River watershed are relatively low compared with erosion rates for rapidly eroding hillslopes such as those in the Pacific Northwest, rilling, gullying, and mass wasting occur throughout the study area (Curtis and others, 2005).

Seasonal variability in the supply of suspended sediment is clearly evident when peak streamflow and associated suspended-sediment concentrations for first flush and snow melt conditions are compared. Samples collected from the upper Yuba River during the first flush generally have high suspended-sediment concentrations with low associated streamflow. For example, peak suspended-sediment concentrations in November 2002, and associated streamflow (shown in parentheses), were $134 \mathrm{mg} / \mathrm{L}\left(280 \mathrm{ft}^{3} / \mathrm{s}\right)$ at the South Yuba River (11417500) gage and $100 \mathrm{mg} / \mathrm{L}\left(58 \mathrm{ft}^{3} / \mathrm{s}\right)$ at the Middle Yuba River (11410000) gage (concentrations are averages for duplicate samples listed in Appendix la,b). Conversely, significant runoff from snowmelt occurs during the spring, resulting in high baseflows. Samples collected during snowmelt conditions have low suspended-sediment concentrations but high associated streamflow, indicating supply-limited conditions. For example, suspended-sediment concentrations during peak snowmelt conditions in May 2003, and associated streamflow, were $22 \mathrm{mg} / \mathrm{L}\left(1,930 \mathrm{ft}^{3} / \mathrm{s}\right)$ at the South Yuba River (11417500) gage and $7 \mathrm{mg} / \mathrm{L}\left(260 \mathrm{ft}^{3} / \mathrm{s}\right)$ at the Middle Yuba River (11410000) gage (concentrations are averages for duplicate samples listed in Appendix la,b).

Natural variability also influences the concentrationstreamflow relation owing to processes such as depletion or rejuvenation of suspendable-sized sediment or to spatial variations in precipitation intensity and runoff throughout tributary and mainstem channel networks. Variability in the concentration-streamflow relation may also be caused by errors during sample collection and by corruption of samples during shipping or laboratory analyses.

Although there are numerous methods for developing rating curves, the most commonly used function for sediment rating curves is a power function,

$$
\mathrm{SSC}=\mathrm{a} \mathrm{Q}^{\mathrm{b}},
$$

where SSC is suspended-sediment concentration $(\mathrm{mg} / \mathrm{L})$, Q is streamflow $\left(\mathrm{ft}^{3} / \mathrm{s}\right)$, and $\mathrm{a}$ and $\mathrm{b}$ are regression coefficients (Walling, 1977; Asselman, 2000; Horowitz, 2002). Power functions were defined and regression coefficients were fit using non-linear, least-squares regression. Suspended-sediment concentrations at the Yuba River below New Colgate Powerplant (11413700) (fig. 5C) and Yuba River below Englebright Dam (11418000) (fig. 5D) gaging stations are influenced by management of New Bullards Bar Reservoir and Englebright Lake. Because there are no systematic relations between suspended-sediment concentrations and streamflow at the Yuba River below New Colgate Powerplant (11413700) and Yuba River below Englebright Dam (11418000) gaging stations, regression analyses were completed only on samples collected at the Middle Yuba River (11410000) (fig. 5A) and South Yuba River (11417500) (fig. 5B) gages, which have significant scatter but show a general increase in suspended-sediment concentration with increasing streamflow.

Most of the suspended-sediment samples were collected under low to moderate streamflow conditions (fig. 5(5)); thus, regression analyses on these data are strongly influenced by the large number of measurements made during low streamflow conditions. The low-streamflow bias was removed from these data using a group average method, which results in a better defined slope for the upper end of the rating curve (Glysson, 1987). Removal of bias is an extremely important consideration because a slight error in the slope of the upper end of a sediment rating curve can generate significant error in predictions of suspended-sediment concentration, and may result in considerable error in calculations of sediment load. 


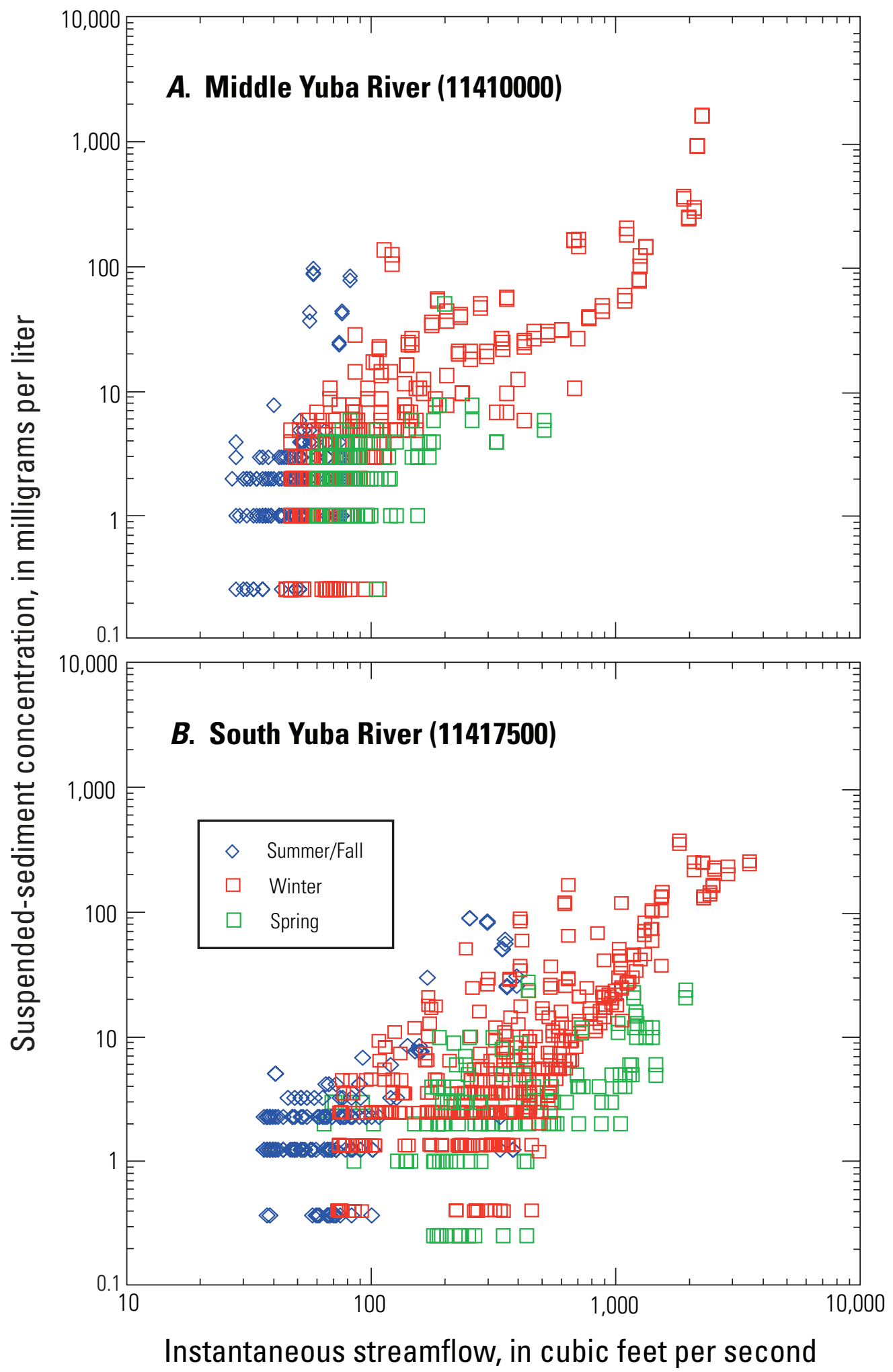

Figure 5. Relation of suspended-sediment concentration to instantaneous streamflow by season for the four gaging stations in the upper Yuba River watershed, California. A, Middle Yuba River (11410000). B, South Yuba River (11417500). C, Yuba River below New Colgate Powerplant (11413700). D, Yuba River below Englebright Dam (11418000). 


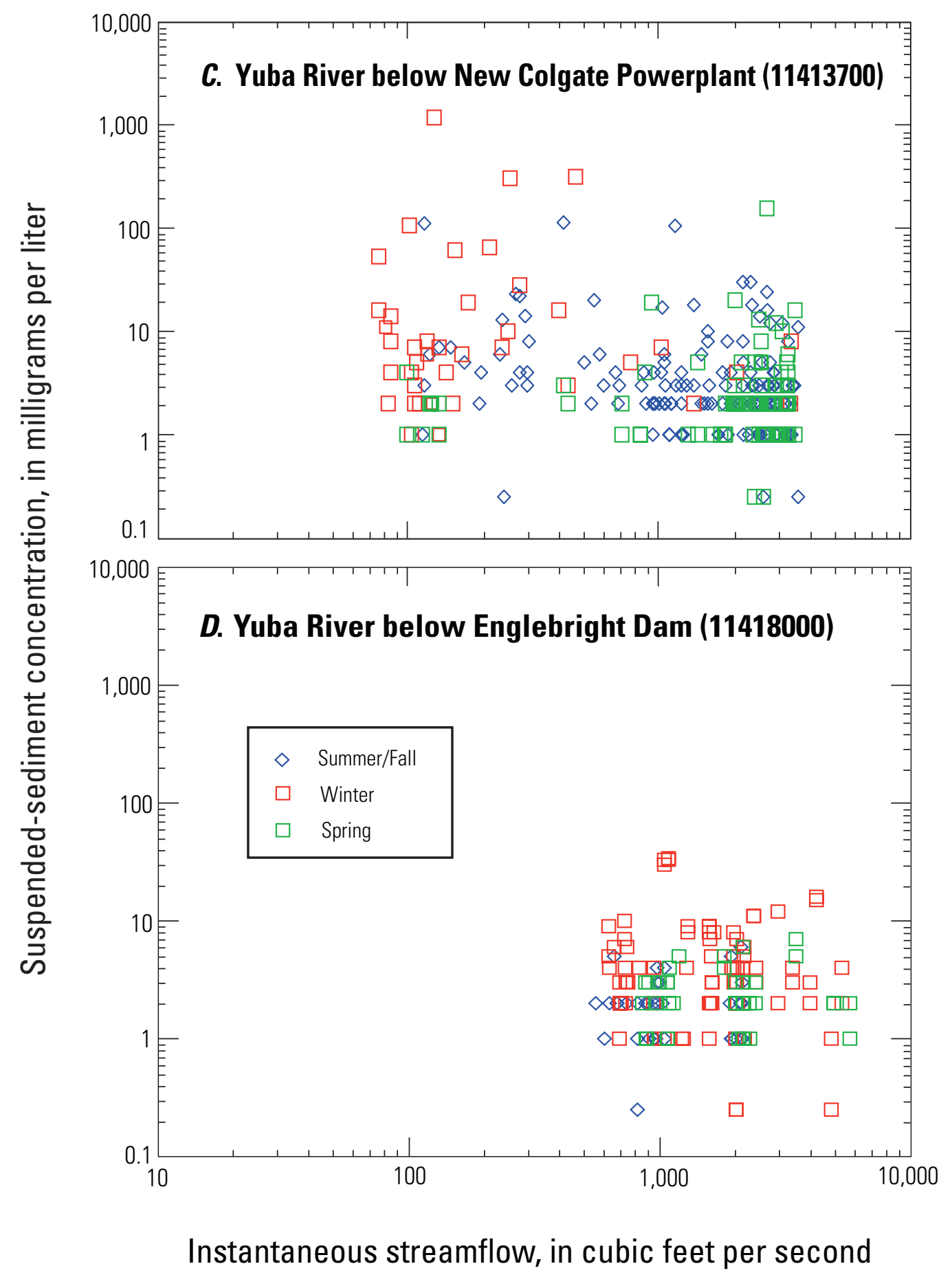

Figure 5. Continued. 
Seasonal variability dramatically influences sediment supply and transport in the upper Yuba River watershed. A single suspended-sediment concentration rating curve that represents average conditions cannot represent these varying conditions. Therefore, a series of group-average sediment rating curves were established for the Middle Yuba River (11410000) and South Yuba River (11417500) gages that describe average (all data), summer/fall, first flush, winter, and spring snowmelt conditions. Prior to regression analysis, the arithmetic mean of suspended-sediment concentration was determined for several small ranges of Q, and an outlier threshold was established whereby suspended-sediment concentration values outside two standard deviations were excluded from the analysis. This improved the skewness of the data set and resulted in an approximate normal distribution. The average suspended-sediment concentration was plotted against the associated average streamflow value for each streamflow bin. Both variables were transformed to log 10 and a power function was fit through the group average data using non-linear least squares regression. The accuracy of the suspended-sediment rating curves was assessed using summary statistics and 95-percent confidence bounds.

\section{Optical Backscatter}

Schoellhamer and Wright (2003) demonstrated that optical backscatter sensors (OBS) can be used to predict suspended-sediment concentration in rivers if particle size and sediment color remain fairly constant. The sensors, developed and tested by Downing and others (1981), emit infrared light that is reflected by suspended particles in the water column. A series of photodiodes positioned around the emitter of the OBS detects any backscatter, and then an empirical calibration is used to convert the output voltage of the sensor into a suspendedsediment concentration. Calibration of the output voltage to suspended-sediment concentration can vary significantly with particle size and color (Conner and De Visser, 1992; Levesque and Schoellhamer, 1995; Sutherland and others, 2000) and biofouling can result in significant loss of data. Therefore, optical sensors must be cleaned regularly and calibrated using field data on a site-specific basis to determine if the effects of particle size and color influence sensor calibration for a given location.

Continuously recording OBSs were installed at the Middle Yuba River (11410000) and South Yuba River (11417500) gages to provide a 15-minute time series record of suspended-sediment concentration. The sensors were calibrated using depthintegrated, single vertical suspended-sediment samples that were analyzed for suspended-sediment concentration and percent fine-grained sediment (less than $0.063 \mathrm{~mm}$ ) to assess the effects of grain size on the OBS output voltages. Because the OBS data can display non-constant variance, a linear calibration equation was determined using a robust, nonparametric, repeated median method originally developed for OBSs deployed in San Francisco Bay (Buchanan and Ruhl, 2000, 2001, 2002; Buchanan and Ganju, 2003, 2004). In addition, a prediction interval and a 95-percent confidence interval were calculated for each calibration equation to assess the goodness-of-fit.

The repeated median method (Siegel, 1982) calculates slope in a two-part process. First, for each point $(X, Y)$, the median of all possible "point $i$ " to "point $j$ " slopes is calculated

$$
\beta_{\mathrm{i}}=\operatorname{median} \frac{\left(Y_{j}-Y_{i}\right)}{\left(X_{j}-X_{i}\right)}(\text { for all } j \neq i)
$$

The calibration slope is calculated as the median of $\beta_{i}$

$$
\text { slope }=\hat{\beta}_{1}=\operatorname{median}\left(\beta_{\mathrm{i}}\right)
$$

The calibration intercept is calculated as the median of all possible intercepts using the calibration slope

$$
\text { intercept }=\hat{\beta}_{1}=\operatorname{median}\left(Y_{\mathrm{i}}-\hat{\beta}_{1} X_{\mathrm{i}}\right)
$$

The final linear calibration equation is

$$
Y=\hat{\beta}_{1} X+\hat{\beta}_{0}
$$

The nonparametric prediction interval $\left(P I_{n p}\right)$ (Helsel and Hirsch, 1992, p. 76) contains one standard deviation (68.26 percent) of the calibration data set and represents essentially the same error prediction limits as the root mean square (RMS) error of prediction in ordinary least-squared regression. However, the $P I_{n p}$, unlike the RMS error of prediction, frequently is not symmetrical about the regression line. Asymmetry about the regression line is a result of the distribution of the data set; thus, the $P I_{n p}$, may be reported as +9 to $-16 \mathrm{mg} / \mathrm{L}$. The $P I_{n p}$ is calculated by computing and sorting, from least to greatest, the residuals for each point. Then, based on the sorted list of residuals,

$$
P I_{n p}=\hat{Y}_{(\alpha / 2)(n+1)} \text { to } \hat{Y}_{(1-\alpha / 2)(n+1)}
$$

$\hat{Y}$ is the residual value, $\mathrm{n}$ is the number of data points, and $\alpha$ is the confidence level of 0.6826 .

To calculate the confidence interval, all possible point-topoint slopes are sorted in ascending order. On the basis of the confidence interval desired, 95 percent for the purposes of this report, the ranks of the upper and lower bounds are calculated as follows:

$$
\begin{aligned}
R u & =\frac{\frac{n(n-1)}{2}+1.96 \sqrt{\frac{n(n-1)(2 n+5)}{18}}}{2}+1 \\
R l & =\frac{\frac{n(n-1)}{2}-1.96 \sqrt{\frac{n(n-1)(2 n+5)}{18}}}{2}
\end{aligned}
$$

where $R u$ is the rank of the upper bound slope, $R l$ is the rank of the lower bound slope, and $n$ is the number of samples. To establish the 95-percent confidence interval, the ranks calculated above are rounded to the nearest integer and the slope associated with each rank in the sorted list is identified. 


\section{Bed Load}

\section{Bed Material Grain-Size Analysis}

For the purpose of developing bed-load rating curves, bed-surface samples were collected at Middle Yuba River (11410000) and South Yuba River (11417500) gages and at three locations along Shady Creek (figs. 1, 6). Pebble counts, made using the method described by Wolman (1954), were used to determine the surface grain-size distribution at the Shady Creek sites, whereas volumetric bed-material samples, collected using methods outlined by Milhous (1973), were used to determine the surface grain-size distribution at Middle Yuba River (11410000) and South Yuba River (11417500) gages.

Volumetric bed-material samples required excavation of the largest particle exposed on the channel bed. Although there were boulder-sized particles (greater than $256 \mathrm{~mm}$ ) on the channel bed, only particles less than or equal to $128 \mathrm{~mm}$ were collected because particles larger than this could not easily be measured. Bed material was sampled volumetrically from a $0.25-\mathrm{m}^{2}$ area to a level corresponding roughly to the bottom of the hole that was created when the largest particle was removed. Because small samples are systematically biased toward finegrained sediment (Ferguson and Paola, 1997), we used a technique that increased the total sample volume, thus improving the sampling of particles larger than $64 \mathrm{~mm}$. As sediment was shoveled into four 5-gallon buckets, all the particles greater than $64 \mathrm{~mm}$ were removed and hand sieved using a hand-held size analyzer and the less-than-64-mm sediment deposited in the buckets. We assumed that the particle-size distribution of the less-than-64-mm sediment in the four buckets was equal and completed further grain-size analyses of the less-than-64$\mathrm{mm}$ fraction using sediment from a single bucket, which is an important consideration when sediment must be transported to a laboratory facility for sieving of the less-than-11-mm particles. The less-than-64-mm sediment from one bucket was sundried and field sieved at 0.5 phi intervals that ranged from 64 to $11 \mathrm{~mm}$. Particles smaller than $11 \mathrm{~mm}$ were transported to a USGS sediment lab located in Sacramento, California, where

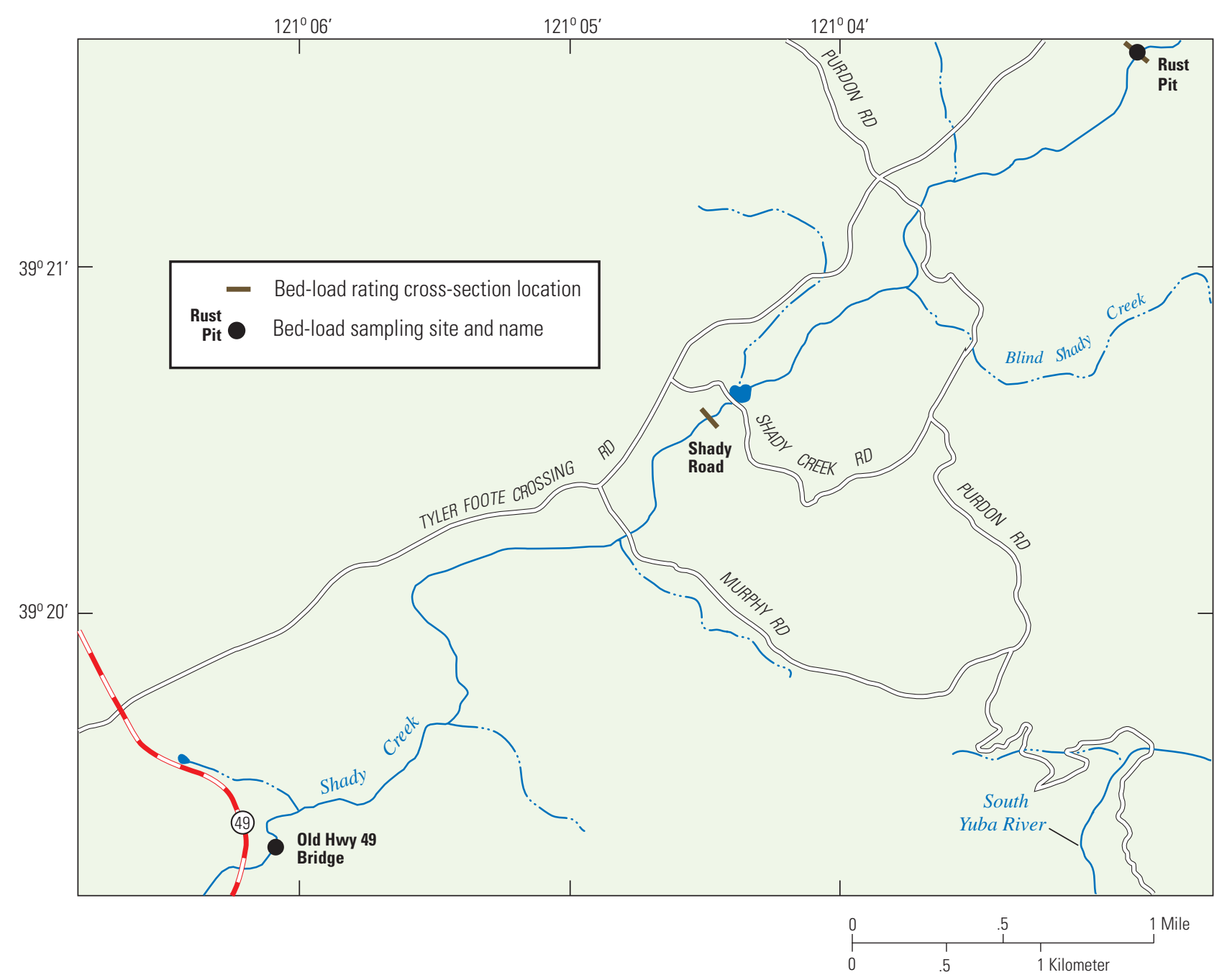

Figure 6. Location of bed-load sampling sites and cross-section bed-load transport locations along Shady Creek in the upper Yuba River watershed, California. 
they were oven-dried and laboratory sieved at 0.5 phi intervals ranging from 11 to $0.063 \mathrm{~mm}$. Church and others (1987) recommend much larger sample sizes than were collected in this study. The suggested sample size would have required earthmoving equipment. For this study, the added time and expense were not justifiable.

\section{Bed-Load Rating Curves}

To compute total sediment transport at the Middle Yuba River (11410000) and the South Yuba River (11417500) gages, bed-load transport had to be estimated. Regression relations between measured bed-load transport and streamflow could not be developed because logistics and expense precluded collection of bed-load measurements on the Middle Yuba and South Yuba Rivers. Therefore, bed-load transport rates were predicted using an empirical relation that relates sediment transport to the hydraulic conditions of the channel and to the sediment available for transport on the bed.

A single representative grain size was used in early studies (Meyer-Peter and Müller, 1948) to determine bed-load rating relations; consequently, these relations cannot account for different grain sizes moving at different rates. More recent bedload relations can be used to predict transport rates for many individual grain sizes (Parker and others, 1982; Parker, 1990) but are limited to grain sizes larger than $2.0 \mathrm{~mm}$. Using a series of flume experiments Wilcock and others (2001) concluded that small proportions of sand can cause nonlinear increases in bedload transport, thereby causing predictions of greater bed-load transport rates. These flume data were used to develop an empirical mixed-size bed-load transport relation (Hopkins model; Wilcock and Crowe, 2003).

Bed-load transport rates were calculated for a range of streamflow values using the Hopkins model, which was developed from 48 observations of flow, transport, and bed-surface grain size (Wilcock and others, 2001). The 48 experimental runs spanned a four-fold range in streamflow (volumetric water discharge per unit width $=0.32 \mathrm{ft}^{2} / \mathrm{s}$ to $1.39 \mathrm{ft}^{2} / \mathrm{s}$ ) and a 6 orderof-magnitude range in total sediment transport (0.0007 to 2,977 $\mathrm{g} / \mathrm{ft} / \mathrm{s})$. Sediment used in the flume experiments were sand and gravel mixtures with gravel sizes ranging from 2.0 to $64 \mathrm{~mm}$ and sand sizes ranging from 0.2 to $2.0 \mathrm{~mm}$. The proportion of sand in the sediment mixtures ranged from 6.2 to 34.3 percent, and the proportion of surface sand was measured following each experimental flume run and varied from 0.1 to 48 percent.

It is commonly advised that sediment transport models be applied only under conditions similar to those for which the model was developed. At the Middle Yuba River (11410000) gage, South Yuba River (11417500) gage, and Shady Creek sites, the streamflows of interest ranged from 18 to $4,800 \mathrm{ft}^{3} / \mathrm{s}$, which equates to unit streamflows of $2.2 \mathrm{ft}^{2} / \mathrm{s}$ to $28.0 \mathrm{ft}^{2} / \mathrm{s}$. Although application of the Hopkins model for the upper Yuba River sites requires significant extrapolation beyond the maximum measured unit streamflow $\left(1.39 \mathrm{ft}^{2} / \mathrm{s}\right)$ in the empirical data set of the model, the mean daily unit streamflow at the Middle Yuba River (11410000) and South Yuba River (11417500) gages exceeded this value $\left(1.39 \mathrm{ft}^{2} / \mathrm{s}\right)$ only about 5 percent of the time. Granted the percentage of the annual bed load transported at these higher flows was likely much greater than 5 percent; however, bed load was not measured and therefore the percentage of bed-load transport represented by the empirical dataset could not be determined. However, the percentage of sand in surface samples of bed material collected at the Middle Yuba River (11410000) gage, South Yuba River (11417500) gage, and at the Shady Creek sites ranged from 1.7 to 3.4 percent, which is within the range of the surface sand proportions in the empirical data set of the model.

The Hopkins model requires estimates of the surface grain-size distribution, water-surface slope, and shear velocities associated with the streamflow of interest. Laboratory analyses of bed material from the Middle Yuba River (11410000) and South Yuba River (11417500) gage sites and pebble counts (Wolman, 1954) at the Shady Creek sites were used to define surface grain-size distributions (fig. 7). Water-surface slopes were determined from longitudinal surveys of water-surface elevations measured using a surveyor's transit level and a stadia rod along $500 \mathrm{ft}$ of channel distance. Water-surface slope and surface grain-size distributions were assumed to be stationary for the range of streamflow analyzed.

Methods used to estimate bed-shear velocities warrant a detailed explanation. Bed-shear stress can be partitioned into skin friction, the portion of stress that is exerted on individual grains and thus responsible for transport, and form drag attributable to large roughness elements, such as bedforms, boulders, bedrock outcrops, or large trees within the active channel. When applying a transport predictor such as the Hopkins model, only the skin-friction portion of bed-shear stress should be used to compute bed-shear velocities. Because bed-shear stresses in the upper Yuba River include a significant component of form drag, this term was removed before computing the shear velocities used in the Hopkins model. Skin friction was estimated using a form of the Einstein-Keulegan relation defined for a mixture of bed particles (Andrews, 1983)

$$
\begin{gathered}
\mathrm{U}^{\prime} \mathrm{U}^{*}=2.5^{*} \ln \left(3.7 \mathrm{~h}^{1} / \mathrm{D}_{84}\right) \\
\mathrm{U}^{*}=\left(\mathrm{g} \mathrm{h}^{1} \mathrm{~S}\right)^{1 / 2}
\end{gathered}
$$

where $\mathrm{U}$ is mean velocity, $\mathrm{U}^{*}$ is bed-shear velocity, $\mathrm{h}^{1}$ is the portion of the flow depth attributed solely to skin friction, $\mathrm{D}_{84}$ is the grain size representing 84 percent of the bed-surface material, $\mathrm{g}$ is gravitational acceleration, and $\mathrm{S}$ is water-surface slope. Estimates of skin friction (bed-shear velocity minus the formdrag component) for a range of streamflows (0 to $\left.5,000 \mathrm{ft}^{3} / \mathrm{s}\right)$ were calculated by solving both sides of equation 9 for $\mathrm{h}^{1}$ iteratively using EXCEL Solver. In the absence of form drag, $h^{1}=h$; thus, $\mathrm{h}^{1}$ represents a hypothetical flow depth that can be used to estimate bed-shear velocities attributable solely to skin friction. Calculation of $\mathrm{h}^{1}$ required estimates of $\mathrm{U}, \mathrm{S}$, and $\mathrm{D}_{84}$ for a range of streamflows ( 0 to $\left.5,000 \mathrm{ft}^{3} / \mathrm{s}\right)$. Mean velocities (U) for the 


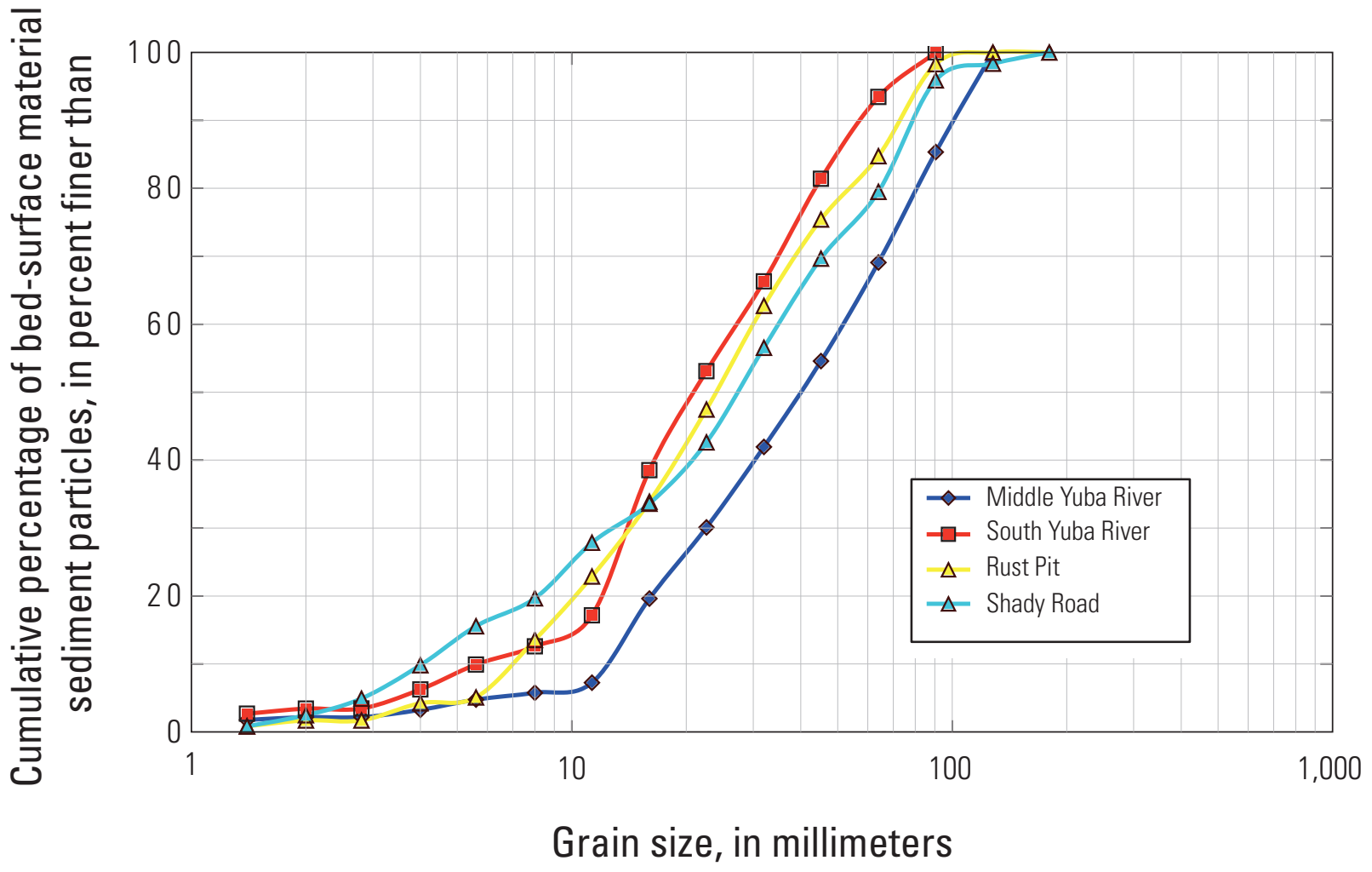

Figure 7. Cumulative percentage of the grain-size distribution of bed-surface material for two bed-load sampling sites located in Shady Creek and gaging stations on the Middle Yuba River (11410000) and South Yuba River (11417500) in the upper Yuba River watershed, California.

range of streamflows were estimated using mean velocity and streamflow relations (fig. 8), whereas slope $(\mathrm{S})$ and $\mathrm{D}_{84}$ were estimated using field data. At the Middle Yuba River (11410000) gage, channel geometry changes between the low (wading site) and high (bridge site) streamflow measurement sites necessitated development of two separate velocity-streamflow relations (fig. 8). The high-flow relation was used to develop the Middle Yuba River (11410000) gage bed-load rating curve.

\section{Shady Creek Bed-Load Measurements}

Bed-load samples collected on Shady Creek (a tributary to the South Yuba River) were used to assess the accuracy of the bed-load rating curves developed using the Hopkins model. Concurrent streamflow and bed-load measurements were collected at two locations along Shady Creek (fig. 6) using standard sampling techniques (Edwards and Glysson, 1999).
Single equal-width increment (EWI) samples were collected using a BL-84 cable-operated bed-load sampler at the Old Hwy 49 Bridge site and a BLH-84 hand-held sampler at the Rust Pit wading site (fig. 6). Both samplers have a 3-squareinch entrance nozzle and an area expansion ratio (ratio of nozzle exit area to entrance area) of 1.40. Samples were collected at the midpoints of evenly spaced verticals and sampling times at each vertical were equal. This allowed composite samples to be prepared for laboratory analyses. The bed-load samples were oven dried, weighed, and sieved at 0.5 phi intervals that ranged from 0.063 to $180 \mathrm{~mm}$. Bed-load discharge (tons/day) was calculated as

$$
\mathrm{q}_{\mathrm{bi}}=\mathrm{k}(\mathrm{M} / \mathrm{T})
$$

where $\mathrm{q}_{\mathrm{bi}}$ is the bed-load transport rate (tons/day); $\mathrm{k}$ is a conversion factor, based on the width of the sampler nozzle $(0.381$ for 3-in. nozzles used here) used to convert grams/second into tons/day; $\mathrm{M}$ is total mass of the bed-load sample (grams); and $\mathrm{T}$ is the total time the sampler was on the channel bed (seconds). 


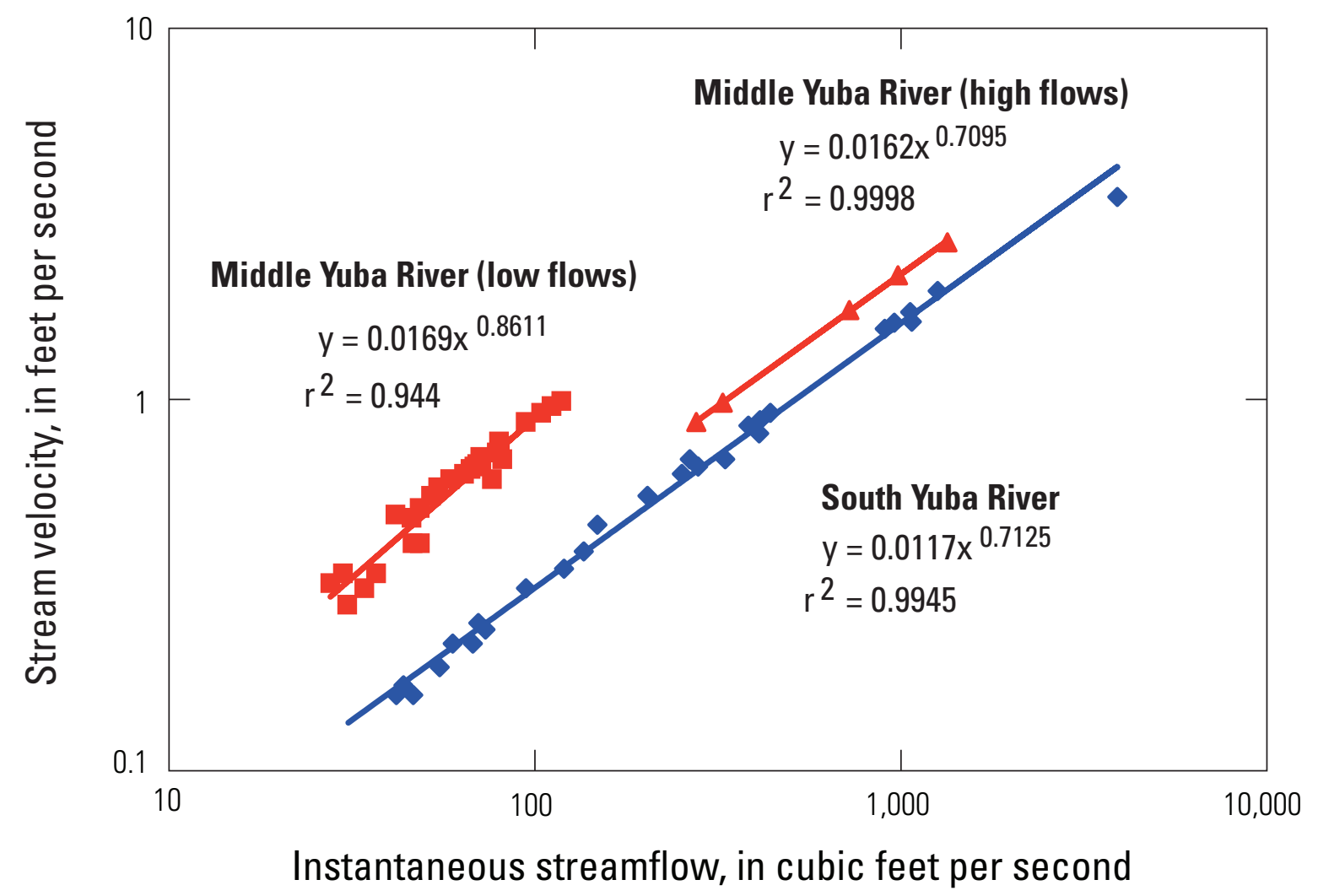

EXPLANATION

$\rightarrow \quad$ Middle Yuba River low flows

Middle Yuba River high flows

$\leadsto \quad$ South Yuba River

Figure 8. Mean velocity and streamflow relations for gaging stations on the Middle Yuba River (11410000) and South Yuba River (11417500) in the upper Yuba River watershed, California. Note that streamflow measurements were collected at two sites near the Middle Yuba River gaging station: a wading site during low flows and at a bridge site during higher flows. 


\section{Results}

\section{Suspended Sediment}

\section{Storm Sampling}

Storm sampling provided information regarding the timing of suspended-sediment concentration and streamflow peaks as well as information about varying grain-size distributions during storm events. Storm hydrographs, suspended-sediment concentrations, and percent sand are shown in figure 9A-D. Sediment sampling missed the November 2002 streamflow peak (fig. 9A); however, several sediment peaks that arrived prior to the storm peak were sampled and are characteristic of abundant sediment supply during first flush conditions. During the December 2002 storm event, the peak in suspended-sediment concentration coincided with the peak in streamflow (fig. 9B). We inferred that this was indicative of an abundant sediment supply during transport-limited winter storm conditions. During the February 2003 storm, the peaks in suspended-sediment concentration and streamflow coincided at the South Yuba River gage, again inferred to represent winter storm conditions, but the peak in suspended-sediment concentration was delayed at the Middle Yuba River (11410000) gage (fig. 9C). During the March 2003 storm, the peak in suspended-sediment concentrations arrived approximately 3 hours earlier than the peak in streamflow at the Middle Yuba River (11410000) gage and 6 hours earlier than the streamflow peak at the South Yuba River (11417500) gage (fig. 9D). The early arrival of sediment peaks indicated a limited supply of sediment. For the most part, concentrations of sand change systematically over the storm hydrographs with the lowest percentage of sand on the rising limb, greater percentages on the falling limb, and the highest percentages at the peak, indicating some hysteresis in sand concentrations.
Another observation made during storm sampling was of anomalously high suspended-sediment concentrations at the Middle Yuba River (11410000) gage on December 16, 2002 (see inset figure 9B). Significant volumes of sediment are stored behind Log Cabin Dam and Our House Dam (fig. 1), which require periodic dredging (Yuba County Water Agency, 1989). During large runoff events, these facilities discharge water over their spillways, and previously impounded sediment may be scoured and conveyed downstream resulting in elevated suspended-sediment concentrations at the Middle Yuba River (11410000) gage. Log Cabin Dam spilled again during the March 2003 storm sampling, but the impact of the spill was less dramatic in the March 2003 data set. During the March 2003 event, the peak in suspended-sediment concentration coincided with the peak of the spill, but the peak in streamflow at the Middle Yuba River (11410000) gage did not occur until several hours later. The magnitude of the December 2002 and March 2003 streamflows were similar, which may indicate that the first spill event of the water year flushed most of the finer impounded sediment available for transport over the spillway.

\section{Grain-Size Analysis of Suspended Sediment}

Suspended-sediment concentrations and grain sizes of sand-size material measured at the U.S. Geological Survey laboratory in Marina, California, are presented in table 2. Samples processed at the Marina laboratory did not meet the minimum sample mass requirement for pipet analyses of the less-than$0.063-\mathrm{mm}$ sized sediment. However, the less-than-0.063-mm grain-size fraction of replicate samples sent to the USGS sediment laboratory in Menlo Park, California, was analyzed using a laser-diffraction particle-size analyzer. Suspended-sediment concentration, median and mean grain sizes (in $\mu \mathrm{m}$ ), and percentages of clay (less than $0.004 \mathrm{~mm}$ ), silt (0.004 to $0.063 \mathrm{~mm}$ ), and sand $(0.063 \mathrm{~mm}$ to $2.0 \mathrm{~mm})$ measured at the Menlo Park laboratory are presented in table 3 ; full grain-size distributions are presented in Appendix 2. 


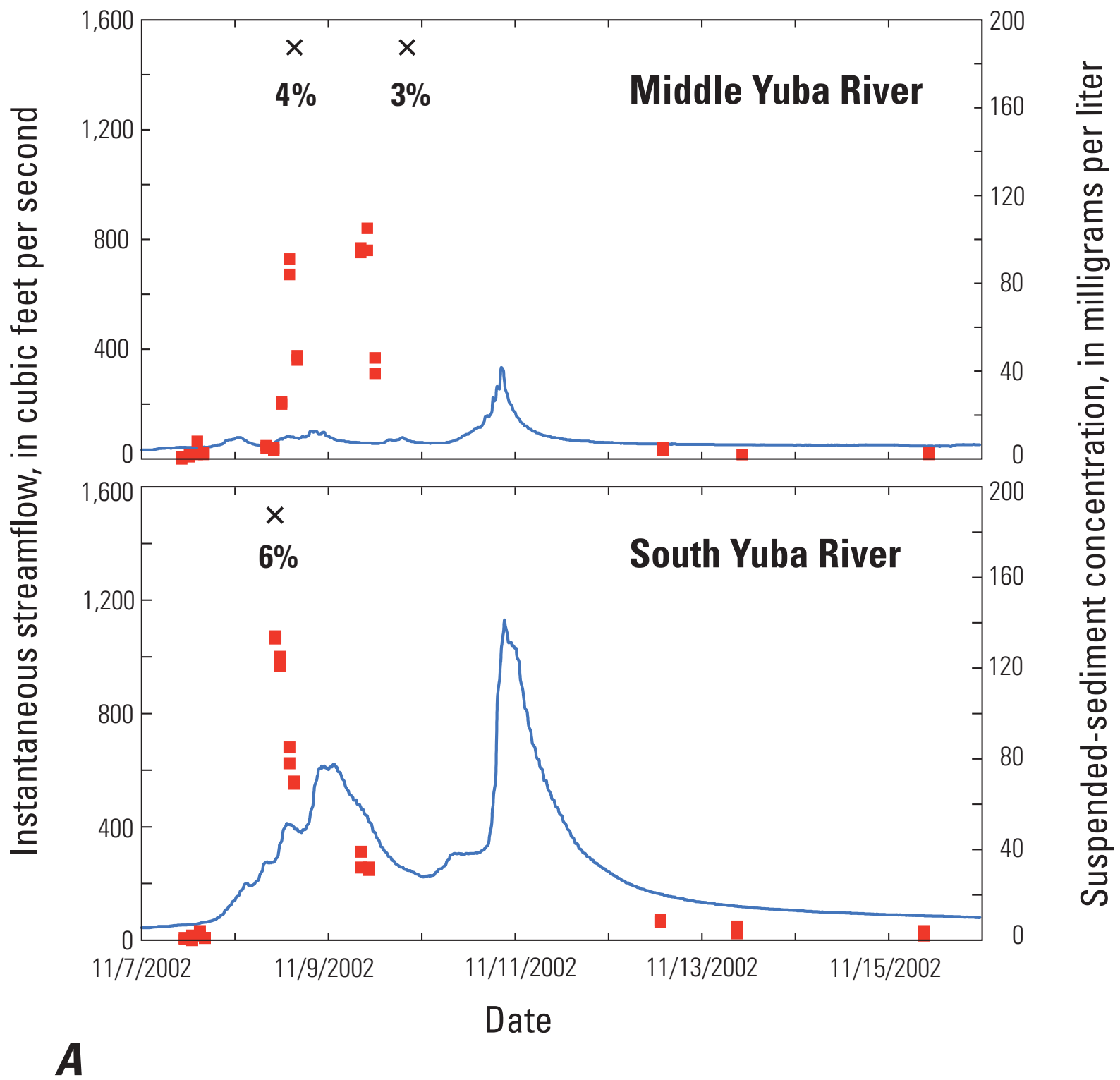

EXPLANATION

- Streamflow $\times \begin{aligned} & \text { Percent sand in suspended } \\ & \text { sediment }\end{aligned} \quad \begin{aligned} & \text { Suspended-sediment } \\ & \text { concentration }\end{aligned}$

Figure 9. Instantaneous streamflow, suspended-sediment concentrations, and percent sand of suspended sediment during storm events at the Middle Yuba River (11410000) and South Yuba River (11417500) gaging stations in the upper Yuba River watershed, California. A, November 2002; B, December 2002; C, February 2003; and D, March 2003. X's denote the date and time of samples analyzed for percent sand, and there are no grain-size data from the February 2003 event at Middle Yuba River gage. 


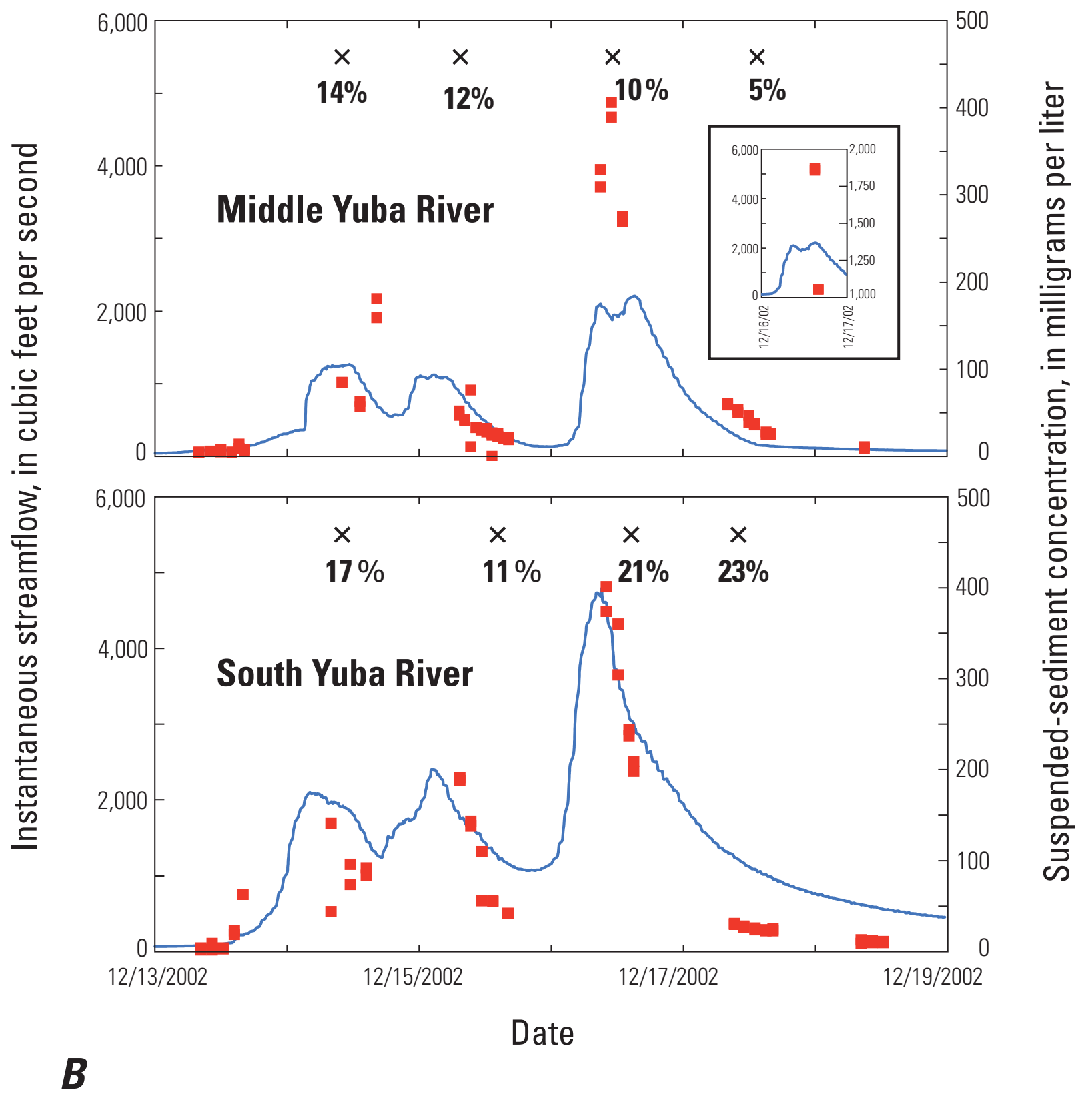

\section{EXPLANATION}

- Streamflow $\times$ Percent sand in suspended sediment

- Suspended-sediment concentration

Figure 9. Continued. 


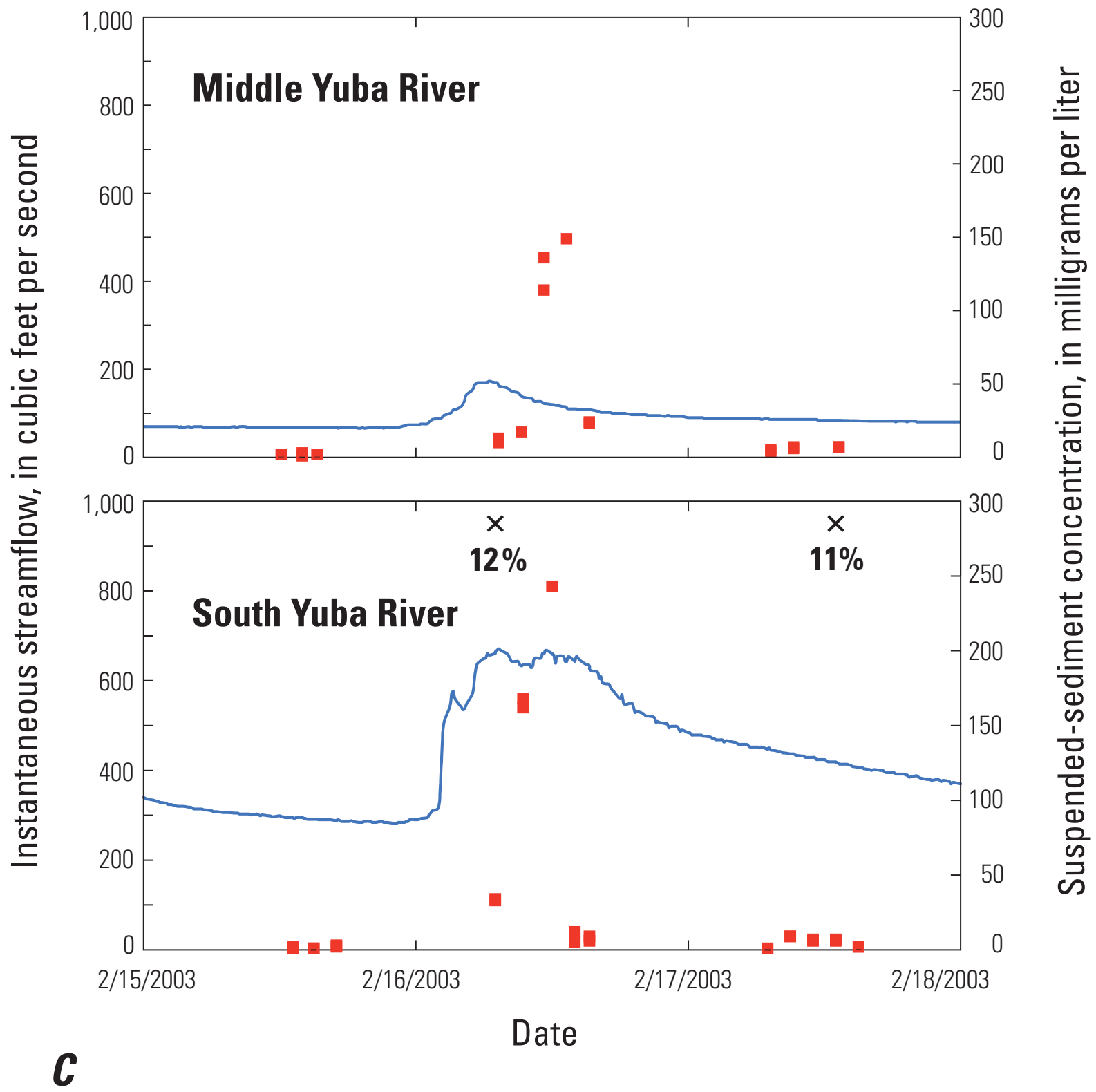

\section{EXPLANATION}

- Streamflow $\quad \times$ Percent sand $\square \begin{aligned} & \text { Suspended-sediment } \\ & \text { concentration }\end{aligned}$

Figure 9. Continued. 


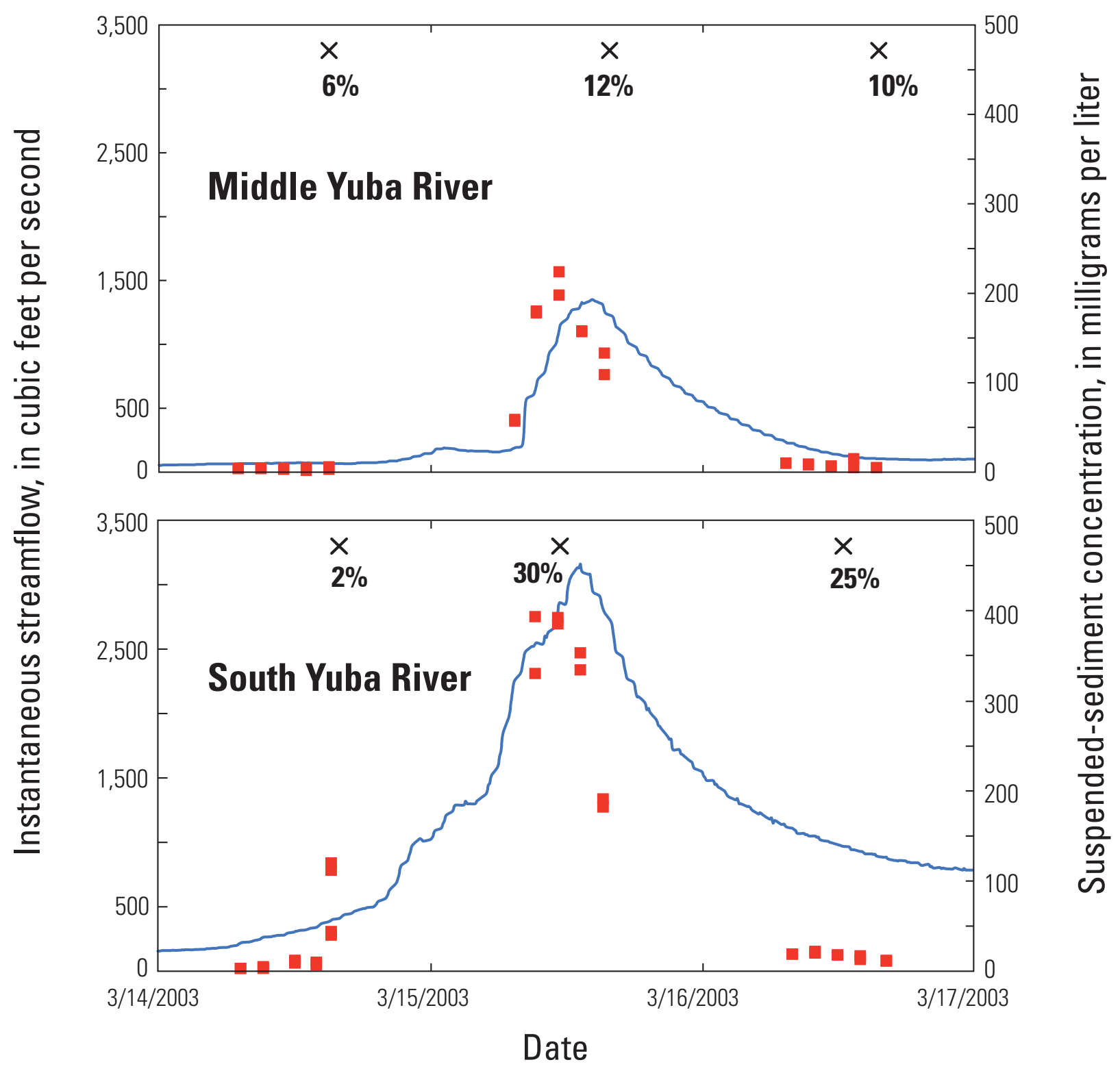

D

\section{EXPLANATION}

- Streamflow $\quad \times$ Percent sand $\quad \begin{aligned} & \text { Suspended-sediment } \\ & \text { concentration }\end{aligned}$

Figure 9. Continued. 
Table 2. Summary of streamflow, suspended-sediment concentrations, and grain sizes of sand-sized suspended sediment at gaging stations in the upper Yuba River watershed, California.

[See figure 1 for station locations. Sand-size material measured by the U.S. Geological Survey in Marina, California. $\mathrm{ft}^{3} / \mathrm{s}$, cubic foot per second; mg/L, milligram per liter; mm, millimeter]

\begin{tabular}{|c|c|c|c|c|c|c|c|c|c|c|c|}
\hline $\begin{array}{c}\text { Map } \\
\text { identifier }\end{array}$ & $\begin{array}{c}\text { Station } \\
\text { identifier }\end{array}$ & Date & Time & $\begin{array}{c}\text { Streamflow } \\
\left(\mathrm{ft}^{3} / \mathrm{s}\right)\end{array}$ & $\begin{array}{l}\text { Suspended- } \\
\text { sediment } \\
\text { concentration } \\
(\mathrm{mg} / \mathrm{L})\end{array}$ & $\begin{array}{l}\text { Grain size } \\
\text { percent } \\
\text { finer than } \\
2.0 \mathrm{~mm} \\
\end{array}$ & $\begin{array}{c}\text { Grain size } \\
\text { percent } \\
\text { finer than } \\
1.0 \mathrm{~mm} \\
\end{array}$ & $\begin{array}{c}\text { Grain size } \\
\text { percent } \\
\text { finer than } \\
0.5 \mathrm{~mm} \\
\end{array}$ & $\begin{array}{c}\text { Grain size } \\
\text { percent } \\
\text { finer than } \\
0.25 \mathrm{~mm} \\
\end{array}$ & $\begin{array}{c}\text { Grain size } \\
\text { percent } \\
\text { finer than } \\
0.125 \mathrm{~mm} \\
\end{array}$ & $\begin{array}{c}\text { Grain size } \\
\text { percent } \\
\text { finer than } \\
0.063 \mathrm{~mm}\end{array}$ \\
\hline \multirow[t]{13}{*}{ MYG } & 11410000 & $11 / 08 / 02$ & $15: 15$ & 88 & 55 & & 100 & 99 & 98 & 98 & 96 \\
\hline & & 11/09/02 & 08:15 & 66 & 96 & & 100 & 98 & 98 & 97 & 97 \\
\hline & & $12 / 14 / 02$ & $10: 00$ & 1,250 & 79 & & 100 & 99 & 97 & 92 & 86 \\
\hline & & $12 / 15 / 02$ & $07: 30$ & 883 & 48 & & 100 & 98 & 96 & 92 & 88 \\
\hline & & $12 / 16 / 02$ & $11: 50$ & 1,950 & 374 & & 100 & 98 & 95 & 93 & 90 \\
\hline & & $12 / 16 / 02$ & $11: 50$ & 1,950 & 375 & 100 & 97 & 96 & 95 & 93 & 90 \\
\hline & & $12 / 16 / 02$ & $11: 50$ & 1,950 & 360 & & 100 & 99 & 97 & 95 & 94 \\
\hline & & $12 / 17 / 02$ & $13: 25$ & 170 & 35 & & & 100 & 99 & 98 & 95 \\
\hline & & $12 / 18 / 02$ & $10: 00$ & 95 & 10 & & & 100 & 97 & 93 & 92 \\
\hline & & $12 / 30 / 02$ & $12: 00$ & 150 & 5 & & & & & & ${ }^{194}$ \\
\hline & & 03/14/03 & $15: 00$ & 63 & 7 & & & & & & ${ }^{1} 94$ \\
\hline & & 03/15/03 & $15: 45$ & 1,230 & 218 & & 100 & 99 & 98 & 96 & 88 \\
\hline & & 03/16/03 & $15: 30$ & 100 & 6 & & & & & & 190 \\
\hline \multirow[t]{18}{*}{ SYG } & 11417500 & 11/08/02 & $10: 15$ & 279 & 116 & & 100 & 100 & 99 & 97 & 94 \\
\hline & & $12 / 13 / 02$ & $14: 22$ & 123 & 12 & & 100 & 100 & 76 & 72 & 65 \\
\hline & & $12 / 14 / 02$ & 08:00 & 1,970 & 145 & & 100 & 100 & 90 & 87 & 83 \\
\hline & & $12 / 15 / 02$ & $14: 15$ & 1,270 & 50 & & 100 & 100 & 96 & 93 & 89 \\
\hline & & $12 / 16 / 02$ & $14: 35$ & 3,060 & 223 & & 100 & 100 & 89 & 84 & 79 \\
\hline & & $12 / 17 / 02$ & 09:52 & 1,240 & 30 & & 100 & 100 & 93 & 87 & 79 \\
\hline & & $12 / 17 / 02$ & $10: 11$ & 1,220 & 29 & & & & 92 & 86 & 78 \\
\hline & & $12 / 17 / 02$ & $10: 11$ & 1,220 & 31 & & 100 & 100 & 89 & 82 & 73 \\
\hline & & $12 / 18 / 02$ & 09:40 & 605 & 13 & & & & 95 & 88 & 79 \\
\hline & & $12 / 30 / 02$ & $16: 00$ & 750 & 14 & & & & 93 & 87 & 79 \\
\hline & & $12 / 31 / 02$ & $11: 31$ & 1,190 & 199 & & 100 & 100 & 99 & 99 & 98 \\
\hline & & 02/16/03 & 07:00 & 661 & 39 & & 100 & 100 & 95 & 91 & 87 \\
\hline & & 02/16/03 & 07:00 & 661 & 36 & & 100 & 100 & 95 & 93 & 88 \\
\hline & & 02/17/03 & $13: 00$ & 419 & 7 & & & & & & ${ }^{19}$ \\
\hline & & 02/17/03 & $13: 00$ & 419 & 8 & & & & & & ${ }^{1} 86$ \\
\hline & & 03/14/03 & $16: 00$ & 409 & 89 & & & & 99 & 99 & 98 \\
\hline & & 03/15/03 & $11: 30$ & 2,790 & 404 & 100 & 97 & 97 & 80 & 76 & 70 \\
\hline & & 03/16/03 & $12: 30$ & 974 & 18 & & & & 92 & 85 & 75 \\
\hline \multirow[t]{2}{*}{ YRE } & 11418000 & 03/15/03 & $14: 10$ & 5,400 & 10 & & & & & & 189 \\
\hline & & 03/16/03 & $10: 45$ & 2,980 & 3 & & & & & & ${ }^{195}$ \\
\hline
\end{tabular}

\footnotetext{
${ }^{1}$ Insufficient samples; therefore, percent finer than $0.063 \mathrm{~mm}$ only.
} 
Table 3. Summary of streamflow, suspended-sediment concentrations, and grain sizes of suspended sediment collected at gaging stations in the upper Yuba River watershed, California.

[See figure 1 for station locations. Grain-size material measured at the U.S. Geological Survey in Menlo Park, California. $\mathrm{ft}^{3} / \mathrm{s}$, cubic foot per second; $\mathrm{mg} / \mathrm{L}$, milligram per liter; $\mathrm{mm}$, millimeter; $\mu \mathrm{m}$, micrometer]

\begin{tabular}{|c|c|c|c|c|c|c|c|c|c|c|}
\hline $\begin{array}{c}\text { Map } \\
\text { identifier }\end{array}$ & $\begin{array}{c}\text { Station } \\
\text { identifier }\end{array}$ & Date & Time & $\begin{array}{l}\text { Streamflow } \\
\left(\mathrm{ft}^{3} / \mathrm{s}\right)\end{array}$ & $\begin{array}{c}\text { Suspended } \\
\text { sediment } \\
\text { concentration } \\
(\mathrm{mg} / \mathrm{L})\end{array}$ & $\begin{array}{c}\text { Sand } \\
\text { (greater } \\
\text { than } 0.063 \\
\mathrm{~mm})(\%) \\
\end{array}$ & $\begin{array}{c}\text { Silt }(0.004 \\
\text { to } 0.063 \\
\mathrm{~mm})(\%)\end{array}$ & $\begin{array}{c}\text { Clay (less } \\
\text { than } 0.004 \\
\text { to } 0.063 \\
\mathrm{~mm})(\%)\end{array}$ & $\begin{array}{c}\text { Grain size, } \\
\text { median } \\
(\mu \mathrm{m})\end{array}$ & $\begin{array}{l}\text { Grain size, } \\
\text { mean }(\mu \mathrm{m})\end{array}$ \\
\hline \multirow[t]{16}{*}{ MYG } & \multirow[t]{16}{*}{11410000} & $11 / 08 / 02$ & $15: 20$ & 88 & 48 & 2 & 30 & 68 & 3 & 3 \\
\hline & & $11 / 09 / 02$ & 08:17 & 66 & 82 & 0 & 31 & 69 & 3 & 2 \\
\hline & & $12 / 14 / 02$ & $10: 00$ & 1,250 & 69 & 7 & 70 & 23 & 11 & 11 \\
\hline & & $12 / 15 / 02$ & $07: 30$ & 889 & 37 & 0 & 62 & 38 & 6 & 5 \\
\hline & & $12 / 17 / 02$ & $13: 25$ & 170 & 39 & 2 & 65 & 33 & 6 & 6 \\
\hline & & $12 / 18 / 02$ & $10: 00$ & 100 & 9 & 0 & 58 & 42 & 5 & 4 \\
\hline & & $12 / 30 / 02$ & $12: 00$ & 153 & 4 & 0 & 61 & 39 & 5 & 5 \\
\hline & & 02/06/03 & 08:00 & 158 & 13 & 1 & 54 & 45 & 5 & 4 \\
\hline & & 02/16/03 & 08:00 & 158 & 12 & 0 & 58 & 42 & 5 & 5 \\
\hline & & 02/17/03 & $14: 00$ & 83 & 5 & 0 & 48 & 52 & 4 & 4 \\
\hline & & 02/17/03 & $14: 00$ & 83 & 10 & 0 & 65 & 35 & 6 & 6 \\
\hline & & $02 / 17 / 03$ & $14: 00$ & 83 & 13 & 0 & 41 & 59 & 3 & 3 \\
\hline & & 03/14/03 & $15: 00$ & 70 & 12 & 0 & 55 & 45 & 5 & 5 \\
\hline & & 03/15/03 & $15: 45$ & 1,240 & 223 & 8 & 66 & 26 & 10 & 9 \\
\hline & & 03/15/03 & $15: 45$ & 1,240 & 219 & 7 & 65 & 28 & 9 & 9 \\
\hline & & 03/16/03 & $15: 30$ & 105 & 8 & 0 & 54 & 46 & 5 & 4 \\
\hline \multirow[t]{14}{*}{ SYG } & \multirow[t]{14}{*}{11417500} & $\begin{array}{l}11 / 08 / 02 \\
12 / 13 / 02\end{array}$ & $\begin{array}{l}10: 22 \\
14: 22\end{array}$ & $\begin{array}{l}279 \\
123\end{array}$ & $\begin{array}{c}105 \\
18\end{array}$ & $\begin{array}{l}0 \\
0\end{array}$ & $\begin{array}{l}59 \\
48\end{array}$ & $\begin{array}{l}41 \\
52\end{array}$ & $\begin{array}{l}5 \\
4\end{array}$ & $\begin{array}{l}5 \\
4\end{array}$ \\
\hline & & $12 / 14 / 02$ & 08:00 & 1,970 & 128 & 9 & 56 & 35 & 6 & 8 \\
\hline & & $12 / 15 / 02$ & $14: 15$ & 1,270 & 49 & 6 & 62 & 32 & 7 & 7 \\
\hline & & $12 / 16 / 02$ & $14: 35$ & 3,060 & 87 & 18 & 60 & 22 & 10 & 15 \\
\hline & & $12 / 18 / 02$ & 09:40 & 605 & 9 & 17 & 56 & 27 & 9 & 11 \\
\hline & & $12 / 30 / 02$ & $16: 00$ & 750 & 11 & 10 & 57 & 33 & 7 & 8 \\
\hline & & $12 / 31 / 02$ & $11: 30$ & 1,190 & 208 & 1 & 58 & 41 & 5 & 5 \\
\hline & & 02/16/03 & 07:00 & 661 & 36 & 7 & 59 & 34 & 7 & 7 \\
\hline & & 02/17/03 & 13:00 & 419 & 5 & 9 & 58 & 33 & 7 & 7 \\
\hline & & 03/14/03 & $16: 00$ & 409 & 90 & 1 & 54 & 45 & 4 & 4 \\
\hline & & 03/14/03 & $16: 00$ & 409 & 83 & 0 & 52 & 48 & 4 & 4 \\
\hline & & 03/15/03 & $11: 30$ & 2,790 & 411 & 22 & 50 & 28 & 9 & 15 \\
\hline & & 03/15/03 & $11: 30$ & 2,790 & 415 & 24 & 49 & 27 & 9 & 15 \\
\hline & & 03/16/03 & $12: 30$ & 974 & 11 & 2 & 63 & 35 & 7 & 6 \\
\hline \multirow[t]{2}{*}{ YRE } & \multirow[t]{2}{*}{11418000} & $03 / 15 / 03$ & $14: 10$ & 5,400 & 10 & 0 & 54 & 46 & 4 & 4 \\
\hline & & 03/16/03 & 10:45 & 2,980 & 10 & 0 & 56 & 44 & 5 & 5 \\
\hline
\end{tabular}


Normalized by the mean of the two measurements, the concentrations measured in the Marina laboratory were on average 4.9 percent higher than those measured in the Menlo Park laboratory. Generally higher concentrations measured at the Marina laboratory may reflect the different sample-processing techniques used in the two laboratories (removal of organic material from the full sample and ultrasonicating at Menlo Park). The Marina laboratory measurements of sand content averaged 7.0 percent higher than the measurements at the Menlo Park laboratory. This difference may reflect the removal of organic material, perhaps because the $\mathrm{H}_{2} \mathrm{O}_{2}$ reaction not only dissolves free-floating organic material but also the thin organic films on the surfaces of sediment grains. In addition, ultrasound dispersal techniques used at the Menlo Park laboratory may break up particle aggregates thereby reducing grain size relative to the undispersed samples. Concentration and percent sand were measured in the Menlo Park laboratory both before and after removal of organics for a subset of 12 samples from February and March 2003. On average, suspended-sediment concentrations were 28.0 percent higher prior to removal of organic material (reflecting 3-26 mg/L of material removed during the reaction with $\mathrm{H}_{2} \mathrm{O}_{2}$ ) and sand contents were 1.4 percent greater.

Suspended sediment in the upper Yuba River watershed was dominantly silt and clay (typically greater than 85 percent) during water year 2003, and sand concentrations were higher at the South Yuba River (11417500) gage than at the Middle Yuba River (11410000) gage for similar streamflow rates (fig. 10). Small-volume (5 to 10 pints) samples collected for grain-size analyses resulted in high variability among processed replicate samples. These differences underscore the importance of using large-volume samples to obtain more precise grain-size analyses, especially during low-concentration conditions.

\section{Suspended-Sediment Rating Curves}

Group-average suspended-sediment rating curves for the Middle Yuba River (11410000) and South Yuba River (11417500) gages describe average, summer/fall, first flush, winter, and spring snowmelt conditions (fig. 11). The form and goodness-of-fit of regressions are shown in table 4. Suspendedsediment concentrations generally increase with increasing streamflow indicating an associated increase in stream power (the ability of the river to transport sediment); however, the slopes of the seasonal rating curves differ significantly. Variations in the slopes of the rating curves indicate changes in sediment supply throughout the water year. Under average and below-average precipitation conditions, such as occurred during the study period, sediment supply is greatest during the first flush of the water year; therefore, the first flush curves for the Middle Yuba and South Yuba Rivers have the greatest slopes. Sediment supplies decreased following the first flush; thus, the slopes of the winter rating curves are lower than those of the first flush curves. The spring and summer/fall rating curves had the lowest slopes, indicating lower sediment supplies during spring snowmelt conditions and throughout the dry summer and fall months. 

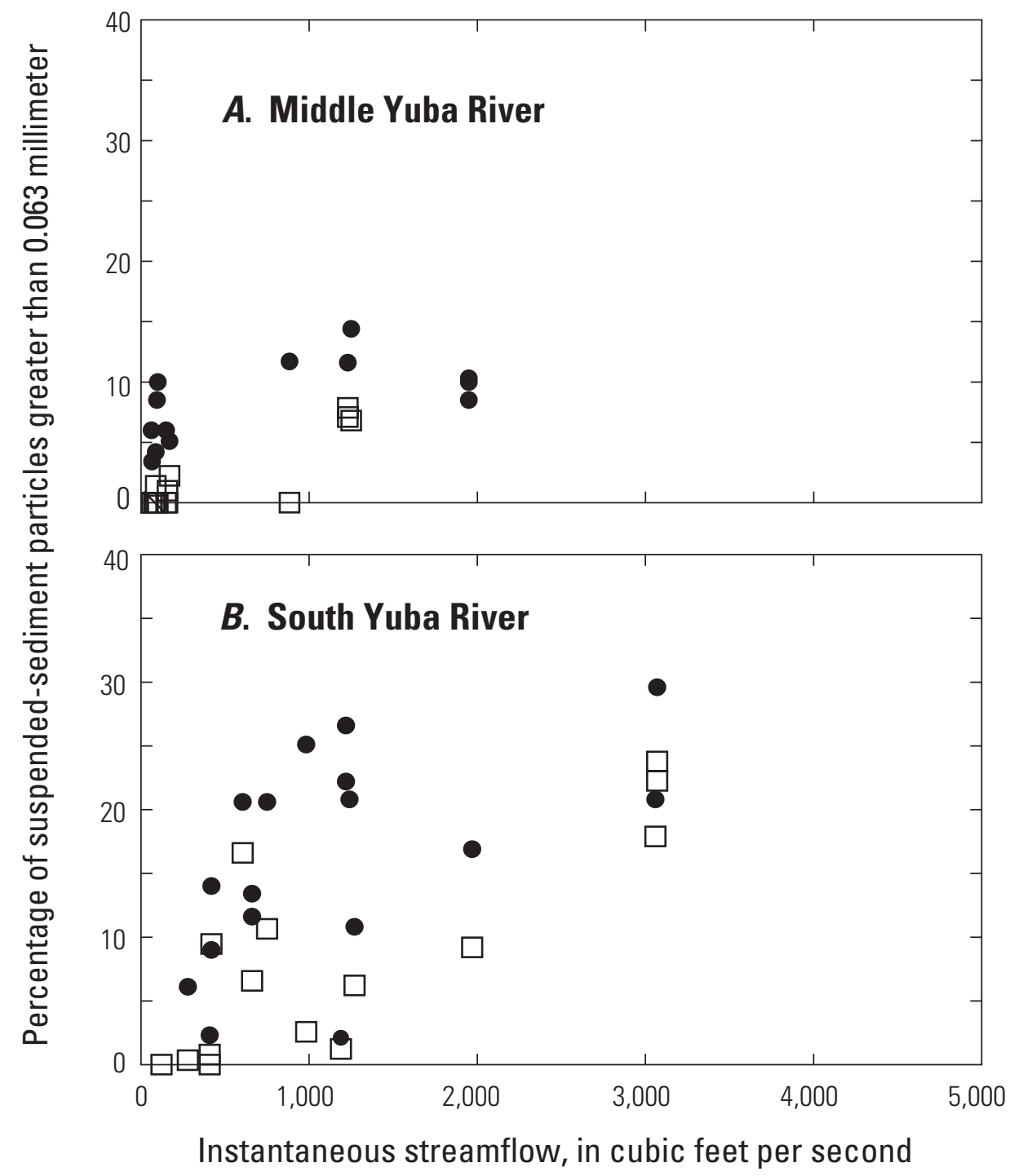

EXPLANATION

Samples analyzed at USGS laboratory located in

- Marina, California

$\square$ Menlo Park, California

Figure 10. Relation between percent sand (the proportion of suspended-sediment larger than 0.063 millimeter) and instantaneous streamflow for two gaging stations in the upper Yuba River watershed, California. A, Middle Yuba River (11410000). B, South Yuba River (11417500). 

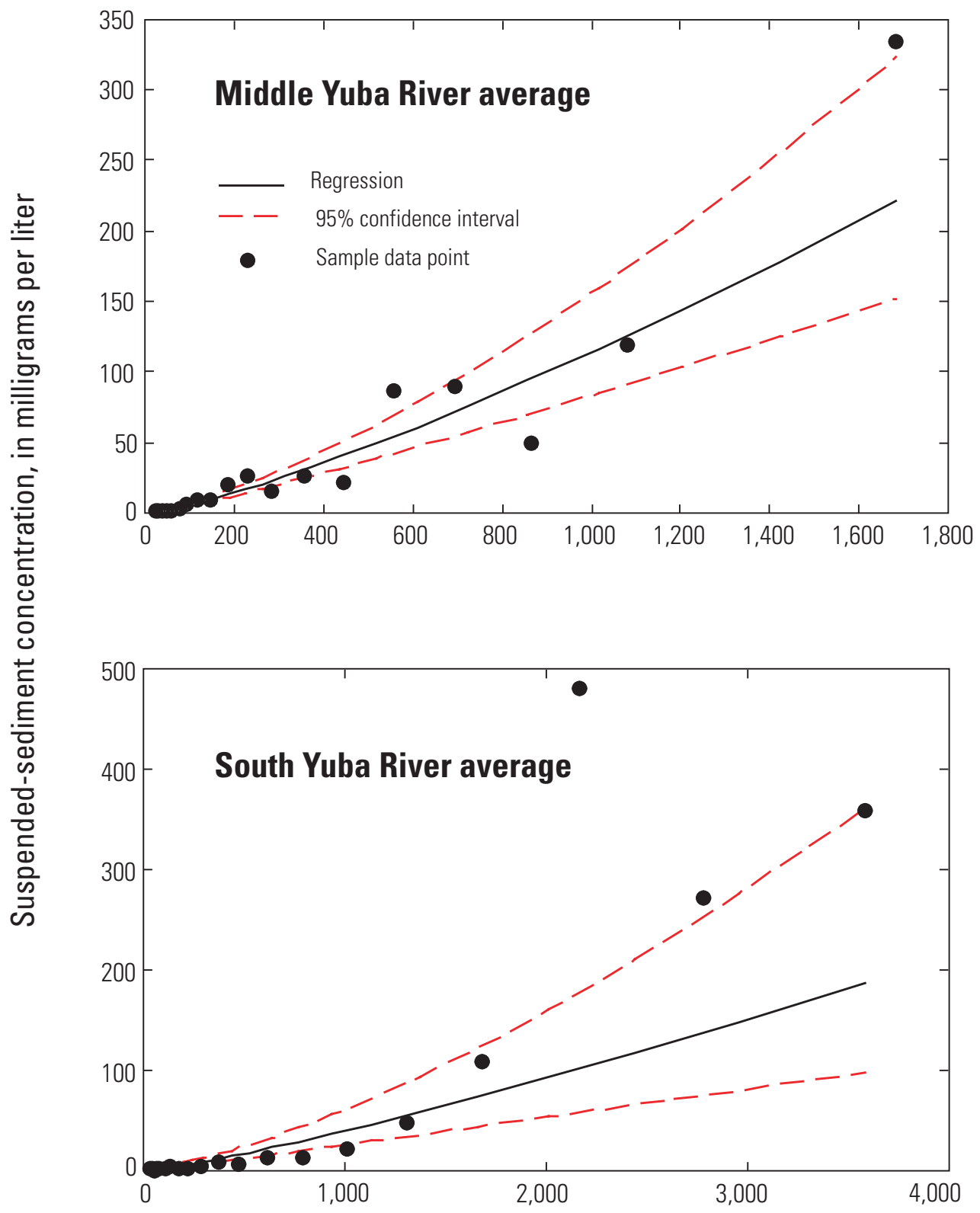

\section{$\boldsymbol{A}$}

Instantaneous streamflow, in cubic feet per second

Figure 11. Non-linear regression relations between suspended-sediment concentration and instantaneous streamflow for the Middle Yuba River (11410000) and South Yuba River (11417500) gaging stations in the upper Yuba River watershed, California. A, Average; B, Summer/Fall; C, Fall first flush; D, Winter; and E, Spring. See table 4 for regression equation form and summary statistics. 


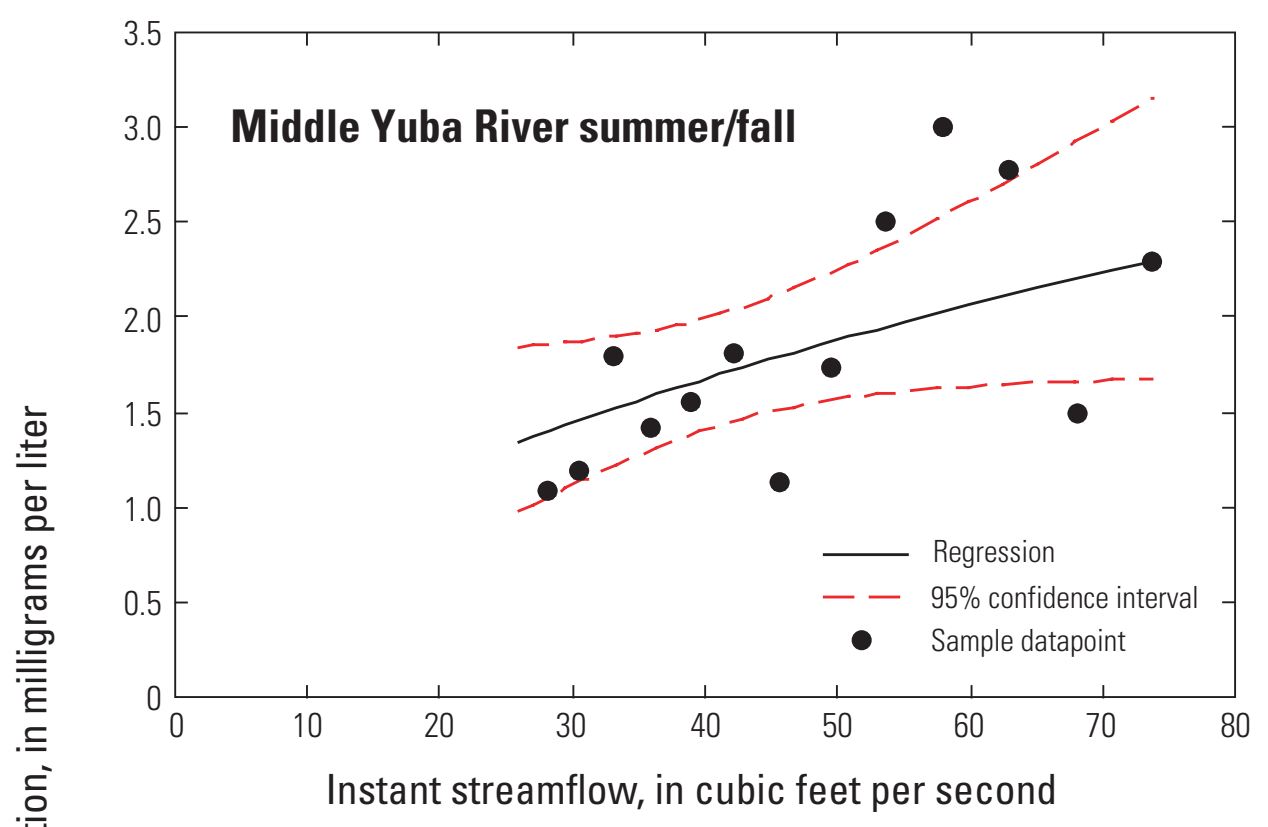




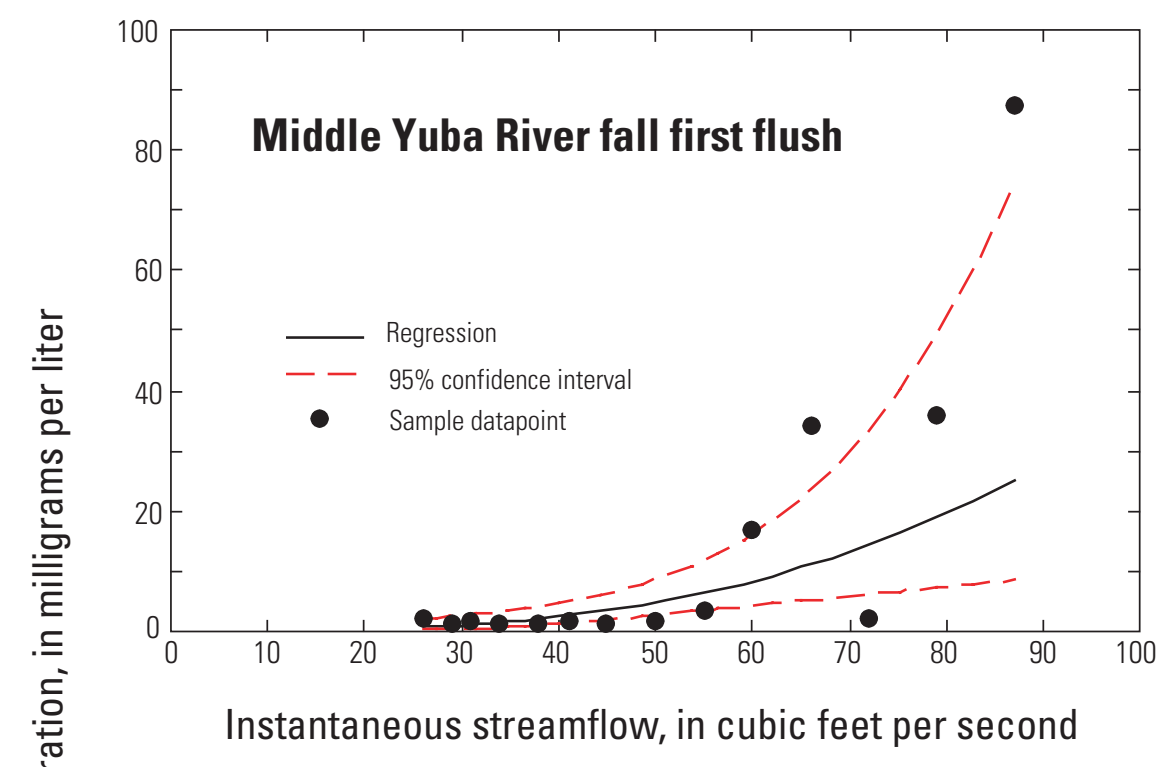

c

Figure 11. Continued. 


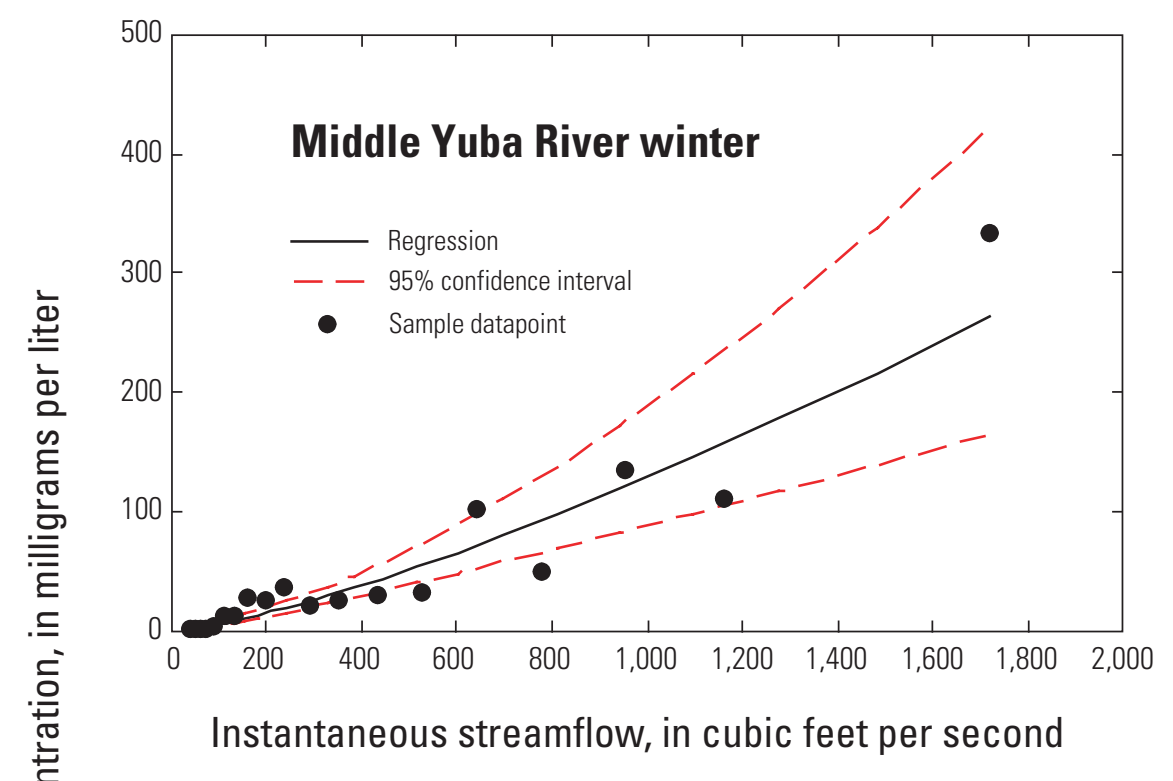

Figure 11. Continued. 


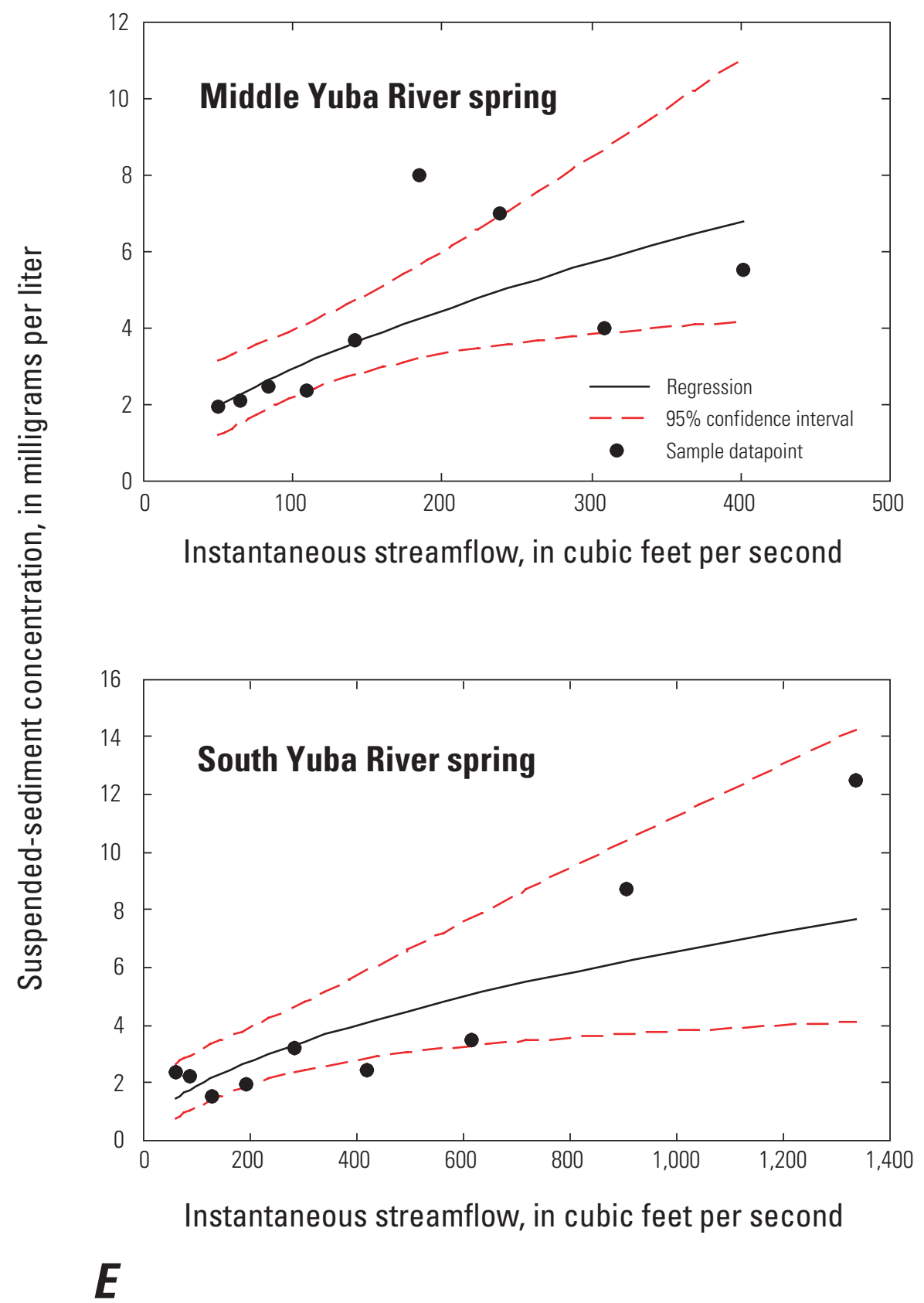

Figure 11. Continued. 
Table 4. Regression equation form and statistics for gaging stations in the Middle Yuba and South Yuba Rivers in the upper Yuba River watershed, California.

[Note: Regression variables, which include suspended-sediment concentration and streamflow, were converted to base-10 logarithms. $r^{2}$, coefficient of determination. $a$ is the $\mathrm{Y}$ intercept and $\mathrm{b}$ is the regression coefficient in equation 1. N, number of data points: Data points were used to determine group-averaged dataset; group-averaged data points were used in the regression analysis]

\begin{tabular}{|c|c|c|c|c|c|c|c|c|c|}
\hline & a & $\mathrm{b}$ & $r^{2}$ & $\begin{array}{c}\text { Standard } \\
\text { error }\end{array}$ & $P$ value & $\begin{array}{c}\mathrm{F} \\
\text { statistic }\end{array}$ & $\begin{array}{l}\text { Critical F } \\
\text { statistic }\end{array}$ & ${ }^{6} \mathrm{~N}$ & $\begin{array}{l}{ }^{7} \mathrm{~N} \text { (group- } \\
\text { averaged) }\end{array}$ \\
\hline \multicolumn{10}{|c|}{ Middle Yuba River (MYG, Station ID 11410000) } \\
\hline Average $^{1}$ & -1.776 & 1.278 & 0.95 & 0.165 & 0.000 & 326 & 1.4 & 675 & 19 \\
\hline Summer/fall ${ }^{2}$ & -0.602 & 0.516 & 0.28 & 0.125 & 0.050 & 5 & 1.5 & 135 & 14 \\
\hline First flush ${ }^{3}$ & -4.377 & 2.987 & 0.60 & 0.423 & 0.001 & 18 & 1.5 & 154 & 14 \\
\hline Winter $^{4}$ & -1.838 & 1.317 & 0.91 & 0.207 & 0.000 & 178 & 1.4 & 371 & 19 \\
\hline Spring snowmelt ${ }^{5}$ & -0.736 & 0.602 & 0.65 & 0.145 & 0.008 & 13 & 1.6 & 174 & 9 \\
\hline \multicolumn{10}{|c|}{ South Yuba River (SYG, Station ID 11417500) } \\
\hline Average $^{1}$ & -2.066 & 1.221 & 0.87 & 0.310 & 0.000 & 120 & 1.4 & 698 & 20 \\
\hline Summer/fall ${ }^{2}$ & -1.548 & 1.024 & 0.57 & 0.209 & 0.002 & 16 & 1.5 & 127 & 14 \\
\hline First flush ${ }^{3}$ & -3.127 & 1.945 & 0.79 & 0.383 & 0.000 & 40 & 1.5 & 145 & 12 \\
\hline Winter ${ }^{4}$ & -2.750 & 1.460 & 0.91 & 0.273 & 0.000 & 184 & 1.4 & 380 & 20 \\
\hline Spring snowmelt ${ }^{5}$ & -0.798 & 0.538 & 0.67 & 0.186 & 0.007 & 20 & 1.6 & 165 & 9 \\
\hline
\end{tabular}

'Used all data except outliers. ${ }^{2}$ Used all data collected from June through November except outliers and first flush event data. ${ }^{3}$ Used all data collected from June through November except outliers. ${ }^{4}$ Used all data collected from December through March except outliers. ${ }^{5}$ Used all data collected from April through May except outliers.

${ }^{6}$ Number of data points used to determine group-averaged dataset. ${ }^{7}$ Number of group-averaged data points used in regression analysis. 
The accuracy of seasonal suspended-sediment rating curves was assessed based on 95-percent confidence intervals for predicted values (fig.11A-E) and summary statistics (table 4). Confidence intervals denote a range around the predicted value where the "true" value can be expected with a given level of certainty, which is 95 percent in this case, and the confidence interval width indicates uncertainty. The first flush regressions display the widest confidence intervals, and therefore the predicted suspended-sediment concentrations have the greatest associated uncertainty. The confidence intervals for the summer/fall and spring snowmelt rating curves are greater than those for the winter and average curves indicating greater accuracy for the winter and average curves.

The following is a synopsis of the summary statistics presented in table 4 . The p value represents the probability of error associated in accepting the predicted results as true. Higher $\mathrm{p}$ values indicate less confidence in the regression as a reliable indicator of the relation between suspended-sediment concentration and streamflow. Typically, $\mathrm{p}$ values less than or equal to 0.05 are considered borderline statistically significant, $\mathrm{p}$ values less than or equal to 0.01 commonly are considered statistically significant, and $\mathrm{p}$ values less than or equal to 0.001 often are considered highly significant. The total variation in predicted suspended-sediment concentrations accounted for by the regression equations is given by $\mathrm{r}^{2}$, which can also be used as a measure of the strength of the regression relation. The standard error is an overall indication of the accuracy with which the regression predicts the dependence of suspended-sediment concentration on streamflow; however, the magnitude of the standard error is proportional to the magnitude of the dependent variable. Thus this statistic cannot be used to compare the accuracies of several of the regressions. The $\mathrm{p}$ values of all the regressions listed in table 4 were 0.05 or less, indicating statistical significance. In addition, the $\mathrm{F}$ statistic was greater than the critical $\mathrm{F}$ (alpha $=5$ percent) for all regressions in table 4 , providing further evidence of statistical significance. The $\mathrm{r}^{2}$ values for the first flush and spring snowmelt regressions for the Middle Yuba and South Yuba Rivers generally were lower than those for the average and winter regressions; the $r^{2}$ values for the summer/fall regressions were extremely low. Consequently, the average and winter regressions have a greater likelihood for predicting suspended-sediment concentrations closest to the true value.

\section{Bed Load}

\section{Bed-Load Rating Curves}

Bed-load rating curves (fig. 12) indicate that the Middle Yuba River has greater transport capacity (the ability to transport bed load) than the South Yuba River for a given instantaneous streamflow, even though bed material at the Middle Yuba River (11410000) gage site (fig. 7) is coarser because of deposition of fine-grained bed material in upstream reservoirs. The greater transport capacity at the Middle Yuba River (11410000) gage, compared with that at the South Yuba River (11410000) gage, can be attributed to a narrower and deeper channel that results in higher streamflow velocities (fig. 8) and to a smaller component of form drag that affects bed-shear stresses. The high slopes of the velocity-streamflow relations (fig. 8) further demonstrate that the Middle Yuba and South Yuba Rivers experience a rapid increase in capacity and competence (the size of the largest particle a stream can entrain under any given set of hydraulic conditions) with increasing streamflow.

\section{Shady Creek Bed-Load Measurements}

The accuracy of predicted bed-load rating curves was assessed using bed-load measurements collected in Shady Creek, a tributary to the South Yuba River that has been severely impacted by hydraulic mining (fig. 13). Shady Creek bed-load rating curves, a comparison of bed-load measurements and predicted bed-load transport rates, and grain-size distributions of bed-load samples are presented in figure 14 , table 5 , and figure 15 respectively. 


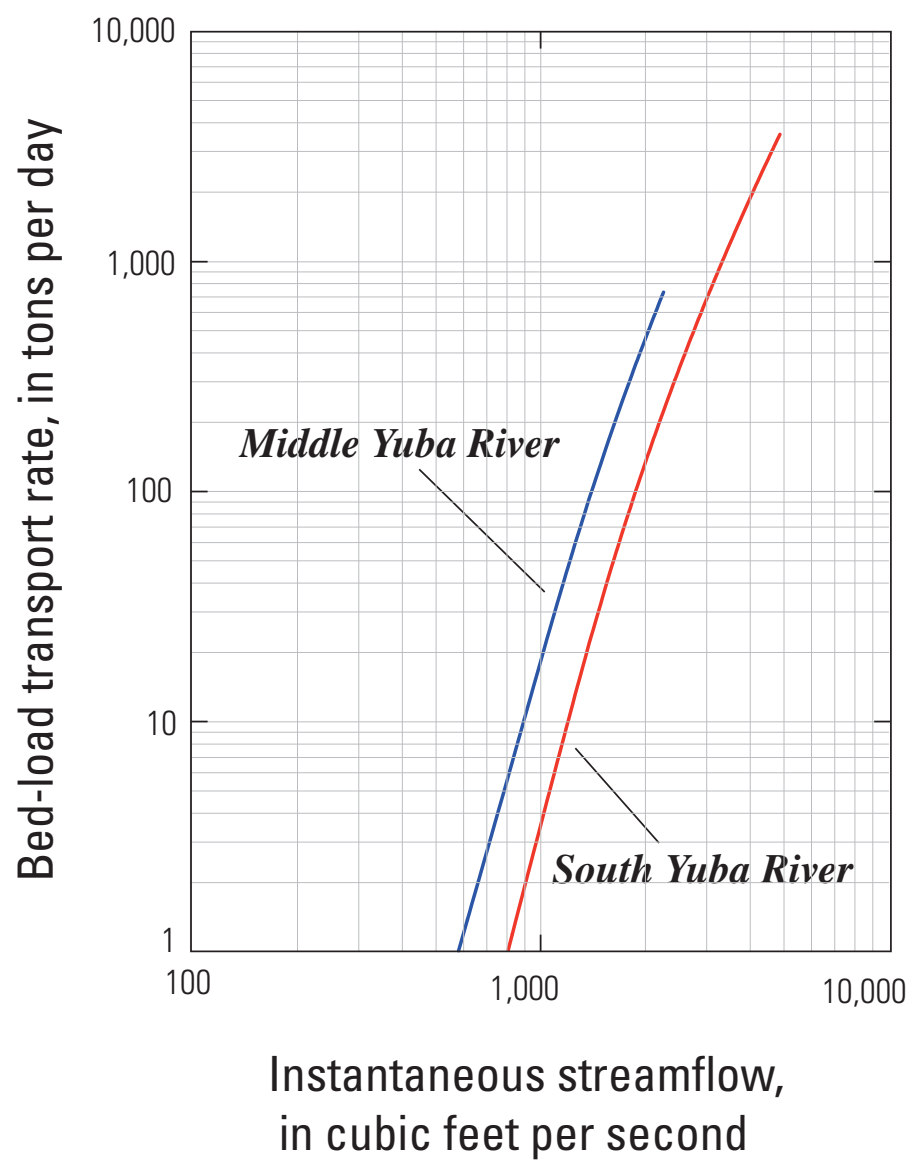

Figure 12. Relation of bed-load transport to instantaneous streamflow for the Middle Yuba River (11410000) and South Yuba River (11417500) gaging stations in the upper Yuba River watershed, California.

Bed-load rating curves were developed using an empirical transport model for mixed-size sediment (Wilcock and Crowe, 2003). Note that the bed-load transport was developed only for the range of flows observed during the study period from 2001 to 2003. 


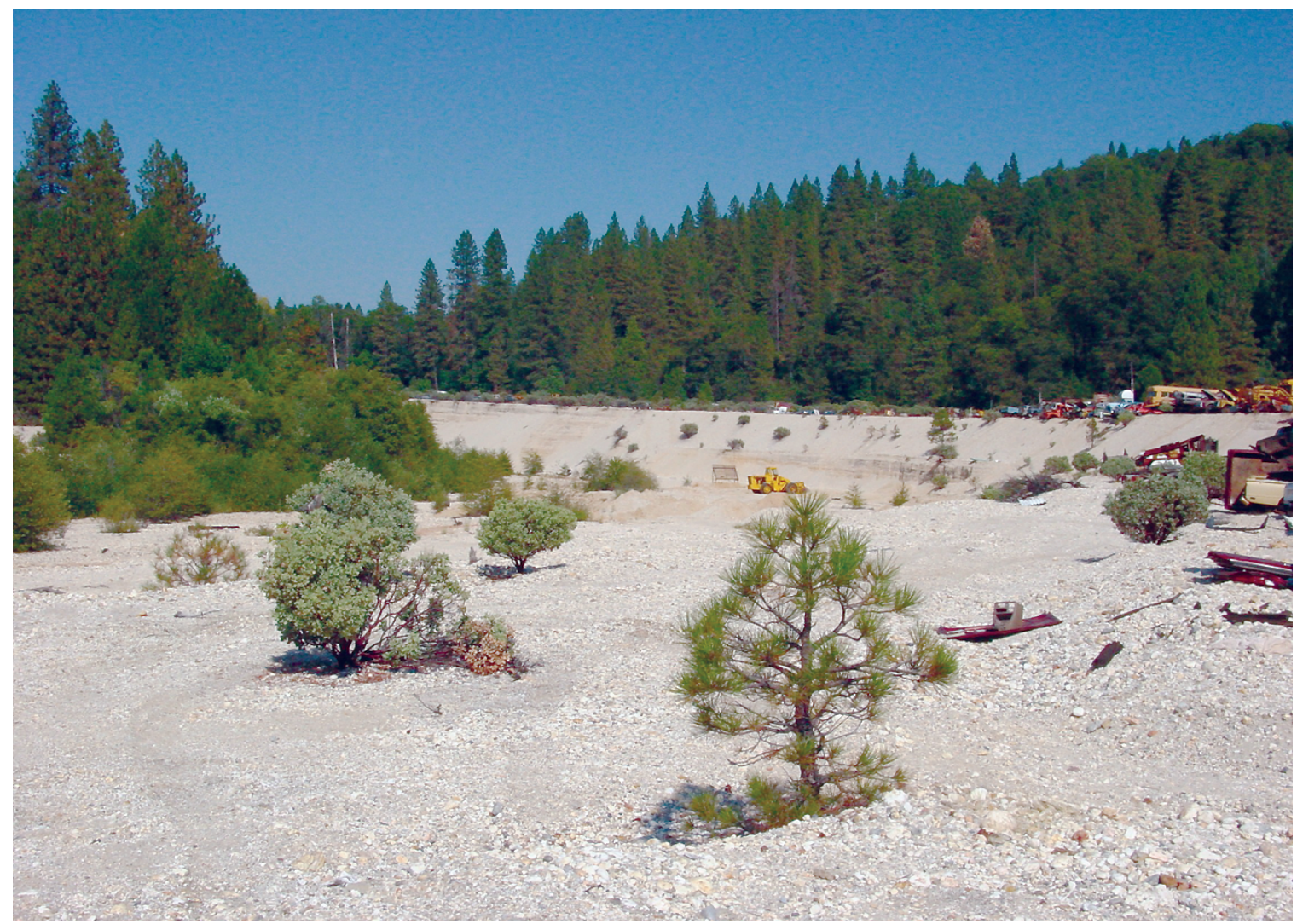

Figure 13. Extensive volumes of historical hydraulic-mining sediment are located in Shady Creek, a tributary to the South Yuba River in the upper Yuba River watershed, California.

View is looking upstream along the left bank. 


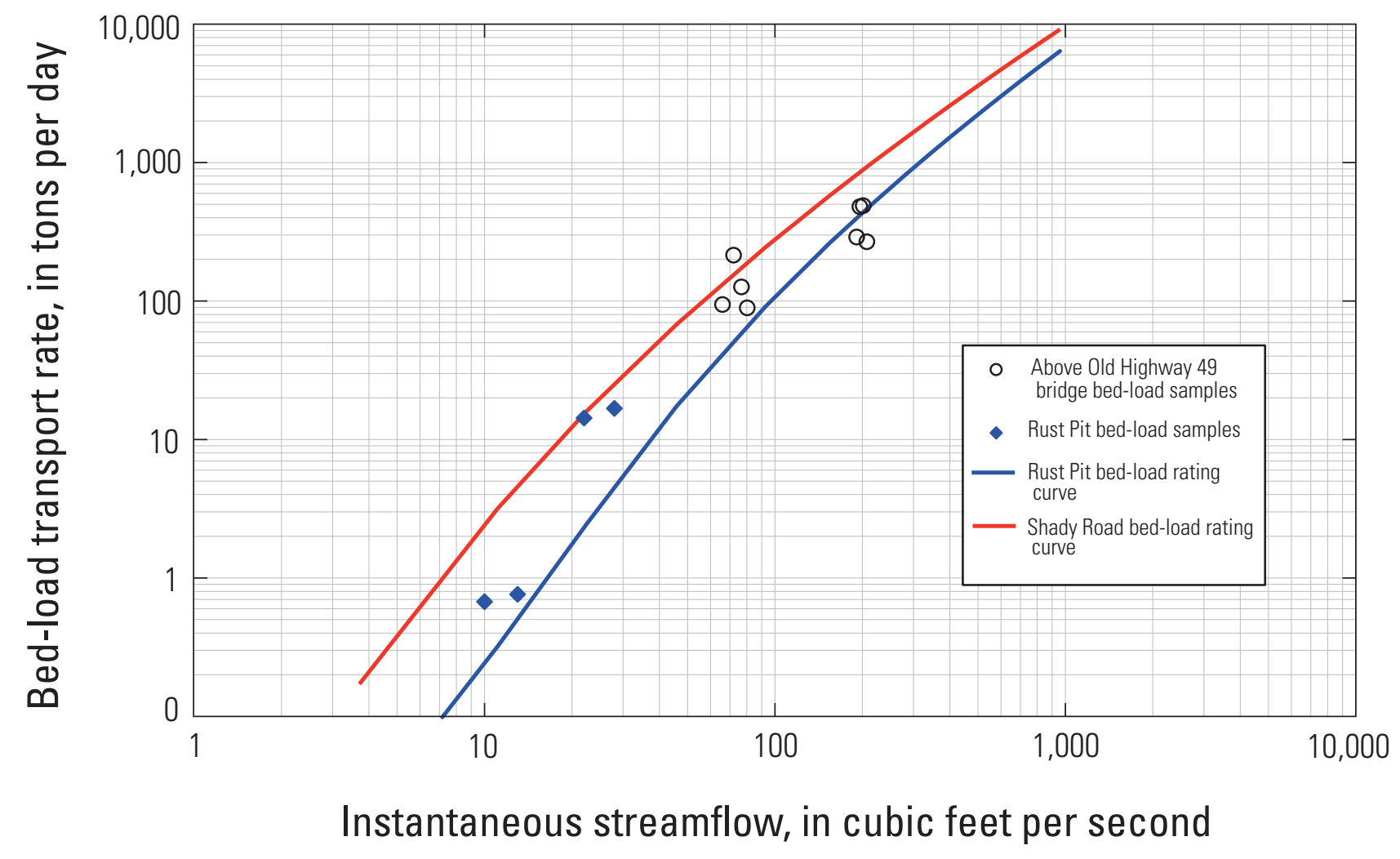

Figure 14. Relation of bed-load transport and instantaneous streamflow, and bed-load measurements for bed-load sampling sites on Shady Creek, a tributary to the South Yuba River in the upper Yuba River watershed, California. See figure 6 for site locations. 
Table 5. Measured bed load and predicted bed-load transport rates for two sites along Shady Creek in the upper Yuba River watershed, California.

[See figure 6 for location of sampling sites. $\mathrm{ft}^{3} / \mathrm{s}$, cubic feet per second; tons/day, tons per day]

\begin{tabular}{|c|c|c|c|c|c|c|c|c|}
\hline \multirow[b]{2}{*}{ Sampling location } & \multirow[b]{2}{*}{$\begin{array}{l}\text { Sample } \\
\text { number }\end{array}$} & \multirow[b]{2}{*}{ Date } & \multirow[b]{2}{*}{ Time } & \multirow[b]{2}{*}{$\begin{array}{c}\text { Streamflow } \\
\left(\mathrm{ft}^{3} / \mathrm{s}\right)\end{array}$} & \multirow{2}{*}{$\begin{array}{c}\text { Measured } \\
\text { bed-load } \\
\text { transport } \\
\text { (tons/day) }\end{array}$} & \multicolumn{2}{|c|}{$\begin{array}{c}\text { Predicted bed-load } \\
\text { transport rates } \\
\text { (tons/day) }\end{array}$} & \multirow{2}{*}{$\begin{array}{c}\text { Ratio } \\
\text { (predicted/ } \\
\text { measured) }\end{array}$} \\
\hline & & & & & & $\begin{array}{l}\text { Rust Pit } \\
\text { rating } \\
\text { curve }\end{array}$ & $\begin{array}{l}\text { Shady } \\
\text { Road } \\
\text { rating } \\
\text { curve }\end{array}$ & \\
\hline \multirow[t]{4}{*}{ Rust Pit } & RP-1a & $02 / 17 / 02$ & 09:00 & 10 & 0.7 & 0.2 & & 29 \\
\hline & RP-1b & $02 / 17 / 02$ & 09:10 & 13 & 0.8 & 0.5 & & 63 \\
\hline & RP-2a & $04 / 28 / 03$ & $11: 20$ & 22 & 14.3 & 2.3 & & 16 \\
\hline & $\mathrm{RP}-2 \mathrm{~b}$ & 04/28/03 & $11: 30$ & 28 & 16.8 & 4.6 & & 27 \\
\hline \multirow[t]{8}{*}{ Above Old Hwy 49 Bridge } & $\mathrm{H} 49-1 \mathrm{a}$ & $02 / 25 / 04$ & $11: 15$ & 191 & 289.9 & & 817.3 & 282 \\
\hline & $\mathrm{H} 49-1 \mathrm{~b}$ & $02 / 25 / 04$ & $11: 50$ & 196 & 480.5 & & 817.3 & 170 \\
\hline & $\mathrm{H} 49-2 \mathrm{a}$ & $02 / 25 / 04$ & $14: 40$ & 201 & 487.9 & & 980.2 & 201 \\
\hline & $\mathrm{H} 49-2 \mathrm{~b}$ & $02 / 25 / 04$ & $15: 09$ & 207 & 267.7 & & 980.2 & 366 \\
\hline & $\mathrm{H} 49-3 \mathrm{a}$ & 02/26/04 & $15: 40$ & 66 & 94.2 & & 134.4 & 143 \\
\hline & $\mathrm{H} 49-3 \mathrm{~b}$ & 02/26/04 & $16: 16$ & 72 & 214.4 & & 134.4 & 63 \\
\hline & $\mathrm{H} 49-4 \mathrm{a}$ & 02/26/04 & $10: 01$ & 77 & 126.3 & & 224.5 & 178 \\
\hline & $\mathrm{H} 49-4 \mathrm{~b}$ & 02/26/04 & $10: 19$ & 80 & 89.2 & & 224.5 & 252 \\
\hline
\end{tabular}

${ }^{1}$ Bed-load transport rates at the Above Old Hwy 49 Bridge site were predicted using the Shady Road rating curve 


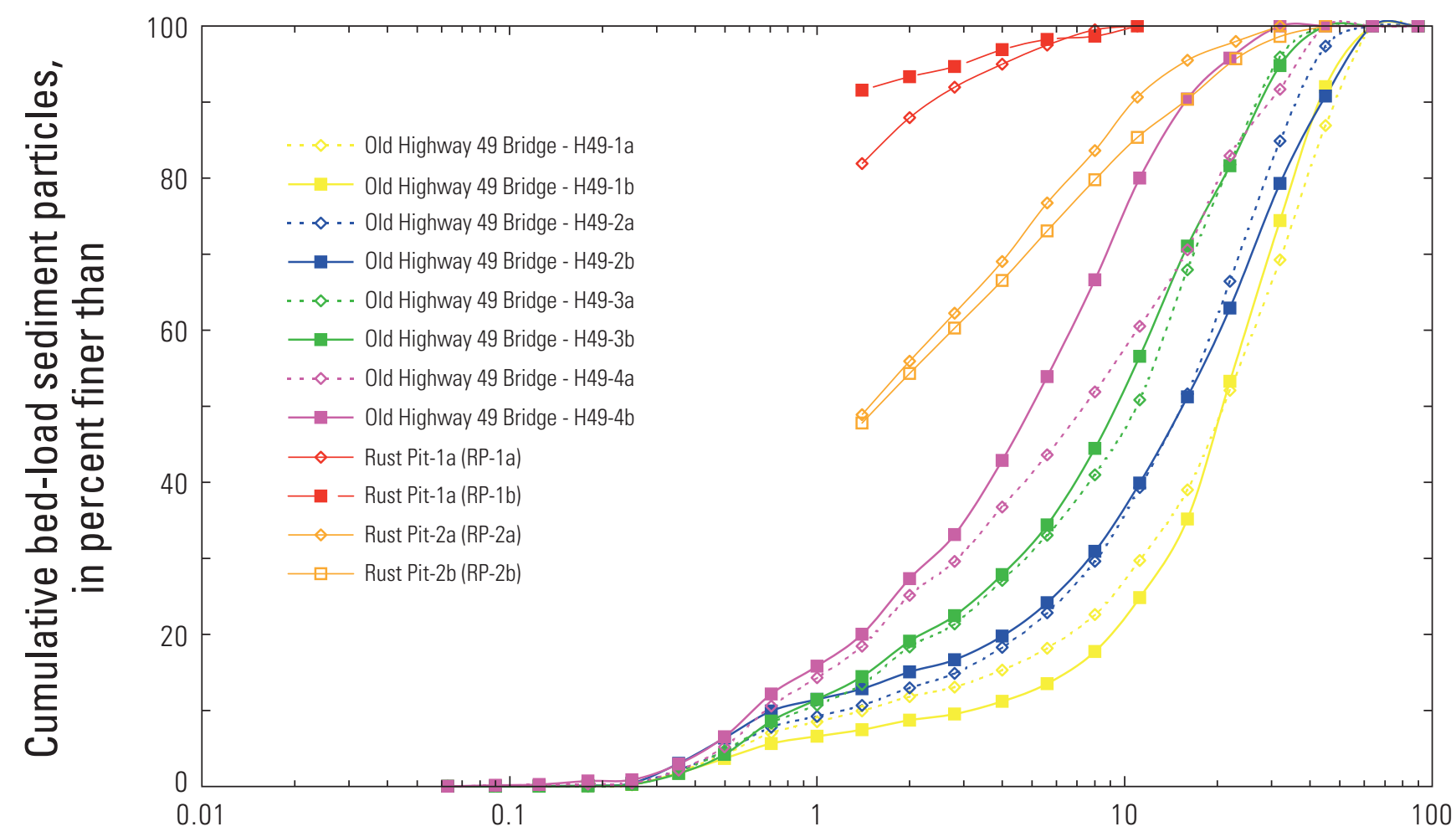

Particle size, in millimeters

Figure 15. Cumulative grain-size distributions for bed-load samples collected on Shady Creek, a tributary to the South Yuba River in the upper Yuba River watershed, California. The fraction of the bed-load sample from Rust Pit consisting of grains less than 1.4 millimeter was not sieved. Paired samples are indicated by matching colors. The order of collection of the pairs is indicated by "a" and "b" labels. See figure 6 for site locations and table 5 for information about paired samples. 
Shady Creek bed-load rating curves were developed for two locations (Rust Pit and Shady Road, fig. 6). Subsequent to developing the rating curves, sites were chosen for bed-load measurements. Low streamflow conditions were measured at the Rust Pit wading site and higher streamflow conditions were measured at the Old Hwy 49 Bridge site (fig. 6). Predicted bedload transport at the Shady Road site was inferred to be representative of bed-load transport at the Old Hwy 49 Bridge site; therefore, the Shady Road rating curve was used to estimate bed-load transport at the Old Hwy 49 Bridge site. Use of the Shady Road rating curve to estimate bed-load transport at the Old Hwy 49 Bridge site was justified based on the equation of continuity and the character of the channel between the two sites. Downstream of the Shady Road site, the channel transitions into a narrower, steeper, bedrock channel with negligible channel storage; therefore following the laws of conservation, bed-load transported past the Shady Road site subsequently passes the Old Hwy 49 Bridge.

Overall, the bed-load measurements agreed well with predicted curves; bed-load measurements were generally within the bounds of the bed-load rating curves (fig. 14). Grain-size distributions for paired bed-load samples agreed well; sediment values were generally within 10 percent of each other (fig. 15). However, transport rates at the Old Hwy 49 site were generally overpredicted and transport rates were generally underpredicted for the Rust Pit site (table 5).

\section{Sediment Transport}

There are three ways of defining total sediment discharge, the sum of all sediment passing a gaging station per unit time. (1) Total sediment discharge may be divided into fine-grained material and bed-material fractions. Fine-material discharge consists of particles finer than those normally found in the streambed. Bed-material discharge is composed of particles typically found in considerable quantity in the streambed. (2) Total sediment discharge may be divided into suspended-sediment, whose weight is entirely supported by the surrounding fluid, and into bed load, whose weight is supported primarily by the streambed. (3) Total sediment discharge may also be divided into sampled and unsampled sediment discharge. Owing to physical limitations of depth-integrating suspended-sediment samplers, samples are only collected from the water surface to within $0.3 \mathrm{ft}$ of the streambed. Sampled sediment discharge consists of both fine material and bed material transported in suspension greater than $0.3 \mathrm{ft}$ above the streambed. Unsampled sediment discharge (unsampled by the bed-load sampler) consists of both fine material and bed material transported in suspension less than $0.3 \mathrm{ft}$ above the streambed and bed material transported as bed load. In this report, total sediment discharge equates to the sum of sampled suspended-sediment discharge and estimated bed-load discharge.

\section{Annual Sediment Discharge}

Annual sediment discharge was calculated at the Middle Yuba River (11410000) gage and South Yuba River (11417500) gage for water years 2001, 2002 and 2003 (table 6). Suspendedsediment discharge was calculated using seasonal suspendedsediment rating curves and mean daily streamflow, whereas bed-load discharge was calculated using the flow-duration sediment transport method (Glysson, 1987), which employed bedload rating curves and 15-minute streamflow data. 
Table 6. Annual sediment discharge and bed-load estimates for gaging stations on the Middle Yuba and South Yuba Rivers in the upper Yuba River watershed, California.

[Annual suspended-sediment discharge estimated using seasonal suspendedsediment rating curves. Annual bed-load discharge estimated using mixedsediment model (Wilcock and Crowe, 2003). Total annual sediment discharge equals annual suspended-sediment discharge plus annual bed-load discharge. tons $/ \mathrm{mi}^{2}$, tons per square mile; $\mathrm{mi}^{2}$, square mile]

\begin{tabular}{|c|c|c|c|c|}
\hline Year & $\begin{array}{c}\text { Annual } \\
\text { suspended- } \\
\text { sediment } \\
\text { discharge } \\
\text { (tons) }\end{array}$ & $\begin{array}{c}\text { Annual } \\
\text { bed-load } \\
\text { discharge } \\
\text { (tons) }\end{array}$ & $\begin{array}{c}\text { Total } \\
\text { annual } \\
\text { sediment } \\
\text { discharge } \\
\text { (tons) }\end{array}$ & $\begin{array}{c}\begin{array}{c}\text { Annual } \\
\text { sediment } \\
\text { yield (tons/ } \\
\left.\mathrm{mi}^{2}\right)\end{array} \\
\end{array}$ \\
\hline \multicolumn{5}{|c|}{$\begin{array}{c}\text { South Yuba River (SYG, Station ID } 11417500 \\
\text { [drainage area } 308 \mathrm{mi}^{2} \text { ]) }\end{array}$} \\
\hline 2001 & 730 & 1 & 731 & 2 \\
\hline 2002 & 4,700 & 16 & 4,716 & 15 \\
\hline 2003 & 7,600 & 89 & 7,689 & 25 \\
\hline $\begin{array}{c}\text { Average annual } \\
\text { (sediment } \\
\text { discharge) }\end{array}$ & & & 4,379 & 14 \\
\hline \multicolumn{5}{|c|}{$\begin{array}{c}\text { Middle Yuba River (MYG, Station ID } 11410000 \\
\text { [drainage area } 198 \mathrm{mi}^{2} \text { ]) }\end{array}$} \\
\hline 2001 & 150 & 0 & 150 & 1 \\
\hline 2002 & 910 & 3 & 913 & 5 \\
\hline 2003 & 2,000 & 19 & 2,019 & 10 \\
\hline $\begin{array}{c}\text { Average annual } \\
\text { (sediment } \\
\text { discharge) }\end{array}$ & & & 1,027 & 5 \\
\hline
\end{tabular}

Estimated annual sediment discharges at the Middle Yuba River (11410000) gage were significantly lower than those at the South Yuba River (11417500) gage even when compared by drainage area. The main contributing factor to the difference in sediment loads is that 88 percent of the Middle Yuba River watershed lies upstream of Log Cabin and Our House Reservoirs. This effect is compounded by significant flow diversions above the Middle Yuba River (11410000) gage, which resulted in a median daily flow for the project period of $57 \mathrm{ft}^{3} / \mathrm{s}$ at the Middle Yuba River (11410000) gage compared with $98 \mathrm{ft}^{3} / \mathrm{s}$ at the South Yuba River (11417500) gage. Because the South Yuba River has higher flows and no man-made restrictions to sediment movement in the lower basin, it is able to transport a greater and coarser sediment load.
In water years 2001, 2002, and 2003, the Middle Yuba River transported only 9, 14, and 31 percent, respectively, of the load transported by the South Yuba River at the gaging stations. The increase of sediment discharge in water year 2003 at the Middle Yuba River (11410000) gage, relative to that at the South Yuba River (11417500) gage, may reflect the influence of spill events at Log Cabin and Our House Dam reservoirs. Our House Reservoir, the larger of the two facilities, spilled only 1 day in 2001, 11 days in 2002, and 21 days in 2003. Because anomalously high suspended-sediment concentrations (fig. 9B inset) can occur during spill events, annual suspended-sediment discharge may be elevated during years in which these reservoirs spill. Storm sampling in December 2002 and March 2003 indicates that the first spill event in December 2002 flushed a fraction of suspendable-sized reservoir sediment impounded within Log Cabin and Our House Dam reservoirs. As the volume of suspendable-sized reservoir sediment was depleted, subsequent spills, such as occurred in March 2003, contributed smaller amounts of sediment.

The percentage of annual sediment discharge transported as bed load was less than 1 percent throughout the study period, which was quite low and unexpected given the abundance of bed material available for transport. Significant volumes of hydraulic-mining sediment remain stored in smaller upland tributary channels. The mining sediment tends to be finer grained and therefore more transportable than bed material derived from non-mining sources (James, 2005). Consequently, stored sediment from hydraulic mining represents a significant sediment source in the Middle Yuba and the South Yuba Rivers (Curtis and others, 2005).

It is important to note that 88 percent of the Middle Yuba River watershed lies upstream of Log Cabin and Our House Reservoirs; therefore most of the source area for coarser sediment in the Middle Yuba River was cutoff by the reservoirs, which subsequently resulted in decreased bed-load transport and coarsening of the channel bed at the Middle Yuba River (11410000) gage (fig. 7). However, the low bed-load transport rates at the South Yuba River (11417500) gage remain an anomaly (table 6). Below-average to average precipitation conditions occurred throughout the project period, which likely influenced the low percentage of annual sediment discharge transported as bed load. During above-average water years, the percentage of bed load may change as greater streamflows mobilize larger volumes of bed material. 
A better representation of the long-term average bed-load transport can be made using estimates of bed load transported by the Feather River (fig. 1). The Feather River is adjacent to the Yuba River and has a similar land-use history including hydraulic mining and timber harvesting. On the basis of deposition in Lake Oroville, long-term average sediment discharge for the Feather River from 1902 to 1962 consisted of approximately 13 percent bed load (Porterfield and others, 1978).

Annual suspended-sediment discharges reported here are compared with those published in the USGS annual data reports (table 7). Annual suspended-sediment discharges published in USGS annual data reports were estimated using a software package called Graphical Constituent Loading Analysis System (GCLAS; http://oh.water.usgs.gov/gclas/). GCLAS is designed to compute mean daily suspended-sediment concentrations and mean daily sediment loads. Using suspended-sediment concentrations and mean daily streamflow, GCLAS implements a user-defined interpolation between suspended-sediment concentration data points to predict a continuous trace of mean daily suspended-sediment concentrations. A typical time series of concentration data includes one concentration data point every 1 to 3 days. Load computations are made by applying a mid-interval method to the concentration time series data, which involves interpolating concentrations during periods between data points. Options for interpolation are user-defined and include linear (preferred) or log-linear equations.

Table 7. Annual suspended-sediment discharge for gaging stations on the Middle Yuba (MYG) and South Yuba (SYG) Rivers in the upper Yuba River watershed, California. [GCLAS, Graphical Constituent Loading Analysis System, used for U.S. Geological Survey annual data reports (Rockwell and others, 2001; Smithson and others, 2002; Friebel and others, 2003). Percent difference is the difference between the GCLAS and rating curve estimates divided by the GCLAS estimate. Rating curve regression equations listed in table 4 for sample periods]

\begin{tabular}{|c|c|c|c|c|}
\hline \multirow[b]{2}{*}{$\begin{array}{l}\text { Water } \\
\text { year }\end{array}$} & \multirow[b]{2}{*}{ Sampling period } & \multicolumn{2}{|c|}{$\begin{array}{l}\text { Annual suspended- } \\
\text { sediment discharge }\end{array}$} & \multirow[b]{2}{*}{$\begin{array}{l}\text { Percent } \\
\text { difference }\end{array}$} \\
\hline & & $\begin{array}{l}\text { Estimated } \\
\text { using } \\
\text { GCLAS } \\
\text { (tons) }\end{array}$ & $\begin{array}{c}\text { Estimated } \\
\text { using } \\
\text { rating } \\
\text { curves } \\
\text { (tons) }\end{array}$ & \\
\hline \multicolumn{5}{|c|}{ South Yuba River (SYG, Station ID 11417500) } \\
\hline 2001 & $11 / 08 / 00-09 / 30 / 01$ & 1,500 & 690 & 54 \\
\hline 2002 & $10 / 01 / 01-06 / 30 / 02$ & 3,400 & 4,700 & -38 \\
\hline 2003 & $11 / 01 / 02-05 / 31 / 02$ & 7,700 & 7,500 & 3 \\
\hline \multicolumn{5}{|c|}{ Middle Yuba River (MYG, Station ID 11410000) } \\
\hline 2001 & $11 / 08 / 00-09 / 30 / 01$ & 140 & 140 & 0 \\
\hline 2002 & $10 / 01 / 01-06 / 30 / 02$ & 480 & 890 & -85 \\
\hline 2003 & $11 / 01 / 02-05 / 31 / 02$ & 2,400 & 1,900 & 21 \\
\hline
\end{tabular}

The two methods for estimating annual suspended-sediment discharge produced substantially different results (table 7). The difference in annual suspended-sediment discharge estimated using the seasonal rating curves and that estimated using GCLAS ranged from -85 to +21 percent for the Middle Yuba River and from -38 to +54 percent for the South Yuba River. The percent difference was generally greatest for water years that had below average precipitation (WY2001 and 2002); however, there was 0 percent difference for the Middle Yuba River in WY2001. Wetter conditions prevailed during WY2003, and the number of samples increased. The time series dataset for suspended-sediment concentrations in WY2003 included four storm sampling events. The increased number of samples collected during WY2003 likely improved the GCLAS estimates of sediment loads.

\section{Event-Based Suspended-Sediment Discharge}

A continuous time series of calibrated OBS data and seasonal suspended-sediment rating curves were used to evaluate event-based suspended-sediment transport. Calibration of the optical backscatter data required a relatively stable particle-size distribution. Over the range of flows represented in the calibration data sets ( 50 to $2,000 \mathrm{ft}^{3} / \mathrm{s}$ ), the fraction of fine-grained sediment (percent less than $0.063 \mathrm{~mm}$ ) remained quite high, varying from 73 to 99 percent, which indicates that fine-grained sediment dominates the suspended load. A plot of the ratio of suspended-sediment concentration to sensor output voltage as a function of suspended particles finer than $0.063 \mathrm{~mm}$ (fig. 16) has an essentially constant slope, illustrating the minimal effects of particle size on sensor calibration (fig. 17). At higher flows, as more sand goes into suspension, the effects of particle size likely increase; therefore, sensor calibrations indicate an increase in uncertainty with increasing streamflow, indicated by the large deviation outside the prediction interval by the confidence bounds at higher suspended-sediment concentrations (fig.17).

The accuracy of the calibrated OBS data was assessed using nonparametric prediction intervals and 95-percent confidence intervals. The nonparametric prediction interval (Helsel and Hirsch, 1992, p. 76) contains one standard deviation (68.26 percent) of the calibration dataset and represents essentially the same error prediction limits as the root mean square (RMS) error of prediction in ordinary least-squared regression, and the confidence intervals represent a range of predicted values where the true value can be expected to fall with 95 percent certainty. The smaller width of the prediction and confidence intervals for the Middle Yuba River calibration equation indicates greater accuracy than that for the South Yuba River calibration equation. In addition, confidence bounds increase with increasing concentration and sensor output voltage, indicating greater accuracy at low to moderate concentrations. 


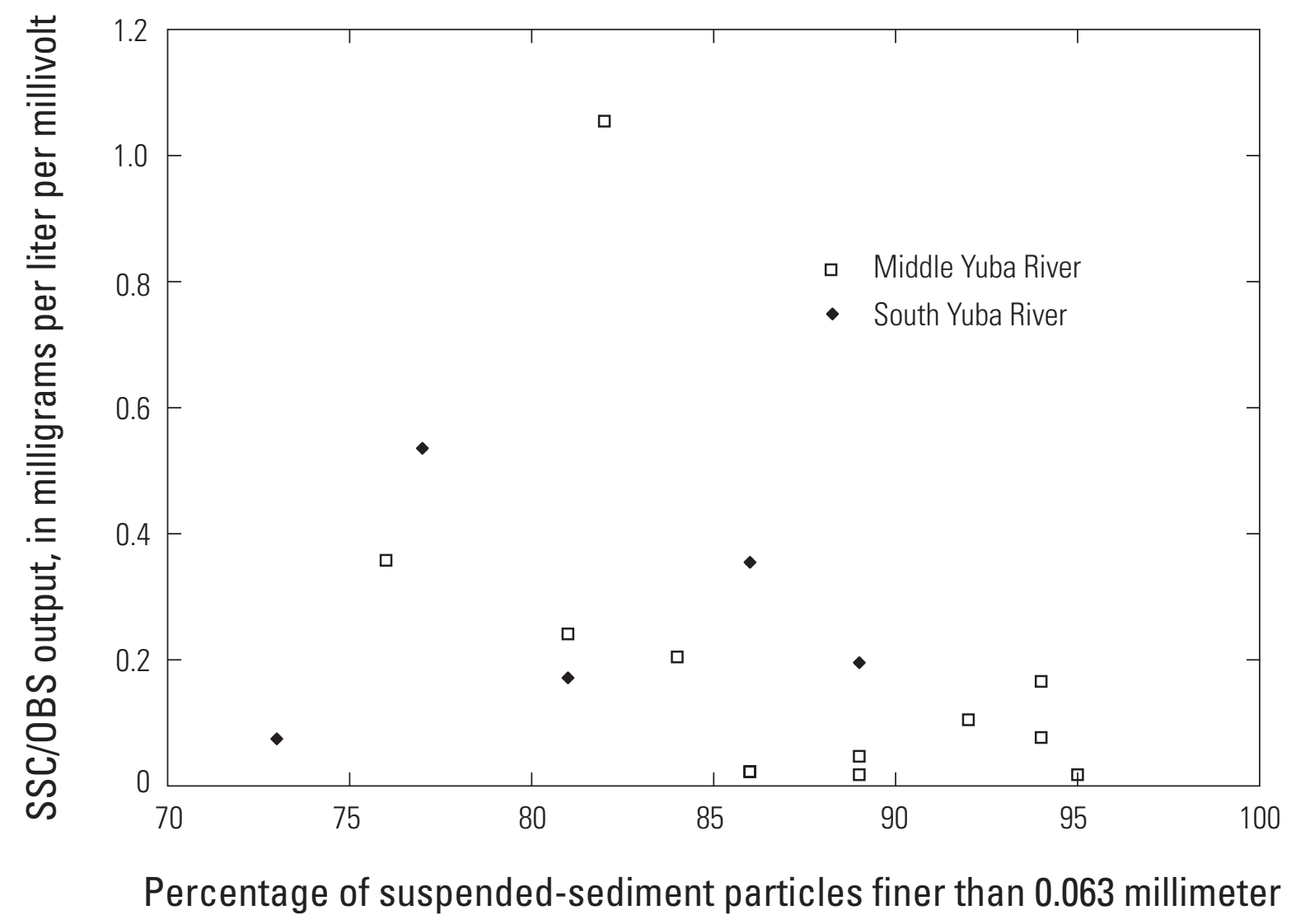

Figure 16. Ratio of suspended-sediment concentration to optical backscatter sensor output voltage as a function of suspended particles finer than 0.063 millimeter for two gaging stations:, Middle Yuba River (11410000) and South Yuba River (11417500). OBS, optical backscatter sensor; SSC, suspended-sediment concentration. 

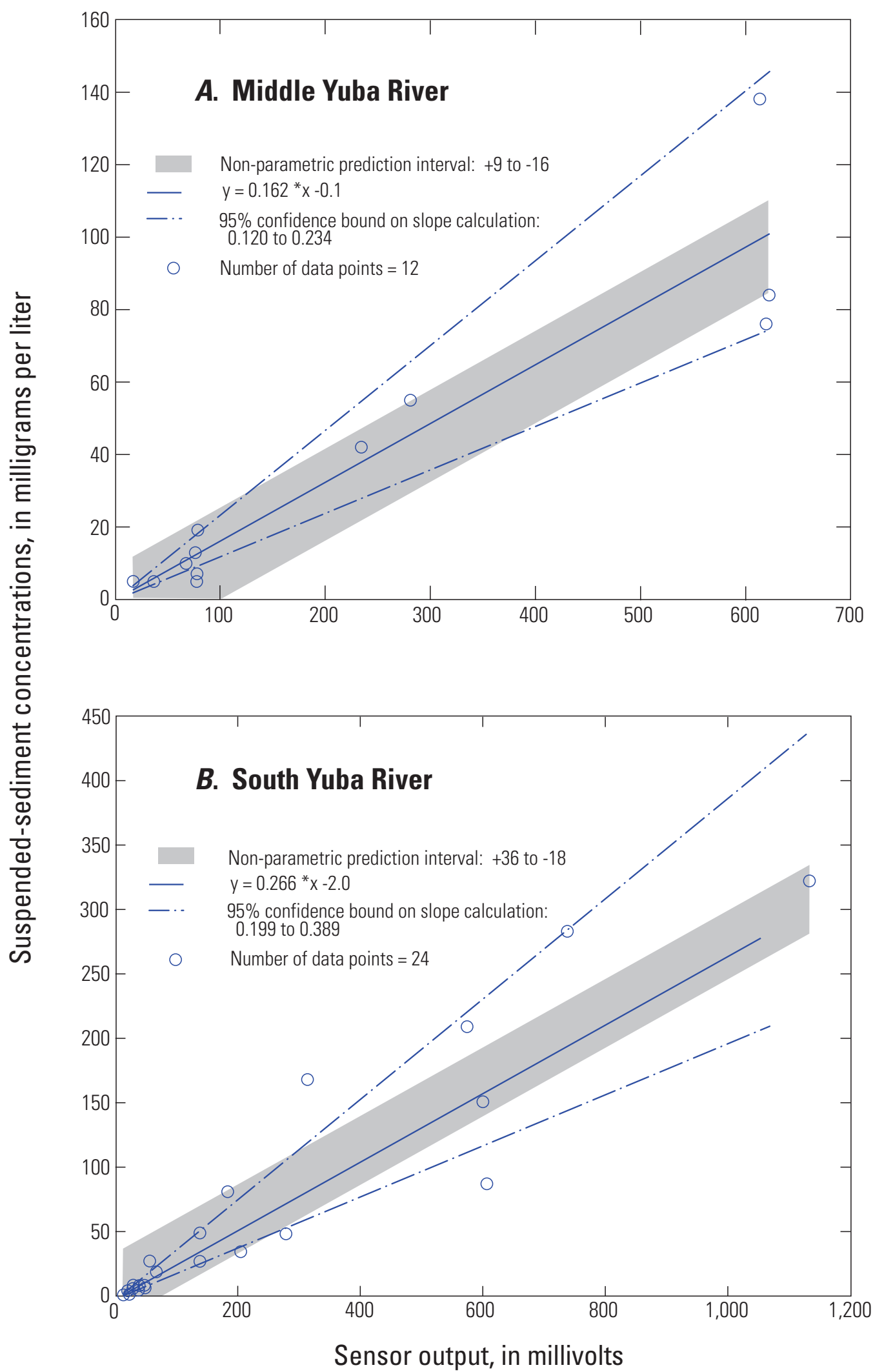

Figure 17. Relation of suspended-sediment concentration and optical backscatter sensor (OBS) output for two gaging stations in the upper Yuba River watershed, California. A, Middle Yuba River (11410000); B, South Yuba River (11417500). OBS, optical backscatter sensor. 
Calibrated OBS data and winter suspended-sediment rating curves were used to evaluate suspended-sediment transport for two moderate discharge events occurring during December 2002 at the Middle Yuba River (11410000) and South Yuba River (11417500) gages (table 8). Figure 18 shows streamflow and predicted suspended-sediment concentrations based on calibrated OBS output and winter rating curves. During the December 20-23, 2002 storm, the OBS registered delayed sediment peaks at both the Middle Yuba River (11410000) and South Yuba River (11417500) gages. The OBS sediment peaks occurred 5 hours after the streamflow peak at the Middle Yuba River (11410000) gage (fig. 18A) and almost 24 hours after the streamflow peak at the South Yuba River (11417500) gage (fig. 18B). Suspended-sediment transport estimated using the winter rating curve during the December 20-23, 2002, storm was 86 percent of that estimated using the calibrated OBS data at the Middle Yuba River (11410000) gage and only 50 percent of that estimated using the OBS data at the South Yuba River (11417500) gage (table 8). During the December 27-30, 2002 storm, the OBS registered early sediment peaks at both the Middle Yuba River (11410000) and South Yuba River (11417500) gages. The OBS sediment peaks occurred 2 hours before the streamflow peak at the Middle Yuba River (11410000) gage (fig. 18C) and 5 hours before the streamflow peak at the South Yuba River (11417500) gage (fig. 18D). Suspended-sediment transport during the December 27-30, 2002, storm, estimated using the winter rating curve, was nearly five times higher than that estimated using the OBS data for the Middle Yuba River (11417500) gage, whereas the two methods gave estimates within 13 percent for the South Yuba River (11410000) gage (table 8).

The percent difference ranged from 50 to -369 percent and an average of the four percent-difference values in table 8 is -79 percent. OBS is preferred over rating curves when eventbased suspended-sediment transport is assessed because the OBS data provide an independent, continuous time-series dataset with detailed information about the timing of sediment peaks and the duration of sediment loads, whereas the rating curve is dependent on the streamflow dataset. As a result, rating curves may misrepresent sediment transport in situations where the sediment transport does not mimic streamflow. In these situations, calibrated OBS data can provide a more accurate estimate of suspended-sediment transport.

Compared to the OBS data, the rating curves underestimated suspended-sediment discharge during the December 2023,2002 , storm characterized by lower streamflows and overestimated suspended-sediment discharge during the December 27-30, 2002, storm characterized by higher streamflows (table 8). This could indicate that the slope of the winter rating curves is too steep such that suspended-sediment concentrations are underpredicted at lower streamflows and overpredicted at higher streamflows (table 8). Alternatively, this may indicate a depletion of suspended sediment resulting in lower concentrations during the December 27-30, 2002, storm that were measured using the OBS but could have been misrepresented by the rating curves, which rely on the streamflow dataset.

Table 8. Event-based suspended-sediment discharge at gaging stations on the Middle Yuba and South Yuba Rivers in the upper Yuba River watershed, California.

[Percent difference is the difference between the OBS (optical backscatter sensor) and rating curve estimates divided by the OBS estimate. $\mathrm{ft}^{3} / \mathrm{s}$, cubic feet per second]

\begin{tabular}{|c|c|c|c|c|}
\hline \multirow[b]{2}{*}{ Storm events } & \multirow[b]{2}{*}{$\begin{array}{c}\text { Peak } \\
\text { streamflow } \\
\left(\mathrm{ft}^{3} / \mathrm{s}\right)\end{array}$} & \multicolumn{2}{|c|}{ Event-based suspended-sediment discharge } & \multirow[b]{2}{*}{$\begin{array}{c}\text { Percent } \\
\text { difference } \\
(\%)\end{array}$} \\
\hline & & $\begin{array}{l}\text { Estimated using OBS data }{ }^{1} \\
\text { (tons) }\end{array}$ & $\begin{array}{c}\text { Estimated using rating } \\
\text { curves }^{2} \\
\text { (tons) }\end{array}$ & \\
\hline \multicolumn{5}{|c|}{ Middle Yuba River (MYG, USGS Station ID 11410000) } \\
\hline December $20-23,2002$ & 346 & 21 & 18 & 14 \\
\hline December 27-30, 2002 & 995 & 64 & 300 & -369 \\
\hline \multicolumn{5}{|c|}{ South Yuba River (SYG, USGS Station ID 11417500) } \\
\hline December $20-23,2002$ & 984 & 200 & 100 & 50 \\
\hline December 27-30, 2002 & 1,980 & 520 & 590 & -13 \\
\hline
\end{tabular}

${ }^{1}$ Estimated using calibrated OBS data.

${ }^{2}$ Estimated using winter rating curves shown in table 4. 


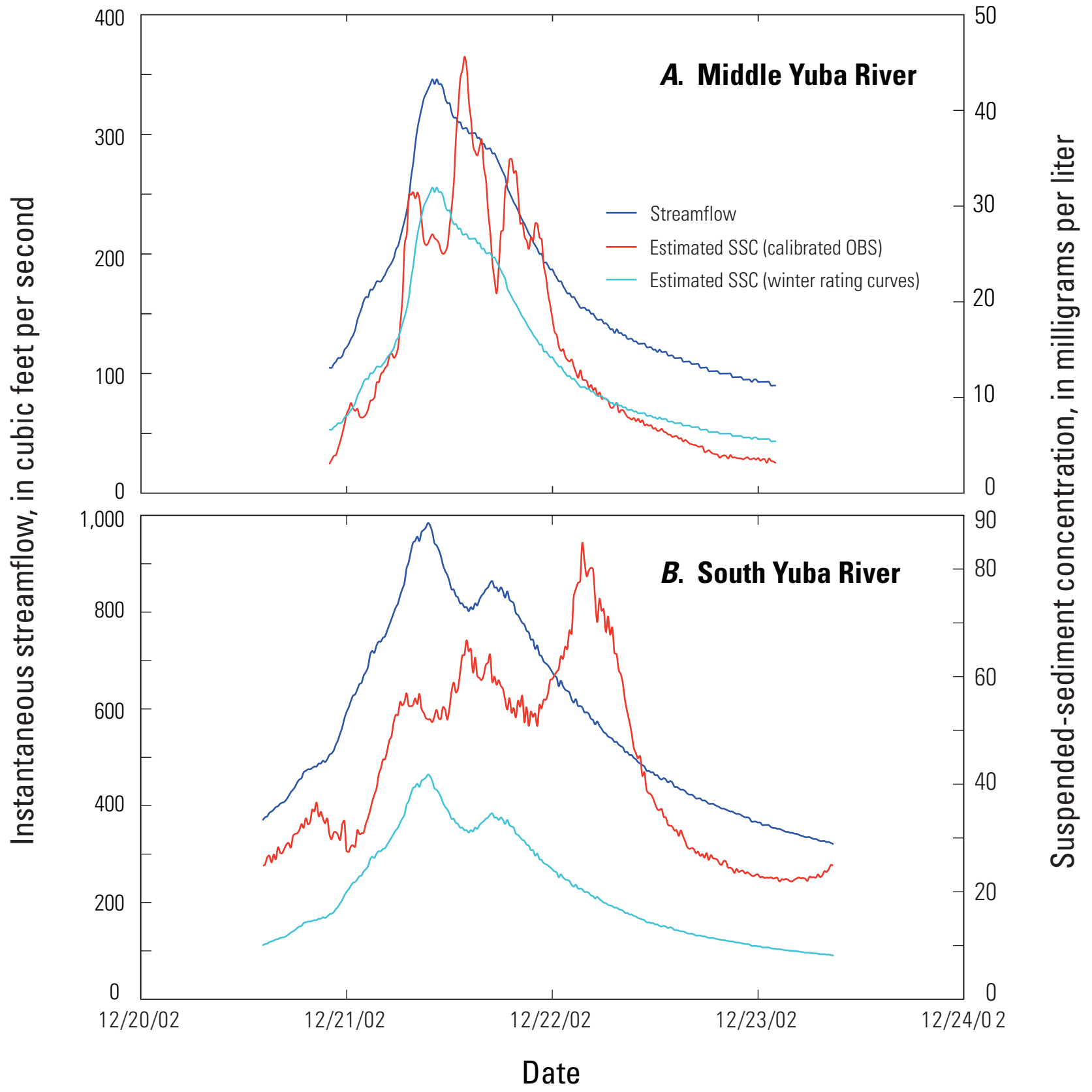

Figure 18. Instantaneous streamflow and suspended-sediment concentrations (SSC) during storm events at the Middle Yuba River (11410000) and South Yuba River (11417500) in the upper Yuba River watershed, California, (A,B) December 20 to 23, 2002, and (C,D) December 27 to $30,2002$. OBS, optical backscatter sensor. 


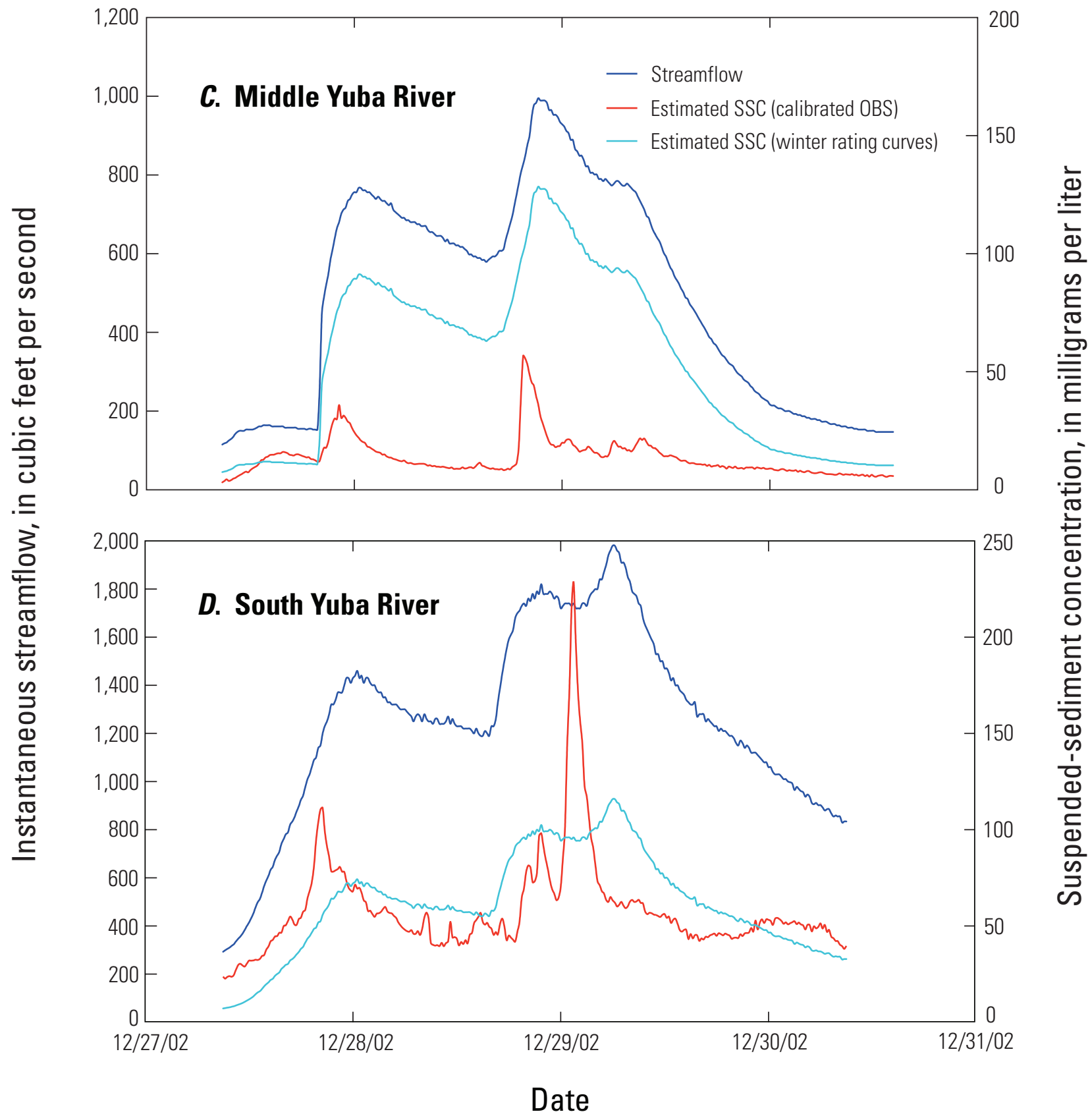

Figure 18. Continued. 


\section{Summary}

The purpose of this study was to characterize annual and event-based sediment transport in the upper Yuba River watershed during water years 2001, 2002, and 2003. Data collection included gaging streamflow and sampling suspended-sediment concentration at four upper Yuba River gaging stations: Middle Yuba River (11410000), South Yuba River (11417500), Yuba River below New Colgate Powerplant (11413700), and Yuba River below Englebright Dam (11418000). Suspendedsediment samples were collected 1 to 7 days per week at all gaging stations, depending on hydrologic conditions, and samples were collected at the Middle Yuba River (11410000) gage and South Yuba River (11417500) gage during four storms in water year 2003. Additional suspended-sediment samples were collected at the Middle Yuba River (11410000), South Yuba River (11417500), and Yuba River below Englebright Dam(11418000) gages for detailed grain-size analyses. Continuously recording optical backscatter sensors (OBS) were installed at the Middle Yuba River (11410000) gage and South Yuba River (11417500) gage to provide 15-minute time-series records of suspendedsediment concentration. Bed-load rating curves were developed for the Middle Yuba River (11410000) and South Yuba River (11417500) gage sites, and two sites on Shady Creek (Rust Pit and Shady Road) using an empirical bed-load transport relation (the Hopkins model); the accuracy of bed-load rating curves was assessed using bed-load measurements from Shady Creek, which agreed well with predicted curves. Finally, methods for estimating annual and event-based suspended-sediment discharge were compared.

Group-average suspended-sediment rating curves for the Middle Yuba River (11410000) and South Yuba River (11417500) gages describe average, summer/fall, first flush, winter, and spring snowmelt conditions. Variations in the slopes of the rating curves indicate changes in sediment supply throughout the water year. Under below-average and average precipitation conditions, such as occurred during the study period, sediment supply is greatest during the first flush of the water year; the rating curves for the first flush have the greatest slopes. Sediment supplies decreased following the first flush; thus, the slopes of the winter rating curves are lower than those of the first flush curves. The spring and summer/fall rating curves had the lowest slopes, indicating low supply conditions.

Although summary statistics and confidence bounds indicate that the accuracy of individual rating curves varies considerably, p values (less than 0.05) and F statistics (greater than the critical $\mathrm{F}$ for alpha $=5$ percent) indicate statistical significance for all the suspended-sediment regressions. The $\mathrm{r}^{2}$ values for the first flush and spring snowmelt regressions generally were lower than those for the average and winter regressions; the $r^{2}$ values for the summer/fall regressions were extremely low. The first flush regressions display the widest confidence intervals, and therefore the predicted suspendedsediment concentrations have the greatest associated uncertainty. The confidence intervals for the summer/fall and spring snowmelt rating curves are greater than those for the winter and average curves indicating greater accuracy for the winter and average curves. Thus, the winter and average regressions have the greatest likelihood for predicting suspended-sediment concentrations closest to the true value.

Seasonal suspended-sediment rating curves were developed to aid in the calibration of a watershed-scale sediment transport model and to assess the magnitude and duration of sediment loads that may impact the viability of long-term fishintroduction strategies. The seasonal rating curves were used to estimate annual suspended-sediment loads during water years 2001, 2002, and 2003. These estimates were compared with previously published annual suspended-sediment loads estimated using an interpolation software package (GCLAS). The percent difference ranged from -85 to +54 percent and averaged -7.5 percent.

Event-based suspended-sediment loads were estimated using calibrated OBS data and seasonal rating curves for two storms during December 2002. The percent difference ranged from 50 to -369 percent and averaged -79 percent. Compared to the OBS data, the rating curves underestimated suspendedsediment transport during the December 20-23, 2002, storm characterized by lower streamflows and overestimated suspended-sediment transport during the December 27-30, 2002, storm characterized by higher streamflows. This may indicate that the slopes of the winter rating curves are too steep such that suspended-sediment concentrations are underpredicted at lower streamflows and overpredicted at higher streamflows. Alternatively, this may indicate a depletion of suspended-sediment resulting in lower concentrations during the December 27-30, 2002, storm that were measured using the OBS and misrepresented by the rating curves, which rely on the streamflow dataset. The OBS data provided an independent continuous time-series dataset containing detailed information about the timing of sediment peaks and the duration of sediment loads; therefore the calibrated OBS estimates of suspended sediment transport is preferred over the rating curve estimates.

For 2001-2003, the estimated average annual sediment yield at the Middle Yuba River (11410000) gage (5 tons $/ \mathrm{mi}^{2}$ ) was significantly lower than that for the South Yuba River (11417500) gage (14 tons $/ \mathrm{mi}^{2}$ ); in both rivers, bed load represented less than 1 percent of the total annual load throughout the project period. Suspended sediment at both the Middle Yuba River (11410000) and South Yuba River (11417500) gages was typically greater than 85 percent silt and clay during water year 2003, and sand concentrations at the South Yuba River (11417500) gage were typically higher than those at the Middle Yuba River (11410000) gage for a given streamflow. Factors contributing to differences in sediment loads and grain-size distributions on the Middle Yuba and South Yuba Rivers include drainage area, flow diversions, and deposition of bed-material-sized sediment in Middle Yuba River reservoirs. Owing to its larger drainage area, higher flows, and absence of man-made structures that restrict sediment movement in the lower basin, the South Yuba River transports a greater and coarser sediment load. 
Rainfall-runoff conditions were below average during the first two years of this study and average during the last year. Because sediment transport is heavily influenced by extreme rainfall-runoff events, the results of this study are somewhat limited. Additional data collected during wetter years and at higher streamflows would greatly improve the value of the rating curves as tools to estimate long term transport.

\section{References}

Alpers, C.N., Hunerlach, M.P., May, J.T., and Hothem, R.L., 2005, Mercury contamination from historical gold mining in California: U.S. Geological Survey Fact Sheet FS-2005-3014, 6 p. (http://water.usgs.gov/pubs/ $\left.f_{s} / 2005 / 3014 /\right)$.

Alpers, C.N., Hunerlach, M.P., Marvin-DiPasquale, M., Snyder, N.P., and Krabbenhoft, D.P., 2004, Mercury and methylmercury in the upper Yuba River watershed: Fluvial transport and reservoir sedimentation Third Biennial CALFED Bay-Delta Program, Sacramento, Calif., October 4-6, 2004, Science Conference Abstracts, p. 4.

Andrews, E.D., 1983, Entrainment of gravel from naturally sorted riverbed material: Geological Society of America Bulletin, v. 94, p. 1225-1231.

Asselman, N.E.M., 2000, Fitting and interpretation of sediment rating curves: Journal of Hydrology, v. 234, p. $228-248$.

Averill, C.V., 1976, Placer mining for gold in California: California Journal of Mines and Geology, Bulletin 135, p. 93-270.

Bateman, P., and Wahrhaftig, C., 1966, Geology of the Sierra Nevada, in Bailey, E.H., ed., Geology of Northern California, California Division of Mines and Geology, Bulletin 190, p. 105-214.

Bowie, A.J. Jr., 1905, Practical Treatise on Hydraulic Mining: D. Van Nostrand Company, New York, 313 p.

Brown, C.B., and Thorpe, E.M, 1947, Reservoir sedimentation in the Sacramento-San Joaquin drainage basins, California, U.S. Department of Agriculture, Soil Conservation Service Special Report No. 10, 69 p.

Buchanan, P.A., and Ganju, N.K., 2003, Summary of suspended-sediment concentration data, San Francisco Bay, California, water year 2001: U.S. Geological Open-File Report 2003-312, $54 \mathrm{p}$. (http://water.usgs.gov/pubs/of/2003/ofr03312/index/ ofr03312.pdf)

Buchanan, P.A., and Ganju, N.K., 2004, Summary of suspended-sediment concentration data, San Francisco Bay, California, water year 2002: U.S. Geological Open-File Report 2004-1219, 45 p.
(http://water.usgs.gov/pubs/of/2004/1219/CA_3171.pdf)

Buchanan, P.A., and Ruhl, C.A., 2000, Summary of suspended-sediment concentration data, San Francisco Bay, California, water year 1998: U.S. Geological Open-File Report 2000-88, $46 \mathrm{p}$.

(http://onlinepubs.er.usgs.gov/djvu/OFR/2000/ofr_OO_ 88.djvu)

Buchanan, P.A., and Ruhl, C.A., 2001, Summary of suspended-sediment concentration data, San Francisco Bay, California, water year 1999: U.S. Geological Open-File Report 2001-100, 40 p. (http://water.usgs.gov/pubs/of/ ofr01-100)

Buchanan, P.A. and Ruhl, C.A., 2002, Summary of suspended-sediment concentration data, San Francisco Bay, California, water year 2000: U.S. Geological Open-File Report 2002-146, 42 p. (http://water.usgs.gov/pubs/of/ ofr02146/ofr02146.pdf)

California Data Exchange Center, Precipitation/snow information: accessed November 8, 2004 at (http://cdec.water.ca.gov/snow_rain.html)

California Department of Water Resources, 1966, Surface water hydrology of Yuba-Bear Rivers Hydrographic Unit: Sacramento, Calif., Office Report, variously paged, 5 plates.

Childs, J.R., Snyder, N.P., and Hampton, M.A., 2003, Bathymetric and geophysical surveys of Englebright Lake, Yuba-Nevada Counties, California: U. S. Geological Survey Open-File Report 2003-383. (http:// geopubs.wr.usgs.gov/open-file/of03-383/)

Christensen, M.N., 1966, Late Cenozoic crustal movements in the Sierra Nevada of California: Geological Society of America Bulletin, v. 77, p. 162-181.

Church, M., McLean, D.G., Walcott, J.F., 1987, River bed gravels: Sampling and analysis, in Sediment transport in gravel-bed rivers, Thorne, C.R., Bathhurst, J.C., and Hey, R.D. (eds.): John Wiley and Sons, New York, p. 43-88.

Conner, C.S., and De Visser, A.M., 1992, A laboratory investigation of particle size effects on an optical backscatterance sensor: Marine Geology, v. 108, no. 2, p. 151-159.

Curtis, J.A., 1999, A sediment budget of hydraulic gold-mining sediment, Steephollow Creek basin, California, 1853-1997: Arcata, Calif., Humboldt State University, M.A. thesis, $94 \mathrm{p}$

Curtis, J.A., Flint, L.E, and Alpers, C.N., 2004, Sediment transport in the upper Yuba River Watershed, 200103: Third Biennial CALFED Bay-Delta Program, Sacramento, Calif., October 4-6, 2004, Science Conference Abstracts, p. 48.

Curtis, J.A., Flint, L.E., Alpers, C.N., and Yarnell, S.M., 2005, Conceptual model of sediment processes in the upper Yuba River watershed, Sierra Nevada, CA: Geomorphology, v. 68, p. 149-166. doi:10.1016/ j.geomorph.2004.11.019 
Dendy, F.E., and Champion, W.A., 1978, Sediment deposition in U.S. reservoirs: summary of data reported through 1975: U.S. Department of Agriculture Miscellaneous Publication, 1362.

Downing, J.P., Sternberg, R.W., and Lister, C.R.B., 1981, New instrumentation for the investigation of sediment suspension processes in the shallow marine environment: Marine Geology, v. 42, p. 19-34.

Edwards, T.K., and Glysson, G.D., 1999, Field methods for measurement of fluvial sediment: U.S. Geological Survey Techniques of Water-Resources Investigations, book 3, chapter $\mathrm{C} 2,89 \mathrm{p}$. (http://pubs.usgs.gov/twri/twri3-c2/)

Ferguson, R.I., and Paola, C., 1997, Bias and precision of percentiles of bulk grain size distributions: Earth Surface Processes and Landforms, v. 22, no. 11, p. 1061-1078.

Flint, L.E., Guay, J.R., Flint, A.L., Curtis, J.A., and Alpers, C.N., 2004, Spatially distributed model of flow and sediment transport in the upper Yuba River Watershed: Third Biennial CALFED Bay-Delta Program, Sacramento, Calif., October 4-6, 2004, Science Conference Abstracts, p. 78.

Friebel, M.F., Webster, M.D., Rockwell, G.L, and Smithson, J.R., 2003, Water resources data-California, water year 2003, Volume 4. Northern Central Valley Basins and the Great Basin from Honey Lake Basin to Oregon state line: Water-Data Report CA-03-4, p. 520.

(http://pubs.water.usgs.gov/wdr-ca-03-4/)

Gilbert, G.K., 1917, Hydraulic-mining debris in the Sierra Nevada: U.S. Geological Survey Professional Paper 105, $154 \mathrm{p}$.

Glysson, G.D., 1987, Sediment-Transport Curves: U.S. Geological Survey Open-File Report 87-218, 47 p.

Guy, H.P., 1969, Laboratory theory and methods for sediment analysis: U.S. Geological Survey Techniques of WaterResources Investigations, book 5, chapter C1, 58 p. (http://pubs.usgs.gov/twri/twri5c1/)

Hall, W.H., 1880, Mining Debris in the Sacramento River: Report of the State Engineer to Legislature, House Ex Doc 69, 46th Congress, 2nd session, $128 \mathrm{p}$.

Helsel, D.R., and Hirsch, R.M., 1992, Statistical methods in water resources: U.S. Geological Survey, Techniques of Water-Resources Investigations, book 4, chapter A3, 522 p. (http://water.usgs.gov/pubs/twri/twri4a3/)

Horowitz, A.J., 2002, The use of rating (transport) curves to predict suspended sediment concentration: a matter of temporal resolution, Turbidity and Other Sediment Surrogates Workshop, April 30-May 2, 2002, Reno, NV. http://water.usgs.gov/pubs/circ/2003/circ1250/

James, L.A., 1993, Sustained reworking of hydraulic mining sediment in California: G.K. Gilbert's sediment wave model reconsidered: Zeitschrift fur Geomorphologie, Suppl.- Bd., v. 88, p. 49-66.
James, L.A., 2005, Sediment from hydraulic mining detained by Englebright and small dams in the Yuba Basin: Geomorphology, v. 71, no. 1-2, p. 202-226.

James, L.A., Harbor, J., Fabel, D., Dahms, D., and Elmore, D., 2002, Late Pleistocene glaciations in the Northwestern Sierra Nevada, California: Quaternary Research, v. 57, p. 409-419.

Kattelman, R., 1996, Hydrology and Water Resources, Sierra Nevada Ecosystem Project: Final Report to Congress. Center for Water and Wildland Resources: University of California, Davis, Calif., v. 2, chapter 30, p. 855-920. (http://ceres.ca.gov/snep/)

Levesque, V.A., and Schoellhamer, D.H., 1995, Summary of sediment resuspension monitoring activities, Old Tampa Bay and Hillsborough Bay, Florida, 1988-91: U. S. Geological Survey Water-Resources Investigations Report 94-4081, $31 \mathrm{p}$.

Lindgren, W., 1911, Tertiary gravels of the Sierra Nevada of California: U.S. Geological Survey Professional Paper 73, $226 \mathrm{p}$.

May, P.R., 1970, Origins of Hydraulic Mining: Oakland, Calif., The Holmes Book Company, 88 p.

Meyer-Peter, E., and Müller, R., 1948, Formulas for bed-load transport: in Proceedings, 2nd Meeting, International Association for Hydraulic Research, Stockholm, Sweden, p. 39-64.

Milhous, R.T., 1973, Sediment transport in a gravel-bottom stream: Corvallis, Ore., Oregon State University, Ph.D. thesis, $232 \mathrm{p}$.

Parker, G., 1990, Surface-based bedload transport relation for gravel rivers: Journal of Hydraulic Research, v. 28, no. 4, p. 417-436.

Parker, G., Klingeman, P.C., and McLean, D.G., 1982, Bedload and size distribution in paved gravel-bed streams: Journal of the Hydraulics Division, Proceedings of the American Society of Civil Engineers, v. 108, no. HY4, p. 544-571.

Porterfield, G., Busch, R.D., and Waananen, A.O., 1978, Sediment transport in the Feather River, Lake Oroville to Yuba City, California: U.S. Geological Survey WaterResources Investigations 78-20, $73 \mathrm{p}$.

Rockwell, G.L, Smithson, J.R., Friebel, M.F., and Webster, M.D., 2001, Water resources data-California, water year 2001, Volume 4. Northern Central Valley Basins and the Great Basin from Honey Lake Basin to Oregon state line: Water-Data Report CA-01-4, p. 458. (http://water.usgs.gov/pubs/wdr/WDR-CA-01-4/)

Saucedo, G.J., and Wagner, D.L., 1992, Geologic map of the Chico quadrangle scale 1:250,000: California Department of Mines and Geology RGM007A.

Schoellhamer, D.H., and Wright, S.A., 2003, Continuous measurement of suspended-sediment discharge in rivers by use of optical backscatterance sensors: International Association of Hydrological Sciences (IAHS) Publication 283, p. $28-36$ 
Siegel, A.R., 1982, Robust regression using repeated medians: Biometrika, v. 69, p. 242-244.

Slotton, D.G., Ayers, S.M., Alpers, C.N., and Goldman, C.R., 2004, Bioaccumulation of gold-rush mercury in reaches of the Yuba River watershed proposed for anadromous fish reintroduction: Third Biennial CALFED Bay-Delta Program, Sacramento, Calif., October 4-6, 2004, Science Conference Abstracts, p. 388.

Smithson, J.R., Friebel, M.F., Webster, M.D., and Rockwell, G.L., 2002, Water resources data-California, water year 2002, Volume 4. Northern Central Valley Basins and the Great Basin from Honey Lake Basin to Oregon state line: Water-Data Report CA-02-4, p. 470. (http://water.usgs.gov/pubs/wdr/WDR-CA-02-4/)

Snyder, N.P., Allen, J.R., Dare, C. Hampton, M.A., Schneider, G., Wooley, R.J., Alpers, C.N., and Marvin-DiPasquale, M.C., 2004a, Sediment grain-size and loss-on-ignition analyses from 2002 Englebright Lake coring and sampling campaigns: U.S. Geological Survey Open-File Report 2004-1080 (http://pubs.usgs.gov/of/2004/1080/)

Snyder, N.P., Alpers, C.N., Flint, L.E., Curtis, J.A., Hampton, M.A., Haskell, B.J., and Nielson, D.L., 2004b, Report on the May-June 2002 Englebright Lake deep coring campaign: U.S. Geological Survey Open-File Report 20041061 (http://pubs.usgs.gov/of/2004/1061/)

Snyder, N.P., Rubin, D.M., Alpers, C.N., Childs, J.R., Curtis, J.A., Flint, L.E., Wright, S.A., 2004c, Estimating rates and physical properties of sediment behind a dam: Englebright Lake, Yuba River, northern California: Water Resources Research v. 40, p. W11301, doi:10.1029/ 2004WR003279.

Sutherland, T.F., Lane, P.M., Amos, C.L., and Downing, J., 2000, The calibration of optical backscatter sensors for suspended sediment of varying darkness levels: Marine Geology, v. 162, p. 587-597.

Turner, F.C., 1891, Reports of Mr. F. C. Turner, Asst. Engineer, of reconnaissance of Feather, Yuba, Bear, and American rivers above the Foot Hills, and of deposits of mining gravel subject to hydraulic process in their basins, Appendix VV, House Doc 1, Part 2, 52nd Congress, 1st session, 3041-3087.
Wakabayashi, J., and Sawyer, T.L., 2001, Stream incision, tectonics, uplift, and evolution of topography of the Sierra Nevada, California: Journal of Geology, v. 109, no. 5, p. 539-562.

Walling, D.E., 1977, Limitations of the rating curve technique for estimating suspended sediment loads, with particular reference to British rivers: Erosion and soils matter transport in inland waters: International Association of Hydrological Sciences (IAHS) Publication 122, p. 34-48.

Western Regional Climate Center (WRCC), 2003, Western U.S. Historical Summaries by State, accessed November 8,2004 at http://www.wrcc.dri.edu/htmlfiles/ca/ca.ppt.ext.html.

Whitney, J.D., 1880, The auriferous gravels of the Sierra Nevada: Memoir of the Museum of Comparative Zoology, v. 6, 569 p.

Wilcock, P.R., and Crowe, J.C., 2003, Surface-based transport model for mixed-size sediment: Journal of Hydraulic Engineering, v. 19, no. 2, p. 120-128.

Wilcock, P.R., Kentworthy, S.T., and Crowe, J.C., 2001, Experimental study of the transport of mixed sand and gravel: Water Resources Research, v. 24, no. 7, p. 1137-1151.

Wildman, N., 1981, Episodic removal of hydraulic mining-debris, Yuba and Bear River basins, California: Fort Collins, Colo., Colorado State University, M.A. thesis, 107 p.

Wolman, M.G., 1954, A method of sampling coarse bed material: American Geophysical Union, Transactions, v. 35, p. 951-956.

Yeend, W.E., 1974, Gold-bearing gravel of the ancestral Yuba River, Sierra Nevada, California: U.S. Geological Survey Professional Paper 772, 44 p.

Yuan, G., 1979, The geomorphic development of an hydraulic mining site in Nevada County, California: Stanford, California, Stanford University, M.A. thesis, 56 p.

Yuba County Water Agency (YCWA), 1989, Cleanup and abatement of sediments sluiced from Our House Reservoir: Technical Report, Continued Streambed Monitoring Program 1988/1989, 69 p. 


\section{Appendix 1.}

Table A1a. Suspended-sediment concentration samples and associated instantaneous streamflow for the Middle Yuba River near North San Juan (MYG) collected during water years 2001, 2002, and 2003.

[USGS Marina sediment laboratory uses $0.5 \mathrm{mg} / \mathrm{L}$ (milligram per liter) as the detection limit for reporting suspended-sediment concentration (SSC); therefore, samples with SSC of less than 0.5 $\mathrm{mg} / \mathrm{L}$ are reported as $0.25 \mathrm{mg} / \mathrm{L}$ (Helsel and Hirsch, 1992). $\mathrm{ft}^{3} / \mathrm{s}$, cubic feet per second]

\begin{tabular}{|c|c|c|c|c|c|}
\hline $\begin{array}{c}\text { Map } \\
\text { identifier }\end{array}$ & $\begin{array}{l}\text { Station } \\
\text { identifier }\end{array}$ & Date & Time & $\begin{array}{c}\text { Instan- } \\
\text { taneous } \\
\text { stream- } \\
\text { flow } \\
\left(\mathrm{ft}^{3} / \mathrm{s}\right)\end{array}$ & $\begin{array}{c}\text { Sus- } \\
\text { pended- } \\
\text { sediment } \\
\text { concen- } \\
\text { tration } \\
\text { (mg/L) }\end{array}$ \\
\hline \multirow[t]{41}{*}{ MYG } & 11410000 & $11 / 07 / 00$ & 1020 & 49 & 0.25 \\
\hline & 11410000 & $11 / 08 / 00$ & 1115 & 49 & 0.25 \\
\hline & 11410000 & $11 / 13 / 00$ & 1010 & 51 & 0.25 \\
\hline & 11410000 & $11 / 14 / 00$ & 0955 & 53 & 2 \\
\hline & 11410000 & $11 / 15 / 00$ & 0935 & 52 & 1 \\
\hline & 11410000 & $11 / 16 / 00$ & 0940 & 51 & 0.25 \\
\hline & 11410000 & $11 / 17 / 00$ & 1330 & 49 & 1 \\
\hline & 11410000 & $11 / 20 / 00$ & 1205 & 49 & 1 \\
\hline & 11410000 & $11 / 21 / 00$ & 1150 & 49 & 1 \\
\hline & 11410000 & $11 / 22 / 00$ & 1030 & 49 & 1 \\
\hline & 11410000 & $11 / 24 / 00$ & 1100 & 49 & 1 \\
\hline & 11410000 & $11 / 27 / 00$ & 1100 & 49 & 2 \\
\hline & 11410000 & $11 / 29 / 00$ & 1130 & 68 & 2 \\
\hline & 11410000 & $11 / 29 / 00$ & 1130 & 68 & 2 \\
\hline & 11410000 & $11 / 30 / 00$ & 1100 & 53 & 2 \\
\hline & 11410000 & $12 / 01 / 00$ & 1125 & 51 & 1 \\
\hline & 11410000 & $12 / 04 / 00$ & 1100 & 49 & 3 \\
\hline & 11410000 & $12 / 05 / 00$ & 1120 & 49 & 1 \\
\hline & 11410000 & $12 / 06 / 00$ & 1115 & 49 & 2 \\
\hline & 11410000 & $12 / 07 / 00$ & 1100 & 48 & 2 \\
\hline & 11410000 & $12 / 11 / 00$ & 1100 & 51 & 3 \\
\hline & 11410000 & $12 / 12 / 00$ & 1100 & 66 & 2 \\
\hline & 11410000 & $12 / 13 / 00$ & 1115 & 53 & 3 \\
\hline & 11410000 & $12 / 14 / 00$ & 1100 & 86 & 30 \\
\hline & 11410000 & $12 / 15 / 00$ & 1045 & 86 & 15 \\
\hline & 11410000 & $12 / 18 / 00$ & 1100 & 56 & 6 \\
\hline & 11410000 & $12 / 19 / 00$ & 1050 & 55 & 1 \\
\hline & 11410000 & $12 / 20 / 00$ & 1045 & 53 & 4 \\
\hline & 11410000 & $12 / 21 / 00$ & 1045 & 53 & 1 \\
\hline & 11410000 & $12 / 22 / 00$ & 1050 & 55 & 6 \\
\hline & 11410000 & $12 / 26 / 00$ & 1100 & 51 & 5 \\
\hline & 11410000 & $12 / 27 / 00$ & 1055 & 51 & 2 \\
\hline & 11410000 & $12 / 27 / 00$ & 1055 & 51 & 1 \\
\hline & 11410000 & $12 / 28 / 00$ & 1030 & 51 & 1 \\
\hline & 11410000 & $12 / 29 / 00$ & 1045 & 51 & 1 \\
\hline & 11410000 & 01/03/01 & 1050 & 49 & 1 \\
\hline & 11410000 & 01/03/01 & 1050 & 49 & 2 \\
\hline & 11410000 & 01/04/01 & 1100 & 51 & 1 \\
\hline & 11410000 & 01/05/01 & 1300 & 49 & 2 \\
\hline & 11410000 & 01/08/01 & 1115 & 58 & 2 \\
\hline & 11410000 & 01/09/01 & 1100 & 52 & 1 \\
\hline
\end{tabular}

Table A1a. Suspended-sediment concentration samples and associated instantaneous streamflow for the Middle Yuba River near North San Juan (MYG) collected during water years 2001, 2002, and 2003.

[USGS Marina sediment laboratory uses $0.5 \mathrm{mg} / \mathrm{L}$ (milligram per liter) as the detection limit for reporting suspended-sediment concentration (SSC); therefore, samples with SSC of less than 0.5 $\mathrm{mg} / \mathrm{L}$ are reported as $0.25 \mathrm{mg} / \mathrm{L}$ (Helsel and Hirsch, 1992). $\mathrm{ft}^{3} / \mathrm{s}$, cubic feet per second]

\begin{tabular}{|c|c|c|c|c|c|}
\hline $\begin{array}{c}\text { Map } \\
\text { identifier }\end{array}$ & $\begin{array}{l}\text { Station } \\
\text { identifier }\end{array}$ & Date & Time & $\begin{array}{l}\text { Instan- } \\
\text { taneous } \\
\text { stream- } \\
\text { flow } \\
\left(\mathrm{ft}^{3} / \mathrm{s}\right)\end{array}$ & $\begin{array}{c}\text { Sus- } \\
\text { pended- } \\
\text { sediment } \\
\text { concen- } \\
\text { tration } \\
(\mathrm{mg} / \mathrm{L})\end{array}$ \\
\hline \multirow[t]{45}{*}{ MYG } & 11410000 & $01 / 10 / 01$ & 1115 & 55 & 1 \\
\hline & 11410000 & $01 / 12 / 01$ & 1115 & 66 & 4 \\
\hline & 11410000 & 01/17/01 & 1100 & 53 & 0.25 \\
\hline & 11410000 & 01/18/01 & 1035 & 52 & 1 \\
\hline & 11410000 & 01/19/01 & 1030 & 52 & 1 \\
\hline & 11410000 & $01 / 22 / 01$ & 1210 & 51 & 1 \\
\hline & 11410000 & $01 / 23 / 01$ & 1030 & 52 & 2 \\
\hline & 11410000 & $01 / 24 / 01$ & 1045 & 68 & 11 \\
\hline & 11410000 & 01/24/01 & 1045 & 68 & 9 \\
\hline & 11410000 & $01 / 25 / 01$ & 1040 & 61 & 5 \\
\hline & 11410000 & $01 / 26 / 01$ & 1030 & 65 & 5 \\
\hline & 11410000 & $01 / 29 / 01$ & 1028 & 65 & 2 \\
\hline & 11410000 & 01/30/01 & 1030 & 58 & 5 \\
\hline & 11410000 & $01 / 31 / 01$ & 1035 & 55 & 1 \\
\hline & 11410000 & $01 / 31 / 01$ & 1035 & 55 & 2 \\
\hline & 11410000 & $02 / 02 / 01$ & 1020 & 53 & 1 \\
\hline & 11410000 & $02 / 05 / 01$ & 1035 & 55 & 3 \\
\hline & 11410000 & 02/06/01 & 1055 & 53 & 1 \\
\hline & 11410000 & 02/07/01 & 1020 & 53 & 1 \\
\hline & 11410000 & 02/07/01 & 1020 & 53 & 1 \\
\hline & 11410000 & 02/08/01 & 1025 & 52 & 0.25 \\
\hline & 11410000 & 02/09/01 & 1020 & 52 & 1 \\
\hline & 11410000 & 02/10/01 & 1240 & 68 & 1 \\
\hline & 11410000 & 02/11/01 & 1105 & 84 & 2 \\
\hline & 11410000 & 02/13/01 & 1030 & 63 & 2 \\
\hline & 11410000 & 02/15/01 & 1020 & 60 & 1 \\
\hline & 11410000 & 02/15/01 & 1020 & 60 & 1 \\
\hline & 11410000 & 02/16/01 & 1025 & 58 & 1 \\
\hline & 11410000 & 02/20/01 & 1045 & 105 & 18 \\
\hline & 11410000 & 02/22/01 & 1025 & 153 & 11 \\
\hline & 11410000 & 02/23/01 & 1030 & 113 & 3 \\
\hline & 11410000 & $02 / 26 / 01$ & 1040 & 84 & 2 \\
\hline & 11410000 & 02/27/01 & 1035 & 74 & 1 \\
\hline & 11410000 & 02/27/01 & 1300 & 74 & 5 \\
\hline & 11410000 & 02/28/01 & 1040 & 70 & 0.25 \\
\hline & 11410000 & 03/02/01 & 1040 & 82 & 3 \\
\hline & 11410000 & 03/05/01 & 1045 & 140 & 7 \\
\hline & 11410000 & 03/06/01 & 1100 & 105 & 3 \\
\hline & 11410000 & 03/07/01 & 1105 & 88 & 2 \\
\hline & 11410000 & 03/08/01 & 1105 & 84 & 1 \\
\hline & 11410000 & 03/09/01 & 1045 & 84 & 2 \\
\hline & 11410000 & 03/09/01 & 1045 & 84 & 2 \\
\hline & 11410000 & 03/12/01 & 1040 & 70 & 2 \\
\hline & 11410000 & 03/13/01 & 1045 & 68 & 2 \\
\hline & 11410000 & 03/13/01 & 1415 & 68 & 0.25 \\
\hline
\end{tabular}


Table A1a. Suspended-sediment concentration samples and associated instantaneous streamflow for the Middle Yuba River near North San Juan (MYG) collected during water years 2001, 2002, and 2003.

[USGS Marina sediment laboratory uses $0.5 \mathrm{mg} / \mathrm{L}$ (milligram per liter) as the detection limit for reporting suspended-sediment concentration (SSC); therefore, samples with SSC of less than 0.5 $\mathrm{mg} / \mathrm{L}$ are reported as $0.25 \mathrm{mg} / \mathrm{L}$ (Helsel and Hirsch, 1992). $\mathrm{ft}^{3} / \mathrm{s}$, cubic feet per second]

\begin{tabular}{|c|c|c|c|c|c|}
\hline $\begin{array}{c}\text { Map } \\
\text { identifier }\end{array}$ & $\begin{array}{l}\text { Station } \\
\text { identifier }\end{array}$ & Date & Time & $\begin{array}{c}\text { Instan- } \\
\text { taneous } \\
\text { stream- } \\
\text { flow } \\
\left(\mathrm{ft}^{3} / \mathrm{s}\right)\end{array}$ & $\begin{array}{c}\text { Sus- } \\
\text { pended- } \\
\text { sediment } \\
\text { concen- } \\
\text { tration } \\
\text { (mg/L) }\end{array}$ \\
\hline \multirow[t]{45}{*}{ MYG } & 11410000 & $03 / 14 / 01$ & 1050 & 66 & 2 \\
\hline & 11410000 & 03/14/01 & 1050 & 66 & 3 \\
\hline & 11410000 & 03/15/01 & 1045 & 66 & 2 \\
\hline & 11410000 & 03/16/01 & 1045 & 65 & 1 \\
\hline & 11410000 & 03/19/01 & 1050 & 65 & 2 \\
\hline & 11410000 & 03/20/01 & 1045 & 66 & 3 \\
\hline & 11410000 & $03 / 22 / 01$ & 1015 & 66 & 4 \\
\hline & 11410000 & 03/23/01 & 1205 & 66 & 4 \\
\hline & 11410000 & $03 / 26 / 01$ & 1040 & 74 & 8 \\
\hline & 11410000 & 03/27/01 & 1055 & 66 & 4 \\
\hline & 11410000 & 03/28/01 & 1055 & 66 & 4 \\
\hline & 11410000 & $03 / 29 / 01$ & 1045 & 66 & 2 \\
\hline & 11410000 & 03/30/01 & 1055 & 65 & 4 \\
\hline & 11410000 & 03/30/01 & 1055 & 65 & 2 \\
\hline & 11410000 & 04/02/01 & 1040 & 63 & 1 \\
\hline & 11410000 & 04/04/01 & 1045 & 60 & 3 \\
\hline & 11410000 & 04/04/01 & 1050 & 60 & 2 \\
\hline & 11410000 & 04/05/01 & 1100 & 60 & 1 \\
\hline & 11410000 & 04/06/01 & 1055 & 60 & 1 \\
\hline & 11410000 & 04/06/01 & 1055 & 60 & 1 \\
\hline & 11410000 & 04/09/01 & 1050 & 61 & 1 \\
\hline & 11410000 & 04/09/01 & 1050 & 61 & 1 \\
\hline & 11410000 & 04/10/01 & 1100 & 61 & 1 \\
\hline & 11410000 & 04/11/01 & 1055 & 60 & 1 \\
\hline & 11410000 & 04/13/01 & 1040 & 60 & 2 \\
\hline & 11410000 & 04/16/01 & 1045 & 78 & 3 \\
\hline & 11410000 & 04/16/01 & 1050 & 78 & 3 \\
\hline & 11410000 & 04/18/01 & 1100 & 80 & 1 \\
\hline & 11410000 & 04/20/01 & 1105 & 93 & 2 \\
\hline & 11410000 & $04 / 23 / 01$ & 1050 & 82 & 1 \\
\hline & 11410000 & $04 / 23 / 01$ & 1100 & 84 & 1 \\
\hline & 11410000 & $04 / 23 / 01$ & 1100 & 84 & 1 \\
\hline & 11410000 & $04 / 25 / 01$ & 1050 & 84 & 2 \\
\hline & 11410000 & 04/26/01 & 1055 & 84 & 1 \\
\hline & 11410000 & $04 / 26 / 01$ & 1055 & 84 & 2 \\
\hline & 11410000 & 04/30/01 & 1045 & 78 & 3 \\
\hline & 11410000 & 05/01/01 & 1050 & 78 & 4 \\
\hline & 11410000 & 05/03/01 & 1045 & 78 & 4 \\
\hline & 11410000 & 05/04/01 & 1040 & 76 & 3 \\
\hline & 11410000 & 05/07/01 & 1045 & 76 & 4 \\
\hline & 11410000 & 05/08/01 & 1045 & 76 & 5 \\
\hline & 11410000 & 05/09/01 & 1030 & 78 & 4 \\
\hline & 11410000 & 05/10/01 & 1030 & 78 & 3 \\
\hline & 11410000 & 05/11/01 & 1030 & 76 & 3 \\
\hline & 11410000 & 05/14/01 & 1030 & 74 & 2 \\
\hline
\end{tabular}

Table A1a. Suspended-sediment concentration samples and associated instantaneous streamflow for the Middle Yuba River near North San Juan (MYG) collected during water years 2001, 2002, and 2003.

[USGS Marina sediment laboratory uses $0.5 \mathrm{mg} / \mathrm{L}$ (milligram per liter) as the detection limit for reporting suspended-sediment concentration (SSC); therefore, samples with SSC of less than 0.5 $\mathrm{mg} / \mathrm{L}$ are reported as $0.25 \mathrm{mg} / \mathrm{L}$ (Helsel and Hirsch, 1992). $\mathrm{ft}^{3} / \mathrm{s}$, cubic feet per second]

\begin{tabular}{|c|c|c|c|c|c|}
\hline $\begin{array}{c}\text { Map } \\
\text { identifier }\end{array}$ & $\begin{array}{c}\text { Station } \\
\text { identifier }\end{array}$ & Date & Time & $\begin{array}{l}\text { Instan- } \\
\text { taneous } \\
\text { stream- } \\
\text { flow } \\
\left(\mathrm{ft}^{3} / \mathrm{s}\right)\end{array}$ & $\begin{array}{c}\text { Sus- } \\
\text { pended- } \\
\text { sediment } \\
\text { concen- } \\
\text { tration } \\
\text { (mg/L) }\end{array}$ \\
\hline \multirow[t]{45}{*}{ MYG } & 11410000 & $05 / 15 / 01$ & 1050 & 74 & 3 \\
\hline & 11410000 & $05 / 17 / 01$ & 1045 & 72 & 2 \\
\hline & 11410000 & 05/18/01 & 1030 & 70 & 2 \\
\hline & 11410000 & $05 / 21 / 01$ & 1025 & 66 & 2 \\
\hline & 11410000 & $05 / 22 / 01$ & 1020 & 68 & 4 \\
\hline & 11410000 & $05 / 23 / 01$ & 1045 & 68 & 2 \\
\hline & 11410000 & $05 / 24 / 01$ & 1050 & 68 & 4 \\
\hline & 11410000 & $05 / 25 / 01$ & 1030 & 68 & 2 \\
\hline & 11410000 & $05 / 29 / 01$ & 1040 & 68 & 3 \\
\hline & 11410000 & 05/30/01 & 1030 & 68 & 3 \\
\hline & 11410000 & $05 / 31 / 01$ & 1040 & 66 & 2 \\
\hline & 11410000 & $06 / 01 / 01$ & 1035 & 66 & 3 \\
\hline & 11410000 & $06 / 04 / 01$ & 1030 & 66 & 3 \\
\hline & 11410000 & $06 / 05 / 01$ & 1045 & 66 & 4 \\
\hline & 11410000 & 06/06/01 & 1040 & 66 & 3 \\
\hline & 11410000 & $06 / 07 / 01$ & 1040 & 66 & 2 \\
\hline & 11410000 & 06/08/01 & 1035 & 66 & 1 \\
\hline & 11410000 & $06 / 11 / 01$ & 1045 & 78 & 2 \\
\hline & 11410000 & $06 / 12 / 01$ & 1145 & 76 & 3 \\
\hline & 11410000 & 06/13/01 & 1050 & 76 & 1 \\
\hline & 11410000 & $06 / 14 / 01$ & 1050 & 74 & 2 \\
\hline & 11410000 & $06 / 18 / 01$ & 1055 & 60 & 3 \\
\hline & 11410000 & $06 / 19 / 01$ & 1050 & 58 & 2 \\
\hline & 11410000 & $06 / 20 / 01$ & 1045 & 58 & 2 \\
\hline & 11410000 & $06 / 21 / 01$ & 1040 & 47 & 1 \\
\hline & 11410000 & $06 / 22 / 01$ & 1010 & 47 & 1 \\
\hline & 11410000 & $06 / 25 / 01$ & 1045 & 44 & 1 \\
\hline & 11410000 & $06 / 26 / 01$ & 1030 & 48 & 3 \\
\hline & 11410000 & $06 / 27 / 01$ & 1035 & 48 & 2 \\
\hline & 11410000 & $06 / 28 / 01$ & 1030 & 49 & 1 \\
\hline & 11410000 & $06 / 29 / 01$ & 1045 & 49 & 1 \\
\hline & 11410000 & $07 / 02 / 01$ & 1030 & 45 & 2 \\
\hline & 11410000 & $07 / 03 / 01$ & 1030 & 44 & 3 \\
\hline & 11410000 & 07/05/01 & 0930 & 43 & 1 \\
\hline & 11410000 & $07 / 06 / 01$ & 1045 & 42 & 1 \\
\hline & 11410000 & $07 / 09 / 01$ & 1030 & 39 & 1 \\
\hline & 11410000 & $07 / 10 / 01$ & 1055 & 39 & 1 \\
\hline & 11410000 & $07 / 11 / 01$ & 1045 & 39 & 2 \\
\hline & 11410000 & $07 / 12 / 01$ & 1035 & 38 & 2 \\
\hline & 11410000 & $07 / 13 / 01$ & 1045 & 38 & 1 \\
\hline & 11410000 & $07 / 16 / 01$ & 1050 & 36 & 1 \\
\hline & 11410000 & $07 / 17 / 01$ & 1055 & 36 & 3 \\
\hline & 11410000 & $07 / 18 / 01$ & 1040 & 37 & 2 \\
\hline & 11410000 & 07/19/01 & 1050 & 38 & 3 \\
\hline & 11410000 & $07 / 20 / 01$ & 1030 & 37 & 1 \\
\hline
\end{tabular}


Table A1a. Suspended-sediment concentration samples and associated instantaneous streamflow for the Middle Yuba River near North San Juan (MYG) collected during water years 2001, 2002, and 2003.

[USGS Marina sediment laboratory uses $0.5 \mathrm{mg} / \mathrm{L}$ (milligram per liter) as the detection limit for reporting suspended-sediment concentration (SSC); therefore, samples with SSC of less than 0.5 $\mathrm{mg} / \mathrm{L}$ are reported as $0.25 \mathrm{mg} / \mathrm{L}$ (Helsel and Hirsch, 1992). $\mathrm{ft}^{3} / \mathrm{s}$, cubic feet per second]

\begin{tabular}{|c|c|c|c|c|c|}
\hline $\begin{array}{c}\text { Map } \\
\text { identifier }\end{array}$ & $\begin{array}{l}\text { Station } \\
\text { identifier }\end{array}$ & Date & Time & $\begin{array}{l}\text { Instan- } \\
\text { taneous } \\
\text { stream- } \\
\text { flow } \\
\left(\mathrm{ft}^{3} / \mathrm{s}\right)\end{array}$ & $\begin{array}{c}\text { Sus- } \\
\text { pended- } \\
\text { sediment } \\
\text { concen- } \\
\text { tration } \\
\text { (mg/L) }\end{array}$ \\
\hline \multirow[t]{43}{*}{ MYG } & 11410000 & $07 / 23 / 01$ & 1145 & 37 & 1 \\
\hline & 11410000 & $07 / 24 / 01$ & 1115 & 37 & 1 \\
\hline & 11410000 & $07 / 25 / 01$ & 1030 & 36 & 1 \\
\hline & 11410000 & $07 / 26 / 01$ & 1030 & 36 & 0.25 \\
\hline & 11410000 & $07 / 27 / 01$ & 1100 & 35 & 1 \\
\hline & 11410000 & $07 / 30 / 01$ & 1055 & 33 & 1 \\
\hline & 11410000 & $07 / 31 / 01$ & 1030 & 34 & 2 \\
\hline & 11410000 & 08/01/01 & 1045 & 36 & 2 \\
\hline & 11410000 & $08 / 02 / 01$ & 1030 & 35 & 3 \\
\hline & 11410000 & 08/03/01 & 0905 & 34 & 1 \\
\hline & 11410000 & 08/06/01 & 1100 & 32 & 2 \\
\hline & 11410000 & 08/07/01 & 0950 & 32 & 2 \\
\hline & 11410000 & $08 / 15 / 01$ & 1015 & 30 & 0.25 \\
\hline & 11410000 & $08 / 21 / 01$ & 0955 & 29 & 1 \\
\hline & 11410000 & $09 / 05 / 01$ & 1000 & 28 & 4 \\
\hline & 11410000 & $09 / 11 / 01$ & 0920 & 27 & 2 \\
\hline & 11410000 & $09 / 21 / 01$ & 1055 & 28 & 1 \\
\hline & 11410000 & $09 / 27 / 01$ & 1100 & 28 & 3 \\
\hline & 11410000 & $09 / 30 / 01$ & 1400 & 28 & 0.25 \\
\hline & 11410000 & $10 / 03 / 01$ & 1130 & 30 & 2 \\
\hline & 11410000 & $10 / 10 / 01$ & 1115 & 31 & 1 \\
\hline & 11410000 & $10 / 17 / 01$ & 1045 & 31 & 2 \\
\hline & 11410000 & $10 / 24 / 01$ & 1110 & 31 & 2 \\
\hline & 11410000 & $10 / 30 / 01$ & 1105 & 42 & 3 \\
\hline & 11410000 & $11 / 01 / 01$ & 0850 & 45 & 3 \\
\hline & 11410000 & $11 / 02 / 01$ & 1115 & 42 & 1 \\
\hline & 11410000 & $11 / 07 / 01$ & 1100 & 36 & 0.25 \\
\hline & 11410000 & $11 / 13 / 01$ & 1030 & 65 & 5 \\
\hline & 11410000 & $11 / 14 / 01$ & 1005 & 53 & 2 \\
\hline & 11410000 & $11 / 26 / 01$ & 1040 & 56 & 2 \\
\hline & 11410000 & $11 / 27 / 01$ & 1100 & 49 & 1 \\
\hline & 11410000 & $11 / 28 / 01$ & 1100 & 48 & 1 \\
\hline & 11410000 & $11 / 29 / 01$ & 1025 & 53 & 1 \\
\hline & 11410000 & $11 / 30 / 01$ & 1125 & 58 & 4 \\
\hline & 11410000 & $12 / 03 / 01$ & 1045 & 102 & 18 \\
\hline & 11410000 & $12 / 04 / 01$ & 1115 & 63 & 6 \\
\hline & 11410000 & $12 / 05 / 01$ & 1045 & 78 & 3 \\
\hline & 11410000 & $12 / 06 / 01$ & 1030 & 140 & 7 \\
\hline & 11410000 & $12 / 07 / 01$ & 1045 & 78 & 3 \\
\hline & 11410000 & $12 / 11 / 01$ & 1030 & 52 & 2 \\
\hline & 11410000 & $12 / 12 / 01$ & 1050 & 51 & 1 \\
\hline & 11410000 & $12 / 13 / 01$ & 1030 & 48 & 2 \\
\hline & 11410000 & $12 / 14 / 01$ & 1115 & 110 & 15 \\
\hline
\end{tabular}

Table A1a. Suspended-sediment concentration samples and associated instantaneous streamflow for the Middle Yuba River near North San Juan (MYG) collected during water years 2001, 2002, and 2003.

[USGS Marina sediment laboratory uses $0.5 \mathrm{mg} / \mathrm{L}$ (milligram per liter) as the detection limit for reporting suspended-sediment concentration (SSC); therefore, samples with SSC of less than 0.5 $\mathrm{mg} / \mathrm{L}$ are reported as $0.25 \mathrm{mg} / \mathrm{L}$ (Helsel and Hirsch, 1992). $\mathrm{ft}^{3} / \mathrm{s}$, cubic feet per second]

\begin{tabular}{|c|c|c|c|c|c|}
\hline $\begin{array}{c}\text { Map } \\
\text { identifier }\end{array}$ & $\begin{array}{l}\text { Station } \\
\text { identifier }\end{array}$ & Date & Time & $\begin{array}{c}\text { Instan- } \\
\text { taneous } \\
\text { stream- } \\
\text { flow } \\
\left(\mathrm{ft}^{3} / \mathrm{s}\right)\end{array}$ & $\begin{array}{c}\text { Sus- } \\
\text { pended- } \\
\text { sediment } \\
\text { concen- } \\
\text { tration } \\
\text { (mg/L) }\end{array}$ \\
\hline \multirow[t]{45}{*}{ MYG } & 11410000 & $12 / 15 / 01$ & 1010 & 63 & 4 \\
\hline & 11410000 & $12 / 18 / 01$ & 1035 & 108 & 4 \\
\hline & 11410000 & $12 / 19 / 01$ & 1050 & 70 & 3 \\
\hline & 11410000 & $12 / 20 / 01$ & 1030 & 97 & 3 \\
\hline & 11410000 & $12 / 21 / 01$ & 1005 & 110 & 7 \\
\hline & 11410000 & $12 / 26 / 01$ & 0 & 60 & 3 \\
\hline & 11410000 & $12 / 27 / 01$ & 1105 & 60 & 2 \\
\hline & 11410000 & $12 / 28 / 01$ & 1020 & 58 & 1 \\
\hline & 11410000 & $12 / 29 / 01$ & 0945 & 90 & 3 \\
\hline & 11410000 & $12 / 31 / 01$ & 1530 & 701 & 28 \\
\hline & 11410000 & $01 / 03 / 02$ & 1105 & 423 & 6 \\
\hline & 11410000 & $01 / 04 / 02$ & 1010 & 110 & 6 \\
\hline & 11410000 & 01/08/02 & 1025 & 108 & 0.25 \\
\hline & 11410000 & $01 / 09 / 02$ & 1020 & 95 & 0.25 \\
\hline & 11410000 & $01 / 09 / 02$ & 1020 & 95 & 1 \\
\hline & 11410000 & 01/10/02 & 1105 & 88 & 1 \\
\hline & 11410000 & $01 / 11 / 02$ & 1040 & 82 & 0.25 \\
\hline & 11410000 & $01 / 14 / 02$ & 1030 & 74 & 0.25 \\
\hline & 11410000 & $01 / 14 / 02$ & 1030 & 74 & 0.25 \\
\hline & 11410000 & $01 / 15 / 02$ & 1035 & 70 & 0.25 \\
\hline & 11410000 & $01 / 16 / 02$ & 1055 & 68 & 0.25 \\
\hline & 11410000 & $01 / 17 / 02$ & 1050 & 66 & 1 \\
\hline & 11410000 & $01 / 17 / 02$ & 1050 & 66 & 0.25 \\
\hline & 11410000 & $01 / 18 / 02$ & 1105 & 65 & 0.25 \\
\hline & 11410000 & $01 / 22 / 02$ & 1045 & 66 & 0.25 \\
\hline & 11410000 & $01 / 23 / 02$ & 1025 & 65 & 1 \\
\hline & 11410000 & $01 / 23 / 02$ & 1025 & 65 & 3 \\
\hline & 11410000 & $01 / 24 / 02$ & 1035 & 63 & 0.25 \\
\hline & 11410000 & $01 / 25 / 02$ & 1030 & 63 & 1 \\
\hline & 11410000 & $01 / 28 / 02$ & 1025 & 80 & 2 \\
\hline & 11410000 & $01 / 28 / 02$ & 1025 & 80 & 1 \\
\hline & 11410000 & $01 / 29 / 02$ & 1100 & 74 & 1 \\
\hline & 11410000 & $01 / 30 / 02$ & 1040 & 70 & 2 \\
\hline & 11410000 & $01 / 31 / 02$ & 1100 & 68 & 1 \\
\hline & 11410000 & $01 / 31 / 02$ & 1100 & 68 & 2 \\
\hline & 11410000 & $02 / 04 / 02$ & 1045 & 63 & 1 \\
\hline & 11410000 & $02 / 11 / 02$ & 1020 & 65 & 2 \\
\hline & 11410000 & $02 / 13 / 02$ & 1100 & 65 & 2 \\
\hline & 11410000 & $02 / 14 / 02$ & 1045 & 65 & 1 \\
\hline & 11410000 & $02 / 14 / 02$ & 1045 & 65 & 2 \\
\hline & 11410000 & $02 / 15 / 02$ & 1030 & 65 & 1 \\
\hline & 11410000 & $02 / 19 / 02$ & 1020 & 82 & 2 \\
\hline & 11410000 & $02 / 20 / 02$ & 1020 & 1250 & 83 \\
\hline & 11410000 & $02 / 20 / 02$ & 1020 & 1250 & 84 \\
\hline & 11410000 & $02 / 21 / 02$ & 1020 & 326 & 7 \\
\hline
\end{tabular}


Table A1a. Suspended-sediment concentration samples and associated instantaneous streamflow for the Middle Yuba River near North San Juan (MYG) collected during water years 2001, 2002, and 2003.

[USGS Marina sediment laboratory uses $0.5 \mathrm{mg} / \mathrm{L}$ (milligram per liter) as the detection limit for reporting suspended-sediment concentration (SSC); therefore, samples with SSC of less than 0.5 $\mathrm{mg} / \mathrm{L}$ are reported as $0.25 \mathrm{mg} / \mathrm{L}$ (Helsel and Hirsch, 1992). $\mathrm{ft}^{3} / \mathrm{s}$, cubic feet per second]

\begin{tabular}{|c|c|c|c|c|c|}
\hline $\begin{array}{c}\text { Map } \\
\text { identifier }\end{array}$ & $\begin{array}{c}\text { Station } \\
\text { identifier }\end{array}$ & Date & Time & $\begin{array}{c}\text { Instan- } \\
\text { taneous } \\
\text { stream- } \\
\text { flow } \\
\left(\mathrm{ft}^{3} / \mathrm{s}\right)\end{array}$ & $\begin{array}{c}\text { Sus- } \\
\text { pended- } \\
\text { sediment } \\
\text { concen- } \\
\text { tration } \\
\text { (mg/L) }\end{array}$ \\
\hline \multirow[t]{45}{*}{ MYG } & 11410000 & $02 / 22 / 02$ & 1025 & 110 & 5 \\
\hline & 11410000 & $02 / 25 / 02$ & 1025 & 86 & 2 \\
\hline & 11410000 & $02 / 25 / 02$ & 1025 & 86 & 2 \\
\hline & 11410000 & $02 / 26 / 02$ & 1020 & 82 & 2 \\
\hline & 11410000 & 02/27/02 & 1025 & 82 & 1 \\
\hline & 11410000 & $02 / 27 / 02$ & 1025 & 82 & 1 \\
\hline & 11410000 & $02 / 28 / 02$ & 1035 & 80 & 4 \\
\hline & 11410000 & 03/01/02 & 1020 & 76 & 2 \\
\hline & 11410000 & 03/04/02 & 1010 & 70 & 1 \\
\hline & 11410000 & 03/04/02 & 1010 & 70 & 0.25 \\
\hline & 11410000 & 03/05/02 & 1010 & 70 & 2 \\
\hline & 11410000 & 03/06/02 & 1040 & 137 & 12 \\
\hline & 11410000 & 03/06/02 & 1040 & 137 & 8 \\
\hline & 11410000 & 03/06/02 & 1200 & 158 & 11 \\
\hline & 11410000 & 03/07/02 & 1015 & 399 & 13 \\
\hline & 11410000 & 03/07/02 & 1305 & 359 & 10 \\
\hline & 11410000 & 03/07/02 & 1305 & 359 & 7 \\
\hline & 11410000 & 03/08/02 & 1000 & 204 & 8 \\
\hline & 11410000 & 03/08/02 & 1000 & 204 & 14 \\
\hline & 11410000 & 03/08/02 & 1305 & 153 & 5 \\
\hline & 11410000 & 03/08/02 & 1305 & 153 & 6 \\
\hline & 11410000 & 03/11/02 & 1020 & 113 & 4 \\
\hline & 11410000 & 03/11/02 & 1020 & 113 & 3 \\
\hline & 11410000 & 03/12/02 & 1035 & 102 & 3 \\
\hline & 11410000 & $03 / 12 / 02$ & 1035 & 102 & 4 \\
\hline & 11410000 & 03/14/02 & 1010 & 90 & 2 \\
\hline & 11410000 & 03/14/02 & 1010 & 90 & 2 \\
\hline & 11410000 & 03/15/02 & 1020 & 86 & 3 \\
\hline & 11410000 & 03/15/02 & 1020 & 86 & 2 \\
\hline & 11410000 & 03/18/02 & 1015 & 70 & 2 \\
\hline & 11410000 & 03/18/02 & 1015 & 70 & 2 \\
\hline & 11410000 & 03/19/02 & 1015 & 68 & 1 \\
\hline & 11410000 & 03/19/02 & 1015 & 68 & 2 \\
\hline & 11410000 & 03/20/02 & 1010 & 68 & 1 \\
\hline & 11410000 & 03/20/02 & 1010 & 68 & 2 \\
\hline & 11410000 & 03/21/02 & 1010 & 66 & 1 \\
\hline & 11410000 & $03 / 21 / 02$ & 1010 & 66 & 2 \\
\hline & 11410000 & $03 / 22 / 02$ & 1025 & 65 & 2 \\
\hline & 11410000 & $03 / 22 / 02$ & 1025 & 65 & 1 \\
\hline & 11410000 & 03/24/02 & 1010 & 228 & 21 \\
\hline & 11410000 & $03 / 24 / 02$ & 1010 & 228 & 22 \\
\hline & 11410000 & $03 / 25 / 02$ & 0845 & 127 & 5 \\
\hline & 11410000 & $03 / 25 / 02$ & 0845 & 127 & 5 \\
\hline & 11410000 & 03/26/02 & 1025 & 102 & 5 \\
\hline & 11410000 & $03 / 26 / 02$ & 1025 & 102 & 3 \\
\hline
\end{tabular}

Table A1a. Suspended-sediment concentration samples and associated instantaneous streamflow for the Middle Yuba River near North San Juan (MYG) collected during water years 2001, 2002, and 2003.

[USGS Marina sediment laboratory uses $0.5 \mathrm{mg} / \mathrm{L}$ (milligram per liter) as the detection limit for reporting suspended-sediment concentration (SSC); therefore, samples with SSC of less than 0.5 $\mathrm{mg} / \mathrm{L}$ are reported as $0.25 \mathrm{mg} / \mathrm{L}$ (Helsel and Hirsch, 1992). $\mathrm{ft}^{3} / \mathrm{s}$, cubic feet per second]

\begin{tabular}{|c|c|c|c|c|c|}
\hline $\begin{array}{c}\text { Map } \\
\text { identifier }\end{array}$ & $\begin{array}{l}\text { Station } \\
\text { identifier }\end{array}$ & Date & Time & $\begin{array}{l}\text { Instan- } \\
\text { taneous } \\
\text { stream- } \\
\text { flow } \\
\left(\mathrm{ft}^{3} / \mathrm{s}\right)\end{array}$ & $\begin{array}{c}\text { Sus- } \\
\text { pended- } \\
\text { sediment } \\
\text { concen- } \\
\text { tration } \\
\text { (mg/L) }\end{array}$ \\
\hline \multirow[t]{45}{*}{ MYG } & 11410000 & $03 / 27 / 02$ & 1025 & 90 & 3 \\
\hline & 11410000 & 03/27/02 & 1025 & 90 & 3 \\
\hline & 11410000 & 03/28/02 & 1025 & 84 & 5 \\
\hline & 11410000 & 03/28/02 & 1025 & 84 & 4 \\
\hline & 11410000 & 03/29/02 & 1025 & 82 & 2 \\
\hline & 11410000 & 03/29/02 & 1025 & 82 & 3 \\
\hline & 11410000 & $04 / 02 / 02$ & 1100 & 70 & 3 \\
\hline & 11410000 & 04/02/02 & 1100 & 70 & 2 \\
\hline & 11410000 & 04/03/02 & 1025 & 70 & 2 \\
\hline & 11410000 & 04/03/02 & 1025 & 70 & 2 \\
\hline & 11410000 & 04/04/02 & 1020 & 70 & 2 \\
\hline & 11410000 & $04 / 04 / 02$ & 1020 & 70 & 1 \\
\hline & 11410000 & $04 / 05 / 02$ & 1025 & 68 & 2 \\
\hline & 11410000 & 04/05/02 & 1025 & 68 & 2 \\
\hline & 11410000 & 04/08/02 & 1025 & 61 & 1 \\
\hline & 11410000 & 04/08/02 & 1025 & 61 & 2 \\
\hline & 11410000 & 04/09/02 & 1035 & 61 & 3 \\
\hline & 11410000 & 04/09/02 & 1035 & 61 & 2 \\
\hline & 11410000 & 04/10/02 & 1010 & 61 & 2 \\
\hline & 11410000 & 04/10/02 & 1010 & 61 & 3 \\
\hline & 11410000 & $04 / 11 / 02$ & 1010 & 61 & 2 \\
\hline & 11410000 & $04 / 11 / 02$ & 1010 & 61 & 3 \\
\hline & 11410000 & $04 / 15 / 02$ & 1015 & 88 & 3 \\
\hline & 11410000 & $04 / 15 / 02$ & 1015 & 88 & 4 \\
\hline & 11410000 & 04/16/02 & 1005 & 82 & 3 \\
\hline & 11410000 & $04 / 16 / 02$ & 1005 & 82 & 1 \\
\hline & 11410000 & 04/17/02 & 1015 & 86 & 2 \\
\hline & 11410000 & $04 / 17 / 02$ & 1015 & 86 & 3 \\
\hline & 11410000 & 04/18/02 & 1010 & 84 & 2 \\
\hline & 11410000 & 04/18/02 & 1010 & 84 & 1 \\
\hline & 11410000 & 04/19/02 & 1015 & 82 & 1 \\
\hline & 11410000 & 04/19/02 & 1015 & 82 & 1 \\
\hline & 11410000 & $04 / 22 / 02$ & 1000 & 82 & 2 \\
\hline & 11410000 & $04 / 22 / 02$ & 1000 & 82 & 2 \\
\hline & 11410000 & $04 / 23 / 02$ & 1020 & 82 & 2 \\
\hline & 11410000 & $04 / 23 / 02$ & 1020 & 82 & 3 \\
\hline & 11410000 & $04 / 24 / 02$ & 1000 & 82 & 2 \\
\hline & 11410000 & $04 / 24 / 02$ & 1000 & 82 & 3 \\
\hline & 11410000 & $04 / 25 / 02$ & 1010 & 80 & 2 \\
\hline & 11410000 & $04 / 25 / 02$ & 1010 & 80 & 2 \\
\hline & 11410000 & $04 / 26 / 02$ & 1005 & 84 & 3 \\
\hline & 11410000 & 04/26/02 & 1005 & 84 & 1 \\
\hline & 11410000 & 04/30/02 & 1025 & 82 & 3 \\
\hline & 11410000 & 04/30/02 & 1025 & 82 & 2 \\
\hline & 11410000 & 05/01/02 & 0955 & 82 & 6 \\
\hline
\end{tabular}


Table A1a. Suspended-sediment concentration samples and associated instantaneous streamflow for the Middle Yuba River near North San Juan (MYG) collected during water years 2001, 2002, and 2003.

[USGS Marina sediment laboratory uses $0.5 \mathrm{mg} / \mathrm{L}$ (milligram per liter) as the detection limit for reporting suspended-sediment concentration (SSC); therefore, samples with SSC of less than 0.5 $\mathrm{mg} / \mathrm{L}$ are reported as $0.25 \mathrm{mg} / \mathrm{L}$ (Helsel and Hirsch, 1992). $\mathrm{ft}^{3} / \mathrm{s}$, cubic feet per second]

\begin{tabular}{|c|c|c|c|c|c|}
\hline $\begin{array}{c}\text { Map } \\
\text { identifier }\end{array}$ & $\begin{array}{l}\text { Station } \\
\text { identifier }\end{array}$ & Date & Time & $\begin{array}{c}\text { Instan- } \\
\text { taneous } \\
\text { stream- } \\
\text { flow } \\
\left(\mathrm{ft}^{3} / \mathrm{s}\right)\end{array}$ & $\begin{array}{c}\text { Sus- } \\
\text { pended- } \\
\text { sediment } \\
\text { concen- } \\
\text { tration } \\
(\mathrm{mg} / \mathrm{L})\end{array}$ \\
\hline \multirow[t]{45}{*}{ MYG } & 11410000 & $05 / 01 / 02$ & 0955 & 82 & 1 \\
\hline & 11410000 & $05 / 02 / 02$ & 1005 & 82 & 1 \\
\hline & 11410000 & $05 / 02 / 02$ & 1005 & 82 & 2 \\
\hline & 11410000 & $05 / 03 / 02$ & 0955 & 80 & 2 \\
\hline & 11410000 & $05 / 03 / 02$ & 0955 & 80 & 2 \\
\hline & 11410000 & $05 / 06 / 02$ & 1015 & 82 & 2 \\
\hline & 11410000 & $05 / 06 / 02$ & 1015 & 82 & 3 \\
\hline & 11410000 & $05 / 07 / 02$ & 1020 & 82 & 2 \\
\hline & 11410000 & $05 / 07 / 02$ & 1020 & 82 & 2 \\
\hline & 11410000 & 05/08/02 & 1025 & 82 & 2 \\
\hline & 11410000 & $05 / 08 / 02$ & 1025 & 82 & 2 \\
\hline & 11410000 & 05/09/02 & 1020 & 82 & 1 \\
\hline & 11410000 & $05 / 09 / 02$ & 1020 & 82 & 1 \\
\hline & 11410000 & $05 / 10 / 02$ & 1005 & 80 & 2 \\
\hline & 11410000 & $05 / 10 / 02$ & 1005 & 80 & 1 \\
\hline & 11410000 & $05 / 13 / 02$ & 1010 & 78 & 1 \\
\hline & 11410000 & $05 / 13 / 02$ & 1010 & 78 & 1 \\
\hline & 11410000 & $05 / 14 / 02$ & 1025 & 78 & 3 \\
\hline & 11410000 & $05 / 14 / 02$ & 1025 & 78 & 2 \\
\hline & 11410000 & $05 / 15 / 02$ & 1020 & 80 & 1 \\
\hline & 11410000 & $05 / 15 / 02$ & 1020 & 80 & 2 \\
\hline & 11410000 & $05 / 16 / 02$ & 1035 & 80 & 2 \\
\hline & 11410000 & $05 / 16 / 02$ & 1035 & 80 & 4 \\
\hline & 11410000 & $05 / 17 / 02$ & 1020 & 80 & 2 \\
\hline & 11410000 & $05 / 17 / 02$ & 1020 & 80 & 3 \\
\hline & 11410000 & $05 / 20 / 02$ & 1020 & 90 & 4 \\
\hline & 11410000 & $05 / 20 / 02$ & 1020 & 90 & 4 \\
\hline & 11410000 & $05 / 21 / 02$ & 1030 & 86 & 4 \\
\hline & 11410000 & $05 / 21 / 02$ & 1030 & 86 & 2 \\
\hline & 11410000 & $05 / 22 / 02$ & 1015 & 82 & 2 \\
\hline & 11410000 & $05 / 22 / 02$ & 1015 & 82 & 3 \\
\hline & 11410000 & $05 / 23 / 02$ & 1035 & 80 & 2 \\
\hline & 11410000 & $05 / 23 / 02$ & 1035 & 80 & 2 \\
\hline & 11410000 & $05 / 24 / 02$ & 1010 & 78 & 3 \\
\hline & 11410000 & $05 / 24 / 02$ & 1010 & 78 & 4 \\
\hline & 11410000 & $05 / 28 / 02$ & 1015 & 80 & 4 \\
\hline & 11410000 & $05 / 28 / 02$ & 1015 & 80 & 2 \\
\hline & 11410000 & $05 / 29 / 02$ & 1020 & 80 & 1 \\
\hline & 11410000 & $05 / 29 / 02$ & 1020 & 80 & 1 \\
\hline & 11410000 & $05 / 30 / 02$ & 1000 & 82 & 2 \\
\hline & 11410000 & $05 / 30 / 02$ & 1000 & 82 & 1 \\
\hline & 11410000 & $05 / 31 / 02$ & 1015 & 82 & 1 \\
\hline & 11410000 & $05 / 31 / 02$ & 1015 & 82 & 2 \\
\hline & 11410000 & $06 / 04 / 02$ & 1530 & 74 & 1 \\
\hline & 11410000 & $06 / 04 / 02$ & 1530 & 74 & 1 \\
\hline
\end{tabular}

Table A1a. Suspended-sediment concentration samples and associated instantaneous streamflow for the Middle Yuba River near North San Juan (MYG) collected during water years 2001, 2002, and 2003.

[USGS Marina sediment laboratory uses $0.5 \mathrm{mg} / \mathrm{L}$ (milligram per liter) as the detection limit for reporting suspended-sediment concentration (SSC); therefore, samples with SSC of less than 0.5 $\mathrm{mg} / \mathrm{L}$ are reported as $0.25 \mathrm{mg} / \mathrm{L}$ (Helsel and Hirsch, 1992). $\mathrm{ft}^{3} / \mathrm{s}$, cubic feet per second]

\begin{tabular}{|c|c|c|c|c|c|}
\hline $\begin{array}{c}\text { Map } \\
\text { identifier }\end{array}$ & $\begin{array}{l}\text { Station } \\
\text { identifier }\end{array}$ & Date & Time & $\begin{array}{c}\text { Instan- } \\
\text { taneous } \\
\text { stream- } \\
\text { flow } \\
\left(\mathrm{ft}^{3} / \mathrm{s}\right)\end{array}$ & $\begin{array}{c}\text { Sus- } \\
\text { pended- } \\
\text { sediment } \\
\text { concen- } \\
\text { tration } \\
\text { (mg/L) }\end{array}$ \\
\hline \multirow[t]{45}{*}{ MYG } & 11410000 & $06 / 06 / 02$ & 1350 & 74 & 4 \\
\hline & 11410000 & 06/06/02 & 1350 & 74 & 3 \\
\hline & 11410000 & $06 / 10 / 02$ & 1025 & 76 & 2 \\
\hline & 11410000 & $06 / 10 / 02$ & 1025 & 76 & 1 \\
\hline & 11410000 & $06 / 11 / 02$ & 1025 & 76 & 3 \\
\hline & 11410000 & $06 / 11 / 02$ & 1025 & 76 & 3 \\
\hline & 11410000 & $06 / 12 / 02$ & 1015 & 74 & 3 \\
\hline & 11410000 & $06 / 12 / 02$ & 1015 & 74 & 3 \\
\hline & 11410000 & $06 / 13 / 02$ & 1030 & 72 & 1 \\
\hline & 11410000 & $06 / 13 / 02$ & 1030 & 72 & 2 \\
\hline & 11410000 & $06 / 14 / 02$ & 1020 & 72 & 2 \\
\hline & 11410000 & $06 / 14 / 02$ & 1020 & 72 & 1 \\
\hline & 11410000 & $06 / 17 / 02$ & 1025 & 53 & 2 \\
\hline & 11410000 & $06 / 17 / 02$ & 1025 & 53 & 2 \\
\hline & 11410000 & $06 / 18 / 02$ & 1025 & 53 & 1 \\
\hline & 11410000 & $06 / 18 / 02$ & 1025 & 53 & 1 \\
\hline & 11410000 & $06 / 19 / 02$ & 1000 & 53 & 5 \\
\hline & 11410000 & $06 / 19 / 02$ & 1000 & 53 & 2 \\
\hline & 11410000 & $06 / 20 / 02$ & 1005 & 53 & 2 \\
\hline & 11410000 & 06/20/02 & 1005 & 53 & 1 \\
\hline & 11410000 & $06 / 21 / 02$ & 0930 & 52 & 3 \\
\hline & 11410000 & $06 / 21 / 02$ & 0930 & 52 & 3 \\
\hline & 11410000 & $06 / 24 / 02$ & 1020 & 52 & 2 \\
\hline & 11410000 & $06 / 24 / 02$ & 1020 & 52 & 4 \\
\hline & 11410000 & $06 / 25 / 02$ & 1015 & 51 & 4 \\
\hline & 11410000 & $06 / 25 / 02$ & 1015 & 51 & 3 \\
\hline & 11410000 & $06 / 27 / 02$ & 1010 & 51 & 1 \\
\hline & 11410000 & $06 / 27 / 02$ & 1010 & 51 & 2 \\
\hline & 11410000 & $06 / 28 / 02$ & 1020 & 49 & 2 \\
\hline & 11410000 & $06 / 28 / 02$ & 1020 & 49 & 2 \\
\hline & 11410000 & $11 / 05 / 02$ & 1220 & 33 & 0.25 \\
\hline & 11410000 & $11 / 05 / 02$ & 1220 & 33 & 0.25 \\
\hline & 11410000 & $11 / 07 / 02$ & 1030 & 43 & 1 \\
\hline & 11410000 & $11 / 07 / 02$ & 1030 & 43 & 0.25 \\
\hline & 11410000 & $11 / 07 / 02$ & 1230 & 42 & 1 \\
\hline & 11410000 & $11 / 07 / 02$ & 1230 & 42 & 2 \\
\hline & 11410000 & $11 / 07 / 02$ & 1430 & 40 & 2 \\
\hline & 11410000 & $11 / 07 / 02$ & 1430 & 40 & 8 \\
\hline & 11410000 & $11 / 07 / 02$ & 1600 & 43 & 2 \\
\hline & 11410000 & $11 / 07 / 02$ & 1600 & 43 & 3 \\
\hline & 11410000 & $11 / 08 / 02$ & 0800 & 51 & 6 \\
\hline & 11410000 & $11 / 08 / 02$ & 0800 & 51 & 5 \\
\hline & 11410000 & $11 / 08 / 02$ & 1000 & 56 & 4 \\
\hline & 11410000 & $11 / 08 / 02$ & 1000 & 56 & 5 \\
\hline & 11410000 & $11 / 08 / 02$ & 1200 & 74 & 26 \\
\hline
\end{tabular}


Table A1a. Suspended-sediment concentration samples and associated instantaneous streamflow for the Middle Yuba River near North San Juan (MYG) collected during water years 2001, 2002, and 2003.

[USGS Marina sediment laboratory uses $0.5 \mathrm{mg} / \mathrm{L}$ (milligram per liter) as the detection limit for reporting suspended-sediment concentration (SSC); therefore, samples with SSC of less than 0.5 $\mathrm{mg} / \mathrm{L}$ are reported as $0.25 \mathrm{mg} / \mathrm{L}$ (Helsel and Hirsch, 1992). $\mathrm{ft}^{3} / \mathrm{s}$, cubic feet per second]

\begin{tabular}{|c|c|c|c|c|c|}
\hline $\begin{array}{c}\text { Map } \\
\text { identifier }\end{array}$ & $\begin{array}{c}\text { Station } \\
\text { identifier }\end{array}$ & Date & Time & $\begin{array}{c}\text { Instan- } \\
\text { taneous } \\
\text { stream- } \\
\text { flow } \\
\left(\mathrm{ft}^{3} / \mathrm{s}\right)\end{array}$ & $\begin{array}{c}\text { Sus- } \\
\text { pended- } \\
\text { sediment } \\
\text { concen- } \\
\text { tration } \\
\text { (mg/L) }\end{array}$ \\
\hline \multirow[t]{45}{*}{ MYG } & 11410000 & $11 / 08 / 02$ & 1200 & 74 & 25 \\
\hline & 11410000 & $11 / 08 / 02$ & 1400 & 82 & 84 \\
\hline & 11410000 & $11 / 08 / 02$ & 1400 & 82 & 91 \\
\hline & 11410000 & $11 / 08 / 02$ & 1600 & 76 & 45 \\
\hline & 11410000 & $11 / 08 / 02$ & 1600 & 76 & 47 \\
\hline & 11410000 & $11 / 09 / 02$ & 0831 & 58 & 94 \\
\hline & 11410000 & $11 / 09 / 02$ & 0831 & 58 & 96 \\
\hline & 11410000 & $11 / 09 / 02$ & 1000 & 58 & 95 \\
\hline & 11410000 & $11 / 09 / 02$ & 1000 & 58 & 105 \\
\hline & 11410000 & $11 / 09 / 02$ & 1200 & 56 & 39 \\
\hline & 11410000 & $11 / 09 / 02$ & 1200 & 56 & 46 \\
\hline & 11410000 & $11 / 12 / 02$ & 1405 & 53 & 5 \\
\hline & 11410000 & $11 / 12 / 02$ & 1405 & 53 & 4 \\
\hline & 11410000 & $11 / 13 / 02$ & 1045 & 52 & 2 \\
\hline & 11410000 & $11 / 13 / 02$ & 1045 & 52 & 2 \\
\hline & 11410000 & $11 / 15 / 02$ & 1040 & 47 & 3 \\
\hline & 11410000 & $11 / 15 / 02$ & 1040 & 47 & 2 \\
\hline & 11410000 & $11 / 18 / 02$ & 1028 & 51 & 1 \\
\hline & 11410000 & $11 / 18 / 02$ & 1028 & 51 & 1 \\
\hline & 11410000 & $11 / 20 / 02$ & 1100 & 51 & 0.25 \\
\hline & 11410000 & $11 / 20 / 02$ & 1100 & 51 & 1 \\
\hline & 11410000 & $11 / 22 / 02$ & 1050 & 49 & 1 \\
\hline & 11410000 & $11 / 22 / 02$ & 1050 & 49 & 1 \\
\hline & 11410000 & $11 / 25 / 02$ & 1030 & 49 & 0.25 \\
\hline & 11410000 & $11 / 25 / 02$ & 1030 & 49 & 1 \\
\hline & 11410000 & $11 / 27 / 02$ & 1045 & 45 & 0.25 \\
\hline & 11410000 & $11 / 27 / 02$ & 1045 & 45 & 0.25 \\
\hline & 11410000 & $12 / 02 / 02$ & 1040 & 47 & 5 \\
\hline & 11410000 & $12 / 02 / 02$ & 1040 & 47 & 4 \\
\hline & 11410000 & $12 / 04 / 02$ & 1020 & 47 & 2 \\
\hline & 11410000 & $12 / 04 / 02$ & 1020 & 47 & 0.25 \\
\hline & 11410000 & $12 / 06 / 02$ & 1030 & 47 & 1 \\
\hline & 11410000 & $12 / 06 / 02$ & 1030 & 47 & 0.25 \\
\hline & 11410000 & $12 / 09 / 02$ & 1025 & 47 & 1 \\
\hline & 11410000 & $12 / 09 / 02$ & 1025 & 47 & 0.25 \\
\hline & 11410000 & $12 / 11 / 02$ & 1030 & 49 & 0.25 \\
\hline & 11410000 & $12 / 11 / 02$ & 1030 & 49 & 1 \\
\hline & 11410000 & $12 / 12 / 02$ & 0900 & 47 & 1 \\
\hline & 11410000 & $12 / 12 / 02$ & 0900 & 47 & 1 \\
\hline & 11410000 & $12 / 13 / 02$ & 0800 & 80 & 4 \\
\hline & 11410000 & $12 / 13 / 02$ & 0800 & 80 & 5 \\
\hline & 11410000 & $12 / 13 / 02$ & 1000 & 84 & 6 \\
\hline & 11410000 & $12 / 13 / 02$ & 1000 & 84 & 6 \\
\hline & 11410000 & $12 / 13 / 02$ & 1200 & 84 & 5 \\
\hline & 11410000 & $12 / 13 / 02$ & 1200 & 84 & 8 \\
\hline
\end{tabular}

Table A1a. Suspended-sediment concentration samples and associated instantaneous streamflow for the Middle Yuba River near North San Juan (MYG) collected during water years 2001, 2002, and 2003.

[USGS Marina sediment laboratory uses $0.5 \mathrm{mg} / \mathrm{L}$ (milligram per liter) as the detection limit for reporting suspended-sediment concentration (SSC); therefore, samples with SSC of less than 0.5 $\mathrm{mg} / \mathrm{L}$ are reported as $0.25 \mathrm{mg} / \mathrm{L}$ (Helsel and Hirsch, 1992). $\mathrm{ft}^{3} / \mathrm{s}$, cubic feet per second]

\begin{tabular}{|c|c|c|c|c|c|}
\hline $\begin{array}{l}\text { Map } \\
\text { identifier }\end{array}$ & $\begin{array}{l}\text { Station } \\
\text { identifier }\end{array}$ & Date & Time & $\begin{array}{l}\text { Instan- } \\
\text { taneous } \\
\text { stream- } \\
\text { flow } \\
\left(\mathrm{ft}^{3} / \mathrm{s}\right)\end{array}$ & $\begin{array}{c}\text { Sus- } \\
\text { pended- } \\
\text { sediment } \\
\text { concen- } \\
\text { tration } \\
\text { (mg/L) }\end{array}$ \\
\hline \multirow[t]{45}{*}{ MYG } & 11410000 & $12 / 13 / 02$ & 1400 & 90 & 5 \\
\hline & 11410000 & $12 / 13 / 02$ & 1400 & 90 & 4 \\
\hline & 11410000 & $12 / 13 / 02$ & 1530 & 110 & 9 \\
\hline & 11410000 & $12 / 13 / 02$ & 1530 & 110 & 14 \\
\hline & 11410000 & $12 / 13 / 02$ & 1630 & 137 & 7 \\
\hline & 11410000 & $12 / 13 / 02$ & 1630 & 137 & 8 \\
\hline & 11410000 & $12 / 14 / 02$ & 1000 & 1250 & 85 \\
\hline & 11410000 & $12 / 14 / 02$ & 1000 & 1250 & 85 \\
\hline & 11410000 & $12 / 14 / 02$ & 1325 & 1090 & 57 \\
\hline & 11410000 & $12 / 14 / 02$ & 1325 & 1090 & 63 \\
\hline & 11410000 & $12 / 14 / 02$ & 1632 & 706 & 181 \\
\hline & 11410000 & $12 / 14 / 02$ & 1632 & 706 & 159 \\
\hline & 11410000 & $12 / 15 / 02$ & 0730 & 883 & 47 \\
\hline & 11410000 & $12 / 15 / 02$ & 0730 & 883 & 52 \\
\hline & 11410000 & $12 / 15 / 02$ & 0830 & 778 & 41 \\
\hline & 11410000 & $12 / 15 / 02$ & 0830 & 778 & 42 \\
\hline & 11410000 & $12 / 15 / 02$ & 0941 & 680 & 11 \\
\hline & 11410000 & $12 / 15 / 02$ & 1036 & 602 & 33 \\
\hline & 11410000 & $12 / 15 / 02$ & 1036 & 602 & 33 \\
\hline & 11410000 & $12 / 15 / 02$ & 1130 & 528 & 30 \\
\hline & 11410000 & $12 / 15 / 02$ & 1130 & 528 & 32 \\
\hline & 11410000 & $12 / 15 / 02$ & 1233 & 464 & 32 \\
\hline & 11410000 & $12 / 15 / 02$ & 1233 & 464 & 28 \\
\hline & 11410000 & $12 / 15 / 02$ & 1328 & 423 & 24 \\
\hline & 11410000 & $12 / 15 / 02$ & 1328 & 423 & 26 \\
\hline & 11410000 & $12 / 15 / 02$ & 1328 & 423 & 27 \\
\hline & 11410000 & $12 / 15 / 02$ & 1434 & 346 & 26 \\
\hline & 11410000 & $12 / 15 / 02$ & 1434 & 346 & 23 \\
\hline & 11410000 & $12 / 15 / 02$ & 1536 & 297 & 22 \\
\hline & 11410000 & $12 / 15 / 02$ & 1536 & 297 & 20 \\
\hline & 11410000 & $12 / 15 / 02$ & 1630 & 255 & 19 \\
\hline & 11410000 & $12 / 15 / 02$ & 1630 & 255 & 22 \\
\hline & 11410000 & $12 / 16 / 02$ & 0900 & 2100 & 309 \\
\hline & 11410000 & $12 / 16 / 02$ & 0900 & 2100 & 329 \\
\hline & 11410000 & $12 / 16 / 02$ & 1100 & 1900 & 389 \\
\hline & 11410000 & $12 / 16 / 02$ & 1100 & 1900 & 406 \\
\hline & 11410000 & $12 / 16 / 02$ & 1300 & 1990 & 269 \\
\hline & 11410000 & $12 / 16 / 02$ & 1300 & 1990 & 275 \\
\hline & 11410000 & $12 / 16 / 02$ & 1500 & 2260 & 1870 \\
\hline & 11410000 & $12 / 16 / 02$ & 1500 & 2260 & 1857 \\
\hline & 11410000 & $12 / 16 / 02$ & 1600 & 2160 & 1054 \\
\hline & 11410000 & $12 / 16 / 02$ & 1600 & 2160 & 1057 \\
\hline & 11410000 & $12 / 17 / 02$ & 0815 & 359 & 61 \\
\hline & 11410000 & $12 / 17 / 02$ & 0815 & 359 & 59 \\
\hline & 11410000 & $12 / 17 / 02$ & 1000 & 280 & 50 \\
\hline
\end{tabular}


Table A1a. Suspended-sediment concentration samples and associated instantaneous streamflow for the Middle Yuba River near North San Juan (MYG) collected during water years 2001, 2002, and 2003.

[USGS Marina sediment laboratory uses $0.5 \mathrm{mg} / \mathrm{L}$ (milligram per liter) as the detection limit for reporting suspended-sediment concentration (SSC); therefore, samples with SSC of less than 0.5 $\mathrm{mg} / \mathrm{L}$ are reported as $0.25 \mathrm{mg} / \mathrm{L}$ (Helsel and Hirsch, 1992). $\mathrm{ft}^{3} / \mathrm{s}$, cubic feet per second]

\begin{tabular}{|c|c|c|c|c|c|}
\hline $\begin{array}{c}\text { Map } \\
\text { identifier }\end{array}$ & $\begin{array}{l}\text { Station } \\
\text { identifier }\end{array}$ & Date & Time & $\begin{array}{c}\text { Instan- } \\
\text { taneous } \\
\text { stream- } \\
\text { flow } \\
\left(\mathrm{ft}^{3} / \mathrm{s}\right)\end{array}$ & $\begin{array}{c}\text { Sus- } \\
\text { pended- } \\
\text { sediment } \\
\text { concen- } \\
\text { tration } \\
\text { (mg/L) }\end{array}$ \\
\hline \multirow[t]{45}{*}{ MYG } & 11410000 & $12 / 17 / 02$ & 1000 & 280 & 54 \\
\hline & 11410000 & $12 / 17 / 02$ & 1200 & 204 & 39 \\
\hline & 11410000 & $12 / 17 / 02$ & 1200 & 204 & 47 \\
\hline & 11410000 & $12 / 17 / 02$ & 1300 & 177 & 38 \\
\hline & 11410000 & $12 / 17 / 02$ & 1300 & 177 & 36 \\
\hline & 11410000 & $12 / 17 / 02$ & 1515 & 147 & 25 \\
\hline & 11410000 & $12 / 17 / 02$ & 1515 & 147 & 28 \\
\hline & 11410000 & $12 / 17 / 02$ & 1600 & 142 & 25 \\
\hline & 11410000 & $12 / 17 / 02$ & 1600 & 142 & 26 \\
\hline & 11410000 & $12 / 18 / 02$ & 0900 & 97 & 11 \\
\hline & 11410000 & $12 / 18 / 02$ & 0900 & 97 & 9 \\
\hline & 11410000 & $12 / 20 / 02$ & 1030 & 82 & 5 \\
\hline & 11410000 & $12 / 20 / 02$ & 1030 & 82 & 5 \\
\hline & 11410000 & $12 / 23 / 02$ & 1020 & 86 & 3 \\
\hline & 11410000 & $12 / 27 / 02$ & 1021 & 142 & 5 \\
\hline & 11410000 & $12 / 27 / 02$ & 1021 & 142 & 5 \\
\hline & 11410000 & $12 / 31 / 02$ & 0900 & 232 & 44 \\
\hline & 11410000 & $12 / 31 / 02$ & 0900 & 232 & 42 \\
\hline & 11410000 & $01 / 03 / 03$ & 1050 & 88 & 2 \\
\hline & 11410000 & $01 / 03 / 03$ & 1050 & 88 & 1 \\
\hline & 11410000 & 01/06/03 & 1050 & 76 & 2 \\
\hline & 11410000 & 01/06/03 & 1050 & 76 & 2 \\
\hline & 11410000 & 01/08/03 & 0950 & 72 & 2 \\
\hline & 11410000 & 01/08/03 & 0950 & 72 & 1 \\
\hline & 11410000 & 01/10/03 & 1050 & 88 & 6 \\
\hline & 11410000 & 01/10/03 & 1050 & 88 & 6 \\
\hline & 11410000 & 01/13/03 & 1100 & 88 & 2 \\
\hline & 11410000 & $01 / 13 / 03$ & 1105 & 88 & 1 \\
\hline & 11410000 & $01 / 15 / 03$ & 0915 & 78 & 2 \\
\hline & 11410000 & $01 / 15 / 03$ & 0915 & 78 & 1 \\
\hline & 11410000 & 01/17/03 & 1230 & 74 & 1 \\
\hline & 11410000 & $01 / 17 / 03$ & 1230 & 74 & 2 \\
\hline & 11410000 & $01 / 21 / 03$ & 1040 & 78 & 0.25 \\
\hline & 11410000 & $01 / 21 / 03$ & 1040 & 78 & 1 \\
\hline & 11410000 & $01 / 23 / 03$ & 1015 & 342 & 28 \\
\hline & 11410000 & $01 / 23 / 03$ & 1015 & 342 & 28 \\
\hline & 11410000 & $01 / 27 / 03$ & 1055 & 88 & 2 \\
\hline & 11410000 & $01 / 27 / 03$ & 1055 & 88 & 3 \\
\hline & 11410000 & $01 / 31 / 03$ & 1105 & 76 & 2 \\
\hline & 11410000 & $01 / 31 / 03$ & 1105 & 76 & 2 \\
\hline & 11410000 & $02 / 03 / 03$ & 1125 & 72 & 0.25 \\
\hline & 11410000 & 02/03/03 & 1125 & 72 & 0.25 \\
\hline & 11410000 & $02 / 05 / 03$ & 0850 & 68 & 3 \\
\hline & 11410000 & $02 / 05 / 03$ & 0850 & 68 & 2 \\
\hline & 11410000 & 02/07/03 & 1050 & 65 & 1 \\
\hline
\end{tabular}

Table A1a. Suspended-sediment concentration samples and associated instantaneous streamflow for the Middle Yuba River near North San Juan (MYG) collected during water years 2001, 2002, and 2003.

[USGS Marina sediment laboratory uses $0.5 \mathrm{mg} / \mathrm{L}$ (milligram per liter) as the detection limit for reporting suspended-sediment concentration (SSC); therefore, samples with SSC of less than 0.5 $\mathrm{mg} / \mathrm{L}$ are reported as $0.25 \mathrm{mg} / \mathrm{L}$ (Helsel and Hirsch, 1992). $\mathrm{ft}^{3} / \mathrm{s}$, cubic feet per second]

\begin{tabular}{|c|c|c|c|c|c|}
\hline $\begin{array}{c}\text { Map } \\
\text { identifier }\end{array}$ & $\begin{array}{l}\text { Station } \\
\text { identifier }\end{array}$ & Date & Time & $\begin{array}{c}\text { Instan- } \\
\text { taneous } \\
\text { stream- } \\
\text { flow } \\
\left(\mathrm{ft}^{3} / \mathrm{s}\right)\end{array}$ & $\begin{array}{c}\text { Sus- } \\
\text { pended- } \\
\text { sediment } \\
\text { concen- } \\
\text { tration } \\
\text { (mg/L) }\end{array}$ \\
\hline \multirow[t]{45}{*}{ MYG } & 11410000 & $02 / 07 / 03$ & 1050 & 65 & 2 \\
\hline & 11410000 & $02 / 10 / 03$ & 0915 & 63 & 1 \\
\hline & 11410000 & $02 / 10 / 03$ & 0915 & 63 & 1 \\
\hline & 11410000 & $02 / 12 / 03$ & 0920 & 61 & 2 \\
\hline & 11410000 & $02 / 12 / 03$ & 0920 & 61 & 1 \\
\hline & 11410000 & $02 / 14 / 03$ & 0830 & 74 & 4 \\
\hline & 11410000 & $02 / 14 / 03$ & 0830 & 74 & 3 \\
\hline & 11410000 & $02 / 15 / 03$ & 1215 & 68 & 2 \\
\hline & 11410000 & $02 / 15 / 03$ & 1215 & 68 & 2 \\
\hline & 11410000 & $02 / 15 / 03$ & 1400 & 68 & 1 \\
\hline & 11410000 & $02 / 15 / 03$ & 1400 & 68 & 3 \\
\hline & 11410000 & $02 / 15 / 03$ & 1530 & 68 & 2 \\
\hline & 11410000 & $02 / 15 / 03$ & 1530 & 68 & 2 \\
\hline & 11410000 & $02 / 16 / 03$ & 0730 & 164 & 10 \\
\hline & 11410000 & $02 / 16 / 03$ & 0730 & 164 & 13 \\
\hline & 11410000 & $02 / 16 / 03$ & 0930 & 140 & 17 \\
\hline & 11410000 & $02 / 16 / 03$ & 0930 & 140 & 17 \\
\hline & 11410000 & $02 / 16 / 03$ & 1130 & 122 & 114 \\
\hline & 11410000 & $02 / 16 / 03$ & 1130 & 122 & 136 \\
\hline & 11410000 & $02 / 16 / 03$ & 1330 & 113 & 149 \\
\hline & 11410000 & $02 / 16 / 03$ & 1530 & 108 & 23 \\
\hline & 11410000 & $02 / 16 / 03$ & 1530 & 108 & 24 \\
\hline & 11410000 & $02 / 17 / 03$ & 0730 & 86 & 5 \\
\hline & 11410000 & $02 / 17 / 03$ & 0730 & 86 & 4 \\
\hline & 11410000 & $02 / 17 / 03$ & 0930 & 86 & 6 \\
\hline & 11410000 & $02 / 17 / 03$ & 0930 & 86 & 7 \\
\hline & 11410000 & $02 / 17 / 03$ & 1330 & 84 & 7 \\
\hline & 11410000 & $02 / 17 / 03$ & 1330 & 84 & 7 \\
\hline & 11410000 & $02 / 18 / 03$ & 0830 & 78 & 3 \\
\hline & 11410000 & $02 / 18 / 03$ & 0830 & 78 & 2 \\
\hline & 11410000 & $02 / 18 / 03$ & 1030 & 76 & 3 \\
\hline & 11410000 & $02 / 18 / 03$ & 1030 & 76 & 3 \\
\hline & 11410000 & $02 / 19 / 03$ & 1115 & 82 & 1 \\
\hline & 11410000 & $02 / 19 / 03$ & 1115 & 82 & 1 \\
\hline & 11410000 & $02 / 21 / 03$ & 1045 & 72 & 2 \\
\hline & 11410000 & $02 / 21 / 03$ & 1045 & 72 & 2 \\
\hline & 11410000 & $02 / 24 / 03$ & 1020 & 68 & 1 \\
\hline & 11410000 & $02 / 24 / 03$ & 1020 & 68 & 1 \\
\hline & 11410000 & $02 / 26 / 03$ & 1100 & 66 & 2 \\
\hline & 11410000 & $02 / 26 / 03$ & 1100 & 66 & 2 \\
\hline & 11410000 & $02 / 28 / 03$ & 1030 & 65 & 4 \\
\hline & 11410000 & $02 / 28 / 03$ & 1030 & 65 & 3 \\
\hline & 11410000 & $03 / 05 / 03$ & 1040 & 61 & 2 \\
\hline & 11410000 & $03 / 05 / 03$ & 1040 & 61 & 4 \\
\hline & 11410000 & 03/07/03 & 1015 & 60 & 3 \\
\hline
\end{tabular}


Table A1a. Suspended-sediment concentration samples and associated instantaneous streamflow for the Middle Yuba River near North San Juan (MYG) collected during water years 2001, 2002, and 2003.

[USGS Marina sediment laboratory uses $0.5 \mathrm{mg} / \mathrm{L}$ (milligram per liter) as the detection limit for reporting suspended-sediment concentration (SSC); therefore, samples with SSC of less than 0.5 $\mathrm{mg} / \mathrm{L}$ are reported as $0.25 \mathrm{mg} / \mathrm{L}$ (Helsel and Hirsch, 1992). $\mathrm{ft}^{3} / \mathrm{s}$, cubic feet per second]

\begin{tabular}{|c|c|c|c|c|c|}
\hline $\begin{array}{c}\text { Map } \\
\text { identifier }\end{array}$ & $\begin{array}{l}\text { Station } \\
\text { identifier }\end{array}$ & Date & Time & $\begin{array}{c}\text { Instan- } \\
\text { taneous } \\
\text { stream- } \\
\text { flow } \\
\left(\mathrm{ft}^{3} / \mathrm{s}\right)\end{array}$ & $\begin{array}{c}\text { Sus- } \\
\text { pended- } \\
\text { sediment } \\
\text { concen- } \\
\text { tration } \\
\text { (mg/L) }\end{array}$ \\
\hline \multirow[t]{45}{*}{ MYG } & 11410000 & $03 / 07 / 03$ & 1015 & 60 & 7 \\
\hline & 11410000 & 03/10/03 & 1115 & 58 & 2 \\
\hline & 11410000 & 03/10/03 & 1115 & 58 & 3 \\
\hline & 11410000 & $03 / 12 / 03$ & 0930 & 56 & 2 \\
\hline & 11410000 & $03 / 12 / 03$ & 0930 & 56 & 1 \\
\hline & 11410000 & 03/13/03 & 1430 & 56 & 3 \\
\hline & 11410000 & 03/13/03 & 1430 & 56 & 2 \\
\hline & 11410000 & 03/14/03 & 0700 & 66 & 4 \\
\hline & 11410000 & $03 / 14 / 03$ & 0700 & 66 & 4 \\
\hline & 11410000 & 03/14/03 & 0900 & 68 & 4 \\
\hline & 11410000 & $03 / 14 / 03$ & 0900 & 68 & 4 \\
\hline & 11410000 & $03 / 14 / 03$ & 1100 & 70 & 4 \\
\hline & 11410000 & $03 / 14 / 03$ & 1100 & 70 & 3 \\
\hline & 11410000 & $03 / 14 / 03$ & 1300 & 72 & 2 \\
\hline & 11410000 & 03/14/03 & 1300 & 72 & 5 \\
\hline & 11410000 & 03/14/03 & 1500 & 70 & 6 \\
\hline & 11410000 & $03 / 14 / 03$ & 1500 & 70 & 3 \\
\hline & 11410000 & $03 / 15 / 03$ & 0740 & 187 & 57 \\
\hline & 11410000 & $03 / 15 / 03$ & 0740 & 187 & 59 \\
\hline & 11410000 & 03/15/03 & 0930 & 675 & 180 \\
\hline & 11410000 & $03 / 15 / 03$ & 0930 & 675 & 178 \\
\hline & 11410000 & $03 / 15 / 03$ & 1130 & 1110 & 198 \\
\hline & 11410000 & $03 / 15 / 03$ & 1130 & 1110 & 224 \\
\hline & 11410000 & $03 / 15 / 03$ & 1330 & 1330 & 158 \\
\hline & 11410000 & $03 / 15 / 03$ & 1330 & 1330 & 157 \\
\hline & 11410000 & $03 / 15 / 03$ & 1530 & 1260 & 133 \\
\hline & 11410000 & 03/15/03 & 1530 & 1260 & 109 \\
\hline & 11410000 & 03/16/03 & 0730 & 236 & 10 \\
\hline & 11410000 & 03/16/03 & 0730 & 236 & 10 \\
\hline & 11410000 & 03/16/03 & 0930 & 183 & 9 \\
\hline & 11410000 & 03/16/03 & 0930 & 183 & 8 \\
\hline & 11410000 & $03 / 16 / 03$ & 1130 & 145 & 6 \\
\hline & 11410000 & 03/16/03 & 1130 & 145 & 7 \\
\hline & 11410000 & 03/16/03 & 1330 & 120 & 15 \\
\hline & 11410000 & 03/16/03 & 1330 & 120 & 5 \\
\hline & 11410000 & 03/16/03 & 1530 & 105 & 5 \\
\hline & 11410000 & 03/16/03 & 1530 & 105 & 5 \\
\hline & 11410000 & 03/17/03 & 1015 & 88 & 5 \\
\hline & 11410000 & 03/17/03 & 1015 & 88 & 4 \\
\hline & 11410000 & 03/19/03 & 1100 & 70 & 0.25 \\
\hline & 11410000 & 03/19/03 & 1100 & 70 & 1 \\
\hline & 11410000 & $03 / 21 / 03$ & 1100 & 70 & 2 \\
\hline & 11410000 & $03 / 21 / 03$ & 1100 & 70 & 1 \\
\hline & 11410000 & $03 / 24 / 03$ & 1110 & 70 & 2 \\
\hline & 11410000 & $03 / 24 / 03$ & 1110 & 70 & 1 \\
\hline
\end{tabular}

Table A1a. Suspended-sediment concentration samples and associated instantaneous streamflow for the Middle Yuba River near North San Juan (MYG) collected during water years 2001, 2002, and 2003.

[USGS Marina sediment laboratory uses $0.5 \mathrm{mg} / \mathrm{L}$ (milligram per liter) as the detection limit for reporting suspended-sediment concentration (SSC); therefore, samples with SSC of less than 0.5 $\mathrm{mg} / \mathrm{L}$ are reported as $0.25 \mathrm{mg} / \mathrm{L}$ (Helsel and Hirsch, 1992). $\mathrm{ft}^{3} / \mathrm{s}$, cubic feet per second]

\begin{tabular}{|c|c|c|c|c|c|}
\hline $\begin{array}{c}\text { Map } \\
\text { identifier }\end{array}$ & $\begin{array}{l}\text { Station } \\
\text { identifier }\end{array}$ & Date & Time & $\begin{array}{c}\text { Instan- } \\
\text { taneous } \\
\text { stream- } \\
\text { flow } \\
\left(\mathrm{ft}^{3} / \mathrm{s}\right)\end{array}$ & $\begin{array}{c}\text { Sus- } \\
\text { pended- } \\
\text { sediment } \\
\text { concen- } \\
\text { tration } \\
\text { (mg/L) }\end{array}$ \\
\hline \multirow[t]{45}{*}{ MYG } & 11410000 & $03 / 26 / 03$ & 1105 & 84 & 3 \\
\hline & 11410000 & $03 / 26 / 03$ & 1105 & 84 & 2 \\
\hline & 11410000 & $03 / 28 / 03$ & 1110 & 72 & 2 \\
\hline & 11410000 & $03 / 28 / 03$ & 1110 & 72 & 2 \\
\hline & 11410000 & $03 / 31 / 03$ & 0915 & 65 & 4 \\
\hline & 11410000 & $03 / 31 / 03$ & 0915 & 65 & 4 \\
\hline & 11410000 & 04/03/03 & 1030 & 63 & 2 \\
\hline & 11410000 & $04 / 03 / 03$ & 1030 & 63 & 1 \\
\hline & 11410000 & $04 / 04 / 03$ & 1400 & 74 & 1 \\
\hline & 11410000 & $04 / 04 / 03$ & 1400 & 74 & 1 \\
\hline & 11410000 & 04/09/03 & 1045 & 60 & 3 \\
\hline & 11410000 & 04/09/03 & 1045 & 60 & 2 \\
\hline & 11410000 & $04 / 11 / 03$ & 1120 & 60 & 1 \\
\hline & 11410000 & $04 / 11 / 03$ & 1120 & 60 & 2 \\
\hline & 11410000 & $04 / 14 / 03$ & 1040 & 190 & 8 \\
\hline & 11410000 & $04 / 14 / 03$ & 1040 & 190 & 8 \\
\hline & 11410000 & $04 / 16 / 03$ & 1100 & 118 & 3 \\
\hline & 11410000 & $04 / 16 / 03$ & 1100 & 118 & 2 \\
\hline & 11410000 & $04 / 18 / 03$ & 1025 & 110 & 4 \\
\hline & 11410000 & $04 / 18 / 03$ & 1025 & 110 & 2 \\
\hline & 11410000 & $04 / 21 / 03$ & 1055 & 105 & 5 \\
\hline & 11410000 & $04 / 21 / 03$ & 1055 & 105 & 0.25 \\
\hline & 11410000 & $04 / 23 / 03$ & 1040 & 90 & 3 \\
\hline & 11410000 & $04 / 23 / 03$ & 1040 & 90 & 2 \\
\hline & 11410000 & $04 / 28 / 03$ & 1050 & 200 & 56 \\
\hline & 11410000 & $04 / 28 / 03$ & 1050 & 200 & 54 \\
\hline & 11410000 & $04 / 30 / 03$ & 1035 & 155 & 3 \\
\hline & 11410000 & $04 / 30 / 03$ & 1035 & 155 & 3 \\
\hline & 11410000 & $05 / 02 / 03$ & 1010 & 127 & 1 \\
\hline & 11410000 & $05 / 02 / 03$ & 1010 & 127 & 4 \\
\hline & 11410000 & $05 / 05 / 03$ & 1050 & 511 & 5 \\
\hline & 11410000 & $05 / 05 / 03$ & 1050 & 511 & 6 \\
\hline & 11410000 & 05/06/03 & 1010 & 326 & 4 \\
\hline & 11410000 & 05/06/03 & 1010 & 326 & 4 \\
\hline & 11410000 & 05/07/03 & 1050 & 147 & 3 \\
\hline & 11410000 & 05/07/03 & 1050 & 147 & 6 \\
\hline & 11410000 & 05/08/03 & 1035 & 180 & 6 \\
\hline & 11410000 & 05/08/03 & 1035 & 180 & 4 \\
\hline & 11410000 & $05 / 09 / 03$ & 1005 & 173 & 3 \\
\hline & 11410000 & $05 / 09 / 03$ & 1005 & 173 & 4 \\
\hline & 11410000 & $05 / 14 / 03$ & 1105 & 120 & 1 \\
\hline & 11410000 & $05 / 14 / 03$ & 1105 & 120 & 2 \\
\hline & 11410000 & $05 / 16 / 03$ & 1010 & 155 & 1 \\
\hline & 11410000 & $05 / 16 / 03$ & 1010 & 155 & 4 \\
\hline & 11410000 & $05 / 19 / 03$ & 1055 & 100 & 1 \\
\hline
\end{tabular}


Table A1a. Suspended-sediment concentration samples and associated instantaneous streamflow for the Middle Yuba River near North San Juan (MYG) collected during water years 2001, 2002, and 2003.

[USGS Marina sediment laboratory uses $0.5 \mathrm{mg} / \mathrm{L}$ (milligram per liter) as the detection limit for reporting suspended-sediment concentration (SSC); therefore, samples with SSC of less than 0.5 $\mathrm{mg} / \mathrm{L}$ are reported as $0.25 \mathrm{mg} / \mathrm{L}$ (Helsel and Hirsch, 1992). $\mathrm{ft}^{3} / \mathrm{s}$, cubic feet per second]

\begin{tabular}{cccccc}
\hline $\begin{array}{c}\text { Map } \\
\text { identifier }\end{array}$ & $\begin{array}{c}\text { Station } \\
\text { identifier }\end{array}$ & Date & Time & $\begin{array}{c}\text { Instan- } \\
\text { taneous } \\
\text { stream- } \\
\text { flow } \\
\left(\mathrm{ft}^{3} / \mathrm{s}\right)\end{array}$ & $\begin{array}{c}\text { Sus- } \\
\text { pended- } \\
\text { sediment } \\
\text { concen- } \\
\text { tration } \\
(\mathrm{mg} / \mathrm{L})\end{array}$ \\
\hline MYG & 11410000 & $05 / 19 / 03$ & 1055 & 100 & 2 \\
& 11410000 & $05 / 21 / 03$ & 1110 & 97 & 1 \\
& 11410000 & $05 / 21 / 03$ & 1110 & 97 & 2 \\
& 11410000 & $05 / 22 / 03$ & 1040 & 97 & 1 \\
& 11410000 & $05 / 22 / 03$ & 1040 & 97 & 2 \\
& 11410000 & $05 / 23 / 03$ & 1115 & 95 & 4 \\
& 11410000 & $05 / 23 / 03$ & 1115 & 95 & 1 \\
11410000 & $05 / 27 / 03$ & 1030 & 88 & 1 \\
11410000 & $05 / 27 / 03$ & 1030 & 88 & 1 \\
11410000 & $05 / 29 / 03$ & 1025 & 259 & 6 \\
11410000 & $05 / 29 / 03$ & 1025 & 259 & 8 \\
\hline
\end{tabular}


Table A1b. Suspended-sediment concentration samples and associated instantaneous streamflow for the South Yuba River at Jones Bar near Grass Valley (SYG) collected during water years 2001, 2002, and 2003.

[USGS Marina sediment laboratory uses $0.5 \mathrm{mg} / \mathrm{L}$ (milligram per liter) as the detection limit for reporting suspended-sediment concentration (SSC); therefore, samples with SSC of less than $0.5 \mathrm{mg} / \mathrm{L}$ are reported as $0.25 \mathrm{mg} / \mathrm{L}$ (Helsel and Hirsch, 1992). $\mathrm{ft}^{3} / \mathrm{s}$, cubic feet per second]

\begin{tabular}{|c|c|c|c|c|c|}
\hline $\begin{array}{l}\text { Map } \\
\text { iden- } \\
\text { tifier }\end{array}$ & $\begin{array}{l}\text { Station } \\
\text { identifier }\end{array}$ & Date & Time & $\begin{array}{c}\text { Instan- } \\
\text { taneous } \\
\text { streamflow } \\
\left(\mathrm{ft}^{3} / \mathrm{s}\right) \\
\end{array}$ & $\begin{array}{l}\text { Suspended- } \\
\text { sediment } \\
\text { concentration } \\
(\mathrm{mg} / \mathrm{L})\end{array}$ \\
\hline \multirow[t]{47}{*}{$\overline{\text { SYG }}$} & 11417500 & $11 / 07 / 00$ & 1235 & 66 & 0.25 \\
\hline & 11417500 & $11 / 08 / 00$ & 1220 & 65 & 0.25 \\
\hline & 11417500 & $11 / 09 / 00$ & 1205 & 63 & 1 \\
\hline & 11417500 & $11 / 13 / 00$ & 1145 & 59 & 1 \\
\hline & 11417500 & $11 / 14 / 00$ & 1115 & 67 & 0.25 \\
\hline & 11417500 & $11 / 15 / 00$ & 1050 & 70 & 0.25 \\
\hline & 11417500 & $11 / 16 / 00$ & 1055 & 63 & 0.25 \\
\hline & 11417500 & $11 / 17 / 00$ & 1445 & 62 & 0.25 \\
\hline & 11417500 & $11 / 20 / 00$ & 1015 & 61 & 0.25 \\
\hline & 11417500 & $11 / 21 / 00$ & 1015 & 61 & 0.25 \\
\hline & 11417500 & $11 / 22 / 00$ & 0910 & 61 & 1 \\
\hline & 11417500 & $11 / 24 / 00$ & 0910 & 61 & 1 \\
\hline & 11417500 & $11 / 27 / 00$ & 0930 & 61 & 2 \\
\hline & 11417500 & $11 / 28 / 00$ & 1000 & 61 & 0.25 \\
\hline & 11417500 & $11 / 29 / 00$ & 1000 & 73 & 2 \\
\hline & 11417500 & $11 / 30 / 00$ & 0945 & 144 & 9 \\
\hline & 11417500 & $12 / 04 / 00$ & 0940 & 67 & 1 \\
\hline & 11417500 & $12 / 05 / 00$ & 1000 & 65 & 0.25 \\
\hline & 11417500 & $12 / 06 / 00$ & 1045 & 63 & 1 \\
\hline & 11417500 & $12 / 06 / 00$ & 1045 & 63 & 2 \\
\hline & 11417500 & $12 / 07 / 00$ & 1040 & 63 & 1 \\
\hline & 11417500 & $12 / 07 / 00$ & 1310 & 65 & 2 \\
\hline & 11417500 & $12 / 08 / 00$ & 0930 & 63 & 1 \\
\hline & 11417500 & $12 / 09 / 00$ & 0945 & 63 & 1 \\
\hline & 11417500 & $12 / 12 / 00$ & 0935 & 119 & 2 \\
\hline & 11417500 & $12 / 13 / 00$ & 0945 & 102 & 5 \\
\hline & 11417500 & $12 / 13 / 00$ & 0945 & 102 & 4 \\
\hline & 11417500 & $12 / 14 / 00$ & 0930 & 158 & 7 \\
\hline & 11417500 & $12 / 15 / 00$ & 0920 & 262 & 28 \\
\hline & 11417500 & $12 / 18 / 00$ & 0945 & 107 & 2 \\
\hline & 11417500 & $12 / 19 / 00$ & 0930 & 95 & 2 \\
\hline & 11417500 & $12 / 20 / 00$ & 0920 & 89 & 2 \\
\hline & 11417500 & $12 / 20 / 00$ & 0920 & 89 & 2 \\
\hline & 11417500 & $12 / 21 / 00$ & 0920 & 84 & 4 \\
\hline & 11417500 & $12 / 22 / 00$ & 0930 & 89 & 1 \\
\hline & 11417500 & $12 / 26 / 00$ & 0930 & 74 & 0.25 \\
\hline & 11417500 & $12 / 27 / 00$ & 0930 & 73 & 3 \\
\hline & 11417500 & $12 / 27 / 00$ & 0930 & 73 & 2 \\
\hline & 11417500 & $12 / 28 / 00$ & 0910 & 71 & 4 \\
\hline & 11417500 & $12 / 29 / 00$ & 0920 & 70 & 0.25 \\
\hline & 11417500 & $01 / 02 / 01$ & 0920 & 67 & 1 \\
\hline & 11417500 & $01 / 03 / 01$ & 0925 & 66 & 3 \\
\hline & 11417500 & $01 / 03 / 01$ & 0925 & 66 & 1 \\
\hline & 11417500 & 01/04/01 & 0920 & 63 & 0.25 \\
\hline & 11417500 & $01 / 05 / 01$ & 1130 & 65 & 4 \\
\hline & 11417500 & $01 / 09 / 01$ & 0930 & 75 & 1 \\
\hline & 11417500 & 01/10/01 & 0940 & 81 & 1 \\
\hline
\end{tabular}

Table A1b. Suspended-sediment concentration samples and associated instantaneous streamflow for the South Yuba River at Jones Bar near Grass Valley (SYG) collected during water years 2001, 2002, and 2003.

[USGS Marina sediment laboratory uses $0.5 \mathrm{mg} / \mathrm{L}$ (milligram per liter) as the detection limit for reporting suspended-sediment concentration (SSC); therefore, samples with SSC of less than $0.5 \mathrm{mg} / \mathrm{L}$ are reported as $0.25 \mathrm{mg} / \mathrm{L}$ (Helsel and Hirsch, 1992). $\mathrm{ft}^{3} / \mathrm{s}$, cubic feet per second]

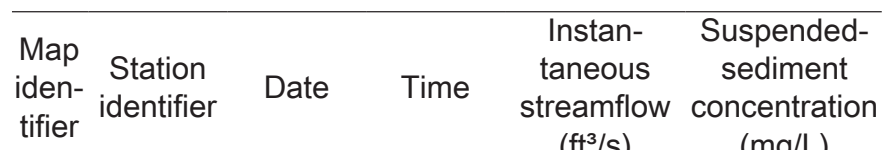

\begin{tabular}{rllcc}
\hline SYG 11417500 & $01 / 10 / 01$ & 0940 & 81 & $(\mathrm{mg} / \mathrm{L})$ \\
11417500 & $01 / 11 / 01$ & 1045 & 310 & 1 \\
11417500 & $01 / 11 / 01$ & 1201 & 307 & 34 \\
11417500 & $01 / 12 / 01$ & 0945 & 178 & 19
\end{tabular}

$\begin{array}{llll}11417500 & 01 / 16 / 01 & 0915 & 92\end{array}$

$\begin{array}{llll}11417500 & 01 / 17 / 01 & 0930 & 83\end{array}$

$\begin{array}{llll}11417500 & 01 / 17 / 01 & 0930 & 83\end{array}$

$11417500 \quad 01 / 18 / 01$

$11417500 \quad 01 / 19 / 01$

0930

$11417500 \quad 01 / 22 / 01$

$\begin{array}{ll}11417500 & 01 / 23 / 01\end{array}$

$11417500 \quad 01 / 24 / 01$

$11417500 \quad 01 / 24 / 01$

$11417500 \quad 01 / 25 / 01$

$11417500 \quad 01 / 26 / 01$

$11417500 \quad 01 / 29 / 01$

0930

1320

0935

0940

0940

0940

0930

0940

$11417500 \quad 01 / 30 / 01$

$11417500 \quad 01 / 31 / 01$

$11417500 \quad 01 / 31 / 01$

$11417500 \quad 02 / 01 / 01$

0920

0935

0935

0935

$11417500 \quad 02 / 02 / 01$

0925

$11417500 \quad 02 / 03 / 01$

0935

$11417500 \quad 02 / 05 / 01$

$11417500 \quad 02 / 06 / 01$

0940

$11417500 \quad 02 / 07 / 01$

1210

0925

$11417500 \quad 02 / 07 / 01$

0925

$11417500 \quad 02 / 08 / 01$

$11417500 \quad 02 / 09 / 01$

0925

0920

1030

11417500 02/10/01

0950

$11417500 \quad 02 / 12 / 01$

$11417500 \quad 02 / 13 / 01$

0920

0930

0920

0920

$11417500 \quad 02 / 15 / 01$

$11417500 \quad 02 / 16 / 01$

$11417500 \quad 02 / 20 / 01$

$11417500 \quad 02 / 22 / 01$

0925

0940

0925

0930

$11417500 \quad 02 / 23 / 01$

$11417500 \quad 02 / 26 / 01$

0940

0930

$11417500 \quad 02 / 27 / 01$

1030

1435

$11417500 \quad 02 / 27 / 01$

0935

$11417500 \quad 02 / 28 / 01$

$11417500 \quad 03 / 01 / 01$

0925

$11417500 \quad 03 / 05 / 01$

0940

1000

1015

$11417500 \quad 03 / 07 / 01$
83
79

80

77

77

163

163

141

158

114

122

103

103

99.5

92

97

124

125

121

$$
121
$$

103

$$
96
$$

169

205

180

162

127

127

127

445

731

478

335

285

282

277

250

223

1290

676

514
1
1

1

1

0.25

1

2

10

10

$$
12
$$$$
6
$$$$
11
$$$$
4
$$$$
8
$$$$
8
$$$$
2
$$$$
1
$$$$
6
$$$$
3
$$$$
3
$$$$
2
$$$$
7
$$$$
2
$$$$
2
$$$$
18
$$$$
6
$$$$
4
$$$$
2
$$$$
1
$$$$
2
$$$$
3
$$$$
76
$$$$
84
$$$$
26
$$$$
6
$$$$
4
$$$$
17
$$$$
3
$$$$
3
$$$$
\begin{aligned}
& 3 \\
& 3
\end{aligned}
$$$$
168
$$$$
17
$$ 
Table A1b. Suspended-sediment concentration samples and associated instantaneous streamflow for the South Yuba River at Jones Bar near Grass Valley (SYG) collected during water years 2001, 2002, and 2003.

[USGS Marina sediment laboratory uses $0.5 \mathrm{mg} / \mathrm{L}$ (milligram per liter) as the detection limit for reporting suspended-sediment concentration (SSC); therefore, samples with SSC of less than $0.5 \mathrm{mg} / \mathrm{L}$ are reported as $0.25 \mathrm{mg} / \mathrm{L}$ (Helsel and Hirsch, 1992). $\mathrm{ft}^{3} / \mathrm{s}$, cubic feet per second]

\begin{tabular}{|c|c|c|c|c|c|}
\hline $\begin{array}{l}\text { Map } \\
\text { iden- } \\
\text { tifier }\end{array}$ & $\begin{array}{l}\text { Station } \\
\text { identifier }\end{array}$ & Date & Time & $\begin{array}{c}\text { Instan- } \\
\text { taneous } \\
\text { streamflow } \\
\left(\mathrm{ft}^{3} / \mathrm{s}\right)\end{array}$ & $\begin{array}{l}\text { Suspended- } \\
\text { sediment } \\
\text { concentration } \\
(\mathrm{mg} / \mathrm{L})\end{array}$ \\
\hline \multirow[t]{47}{*}{ SYG } & 11417500 & 03/08/01 & 1005 & 478 & 5 \\
\hline & 11417500 & 03/09/01 & 0945 & 423 & 5 \\
\hline & 11417500 & 03/09/01 & 0945 & 423 & 5 \\
\hline & 11417500 & 03/12/01 & 0945 & 275 & 3 \\
\hline & 11417500 & 03/13/01 & 0945 & 259 & 2 \\
\hline & 11417500 & 03/14/01 & 1000 & 259 & 2 \\
\hline & 11417500 & 03/14/01 & 1000 & 259 & 2 \\
\hline & 11417500 & 03/15/01 & 0950 & 255 & 1 \\
\hline & 11417500 & 03/16/01 & 0950 & 241 & 1 \\
\hline & 11417500 & 03/20/01 & 0945 & 312 & 2 \\
\hline & 11417500 & 03/21/01 & 0940 & 335 & 3 \\
\hline & 11417500 & $03 / 21 / 01$ & 0940 & 335 & 3 \\
\hline & 11417500 & $03 / 22 / 01$ & 0920 & 318 & 6 \\
\hline & 11417500 & $03 / 23 / 01$ & 1100 & 307 & 5 \\
\hline & 11417500 & 03/27/01 & 1225 & 337 & 2 \\
\hline & 11417500 & 03/28/01 & 0950 & 307 & 2 \\
\hline & 11417500 & 03/29/01 & 0945 & 318 & 1 \\
\hline & 11417500 & 03/30/01 & 0950 & 292 & 3 \\
\hline & 11417500 & 03/30/01 & 0955 & 292 & 1 \\
\hline & 11417500 & $04 / 02 / 01$ & 0940 & 254 & 1 \\
\hline & 11417500 & 04/03/01 & 0945 & 230 & 1 \\
\hline & 11417500 & 04/04/01 & 0945 & 211 & 1 \\
\hline & 11417500 & 04/04/01 & 0950 & 211 & 1 \\
\hline & 11417500 & $04 / 05 / 01$ & 0955 & 190 & 1 \\
\hline & 11417500 & 04/06/01 & 0945 & 182 & 1 \\
\hline & 11417500 & $04 / 09 / 01$ & 0950 & 198 & 2 \\
\hline & 11417500 & 04/10/01 & 0945 & 191 & 1 \\
\hline & 11417500 & $04 / 11 / 01$ & 0955 & 187 & 2 \\
\hline & 11417500 & $04 / 12 / 01$ & 0915 & 252 & 10 \\
\hline & 11417500 & 04/13/01 & 0935 & 205 & 3 \\
\hline & 11417500 & $04 / 16 / 01$ & 0930 & 196 & 1 \\
\hline & 11417500 & 04/17/01 & 0950 & 205 & 1 \\
\hline & 11417500 & $04 / 18 / 01$ & 1000 & 214 & 1 \\
\hline & 11417500 & 04/19/01 & 0945 & 250 & 0.25 \\
\hline & 11417500 & 04/20/01 & 1000 & 342 & 8 \\
\hline & 11417500 & $04 / 23 / 01$ & 0950 & 301 & 2 \\
\hline & 11417500 & $04 / 24 / 01$ & 0955 & 305 & 2 \\
\hline & 11417500 & $04 / 24 / 01$ & 0955 & 305 & 2 \\
\hline & 11417500 & $04 / 25 / 01$ & 0945 & 301 & 2 \\
\hline & 11417500 & $04 / 26 / 01$ & 0950 & 314 & 3 \\
\hline & 11417500 & $04 / 26 / 01$ & 0950 & 314 & 2 \\
\hline & 11417500 & 04/30/01 & 0940 & 239 & 3 \\
\hline & 11417500 & 05/01/01 & 0945 & 249 & 5 \\
\hline & 11417500 & $05 / 02 / 01$ & 0945 & 243 & 3 \\
\hline & 11417500 & 05/03/01 & 0945 & 212 & 3 \\
\hline & 11417500 & 05/04/01 & 0940 & 198 & 4 \\
\hline & 11417500 & 05/07/01 & 0955 & 189 & 2 \\
\hline
\end{tabular}

Table A1b. Suspended-sediment concentration samples and associated instantaneous streamflow for the South Yuba River at Jones Bar near Grass Valley (SYG) collected during water years 2001, 2002, and 2003.

[USGS Marina sediment laboratory uses $0.5 \mathrm{mg} / \mathrm{L}$ (milligram per liter) as the detection limit for reporting suspended-sediment concentration (SSC); therefore, samples with SSC of less than $0.5 \mathrm{mg} / \mathrm{L}$ are reported as $0.25 \mathrm{mg} / \mathrm{L}$ (Helsel and Hirsch, 1992). $\mathrm{ft}^{3} / \mathrm{s}$, cubic feet per second]

\begin{tabular}{cccc}
\hline Map Station & & Instan- & Suspended- \\
iden- & Daneous & Time & sediment
\end{tabular}

iden-
tifier

\begin{tabular}{rrrcc}
\hline SYG 11417500 & $05 / 08 / 01$ & 0950 & 187 & $(\mathrm{mg} / \mathrm{L})$ \\
11417500 & $05 / 09 / 01$ & 0935 & 189 & 4 \\
11417500 & $05 / 10 / 01$ & 0930 & 177 & 4
\end{tabular}

$\begin{array}{lllll}11417500 & 05 / 11 / 01 & 0930 & 168 & 2\end{array}$

$\begin{array}{lllll}11417500 & 05 / 14 / 01 & 0930 & 145 & 1\end{array}$

$\begin{array}{lllll}11417500 & 05 / 15 / 01 & 1000 & 140 & 1\end{array}$

$\begin{array}{lllll}11417500 & 05 / 16 / 01 & 0950 & 150 & 2\end{array}$

$\begin{array}{lllll}11417500 & 05 / 17 / 01 & 0945 & 139 & 1\end{array}$

$\begin{array}{lllll}11417500 & 05 / 18 / 01 & 0930 & 128 & 1\end{array}$

$\begin{array}{lllll}11417500 & 05 / 21 / 01 & 0930 & 102 & 2\end{array}$

$\begin{array}{lllll}11417500 & 05 / 22 / 01 & 0925 & 92 & 3\end{array}$

$\begin{array}{lllll}11417500 & 05 / 23 / 01 & 0945 & 92 & 3\end{array}$

$\begin{array}{lllll}11417500 & 05 / 24 / 01 & 0945 & 85 & 1\end{array}$

$\begin{array}{lllll}11417500 & 04 / 05 / 01 & 0935 & 82 & 3\end{array}$

$\begin{array}{lllll}11417500 & 04 / 09 / 01 & 0945 & 71 & 3\end{array}$

$\begin{array}{lllll}11417500 & 05 / 30 / 01 & 0940 & 69 & 3\end{array}$

$\begin{array}{lllll}11417500 & 05 / 31 / 01 & 0950 & 64 & 2\end{array}$

$\begin{array}{lllll}11417500 & 06 / 01 / 01 & 0940 & 62 & 4\end{array}$

$\begin{array}{lllll}11417500 & 06 / 04 / 01 & 0930 & 64 & 2\end{array}$

$\begin{array}{lllll}11417500 & 06 / 05 / 01 & 0935 & 59 & 2\end{array}$

$\begin{array}{lllll}11417500 & 06 / 06 / 01 & 0945 & 58 & 2\end{array}$

$\begin{array}{lllll}11417500 & 06 / 07 / 01 & 0940 & 59 & 1\end{array}$

$\begin{array}{lllll}11417500 & 06 / 08 / 01 & 0935 & 55 & 0.25\end{array}$

$11417500 \quad 06 / 11 / 01 \quad 0950 \quad 51 \quad 1$

$\begin{array}{lllll}11417500 & 06 / 12 / 01 & 1000 & 49 & 2\end{array}$

$\begin{array}{lllll}11417500 & 06 / 13 / 01 & 0955 & 52 & 0.25\end{array}$

$\begin{array}{lllll}11417500 & 06 / 14 / 01 & 0950 & 48 & 1\end{array}$

$\begin{array}{lllll}11417500 & 06 / 15 / 01 & 0930 & 49 & 3\end{array}$

$\begin{array}{lllll}11417500 & 06 / 18 / 01 & 0955 & 46 & 3\end{array}$

$\begin{array}{lllll}11417500 & 06 / 19 / 01 & 0950 & 46 & 1\end{array}$

$\begin{array}{lllll}11417500 & 06 / 20 / 01 & 0940 & 46 & 1\end{array}$

$\begin{array}{lllll}11417500 & 06 / 21 / 01 & 0930 & 47 & 1\end{array}$

$\begin{array}{lllll}11417500 & 06 / 22 / 01 & 0915 & 46 & 2\end{array}$

$\begin{array}{lllll}11417500 & 06 / 25 / 01 & 0945 & 43 & 3\end{array}$

$\begin{array}{lllll}11417500 & 06 / 26 / 01 & 0930 & 47 & 2\end{array}$

$\begin{array}{lllll}11417500 & 06 / 27 / 01 & 0930 & 51 & 1\end{array}$

$\begin{array}{lllll}11417500 & 06 / 28 / 01 & 0930 & 55 & 2\end{array}$

$\begin{array}{lllll}11417500 & 06 / 29 / 01 & 0950 & 52 & 1\end{array}$

$\begin{array}{lllll}11417500 & 07 / 02 / 01 & 0935 & 43 & 2\end{array}$

$\begin{array}{lllll}11417500 & 07 / 06 / 01 & 0930 & 38 & 2\end{array}$

$\begin{array}{lllll}11417500 & 07 / 09 / 01 & 0930 & 46 & 3\end{array}$

$\begin{array}{lllll}11417500 & 07 / 10 / 01 & 0940 & 44 & 1\end{array}$

$\begin{array}{lllll}11417500 & 07 / 11 / 01 & 0930 & 42 & 1\end{array}$

$\begin{array}{lllll}11417500 & 07 / 12 / 01 & 0915 & 41 & 1\end{array}$

$\begin{array}{lllll}11417500 & 07 / 16 / 01 & 0940 & 43 & 1\end{array}$

$\begin{array}{lllll}11417500 & 07 / 17 / 01 & 0950 & 40 & 3\end{array}$

$\begin{array}{lllll}11417500 & 07 / 18 / 01 & 0935 & 38 & 1\end{array}$ 
Table A1b. Suspended-sediment concentration samples and associated instantaneous streamflow for the South Yuba River at Jones Bar near Grass Valley (SYG) collected during water years 2001, 2002, and 2003.

[USGS Marina sediment laboratory uses $0.5 \mathrm{mg} / \mathrm{L}$ (milligram per liter) as the detection limit for reporting suspended-sediment concentration (SSC); therefore, samples with SSC of less than $0.5 \mathrm{mg} / \mathrm{L}$ are reported as $0.25 \mathrm{mg} / \mathrm{L}$ (Helsel and Hirsch, 1992). $\mathrm{ft}^{3} / \mathrm{s}$, cubic feet per second]

\begin{tabular}{|c|c|c|c|c|c|}
\hline $\begin{array}{l}\text { Map } \\
\text { iden- } \\
\text { tifier }\end{array}$ & $\begin{array}{l}\text { Station } \\
\text { identifier }\end{array}$ & Date & Time & $\begin{array}{c}\text { Instan- } \\
\text { taneous } \\
\text { streamflow } \\
\left(\mathrm{ft}^{3} / \mathrm{s}\right) \\
\end{array}$ & $\begin{array}{l}\text { Suspended- } \\
\text { sediment } \\
\text { concentration } \\
(\mathrm{mg} / \mathrm{L})\end{array}$ \\
\hline \multirow[t]{47}{*}{$\overline{\mathrm{SYG}}$} & 11417500 & $07 / 19 / 01$ & 0950 & 38 & 1 \\
\hline & 11417500 & 07/20/01 & 0930 & 35 & 5 \\
\hline & 11417500 & 07/21/01 & 1230 & 35 & 5 \\
\hline & 11417500 & $07 / 23 / 01$ & 1030 & 33 & 2 \\
\hline & 11417500 & $07 / 24 / 01$ & 1000 & 35 & 2 \\
\hline & 11417500 & $07 / 25 / 01$ & 0930 & 35 & 1 \\
\hline & 11417500 & $07 / 26 / 01$ & 0930 & 34 & 1 \\
\hline & 11417500 & 07/27/01 & 0930 & 33 & 0.25 \\
\hline & 11417500 & $07 / 30 / 01$ & 0955 & 32 & 2 \\
\hline & 11417500 & $07 / 31 / 01$ & 0930 & 33 & 2 \\
\hline & 11417500 & 08/01/01 & 0945 & 34 & 2 \\
\hline & 11417500 & 08/03/01 & 0805 & 33 & 1 \\
\hline & 11417500 & 08/06/01 & 1015 & 33 & 1 \\
\hline & 11417500 & 08/07/01 & 0855 & 33 & 1 \\
\hline & 11417500 & 08/15/01 & 0915 & 32 & 1 \\
\hline & 11417500 & $08 / 21 / 01$ & 0900 & 32 & 0.25 \\
\hline & 11417500 & 08/29/01 & 0935 & 32 & 2 \\
\hline & 11417500 & 09/05/01 & 0905 & 32 & 1 \\
\hline & 11417500 & 09/05/01 & 0905 & 31 & 2 \\
\hline & 11417500 & 09/11/01 & 0825 & 32 & 2 \\
\hline & 11417500 & 09/21/01 & 0955 & 33 & 2 \\
\hline & 11417500 & 09/27/01 & 1000 & 36 & 2 \\
\hline & 11417500 & 09/30/01 & 2330 & 35 & 1 \\
\hline & 11417500 & $10 / 03 / 01$ & 1015 & 34 & 1 \\
\hline & 11417500 & $10 / 10 / 01$ & 1000 & 31 & 1 \\
\hline & 11417500 & $10 / 24 / 01$ & 1010 & 31 & 1 \\
\hline & 11417500 & $10 / 30 / 01$ & 1000 & 42 & 2 \\
\hline & 11417500 & $10 / 31 / 01$ & 0935 & 86 & 4 \\
\hline & 11417500 & $11 / 01 / 01$ & 1305 & 53 & 3 \\
\hline & 11417500 & $11 / 02 / 01$ & 1015 & 42 & 2 \\
\hline & 11417500 & $11 / 07 / 01$ & 0955 & 36 & 1 \\
\hline & 11417500 & 11/13/01 & 1310 & 178 & 38 \\
\hline & 11417500 & $11 / 14 / 01$ & 0805 & 89 & 7 \\
\hline & 11417500 & $11 / 26 / 01$ & 0945 & 167 & 8 \\
\hline & 11417500 & $11 / 27 / 01$ & 1230 & 106 & 2 \\
\hline & 11417500 & $11 / 28 / 01$ & 1000 & 87 & 3 \\
\hline & 11417500 & $11 / 29 / 01$ & 0925 & 128 & 3 \\
\hline & 11417500 & $11 / 30 / 01$ & 1000 & 156 & 8 \\
\hline & 11417500 & $12 / 03 / 01$ & 0945 & 890 & 28 \\
\hline & 11417500 & $12 / 04 / 01$ & 1225 & 369 & 11 \\
\hline & 11417500 & $12 / 05 / 01$ & 0930 & 275 & 4 \\
\hline & 11417500 & $12 / 06 / 01$ & 1200 & 428 & 13 \\
\hline & 11417500 & $12 / 07 / 01$ & 1215 & 392 & 5 \\
\hline & 11417500 & $12 / 11 / 01$ & 1200 & 171 & 2 \\
\hline & 11417500 & $12 / 12 / 01$ & 0945 & 148 & 2 \\
\hline & 11417500 & $12 / 13 / 01$ & 0930 & 132 & 1 \\
\hline & 11417500 & $12 / 14 / 01$ & 0930 & 394 & 15 \\
\hline
\end{tabular}

Table A1b. Suspended-sediment concentration samples and associated instantaneous streamflow for the South Yuba River at Jones Bar near Grass Valley (SYG) collected during water years 2001, 2002, and 2003.

[USGS Marina sediment laboratory uses $0.5 \mathrm{mg} / \mathrm{L}$ (milligram per liter) as the detection limit for reporting suspended-sediment concentration (SSC); therefore, samples with SSC of less than $0.5 \mathrm{mg} / \mathrm{L}$ are reported as $0.25 \mathrm{mg} / \mathrm{L}$ (Helsel and Hirsch, 1992). $\mathrm{ft}^{3} / \mathrm{s}$, cubic feet per second]

\begin{tabular}{|c|c|c|c|c|c|}
\hline $\begin{array}{l}\text { Map } \\
\text { iden- } \\
\text { tifier }\end{array}$ & $\begin{array}{l}\text { Station } \\
\text { identifier }\end{array}$ & Date & Time & $\begin{array}{c}\text { Instan- } \\
\text { taneous } \\
\text { streamflow } \\
\left(\mathrm{ft}^{3} / \mathrm{s}\right)\end{array}$ & $\begin{array}{l}\text { Suspended- } \\
\text { sediment } \\
\text { concentration } \\
(\mathrm{mg} / \mathrm{L})\end{array}$ \\
\hline \multirow[t]{47}{*}{$\overline{\text { SYG }}$} & 11417500 & $12 / 15 / 01$ & 0905 & 257 & 10 \\
\hline & 11417500 & $12 / 18 / 01$ & 0935 & 593 & 15 \\
\hline & 11417500 & $12 / 19 / 01$ & 1230 & 337 & 3 \\
\hline & 11417500 & $12 / 20 / 01$ & 0930 & 415 & 8 \\
\hline & 11417500 & $12 / 21 / 01$ & 1135 & 439 & 19 \\
\hline & 11417500 & $12 / 26 / 01$ & 0920 & 259 & 4 \\
\hline & 11417500 & $12 / 27 / 01$ & 1220 & 262 & 1 \\
\hline & 11417500 & $12 / 28 / 01$ & 0915 & 294 & 2 \\
\hline & 11417500 & $12 / 29 / 01$ & 0840 & 709 & 29 \\
\hline & 11417500 & $12 / 31 / 01$ & 0910 & 1770 & 97 \\
\hline & 11417500 & $12 / 31 / 01$ & 1300 & 1580 & 51 \\
\hline & 11417500 & $12 / 31 / 01$ & 1400 & 1510 & 40 \\
\hline & 11417500 & $12 / 31 / 01$ & 1500 & 1450 & 35 \\
\hline & 11417500 & $12 / 31 / 01$ & 1600 & 1400 & 32 \\
\hline & 11417500 & 01/03/02 & 1225 & 1300 & 14 \\
\hline & 11417500 & 01/04/02 & 0910 & 794 & 8 \\
\hline & 11417500 & 01/08/02 & 0915 & 665 & 5 \\
\hline & 11417500 & 01/09/02 & 0915 & 552 & 5 \\
\hline & 11417500 & 01/09/02 & 0915 & 552 & 4 \\
\hline & 11417500 & 01/10/02 & 1220 & 460 & 2 \\
\hline & 11417500 & $01 / 11 / 02$ & 0940 & 406 & 6 \\
\hline & 11417500 & $01 / 14 / 02$ & 0920 & 307 & 2 \\
\hline & 11417500 & $01 / 14 / 02$ & 0920 & 307 & 3 \\
\hline & 11417500 & 01/15/02 & 0930 & 285 & 1 \\
\hline & 11417500 & 01/16/02 & 0945 & 262 & 2 \\
\hline & 11417500 & $01 / 17 / 02$ & 0940 & 246 & 2 \\
\hline & 11417500 & 01/17/02 & 0940 & 246 & 1 \\
\hline & 11417500 & 01/18/02 & 1210 & 227 & 1 \\
\hline & 11417500 & $01 / 22 / 02$ & 0950 & 227 & 1 \\
\hline & 11417500 & $01 / 23 / 02$ & 0920 & 189 & 1 \\
\hline & 11417500 & $01 / 23 / 02$ & 0920 & 189 & 2 \\
\hline & 11417500 & $01 / 24 / 02$ & 0930 & 189 & 1 \\
\hline & 11417500 & $01 / 25 / 02$ & 0930 & 181 & 2 \\
\hline & 11417500 & $01 / 28 / 02$ & 0920 & 267 & 5 \\
\hline & 11417500 & $01 / 28 / 02$ & 0920 & 267 & 3 \\
\hline & 11417500 & $01 / 29 / 02$ & 0930 & 233 & 3 \\
\hline & 11417500 & 01/30/02 & 0935 & 215 & 2 \\
\hline & 11417500 & $01 / 31 / 02$ & 0940 & 208 & 3 \\
\hline & 11417500 & $01 / 31 / 02$ & 0940 & 208 & 2 \\
\hline & 11417500 & 02/04/02 & 0935 & 169 & 1 \\
\hline & 11417500 & $02 / 11 / 02$ & 1020 & 233 & 2 \\
\hline & 11417500 & $02 / 12 / 02$ & 0920 & 226 & 2 \\
\hline & 11417500 & 02/13/02 & 0940 & 224 & 1 \\
\hline & 11417500 & 02/13/02 & 0940 & 224 & 2 \\
\hline & 11417500 & $02 / 14 / 02$ & 1045 & 233 & 2 \\
\hline & 11417500 & $02 / 15 / 02$ & 1030 & 229 & 1 \\
\hline & 11417500 & 02/19/02 & 0920 & 285 & 5 \\
\hline
\end{tabular}


Table A1b. Suspended-sediment concentration samples and associated instantaneous streamflow for the South Yuba River at Jones Bar near Grass Valley (SYG) collected during water years 2001, 2002, and 2003.

[USGS Marina sediment laboratory uses $0.5 \mathrm{mg} / \mathrm{L}$ (milligram per liter) as the detection limit for reporting suspended-sediment concentration (SSC); therefore, samples with SSC of less than $0.5 \mathrm{mg} / \mathrm{L}$ are reported as $0.25 \mathrm{mg} / \mathrm{L}$ (Helsel and Hirsch, 1992). $\mathrm{ft}^{3} / \mathrm{s}$, cubic feet per second]

\begin{tabular}{|c|c|c|c|c|c|}
\hline $\begin{array}{l}\text { Map } \\
\text { iden- } \\
\text { tifier }\end{array}$ & $\begin{array}{l}\text { Station } \\
\text { identifier }\end{array}$ & Date & Time & $\begin{array}{c}\text { Instan- } \\
\text { taneous } \\
\text { streamflow } \\
\left(\mathrm{ft}^{3} / \mathrm{s}\right)\end{array}$ & $\begin{array}{l}\text { Suspended- } \\
\text { sediment } \\
\text { concentration } \\
(\mathrm{mg} / \mathrm{L})\end{array}$ \\
\hline \multirow[t]{47}{*}{ SYG } & 11417500 & $02 / 19 / 02$ & 0920 & 285 & 7 \\
\hline & 11417500 & $02 / 20 / 02$ & 0915 & 2000 & 213 \\
\hline & 11417500 & $02 / 21 / 02$ & 0920 & 1070 & 15 \\
\hline & 11417500 & $02 / 22 / 02$ & 0920 & 739 & 6 \\
\hline & 11417500 & $02 / 22 / 02$ & 0920 & 739 & 6 \\
\hline & 11417500 & $02 / 25 / 02$ & 0920 & 454 & 3 \\
\hline & 11417500 & $02 / 26 / 02$ & 0915 & 411 & 2 \\
\hline & 11417500 & $02 / 27 / 02$ & 0925 & 385 & 1 \\
\hline & 11417500 & $02 / 28 / 02$ & 0930 & 365 & 1 \\
\hline & 11417500 & $02 / 28 / 02$ & 0930 & 365 & 0.25 \\
\hline & 11417500 & 03/01/02 & 0920 & 338 & 2 \\
\hline & 11417500 & 03/04/02 & 0910 & 277 & 0.25 \\
\hline & 11417500 & 03/05/02 & 0900 & 267 & 0.25 \\
\hline & 11417500 & 03/06/02 & 1230 & 606 & 44 \\
\hline & 11417500 & 03/06/02 & 1255 & 603 & 28 \\
\hline & 11417500 & 03/06/02 & 1255 & 603 & 30 \\
\hline & 11417500 & 03/07/02 & 0910 & 1280 & 50 \\
\hline & 11417500 & 03/07/02 & 1200 & 1250 & 35 \\
\hline & 11417500 & 03/08/02 & 0905 & 1070 & 23 \\
\hline & 11417500 & 03/08/02 & 0905 & 1070 & 50 \\
\hline & 11417500 & 03/08/02 & 1215 & 998 & 89 \\
\hline & 11417500 & $03 / 11 / 02$ & 0910 & 747 & 10 \\
\hline & 11417500 & 03/11/02 & 0910 & 747 & 9 \\
\hline & 11417500 & $03 / 12 / 02$ & 0920 & 654 & 5 \\
\hline & 11417500 & $03 / 12 / 02$ & 0920 & 654 & 5 \\
\hline & 11417500 & 03/13/02 & 0855 & 603 & 2 \\
\hline & 11417500 & 03/13/02 & 0855 & 603 & 4 \\
\hline & 11417500 & $03 / 14 / 02$ & 0910 & 532 & 4 \\
\hline & 11417500 & 03/14/02 & 0910 & 532 & 5 \\
\hline & 11417500 & $03 / 15 / 02$ & 0915 & 466 & 4 \\
\hline & 11417500 & $03 / 15 / 02$ & 0915 & 466 & 10 \\
\hline & 11417500 & 03/18/02 & 0920 & 390 & 2 \\
\hline & 11417500 & $03 / 18 / 02$ & 0920 & 390 & 2 \\
\hline & 11417500 & 03/19/02 & 0920 & 390 & 34 \\
\hline & 11417500 & 03/19/02 & 0920 & 390 & 33 \\
\hline & 11417500 & $03 / 20 / 02$ & 0910 & 365 & 6 \\
\hline & 11417500 & $03 / 20 / 02$ & 0910 & 365 & 5 \\
\hline & 11417500 & $03 / 21 / 02$ & 0910 & 358 & 3 \\
\hline & 11417500 & $03 / 21 / 02$ & 0910 & 358 & 4 \\
\hline & 11417500 & $03 / 22 / 02$ & 0920 & 360 & 3 \\
\hline & 11417500 & $03 / 22 / 02$ & 0920 & 360 & 3 \\
\hline & 11417500 & $03 / 24 / 02$ & 0915 & 1260 & 64 \\
\hline & 11417500 & $03 / 24 / 02$ & 0915 & 1260 & 55 \\
\hline & 11417500 & $03 / 25 / 02$ & 1020 & 818 & 13 \\
\hline & 11417500 & $03 / 25 / 02$ & 1020 & 818 & 14 \\
\hline & 11417500 & $03 / 26 / 02$ & 0925 & 665 & 6 \\
\hline & 11417500 & $03 / 26 / 02$ & 0925 & 665 & 7 \\
\hline
\end{tabular}

Table A1b. Suspended-sediment concentration samples and associated instantaneous streamflow for the South Yuba River at Jones Bar near Grass Valley (SYG) collected during water years 2001, 2002, and 2003.

[USGS Marina sediment laboratory uses $0.5 \mathrm{mg} / \mathrm{L}$ (milligram per liter) as the detection limit for reporting suspended-sediment concentration (SSC); therefore, samples with SSC of less than $0.5 \mathrm{mg} / \mathrm{L}$ are reported as $0.25 \mathrm{mg} / \mathrm{L}$ (Helsel and Hirsch, 1992). $\mathrm{ft}^{3} / \mathrm{s}$, cubic feet per second]

\begin{tabular}{cccc}
\hline Map Station & & Instan- & Suspended- \\
iden- & Daneous & Time & sediment
\end{tabular}

iden-
tifier

\begin{tabular}{rrrcc}
\hline SYG 11417500 & $03 / 27 / 02$ & 0920 & 580 & $(\mathrm{mg} / \mathrm{L})$ \\
11417500 & $03 / 27 / 02$ & 0920 & 580 & 4 \\
11417500 & $03 / 28 / 02$ & 0910 & 532 & 7
\end{tabular}

$11417500 \quad 03 / 28 / 0$

$11417500 \quad 03 / 29 / 02$

0910

$11417500 \quad 03 / 29 / 02$

$11417500 \quad 04 / 02 / 02$

$11417500 \quad 04 / 02 / 02$

$11417500 \quad 04 / 03 / 02$

$11417500 \quad 04 / 03 / 02$

$11417500 \quad 04 / 04 / 02$

$11417500 \quad 04 / 04 / 02$

$11417500 \quad 04 / 05 / 02$

0910

532

5

0910

541

0925

541

0925

0915

0915

0920

0920

0920

$11417500 \quad 04 / 05 / 02$

$11417500 \quad 04 / 08 / 02$

0920

$11417500 \quad 04 / 08 / 02$

0915

$11417500 \quad 04 / 09 / 02$

0915

0925

$11417500 \quad 04 / 09 / 02$

0925

$11417500 \quad 04 / 10 / 02$

$11417500 \quad 04 / 10 / 02$

0910

$11417500 \quad 04 / 11 / 02$

0910

$11417500 \quad 04 / 11 / 02$

0910

0910

$11417500 \quad 04 / 15 / 02$

$11417500 \quad 04 / 15 / 02$

0920

0920

$11417500 \quad 04 / 16 / 02$

$11417500 \quad 04 / 16 / 02$

0905

0905

$11417500 \quad 04 / 17 / 02$

$11417500 \quad 04 / 17 / 02$

0920

0920

$11417500 \quad 04 / 18 / 02$

0910

$11417500 \quad 04 / 18 / 02$

0910

$11417500 \quad 04 / 19 / 02$

0920

$11417500 \quad 04 / 19 / 02$

$11417500 \quad 04 / 22 / 02$

0920

0855

$11417500 \quad 04 / 22 / 02$

$11417500 \quad 04 / 23 / 02$

0855

0920

$11417500 \quad 04 / 23 / 02$

$11417500 \quad 04 / 24 / 02$

0920

0905

$11417500 \quad 04 / 24 / 02$

$11417500 \quad 04 / 25 / 02$

0905

0915

$11417500 \quad 04 / 25 / 02$

$11417500 \quad 04 / 26 / 02$

0915

0905

$11417500 \quad 04 / 26 / 02$

$11417500 \quad 04 / 30 / 02$

$11417500 \quad 04 / 30 / 02$

0905

0925

0925

$11417500 \quad 05 / 01 / 02$

$11417500 \quad 05 / 01 / 02$

0900

0900

0915

$11417500 \quad 05 / 02 / 02$
532

532

546

546

559

559

543

543

439

439

418

418

448

448

428

428

448

448

352

352

356

356

346

346

312

312

280

280

282

282

280

280

279

279

279

279

265

265

232

232

229
3

3

2

3

3

4

2

3

2

2

2

3

5

3

3

3

2

2

3

3

2

2

2

2

5

0.25

3

10

1

1

3

2

1

3

2

3

3
3

3
2

2
0.25

0.25

1

0.25 
Table A1b. Suspended-sediment concentration samples and associated instantaneous streamflow for the South Yuba River at Jones Bar near Grass Valley (SYG) collected during water years 2001, 2002, and 2003.

[USGS Marina sediment laboratory uses $0.5 \mathrm{mg} / \mathrm{L}$ (milligram per liter) as the detection limit for reporting suspended-sediment concentration (SSC); therefore, samples with SSC of less than $0.5 \mathrm{mg} / \mathrm{L}$ are reported as $0.25 \mathrm{mg} / \mathrm{L}$ (Helsel and Hirsch, 1992). $\mathrm{ft}^{3} / \mathrm{s}$, cubic feet per second]

\begin{tabular}{|c|c|c|c|c|c|}
\hline $\begin{array}{l}\text { Map } \\
\text { iden- } \\
\text { tifier }\end{array}$ & $\begin{array}{l}\text { Station } \\
\text { identifier }\end{array}$ & Date & Time & $\begin{array}{c}\text { Instan- } \\
\text { taneous } \\
\text { streamflow } \\
\left(\mathrm{ft}^{3} / \mathrm{s}\right) \\
\end{array}$ & $\begin{array}{l}\text { Suspended- } \\
\text { sediment } \\
\text { concentration } \\
(\mathrm{mg} / \mathrm{L})\end{array}$ \\
\hline \multirow[t]{47}{*}{$\overline{\text { SYG }}$} & 11417500 & $05 / 02 / 02$ & 0915 & 229 & 1 \\
\hline & 11417500 & $05 / 03 / 02$ & 0855 & 224 & 4 \\
\hline & 11417500 & $05 / 03 / 02$ & 0855 & 224 & 1 \\
\hline & 11417500 & $05 / 06 / 02$ & 0915 & 223 & 6 \\
\hline & 11417500 & $05 / 06 / 02$ & 0915 & 223 & 4 \\
\hline & 11417500 & 05/07/02 & 0915 & 227 & 2 \\
\hline & 11417500 & $05 / 07 / 02$ & 0915 & 227 & 2 \\
\hline & 11417500 & 05/08/02 & 0920 & 236 & 1 \\
\hline & 11417500 & 05/08/02 & 0920 & 236 & 1 \\
\hline & 11417500 & $05 / 09 / 02$ & 0920 & 212 & 1 \\
\hline & 11417500 & 05/09/02 & 9200 & 212 & 1 \\
\hline & 11417500 & $05 / 10 / 02$ & 0905 & 204 & 0.25 \\
\hline & 11417500 & 05/10/02 & 0905 & 204 & 1 \\
\hline & 11417500 & $05 / 13 / 02$ & 0855 & 196 & 1 \\
\hline & 11417500 & $05 / 13 / 02$ & 0855 & 196 & 2 \\
\hline & 11417500 & $05 / 14 / 02$ & 0920 & 194 & 0.25 \\
\hline & 11417500 & $05 / 14 / 02$ & 0920 & 194 & 0.25 \\
\hline & 11417500 & $05 / 15 / 02$ & 0915 & 190 & 0.25 \\
\hline & 11417500 & $05 / 15 / 02$ & 0915 & 190 & 10 \\
\hline & 11417500 & $05 / 16 / 02$ & 0930 & 186 & 0.25 \\
\hline & 11417500 & $05 / 16 / 02$ & 0930 & 186 & 0.25 \\
\hline & 11417500 & $05 / 17 / 02$ & 0920 & 180 & 0.25 \\
\hline & 11417500 & $05 / 17 / 02$ & 0920 & 180 & 1 \\
\hline & 11417500 & $05 / 20 / 02$ & 0915 & 218 & 9 \\
\hline & 11417500 & $05 / 20 / 02$ & 0915 & 218 & 3 \\
\hline & 11417500 & $05 / 21 / 02$ & 0930 & 439 & 24 \\
\hline & 11417500 & $05 / 21 / 02$ & 0930 & 439 & 28 \\
\hline & 11417500 & $05 / 22 / 02$ & 0915 & 383 & 2 \\
\hline & 11417500 & $05 / 22 / 02$ & 0915 & 383 & 2 \\
\hline & 11417500 & $05 / 23 / 02$ & 0935 & 727 & 12 \\
\hline & 11417500 & $05 / 23 / 02$ & 0935 & 727 & 11 \\
\hline & 11417500 & $05 / 24 / 02$ & 0910 & 698 & 5 \\
\hline & 11417500 & $05 / 24 / 02$ & 0910 & 698 & 4 \\
\hline & 11417500 & $05 / 28 / 02$ & 0915 & 433 & 0.25 \\
\hline & 11417500 & $05 / 28 / 02$ & 0915 & 433 & 1 \\
\hline & 11417500 & $05 / 29 / 02$ & 0920 & 243 & 7 \\
\hline & 11417500 & $05 / 29 / 02$ & 0920 & 243 & 6 \\
\hline & 11417500 & $05 / 30 / 02$ & 0905 & 196 & 3 \\
\hline & 11417500 & $05 / 30 / 02$ & 0905 & 196 & 3 \\
\hline & 11417500 & $05 / 31 / 02$ & 0915 & 463 & 3 \\
\hline & 11417500 & $05 / 31 / 02$ & 0915 & 463 & 4 \\
\hline & 11417500 & $06 / 04 / 02$ & 1130 & 445 & 1 \\
\hline & 11417500 & $06 / 04 / 02$ & 1130 & 445 & 1 \\
\hline & 11417500 & 06/06/02 & 1130 & 388 & 2 \\
\hline & 11417500 & $06 / 06 / 02$ & 1130 & 388 & 1 \\
\hline & 11417500 & $06 / 10 / 02$ & 0920 & 99 & 1 \\
\hline & 11417500 & 06/10/02 & 0920 & 99 & 1 \\
\hline
\end{tabular}

Table A1b. Suspended-sediment concentration samples and associated instantaneous streamflow for the South Yuba River at Jones Bar near Grass Valley (SYG) collected during water years 2001, 2002, and 2003.

[USGS Marina sediment laboratory uses $0.5 \mathrm{mg} / \mathrm{L}$ (milligram per liter) as the detection limit for reporting suspended-sediment concentration (SSC); therefore, samples with SSC of less than $0.5 \mathrm{mg} / \mathrm{L}$ are reported as $0.25 \mathrm{mg} / \mathrm{L}$ (Helsel and Hirsch, 1992). $\mathrm{ft}^{3} / \mathrm{s}$, cubic feet per second]

\begin{tabular}{|c|c|c|c|c|c|}
\hline $\begin{array}{l}\text { Map } \\
\text { iden- } \\
\text { tifier }\end{array}$ & $\begin{array}{c}\text { Station } \\
\text { identifier }\end{array}$ & Date & Time & $\begin{array}{c}\text { Instan- } \\
\text { taneous } \\
\text { streamflow } \\
\left(\mathrm{ft}^{3} / \mathrm{s}\right)\end{array}$ & $\begin{array}{l}\text { Suspended- } \\
\text { sediment } \\
\text { concentration } \\
(\mathrm{mg} / \mathrm{L})\end{array}$ \\
\hline \multirow[t]{47}{*}{$\overline{\text { SYG }}$} & 11417500 & $06 / 11 / 02$ & 0925 & 98 & 2 \\
\hline & 11417500 & 06/11/02 & 0925 & 98 & 0.25 \\
\hline & 11417500 & $06 / 12 / 02$ & 0910 & 92 & 2 \\
\hline & 11417500 & $06 / 12 / 02$ & 0910 & 92 & 2 \\
\hline & 11417500 & 06/13/02 & 0930 & 87 & 1 \\
\hline & 11417500 & 06/13/02 & 0930 & 87 & 1 \\
\hline & 11417500 & $06 / 14 / 02$ & 0920 & 80 & 1 \\
\hline & 11417500 & $06 / 14 / 02$ & 0920 & 80 & 2 \\
\hline & 11417500 & 06/18/02 & 0930 & 79 & 3 \\
\hline & 11417500 & 06/18/02 & 0930 & 79 & 2 \\
\hline & 11417500 & 06/19/02 & 0830 & 79 & 0.25 \\
\hline & 11417500 & 06/19/02 & 0830 & 79 & 1 \\
\hline & 11417500 & 06/20/02 & 0830 & 78 & 1 \\
\hline & 11417500 & 06/20/02 & 0830 & 78 & 2 \\
\hline & 11417500 & $06 / 21 / 02$ & 0810 & 74 & 1 \\
\hline & 11417500 & $06 / 21 / 02$ & 0810 & 74 & 2 \\
\hline & 11417500 & $06 / 24 / 02$ & 0920 & 72 & 2 \\
\hline & 11417500 & $06 / 24 / 02$ & 0920 & 72 & 3 \\
\hline & 11417500 & $06 / 25 / 02$ & 0920 & 70 & 2 \\
\hline & 11417500 & $06 / 25 / 02$ & 0920 & 70 & 3 \\
\hline & 11417500 & 06/27/02 & 0910 & 67 & 1 \\
\hline & 11417500 & 06/27/02 & 0910 & 67 & 1 \\
\hline & 11417500 & 06/28/02 & 0900 & 67 & 1 \\
\hline & 11417500 & 06/28/02 & 0900 & 67 & 4 \\
\hline & 11417500 & $11 / 05 / 02$ & 1018 & 43 & 1 \\
\hline & 11417500 & $11 / 05 / 02$ & 1018 & 43 & 1 \\
\hline & 11417500 & $11 / 07 / 02$ & 1110 & 54 & 0.25 \\
\hline & 11417500 & $11 / 07 / 02$ & 1110 & 54 & 1 \\
\hline & 11417500 & 11/07/02 & 1300 & 56 & 0.25 \\
\hline & 11417500 & $11 / 07 / 02$ & 1300 & 56 & 2 \\
\hline & 11417500 & $11 / 07 / 02$ & 1500 & 60 & 4 \\
\hline & 11417500 & $11 / 07 / 02$ & 1500 & 60 & 2 \\
\hline & 11417500 & $11 / 07 / 02$ & 1630 & 64 & 1 \\
\hline & 11417500 & $11 / 07 / 02$ & 1630 & 64 & 1 \\
\hline & 11417500 & $11 / 08 / 02$ & 1040 & 280 & 133 \\
\hline & 11417500 & $11 / 08 / 02$ & 1040 & 280 & 134 \\
\hline & 11417500 & $11 / 08 / 02$ & 1150 & 338 & 125 \\
\hline & 11417500 & $11 / 08 / 02$ & 1150 & 338 & 121 \\
\hline & 11417500 & $11 / 08 / 02$ & 1400 & 409 & 78 \\
\hline & 11417500 & $11 / 08 / 02$ & 1400 & 409 & 85 \\
\hline & 11417500 & $11 / 08 / 02$ & 1530 & 397 & 69 \\
\hline & 11417500 & $11 / 08 / 02$ & 1530 & 397 & 70 \\
\hline & 11417500 & $11 / 09 / 02$ & 0845 & 463 & 39 \\
\hline & 11417500 & $11 / 09 / 02$ & 0845 & 463 & 32 \\
\hline & 11417500 & $11 / 09 / 02$ & 1045 & 417 & 32 \\
\hline & 11417500 & $11 / 09 / 02$ & 1045 & 417 & 31 \\
\hline & 11417500 & $11 / 12 / 02$ & 1335 & 163 & 9 \\
\hline
\end{tabular}


Table A1b. Suspended-sediment concentration samples and associated instantaneous streamflow for the South Yuba River at Jones Bar near Grass Valley (SYG) collected during water years 2001, 2002, and 2003.

[USGS Marina sediment laboratory uses $0.5 \mathrm{mg} / \mathrm{L}$ (milligram per liter) as the detection limit for reporting suspended-sediment concentration (SSC); therefore, samples with SSC of less than $0.5 \mathrm{mg} / \mathrm{L}$ are reported as $0.25 \mathrm{mg} / \mathrm{L}$ (Helsel and Hirsch, 1992). $\mathrm{ft}^{3} / \mathrm{s}$, cubic feet per second]

\begin{tabular}{|c|c|c|c|c|c|}
\hline $\begin{array}{l}\text { Map } \\
\text { iden- } \\
\text { tifier }\end{array}$ & $\begin{array}{l}\text { Station } \\
\text { identifier }\end{array}$ & Date & Time & $\begin{array}{c}\text { Instan- } \\
\text { taneous } \\
\text { streamflow } \\
\left(\mathrm{ft}^{3} / \mathrm{s}\right)\end{array}$ & $\begin{array}{l}\text { Suspended- } \\
\text { sediment } \\
\text { concentration } \\
(\mathrm{mg} / \mathrm{L})\end{array}$ \\
\hline \multirow[t]{47}{*}{$\overline{\mathrm{SYG}}$} & 11417500 & $11 / 12 / 02$ & 1335 & 163 & 8 \\
\hline & 11417500 & $11 / 13 / 02$ & 0900 & 120 & 6 \\
\hline & 11417500 & $11 / 13 / 02$ & 0900 & 120 & 3 \\
\hline & 11417500 & $11 / 15 / 02$ & 0915 & 86 & 2 \\
\hline & 11417500 & $11 / 15 / 02$ & 0915 & 86 & 4 \\
\hline & 11417500 & $11 / 18 / 02$ & 0850 & 70 & 2 \\
\hline & 11417500 & $11 / 18 / 02$ & 0850 & 70 & 2 \\
\hline & 11417500 & $11 / 20 / 02$ & 0930 & 67 & 0.25 \\
\hline & 11417500 & $11 / 20 / 02$ & 0930 & 67 & 1 \\
\hline & 11417500 & $11 / 22 / 02$ & 0905 & 64 & 2 \\
\hline & 11417500 & $11 / 22 / 02$ & 0905 & 64 & 1 \\
\hline & 11417500 & $11 / 25 / 02$ & 0900 & 62 & 0.25 \\
\hline & 11417500 & $11 / 25 / 02$ & 0900 & 62 & 1 \\
\hline & 11417500 & $11 / 27 / 02$ & 0835 & 58 & 3 \\
\hline & 11417500 & $11 / 27 / 02$ & 0835 & 58 & 0.25 \\
\hline & 11417500 & $12 / 02 / 02$ & 0900 & 58 & 0.25 \\
\hline & 11417500 & $12 / 02 / 02$ & 0900 & 58 & 0.25 \\
\hline & 11417500 & $12 / 04 / 02$ & 0850 & 58 & 0.25 \\
\hline & 11417500 & $12 / 04 / 02$ & 0850 & 58 & 2 \\
\hline & 11417500 & $12 / 06 / 02$ & 0855 & 57 & 1 \\
\hline & 11417500 & $12 / 06 / 02$ & 0855 & 57 & 1 \\
\hline & 11417500 & $12 / 09 / 02$ & 0845 & 56 & 0.25 \\
\hline & 11417500 & $12 / 09 / 02$ & 0845 & 56 & 0.25 \\
\hline & 11417500 & $12 / 11 / 02$ & 0840 & 99 & 2 \\
\hline & 11417500 & $12 / 11 / 02$ & 0840 & 99 & 2 \\
\hline & 11417500 & $12 / 13 / 02$ & 0840 & 80 & 4 \\
\hline & 11417500 & $12 / 13 / 02$ & 0840 & 80 & 2 \\
\hline & 11417500 & $12 / 13 / 02$ & 1040 & 87 & 9 \\
\hline & 11417500 & $12 / 13 / 02$ & 1040 & 87 & 2 \\
\hline & 11417500 & $12 / 13 / 02$ & 1240 & 101 & 4 \\
\hline & 11417500 & $12 / 13 / 02$ & 1240 & 101 & 3 \\
\hline & 11417500 & $12 / 13 / 02$ & 1445 & 147 & 19 \\
\hline & 11417500 & $12 / 13 / 02$ & 1445 & 147 & 23 \\
\hline & 11417500 & $12 / 13 / 02$ & 1600 & 221 & 63 \\
\hline & 11417500 & $12 / 13 / 02$ & 1600 & 221 & 63 \\
\hline & 11417500 & $12 / 14 / 02$ & 0800 & 1790 & 44 \\
\hline & 11417500 & $12 / 14 / 02$ & 0800 & 1790 & 141 \\
\hline & 11417500 & $12 / 14 / 02$ & 1148 & 1620 & 96 \\
\hline & 11417500 & $12 / 14 / 02$ & 1148 & 1620 & 74 \\
\hline & 11417500 & $12 / 14 / 02$ & 1440 & 1490 & 92 \\
\hline & 11417500 & $12 / 14 / 02$ & 1440 & 1490 & 84 \\
\hline & 11417500 & $12 / 15 / 02$ & 0740 & 1790 & 188 \\
\hline & 11417500 & $12 / 15 / 02$ & 0740 & 1790 & 191 \\
\hline & 11417500 & $12 / 15 / 02$ & 0940 & 1620 & 138 \\
\hline & 11417500 & $12 / 15 / 02$ & 0940 & 1620 & 143 \\
\hline & 11417500 & $12 / 15 / 02$ & 1140 & 1500 & 110 \\
\hline & 11417500 & $12 / 15 / 02$ & 1140 & 1500 & 56 \\
\hline
\end{tabular}

Table A1b. Suspended-sediment concentration samples and associated instantaneous streamflow for the South Yuba River at Jones Bar near Grass Valley (SYG) collected during water years 2001, 2002, and 2003.

[USGS Marina sediment laboratory uses $0.5 \mathrm{mg} / \mathrm{L}$ (milligram per liter) as the detection limit for reporting suspended-sediment concentration (SSC); therefore, samples with SSC of less than $0.5 \mathrm{mg} / \mathrm{L}$ are reported as $0.25 \mathrm{mg} / \mathrm{L}$ (Helsel and Hirsch, 1992). $\mathrm{ft}^{3} / \mathrm{s}$, cubic feet per second]

\begin{tabular}{llcc}
\hline Map Station & Instan- & $\begin{array}{c}\text { Suspended- } \\
\text { saneous }\end{array}$ \\
iden- & Timent
\end{tabular}

tifier identifier Date Time streamflow concentration

\begin{tabular}{rrrcc}
\hline SYG 11417500 & $12 / 15 / 02$ & 1340 & 1330 & $(\mathrm{mg} / \mathrm{L})$ \\
11417500 & $12 / 15 / 02$ & 1340 & 1330 & 56 \\
11417500 & $12 / 15 / 02$ & 1615 & 1160 & 42
\end{tabular}

$11417500-12 / 15 / 02$

$\begin{array}{lllll}11417500 & 12 / 16 / 02 & 1000 & 4600 & 401\end{array}$

$\begin{array}{lllll}11417500 & 12 / 16 / 02 & 1000 & 4600 & 374\end{array}$

$\begin{array}{lllll}11417500 & 12 / 16 / 02 & 1215 & 3650 & 304\end{array}$

$\begin{array}{lllll}11417500 & 12 / 16 / 02 & 1215 & 3650 & 360\end{array}$

$\begin{array}{lllll}11417500 & 12 / 16 / 02 & 1415 & 3110 & 244\end{array}$

$\begin{array}{lllll}11417500 & 12 / 16 / 02 & 1415 & 3110 & 237\end{array}$

$\begin{array}{lllll}11417500 & 12 / 16 / 02 & 1500 & 3010 & 209\end{array}$

$\begin{array}{lllll}11417500 & 12 / 16 / 02 & 1500 & 3010 & 198\end{array}$

$\begin{array}{lllll}11417500 & 12 / 17 / 02 & 0930 & 1240 & 30\end{array}$

$\begin{array}{lllll}11417500 & 12 / 17 / 02 & 0930 & 1240 & 31\end{array}$

$\begin{array}{lllll}11417500 & 12 / 17 / 02 & 1100 & 1170 & 27\end{array}$

$\begin{array}{lllll}11417500 & 12 / 17 / 02 & 1100 & 1170 & 28\end{array}$

$\begin{array}{lllll}11417500 & 12 / 17 / 02 & 1300 & 1090 & 26\end{array}$

$\begin{array}{lllll}11417500 & 12 / 17 / 02 & 1300 & 1090 & 24\end{array}$

$\begin{array}{lllll}11417500 & 12 / 17 / 02 & 1500 & 1020 & 23\end{array}$

$\begin{array}{lllll}11417500 & 12 / 17 / 02 & 1500 & 1020 & 24\end{array}$

$\begin{array}{lllll}11417500 & 12 / 17 / 02 & 1630 & 956 & 25\end{array}$

$\begin{array}{lllll}11417500 & 12 / 17 / 02 & 1630 & 956 & 23\end{array}$

$\begin{array}{lllll}11417500 & 12 / 18 / 02 & 0830 & 615 & 13\end{array}$

$\begin{array}{lllll}11417500 & 12 / 18 / 02 & 0830 & 615 & 9\end{array}$

$\begin{array}{lllll}11417500 & 12 / 18 / 02 & 1030 & 595 & 10\end{array}$

$\begin{array}{lllll}11417500 & 12 / 18 / 02 & 1030 & 595 & 12\end{array}$

$\begin{array}{lllll}11417500 & 12 / 18 / 02 & 1230 & 560 & 10\end{array}$

$\begin{array}{lllll}11417500 & 12 / 18 / 02 & 1230 & 560 & 11\end{array}$

$\begin{array}{lllll}11417500 & 12 / 20 / 02 & 0900 & 390 & 4\end{array}$

$\begin{array}{lllll}11417500 & 12 / 20 / 02 & 0900 & 390 & 3\end{array}$

$\begin{array}{lllll}11417500 & 12 / 23 / 02 & 0900 & 331 & 8\end{array}$

$\begin{array}{lllll}11417500 & 12 / 23 / 02 & 0900 & 331 & 7\end{array}$

$\begin{array}{lllll}11417500 & 12 / 27 / 02 & 0930 & 305 & 4\end{array}$

$\begin{array}{lllll}11417500 & 12 / 27 / 02 & 0930 & 305 & 3\end{array}$

$\begin{array}{lllll}11417500 & 12 / 30 / 02 & 0910 & 834 & 18\end{array}$

$\begin{array}{lllll}11417500 & 12 / 30 / 02 & 0910 & 834 & 16\end{array}$

$\begin{array}{lllll}11417500 & 12 / 30 / 02 & 1500 & 765 & 11\end{array}$

$\begin{array}{lllll}11417500 & 12 / 30 / 02 & 1500 & 765 & 11\end{array}$

$\begin{array}{lllll}11417500 & 01 / 03 / 03 & 0920 & 493 & 2\end{array}$

$\begin{array}{lllll}11417500 & 01 / 03 / 03 & 0920 & 493 & 2\end{array}$

$\begin{array}{lllll}11417500 & 01 / 06 / 03 & 0910 & 432 & 2\end{array}$

$\begin{array}{lllll}11417500 & 01 / 06 / 03 & 0910 & 432 & 3\end{array}$

$\begin{array}{lllll}11417500 & 01 / 08 / 03 & 0900 & 366 & 1\end{array}$

$\begin{array}{lllll}11417500 & 01 / 08 / 03 & 0900 & 366 & 2\end{array}$

$\begin{array}{lllll}11417500 & 01 / 10 / 03 & 0900 & 482 & 5\end{array}$

$\begin{array}{lllll}11417500 & 01 / 10 / 03 & 0900 & 482 & 5\end{array}$

$\begin{array}{lllll}11417500 & 01 / 13 / 03 & 0930 & 544 & 7\end{array}$ 
Table A1b. Suspended-sediment concentration samples and associated instantaneous streamflow for the South Yuba River at Jones Bar near Grass Valley (SYG) collected during water years 2001, 2002, and 2003.

[USGS Marina sediment laboratory uses $0.5 \mathrm{mg} / \mathrm{L}$ (milligram per liter) as the detection limit for reporting suspended-sediment concentration (SSC); therefore, samples with SSC of less than $0.5 \mathrm{mg} / \mathrm{L}$ are reported as $0.25 \mathrm{mg} / \mathrm{L}$ (Helsel and Hirsch, 1992). $\mathrm{ft}^{3} / \mathrm{s}$, cubic feet per second]

\begin{tabular}{|c|c|c|c|c|c|}
\hline $\begin{array}{l}\text { Map } \\
\text { iden- } \\
\text { tifier }\end{array}$ & $\begin{array}{l}\text { Station } \\
\text { identifier }\end{array}$ & Date & Time & $\begin{array}{c}\text { Instan- } \\
\text { taneous } \\
\text { streamflow } \\
\left(\mathrm{ft}^{3} / \mathrm{s}\right)\end{array}$ & $\begin{array}{l}\text { Suspended- } \\
\text { sediment } \\
\text { concentration } \\
(\mathrm{mg} / \mathrm{L})\end{array}$ \\
\hline \multirow[t]{47}{*}{ SYG } & 11417500 & $01 / 13 / 03$ & 0930 & 544 & 6 \\
\hline & 11417500 & $01 / 15 / 03$ & 1030 & 419 & 2 \\
\hline & 11417500 & $01 / 15 / 03$ & 1030 & 419 & 3 \\
\hline & 11417500 & 01/17/03 & 1030 & 327 & 1 \\
\hline & 11417500 & $01 / 17 / 03$ & 1030 & 327 & 1 \\
\hline & 11417500 & $01 / 21 / 03$ & 0905 & 301 & 0.25 \\
\hline & 11417500 & $01 / 21 / 03$ & 0905 & 301 & 2 \\
\hline & 11417500 & $01 / 23 / 03$ & 0920 & 742 & 23 \\
\hline & 11417500 & $01 / 23 / 03$ & 0920 & 742 & 23 \\
\hline & 11417500 & 01/27/03 & 0920 & 471 & 2 \\
\hline & 11417500 & 01/27/03 & 0920 & 471 & 2 \\
\hline & 11417500 & $01 / 31 / 03$ & 0930 & 356 & 2 \\
\hline & 11417500 & $01 / 31 / 03$ & 0930 & 356 & 2 \\
\hline & 11417500 & $02 / 03 / 03$ & 0955 & 320 & 1 \\
\hline & 11417500 & $02 / 03 / 03$ & 0955 & 320 & 0.25 \\
\hline & 11417500 & $02 / 05 / 03$ & 1000 & 275 & 0.25 \\
\hline & 11417500 & $02 / 05 / 03$ & 1000 & 275 & 1 \\
\hline & 11417500 & 02/07/03 & 0930 & 246 & 0.25 \\
\hline & 11417500 & 02/07/03 & 0930 & 246 & 0.25 \\
\hline & 11417500 & $02 / 10 / 03$ & 1140 & 211 & 1 \\
\hline & 11417500 & $02 / 10 / 03$ & 1140 & 211 & 1 \\
\hline & 11417500 & $02 / 12 / 03$ & 1105 & 199 & 0.25 \\
\hline & 11417500 & $02 / 12 / 03$ & 1105 & 199 & 0.25 \\
\hline & 11417500 & $02 / 14 / 03$ & 1015 & 501 & 16 \\
\hline & 11417500 & $02 / 14 / 03$ & 1015 & 501 & 18 \\
\hline & 11417500 & $02 / 15 / 03$ & 1320 & 295 & 2 \\
\hline & 11417500 & $02 / 15 / 03$ & 1320 & 295 & 1 \\
\hline & 11417500 & $02 / 15 / 03$ & 1500 & 291 & 1 \\
\hline & 11417500 & $02 / 15 / 03$ & 1500 & 291 & 1 \\
\hline & 11417500 & $02 / 15 / 03$ & 1700 & 288 & 2 \\
\hline & 11417500 & $02 / 15 / 03$ & 1700 & 288 & 3 \\
\hline & 11417500 & $02 / 16 / 03$ & 0700 & 661 & 34 \\
\hline & 11417500 & $02 / 16 / 03$ & 0700 & 661 & 33 \\
\hline & 11417500 & $02 / 16 / 03$ & 0945 & 636 & 162 \\
\hline & 11417500 & $02 / 16 / 03$ & 0945 & 636 & 168 \\
\hline & 11417500 & $02 / 16 / 03$ & 1200 & 661 & 243 \\
\hline & 11417500 & $02 / 16 / 03$ & 1400 & 643 & 5 \\
\hline & 11417500 & $02 / 16 / 03$ & 1400 & 643 & 12 \\
\hline & 11417500 & $02 / 16 / 03$ & 1530 & 633 & 6 \\
\hline & 11417500 & $02 / 16 / 03$ & 1530 & 633 & 9 \\
\hline & 11417500 & 02/17/03 & 0700 & 447 & 0.25 \\
\hline & 11417500 & $02 / 17 / 03$ & 0700 & 447 & 1 \\
\hline & 11417500 & $02 / 17 / 03$ & 0900 & 437 & 9 \\
\hline & 11417500 & $02 / 17 / 03$ & 0900 & 437 & 9 \\
\hline & 11417500 & $02 / 17 / 03$ & 1100 & 429 & 7 \\
\hline & 11417500 & $02 / 17 / 03$ & 1100 & 429 & 6 \\
\hline & 11417500 & $02 / 17 / 03$ & 1300 & 419 & 6 \\
\hline
\end{tabular}

Table A1b. Suspended-sediment concentration samples and associated instantaneous streamflow for the South Yuba River at Jones Bar near Grass Valley (SYG) collected during water years 2001, 2002, and 2003.

[USGS Marina sediment laboratory uses $0.5 \mathrm{mg} / \mathrm{L}$ (milligram per liter) as the detection limit for reporting suspended-sediment concentration (SSC); therefore, samples with SSC of less than $0.5 \mathrm{mg} / \mathrm{L}$ are reported as $0.25 \mathrm{mg} / \mathrm{L}$ (Helsel and Hirsch, 1992). $\mathrm{ft}^{3} / \mathrm{s}$, cubic feet per second]

\begin{tabular}{cccc}
\hline Map Station & Instan- & $\begin{array}{c}\text { Suspended- } \\
\text { taneous } \\
\text { iden- }\end{array}$ & sediment \\
streamflow & concentration
\end{tabular}

tifier identifier Date Time streamflow concentration

\begin{tabular}{llllcc}
\hline SYG 11417500 & $02 / 17 / 03$ & 1300 & 419 & $(\mathrm{mg} / \mathrm{L})$ \\
11417500 & $02 / 17 / 03$ & 1500 & 407 & 7 \\
& 11417500 & $02 / 17 / 03$ & 1500 & 407 & 2
\end{tabular}

$\begin{array}{lllll}11417500 & 02 / 18 / 03 & 0900 & 352 & 3\end{array}$

$11417500 \quad 02 / 18 / 03 \quad 0900 \quad 352 \quad 2$

$\begin{array}{lllll}11417500 & 02 / 18 / 03 & 1100 & 345 & 1\end{array}$

$\begin{array}{lllll}11417500 & 02 / 18 / 03 & 1100 & 345 & 2\end{array}$

$\begin{array}{lllll}11417500 & 02 / 19 / 03 & 0915 & 312 & 1\end{array}$

$\begin{array}{lllll}11417500 & 02 / 19 / 03 & 0915 & 312 & 3\end{array}$

$\begin{array}{lllll}11417500 & 02 / 21 / 03 & 0915 & 288 & 2\end{array}$

$\begin{array}{lllll}11417500 & 02 / 21 / 03 & 0915 & 288 & 3\end{array}$

$\begin{array}{lllll}11417500 & 02 / 24 / 03 & 0900 & 233 & 3\end{array}$

$\begin{array}{lllll}11417500 & 02 / 24 / 03 & 0900 & 233 & 4\end{array}$

$\begin{array}{lllll}11417500 & 02 / 26 / 03 & 0900 & 214 & 2\end{array}$

$\begin{array}{lllll}11417500 & 02 / 26 / 03 & 0900 & 214 & 2\end{array}$

$\begin{array}{lllll}11417500 & 02 / 28 / 03 & 0900 & 208 & 2\end{array}$

$\begin{array}{lllll}11417500 & 02 / 28 / 03 & 0900 & 208 & 2\end{array}$

$11417500 \quad 03 / 05 / 03 \quad 0850 \quad 170 \quad 2$

$\begin{array}{lllll}11417500 & 03 / 05 / 03 & 0850 & 170 & 1\end{array}$

$\begin{array}{lllll}11417500 & 03 / 07 / 03 & 0845 & 159 & 2\end{array}$

$\begin{array}{lllll}11417500 & 03 / 07 / 03 & 0845 & 159 & 4\end{array}$

$\begin{array}{lllll}11417500 & 03 / 10 / 03 & 0940 & 146 & 6\end{array}$

$\begin{array}{lllll}11417500 & 03 / 10 / 03 & 0940 & 146 & 3\end{array}$

$\begin{array}{lllll}11417500 & 03 / 12 / 03 & 1100 & 146 & 2\end{array}$

$\begin{array}{lllll}11417500 & 03 / 12 / 03 & 1100 & 146 & 2\end{array}$

$\begin{array}{lllll}11417500 & 03 / 13 / 03 & 1300 & 150 & 1\end{array}$

$\begin{array}{lllll}11417500 & 03 / 13 / 03 & 1300 & 150 & 13\end{array}$

$\begin{array}{lllll}11417500 & 03 / 13 / 03 & 1500 & 153 & 2\end{array}$

$\begin{array}{lllll}11417500 & 03 / 13 / 03 & 1500 & 153 & 3\end{array}$

$\begin{array}{lllll}11417500 & 03 / 14 / 03 & 0730 & 218 & 3\end{array}$

$\begin{array}{lllll}11417500 & 03 / 14 / 03 & 0730 & 218 & 3\end{array}$

$\begin{array}{lllll}11417500 & 03 / 14 / 03 & 0930 & 263 & 5\end{array}$

$\begin{array}{lllll}11417500 & 03 / 14 / 03 & 0930 & 263 & 3\end{array}$

$\begin{array}{lllll}11417500 & 03 / 14 / 03 & 1210 & 303 & 9\end{array}$

$\begin{array}{lllll}11417500 & 03 / 14 / 03 & 1210 & 303 & 12\end{array}$

$\begin{array}{lllll}11417500 & 03 / 14 / 03 & 1400 & 340 & 10\end{array}$

$\begin{array}{lllll}11417500 & 03 / 14 / 03 & 1400 & 340 & 7\end{array}$

$\begin{array}{lllll}11417500 & 03 / 14 / 03 & 1530 & 395 & 44\end{array}$

$\begin{array}{lllll}11417500 & 03 / 14 / 03 & 1530 & 395 & 40\end{array}$

$\begin{array}{lllll}11417500 & 03 / 14 / 03 & 1530 & 395 & 112\end{array}$

$\begin{array}{lllll}11417500 & 03 / 14 / 03 & 1530 & 395 & 120\end{array}$

$\begin{array}{lllll}11417500 & 03 / 15 / 03 & 0730 & 2170 & 623\end{array}$

$\begin{array}{lllll}11417500 & 03 / 15 / 03 & 0730 & 2170 & 577\end{array}$

$\begin{array}{lllll}11417500 & 03 / 15 / 03 & 0930 & 2540 & 393\end{array}$

$\begin{array}{lllll}11417500 & 03 / 15 / 03 & 0930 & 2540 & 330\end{array}$

$\begin{array}{lllll}11417500 & 03 / 15 / 03 & 1130 & 2790 & 392\end{array}$

$\begin{array}{lllll}11417500 & 03 / 15 / 03 & 1130 & 2790 & 385\end{array}$ 
Table A1b. Suspended-sediment concentration samples and associated instantaneous streamflow for the South Yuba River at Jones Bar near Grass Valley (SYG) collected during water years 2001, 2002, and 2003.

[USGS Marina sediment laboratory uses $0.5 \mathrm{mg} / \mathrm{L}$ (milligram per liter) as the detection limit for reporting suspended-sediment concentration (SSC); therefore, samples with SSC of less than $0.5 \mathrm{mg} / \mathrm{L}$ are reported as $0.25 \mathrm{mg} / \mathrm{L}$ (Helsel and Hirsch, 1992). $\mathrm{ft}^{3} / \mathrm{s}$, cubic feet per second]

\begin{tabular}{|c|c|c|c|c|c|}
\hline $\begin{array}{l}\text { Map } \\
\text { iden- } \\
\text { tifier }\end{array}$ & $\begin{array}{l}\text { Station } \\
\text { identifier }\end{array}$ & Date & Time & $\begin{array}{c}\text { Instan- } \\
\text { taneous } \\
\text { streamflow } \\
\left(\mathrm{ft}^{3} / \mathrm{s}\right)\end{array}$ & $\begin{array}{l}\text { Suspended- } \\
\text { sediment } \\
\text { concentration } \\
(\mathrm{mg} / \mathrm{L})\end{array}$ \\
\hline \multirow[t]{47}{*}{ SYG } & 11417500 & $03 / 15 / 03$ & 1330 & 3160 & 334 \\
\hline & 11417500 & 03/15/03 & 1330 & 3160 & 353 \\
\hline & 11417500 & 03/15/03 & 1530 & 2810 & 191 \\
\hline & 11417500 & 03/15/03 & 1530 & 2810 & 182 \\
\hline & 11417500 & 03/16/03 & 0800 & 1110 & 19 \\
\hline & 11417500 & 03/16/03 & 0800 & 1110 & 19 \\
\hline & 11417500 & 03/16/03 & 1000 & 1050 & 20 \\
\hline & 11417500 & 03/16/03 & 1000 & 1050 & 22 \\
\hline & 11417500 & 03/16/03 & 1200 & 983 & 18 \\
\hline & 11417500 & 03/16/03 & 1200 & 983 & 18 \\
\hline & 11417500 & 03/16/03 & 1400 & 929 & 13 \\
\hline & 11417500 & 03/16/03 & 1400 & 929 & 17 \\
\hline & 11417500 & 03/16/03 & 1630 & 885 & 11 \\
\hline & 11417500 & 03/16/03 & 1630 & 885 & 12 \\
\hline & 11417500 & 03/17/03 & 0830 & 686 & 6 \\
\hline & 11417500 & 03/17/03 & 0830 & 686 & 9 \\
\hline & 11417500 & 03/19/03 & 0910 & 437 & 3 \\
\hline & 11417500 & 03/19/03 & 0910 & 437 & 2 \\
\hline & 11417500 & 03/21/03 & 1000 & 434 & 3 \\
\hline & 11417500 & $03 / 21 / 03$ & 1000 & 434 & 4 \\
\hline & 11417500 & $03 / 24 / 03$ & 0930 & 541 & 4 \\
\hline & 11417500 & $03 / 24 / 03$ & 0930 & 541 & 4 \\
\hline & 11417500 & $03 / 26 / 03$ & 0920 & 434 & 3 \\
\hline & 11417500 & 03/26/03 & 0920 & 434 & 4 \\
\hline & 11417500 & 03/28/03 & 0910 & 487 & 1 \\
\hline & 11417500 & 03/28/03 & 0910 & 487 & 2 \\
\hline & 11417500 & 04/03/03 & 1000 & 409 & 9 \\
\hline & 11417500 & 04/03/03 & 1000 & 409 & 7 \\
\hline & 11417500 & 04/09/03 & 0905 & 442 & 2 \\
\hline & 11417500 & 04/09/03 & 0905 & 442 & 3 \\
\hline & 11417500 & 04/11/03 & 0925 & 422 & 1 \\
\hline & 11417500 & 04/11/03 & 0925 & 422 & 1 \\
\hline & 11417500 & $04 / 14 / 03$ & 0900 & 1190 & 23 \\
\hline & 11417500 & $04 / 14 / 03$ & 0900 & 1190 & 21 \\
\hline & 11417500 & 04/16/03 & 0850 & 738 & 4 \\
\hline & 11417500 & 04/16/03 & 0850 & 738 & 4 \\
\hline & 11417500 & 04/18/03 & 0900 & 708 & 4 \\
\hline & 11417500 & 04/18/03 & 0900 & 708 & 2 \\
\hline & 11417500 & $04 / 21 / 03$ & 0925 & 629 & 3 \\
\hline & 11417500 & $04 / 21 / 03$ & 0925 & 629 & 3 \\
\hline & 11417500 & $04 / 23 / 03$ & 0855 & 576 & 2 \\
\hline & 11417500 & $04 / 23 / 03$ & 0855 & 576 & 2 \\
\hline & 11417500 & 04/28/03 & 0925 & 1190 & 12 \\
\hline & 11417500 & $04 / 28 / 03$ & 0925 & 1190 & 21 \\
\hline & 11417500 & 04/30/03 & 0910 & 1020 & 11 \\
\hline & 11417500 & $04 / 30 / 03$ & 0910 & 1020 & 13 \\
\hline & 11417500 & $05 / 02 / 03$ & 0855 & 851 & 4 \\
\hline
\end{tabular}

Table A1b. Suspended-sediment concentration samples and associated instantaneous streamflow for the South Yuba River at Jones Bar near Grass Valley (SYG) collected during water years 2001, 2002, and 2003.

[USGS Marina sediment laboratory uses $0.5 \mathrm{mg} / \mathrm{L}$ (milligram per liter) as the detection limit for reporting suspended-sediment concentration (SSC); therefore, samples with SSC of less than $0.5 \mathrm{mg} / \mathrm{L}$ are reported as $0.25 \mathrm{mg} / \mathrm{L}$ (Helsel and Hirsch, 1992). $\mathrm{ft}^{3} / \mathrm{s}$, cubic feet per second]

\begin{tabular}{ccccc}
\hline $\begin{array}{c}\text { Map } \\
\text { iden- } \begin{array}{c}\text { Station } \\
\text { iffier }\end{array}\end{array}$ Dentifier & Date & Time & $\begin{array}{c}\text { Instan- } \\
\text { taneous } \\
\text { streamflow } \\
\left(\mathrm{ft}^{3} / \mathrm{s}\right)\end{array}$ & $\begin{array}{c}\text { Suspended- } \\
\text { sediment } \\
\text { concentration } \\
\text { (mg/L) }\end{array}$ \\
\hline SYG 11417500 & $05 / 02 / 03$ & 0855 & 851 & 4 \\
11417500 & $05 / 05 / 03$ & 0930 & 1330 & 12 \\
11417500 & $05 / 05 / 03$ & 0930 & 1330 & 10 \\
11417500 & $05 / 06 / 03$ & 0850 & 1140 & 5 \\
11417500 & $05 / 06 / 03$ & 0850 & 1140 & 6 \\
11417500 & $05 / 07 / 03$ & 0930 & 965 & 5 \\
11417500 & $05 / 07 / 03$ & 0930 & 965 & 3 \\
11417500 & $05 / 08 / 03$ & 0910 & 1220 & 13 \\
11417500 & $05 / 08 / 03$ & 0910 & 1220 & 10 \\
11417500 & $05 / 09 / 03$ & 0850 & 1210 & 16 \\
11417500 & $05 / 09 / 03$ & 0850 & 1210 & 15 \\
11417500 & $05 / 14 / 03$ & 0930 & 1040 & 5 \\
11417500 & $05 / 14 / 03$ & 0930 & 1040 & 4 \\
11417500 & $05 / 16 / 03$ & 0855 & 1050 & 2 \\
11417500 & $05 / 16 / 03$ & 0855 & 1050 & 2 \\
11417500 & $05 / 19 / 03$ & 0925 & 872 & 3 \\
11417500 & $05 / 19 / 03$ & 0925 & 872 & 2 \\
11417500 & $05 / 21 / 03$ & 0925 & 1090 & 4 \\
11417500 & $05 / 21 / 03$ & 0925 & 1090 & 5 \\
11417500 & $05 / 22 / 03$ & 1155 & 1160 & 5 \\
11417500 & $05 / 22 / 03$ & 1155 & 1160 & 6 \\
11417500 & $05 / 23 / 03$ & 0940 & 1410 & 12 \\
11417500 & $05 / 23 / 03$ & 0940 & 1410 & 10 \\
11417500 & $05 / 27 / 03$ & 0910 & 1460 & 6 \\
11417500 & $05 / 27 / 03$ & 0910 & 1460 & 5 \\
11417500 & $05 / 29 / 03$ & 0855 & 1930 & 24 \\
11417500 & $05 / 29 / 03$ & 0855 & 1930 & 21 \\
\hline & & & &
\end{tabular}


Table A1c. Suspended-sediment concentration samples and associated instantaneous streamflow for the Yuba River below New Colgate Powerplant near French Corral (YRC) collected during water years 2001, 2002, and 2003.

[USGS Marina sediment laboratory uses $0.5 \mathrm{mg} / \mathrm{L}$ (milligram per liter) as the detection limit for reporting suspended-sediment concentration (SSC); therefore, samples with SSC of less than $0.5 \mathrm{mg} / \mathrm{L}$ are reported as $0.25 \mathrm{mg} / \mathrm{L}$ (Helsel and Hirsch, 1992). $\mathrm{ft}^{3} / \mathrm{s}$, cubic feet per second]

\begin{tabular}{|c|c|c|c|c|c|}
\hline $\begin{array}{l}\text { Map } \\
\text { identi- } \\
\text { fier }\end{array}$ & $\begin{array}{l}\text { Station } \\
\text { identifier }\end{array}$ & Date & Time & $\begin{array}{c}\text { Instan- } \\
\text { taneous } \\
\text { streamflow } \\
\left(\mathrm{ft}^{3} / \mathrm{s}\right)\end{array}$ & $\begin{array}{l}\text { Suspended- } \\
\text { sediment } \\
\text { concentra- } \\
\text { tion (mg/L) }\end{array}$ \\
\hline \multirow[t]{48}{*}{ YRC } & 11413700 & $01 / 09 / 01$ & 1430 & 107 & 3 \\
\hline & 11413700 & 01/11/01 & 1610 & 213 & 65 \\
\hline & 11413700 & $01 / 12 / 01$ & 1335 & 120 & 8 \\
\hline & 11413700 & 01/19/01 & 1145 & 82 & 11 \\
\hline & 11413700 & $01 / 22 / 01$ & 1105 & 77 & 16 \\
\hline & 11413700 & $01 / 23 / 01$ & 1235 & 77 & 53 \\
\hline & 11413700 & 01/24/01 & 1300 & 155 & 61 \\
\hline & 11413700 & $01 / 25 / 01$ & 1220 & 3400 & 8 \\
\hline & 11413700 & $01 / 26 / 01$ & 1220 & 143 & 4 \\
\hline & 11413700 & 01/29/01 & 1230 & 107 & 2 \\
\hline & 11413700 & 01/30/01 & 1225 & 102 & 106 \\
\hline & 11413700 & 02/01/01 & 1225 & 125 & 2 \\
\hline & 11413700 & 02/02/01 & 1215 & 134 & 1 \\
\hline & 11413700 & $02 / 05 / 01$ & 1225 & 86 & 14 \\
\hline & 11413700 & 02/07/01 & 1215 & 86 & 4 \\
\hline & 11413700 & 02/08/01 & 1225 & 84 & 2 \\
\hline & 11413700 & 02/09/01 & 1220 & 86 & 8 \\
\hline & 11413700 & $02 / 11 / 01$ & 1250 & 257 & 303 \\
\hline & 11413700 & $02 / 12 / 01$ & 1210 & 175 & 19 \\
\hline & 11413700 & 02/13/01 & 1215 & 134 & 7 \\
\hline & 11413700 & 02/15/01 & 1210 & 112 & 2 \\
\hline & 11413700 & 02/16/01 & 1205 & 104 & 1 \\
\hline & 11413700 & 02/19/01 & 1205 & 125 & 2 \\
\hline & 11413700 & $02 / 20 / 01$ & 1225 & 281 & 28 \\
\hline & 11413700 & $02 / 22 / 01$ & 1215 & 402 & 16 \\
\hline & 11413700 & $02 / 23 / 01$ & 1215 & 239 & 7 \\
\hline & 11413700 & 02/26/01 & 1230 & 165 & 6 \\
\hline & 11413700 & $02 / 28 / 01$ & 1220 & 2060 & 4 \\
\hline & 11413700 & $02 / 28 / 01$ & 1600 & 778 & 5 \\
\hline & 11413700 & 03/02/01 & 1220 & 165 & 6 \\
\hline & 11413700 & 03/05/01 & 1220 & 252 & 10 \\
\hline & 11413700 & 03/07/01 & 1245 & 1030 & 7 \\
\hline & 11413700 & 03/09/01 & 1230 & 152 & 2 \\
\hline & 11413700 & 03/12/01 & 1215 & 120 & 6 \\
\hline & 11413700 & 03/14/01 & 1230 & 128 & 1175 \\
\hline & 11413700 & $03 / 15 / 01$ & 1315 & 109 & 5 \\
\hline & 11413700 & 03/16/01 & 1225 & 107 & 7 \\
\hline & 11413700 & 03/19/01 & 1215 & 3380 & 2 \\
\hline & 11413700 & $03 / 21 / 01$ & 1235 & 104 & 4 \\
\hline & 11413700 & 03/26/01 & 0915 & 469 & 313 \\
\hline & 11413700 & 03/28/01 & 1225 & 1390 & 2 \\
\hline & 11413700 & 03/30/01 & 1235 & 438 & 3 \\
\hline & 11413700 & $04 / 02 / 01$ & 1230 & 438 & 2 \\
\hline & 11413700 & 04/04/01 & 1220 & 420 & 3 \\
\hline & 11413700 & 04/06/01 & 1235 & 99.6 & 1 \\
\hline & 11413700 & 04/06/01 & 1235 & 99.6 & 4 \\
\hline & 11413700 & 04/09/01 & 1230 & 115 & 1 \\
\hline & 11413700 & $04 / 09 / 01$ & 1230 & 115 & 1 \\
\hline
\end{tabular}

Table A1c. Suspended-sediment concentration samples and associated instantaneous streamflow for the Yuba River below New Colgate Powerplant near French Corral (YRC) collected during water years 2001, 2002, and 2003.

[USGS Marina sediment laboratory uses $0.5 \mathrm{mg} / \mathrm{L}$ (milligram per liter) as the detection limit for reporting suspended-sediment concentration (SSC); therefore, samples with SSC of less than $0.5 \mathrm{mg} / \mathrm{L}$ are reported as $0.25 \mathrm{mg} / \mathrm{L}$ (Helsel and Hirsch, 1992). ft ${ }^{3} / \mathrm{s}$, cubic feet per second]

\begin{tabular}{|c|c|c|c|c|c|}
\hline $\begin{array}{l}\text { Map } \\
\text { identi- } \\
\text { fier }\end{array}$ & $\begin{array}{l}\text { Station } \\
\text { identifier }\end{array}$ & Date & Time & $\begin{array}{c}\text { Instan- } \\
\text { taneous } \\
\text { streamflow } \\
\left(\mathrm{ft}^{3} / \mathrm{s}\right)\end{array}$ & $\begin{array}{l}\text { Suspended- } \\
\text { sediment } \\
\text { concentra- } \\
\text { tion (mg/L) }\end{array}$ \\
\hline \multirow[t]{48}{*}{ YRC } & 11413700 & $04 / 11 / 01$ & 1230 & 125 & 2 \\
\hline & 11413700 & 04/11/01 & 1230 & 125 & 2 \\
\hline & 11413700 & $04 / 13 / 01$ & 1215 & 851 & 1 \\
\hline & 11413700 & $04 / 13 / 01$ & 1215 & 851 & 1 \\
\hline & 11413700 & $04 / 16 / 01$ & 1220 & 2150 & 2 \\
\hline & 11413700 & 04/16/01 & 1220 & 2150 & 5 \\
\hline & 11413700 & $04 / 18 / 01$ & 1230 & 134 & 2 \\
\hline & 11413700 & $04 / 18 / 01$ & 1230 & 134 & 1 \\
\hline & 11413700 & $04 / 20 / 01$ & 1230 & 1440 & 5 \\
\hline & 11413700 & $04 / 20 / 01$ & 1230 & 1440 & 1 \\
\hline & 11413700 & 04/23/01 & 1225 & 718 & 2 \\
\hline & 11413700 & $04 / 23 / 01$ & 1225 & 718 & 1 \\
\hline & 11413700 & $04 / 25 / 01$ & 1220 & 2030 & 2 \\
\hline & 11413700 & $04 / 25 / 01$ & 1220 & 2030 & 20 \\
\hline & 11413700 & $04 / 30 / 01$ & 1215 & 2040 & 2 \\
\hline & 11413700 & $05 / 02 / 01$ & 1245 & 123 & 2 \\
\hline & 11413700 & $05 / 04 / 01$ & 1230 & 2000 & 2 \\
\hline & 11413700 & 05/07/01 & 1230 & 1840 & 1 \\
\hline & 11413700 & $05 / 09 / 01$ & 1215 & 2530 & 1 \\
\hline & 11413700 & $05 / 11 / 01$ & 1200 & 3120 & 2 \\
\hline & 11413700 & $05 / 14 / 01$ & 1215 & 1660 & 1 \\
\hline & 11413700 & $05 / 16 / 01$ & 1225 & 943 & 19 \\
\hline & 11413700 & $05 / 18 / 01$ & 1200 & 2530 & 2 \\
\hline & 11413700 & $05 / 21 / 01$ & 1200 & 1780 & 1 \\
\hline & 11413700 & $05 / 22 / 01$ & 1205 & 2490 & 2 \\
\hline & 11413700 & $05 / 23 / 01$ & 1210 & 1320 & 1 \\
\hline & 11413700 & $05 / 25 / 01$ & 1215 & 887 & 4 \\
\hline & 11413700 & $05 / 29 / 01$ & 1215 & 2020 & 3 \\
\hline & 11413700 & $05 / 31 / 01$ & 1220 & 2750 & 2 \\
\hline & 11413700 & 06/04/01 & 1200 & 1240 & 2 \\
\hline & 11413700 & 06/06/01 & 1215 & 1490 & 2 \\
\hline & 11413700 & 06/08/01 & 1210 & 2120 & 2 \\
\hline & 11413700 & $06 / 11 / 01$ & 1215 & 1260 & 1 \\
\hline & 11413700 & $06 / 14 / 01$ & 1220 & 1900 & 1 \\
\hline & 11413700 & $06 / 18 / 01$ & 1225 & 2770 & 3 \\
\hline & 11413700 & $06 / 20 / 01$ & 1220 & 860 & 3 \\
\hline & 11413700 & $06 / 22 / 01$ & 1050 & 2700 & 1 \\
\hline & 11413700 & $06 / 25 / 01$ & 1225 & 693 & 2 \\
\hline & 11413700 & $06 / 27 / 01$ & 1230 & 2630 & 0 \\
\hline & 11413700 & $06 / 29 / 01$ & 1215 & 1240 & 1 \\
\hline & 11413700 & $07 / 02 / 01$ & 1205 & 1890 & 8 \\
\hline & 11413700 & $07 / 06 / 01$ & 1230 & 2890 & 4 \\
\hline & 11413700 & $07 / 09 / 01$ & 1215 & 2470 & 1 \\
\hline & 11413700 & $07 / 11 / 01$ & 1200 & 3260 & 1 \\
\hline & 11413700 & $07 / 13 / 01$ & 1210 & 2800 & 5 \\
\hline & 11413700 & $07 / 16 / 01$ & 1235 & 2720 & 24 \\
\hline & 11413700 & $07 / 18 / 01$ & 1220 & 2300 & 1 \\
\hline & 11413700 & $07 / 20 / 01$ & 1210 & 2180 & 8 \\
\hline
\end{tabular}


Table A1c. Suspended-sediment concentration samples and associated instantaneous streamflow for the Yuba River below New Colgate Powerplant near French Corral (YRC) collected during water years 2001, 2002, and 2003.

[USGS Marina sediment laboratory uses $0.5 \mathrm{mg} / \mathrm{L}$ (milligram per liter) as the detection limit for reporting suspended-sediment concentration (SSC); therefore, samples with SSC of less than $0.5 \mathrm{mg} / \mathrm{L}$ are reported as $0.25 \mathrm{mg} / \mathrm{L}$ (Helsel and Hirsch, 1992). ft³/s, cubic feet per second]

\begin{tabular}{|c|c|c|c|c|c|}
\hline $\begin{array}{l}\text { Map } \\
\text { identi- } \\
\text { fier }\end{array}$ & $\begin{array}{l}\text { Station } \\
\text { identifier }\end{array}$ & Date & Time & $\begin{array}{c}\text { Instan- } \\
\text { taneous } \\
\text { streamflow } \\
\left(\mathrm{ft}^{3} / \mathrm{s}\right)\end{array}$ & $\begin{array}{c}\text { Suspended- } \\
\text { sediment } \\
\text { concentra- } \\
\text { tion (mg/L) }\end{array}$ \\
\hline \multirow[t]{48}{*}{ YRC } & 11413700 & $07 / 23 / 01$ & 1315 & 2420 & 2 \\
\hline & 11413700 & $07 / 25 / 01$ & 1250 & 3340 & 1 \\
\hline & 11413700 & $07 / 27 / 01$ & 1215 & 1810 & 2 \\
\hline & 11413700 & $07 / 30 / 01$ & 1235 & 2820 & 2 \\
\hline & 11413700 & 08/01/01 & 1220 & 1530 & 2 \\
\hline & 11413700 & $08 / 02 / 01$ & 1210 & 3170 & 1 \\
\hline & 11413700 & 08/06/01 & 1245 & 3500 & 3 \\
\hline & 11413700 & 08/15/01 & 1500 & 3300 & 8 \\
\hline & 11413700 & $08 / 21 / 01$ & 1120 & 3420 & 1 \\
\hline & 11413700 & 08/29/01 & 1215 & 3130 & 12 \\
\hline & 11413700 & $09 / 11 / 01$ & 1035 & 2180 & 30 \\
\hline & 11413700 & $09 / 21 / 01$ & 1240 & 1600 & 3 \\
\hline & 11413700 & 09/27/01 & 1220 & 701 & 3 \\
\hline & 11413700 & $10 / 03 / 01$ & 1300 & 1810 & 4 \\
\hline & 11413700 & $10 / 10 / 01$ & 1225 & 896 & 2 \\
\hline & 11413700 & $10 / 17 / 01$ & 1145 & 878 & 4 \\
\hline & 11413700 & $10 / 24 / 01$ & 1245 & 2420 & 3 \\
\hline & 11413700 & $10 / 30 / 01$ & 1240 & 1580 & 2 \\
\hline & 11413700 & $10 / 31 / 01$ & 1340 & 1240 & 4 \\
\hline & 11413700 & $11 / 02 / 01$ & 1220 & 420 & 113 \\
\hline & 11413700 & $11 / 07 / 01$ & 1235 & 963 & 2 \\
\hline & 11413700 & $11 / 13 / 01$ & 1030 & 1860 & 3 \\
\hline & 11413700 & $11 / 16 / 01$ & 1255 & 117 & 3 \\
\hline & 11413700 & $11 / 26 / 01$ & 1220 & 1030 & 4 \\
\hline & 11413700 & $11 / 27 / 01$ & 1000 & 1010 & 2 \\
\hline & 11413700 & $11 / 28 / 01$ & 1215 & 972 & 2 \\
\hline & 11413700 & $11 / 29 / 01$ & 1140 & 117 & 111 \\
\hline & 11413700 & $12 / 03 / 01$ & 1225 & 271 & 23 \\
\hline & 11413700 & $12 / 05 / 01$ & 1218 & 261 & 3 \\
\hline & 11413700 & $12 / 06 / 01$ & 0925 & 556 & 20 \\
\hline & 11413700 & $12 / 07 / 01$ & 0915 & 234 & 6 \\
\hline & 11413700 & $12 / 11 / 01$ & 0930 & 123 & 6 \\
\hline & 11413700 & $12 / 12 / 01$ & 1205 & 115 & 1 \\
\hline & 11413700 & $12 / 14 / 01$ & 1225 & 291 & 14 \\
\hline & 11413700 & $12 / 15 / 01$ & 1145 & 169 & 5 \\
\hline & 11413700 & $12 / 18 / 01$ & 1225 & 306 & 8 \\
\hline & 11413700 & $12 / 19 / 01$ & 0930 & 197 & 4 \\
\hline & 11413700 & $12 / 20 / 01$ & 1230 & 301 & 3 \\
\hline & 11413700 & $12 / 26 / 01$ & 1215 & 149 & 7 \\
\hline & 11413700 & $12 / 28 / 01$ & 1140 & 134 & 7 \\
\hline & 11413700 & $12 / 31 / 01$ & 1105 & 1170 & 105 \\
\hline & 11413700 & $01 / 02 / 02$ & 1330 & 508 & 5 \\
\hline & 11413700 & 01/04/02 & 1135 & 301 & 4 \\
\hline & 11413700 & 01/09/02 & 1145 & 243 & 0 \\
\hline & 11413700 & 01/09/02 & 1145 & 243 & 13 \\
\hline & 11413700 & 01/11/02 & 1220 & 194 & 2 \\
\hline & 11413700 & $01 / 14 / 02$ & 1155 & 2090 & 2 \\
\hline & 11413700 & $01 / 16 / 02$ & 1230 & 2550 & 14 \\
\hline
\end{tabular}

Table A1c. Suspended-sediment concentration samples and associated instantaneous streamflow for the Yuba River below New Colgate Powerplant near French Corral (YRC) collected during water years 2001, 2002, and 2003.

[USGS Marina sediment laboratory uses $0.5 \mathrm{mg} / \mathrm{L}$ (milligram per liter) as the detection limit for reporting suspended-sediment concentration (SSC); therefore, samples with SSC of less than $0.5 \mathrm{mg} / \mathrm{L}$ are reported as $0.25 \mathrm{mg} / \mathrm{L}$ (Helsel and Hirsch, 1992). $\mathrm{ft}^{3} / \mathrm{s}$, cubic feet per second]

\begin{tabular}{cccccc}
\hline $\begin{array}{c}\text { Map } \\
\text { identi- } \\
\text { fier }\end{array}$ & $\begin{array}{c}\text { Station } \\
\text { identifier }\end{array}$ & Date & Time & $\begin{array}{c}\text { Instan- } \\
\text { taneous } \\
\text { streamflow } \\
\left(\mathrm{ft}^{3} / \mathrm{s}\right)\end{array}$ & $\begin{array}{c}\text { Suspended- } \\
\text { sediment } \\
\text { concentra- } \\
\text { tion }(\mathrm{mg} / \mathrm{L})\end{array}$ \\
\hline YRC & 11413700 & $01 / 16 / 02$ & 1230 & 2550 & 1 \\
& 11413700 & $01 / 17 / 02$ & 1245 & 2770 & 2 \\
& 11413700 & $01 / 22 / 02$ & 1245 & 677 & 4 \\
& 11413700 & $01 / 24 / 02$ & 1205 & 1110 & 1 \\
& 11413700 & $01 / 24 / 02$ & 1205 & 1110 & 1 \\
& 11413700 & $01 / 28 / 02$ & 1245 & 963 & 4 \\
& 11413700 & $01 / 30 / 02$ & 1220 & 1640 & 2 \\
& 11413700 & $02 / 04 / 02$ & 1250 & 953 & 1
\end{tabular}

$\begin{array}{llll}11413700 & 02 / 04 / 02 & 1250 & 953\end{array}$

$\begin{array}{llll}11413700 & 02 / 11 / 02 & 1210 & 1180\end{array}$

$\begin{array}{lllll}11413700 & 02 / 13 / 02 & 1240 & 1060 & 5\end{array}$

$\begin{array}{lllll}11413700 & 02 / 15 / 02 & 1230 & 1070 & 2\end{array}$

$\begin{array}{lllll}11413700 & 02 / 15 / 02 & 1230 & 1070 & 3\end{array}$

$\begin{array}{lllll}11413700 & 02 / 21 / 02 & 1215 & 542 & 2\end{array}$

$\begin{array}{lllll}11413700 & 02 / 22 / 02 & 1205 & 281 & 4\end{array}$

$\begin{array}{lllll}11413700 & 02 / 22 / 02 & 1205 & 281 & 22\end{array}$

$\begin{array}{lllll}11413700 & 02 / 25 / 02 & 1210 & 1490 & 6\end{array}$

$\begin{array}{lllll}11413700 & 02 / 26 / 02 & 1215 & 1040 & 17\end{array}$

$\begin{array}{lllll}11413700 & 02 / 28 / 02 & 1210 & 607 & 3\end{array}$

$\begin{array}{lllll}11413700 & 03 / 01 / 02 & 1205 & 585 & 6\end{array}$

$\begin{array}{lllll}11413700 & 03 / 04 / 02 & 1150 & 1300 & 3\end{array}$

$\begin{array}{lllll}11413700 & 03 / 05 / 02 & 1210 & 1240 & 3\end{array}$

$\begin{array}{lllll}11413700 & 03 / 05 / 02 & 1210 & 1240 & 1\end{array}$

$\begin{array}{lllll}11413700 & 03 / 11 / 02 & 1210 & 2800 & 2\end{array}$

$\begin{array}{lllll}11413700 & 03 / 11 / 02 & 1210 & 2800 & 12\end{array}$

$\begin{array}{lllll}11413700 & 03 / 12 / 02 & 1155 & 2340 & 4\end{array}$

$\begin{array}{lllll}11413700 & 03 / 12 / 02 & 1155 & 2340 & 2\end{array}$

$\begin{array}{lllll}11413700 & 03 / 14 / 02 & 1200 & 1060 & 6\end{array}$

$\begin{array}{lllll}11413700 & 03 / 14 / 02 & 1200 & 1060 & 2\end{array}$

$\begin{array}{lllll}11413700 & 03 / 15 / 02 & 1210 & 1390 & 3\end{array}$

$\begin{array}{lllll}11413700 & 03 / 15 / 02 & 1210 & 1390 & 18\end{array}$

$\begin{array}{lllll}11413700 & 03 / 18 / 02 & 1200 & 2370 & 3\end{array}$

$\begin{array}{lllll}11413700 & 03 / 18 / 02 & 1200 & 2370 & 18\end{array}$

$\begin{array}{lllll}11413700 & 03 / 19 / 02 & 1210 & 1950 & 2\end{array}$

$\begin{array}{lllll}11413700 & 03 / 19 / 02 & 1210 & 1950 & 4\end{array}$

$\begin{array}{lllll}11413700 & 03 / 22 / 02 & 1210 & 2180 & 3\end{array}$

$\begin{array}{lllll}11413700 & 03 / 22 / 02 & 1210 & 2180 & 2\end{array}$

$\begin{array}{lllll}11413700 & 03 / 24 / 02 & 1130 & 1580 & 8\end{array}$

$\begin{array}{lllll}11413700 & 03 / 24 / 02 & 1130 & 1580 & 10\end{array}$

$\begin{array}{lllll}11413700 & 03 / 25 / 02 & 1210 & 2730 & 3\end{array}$

$\begin{array}{lllll}11413700 & 03 / 25 / 02 & 1210 & 2730 & 16\end{array}$

$\begin{array}{lllll}11413700 & 03 / 26 / 02 & 1210 & 2340 & 2\end{array}$

$\begin{array}{lllll}11413700 & 03 / 26 / 02 & 1210 & 2340 & 30\end{array}$

$\begin{array}{lllll}11413700 & 03 / 28 / 02 & 1200 & 2190 & 1\end{array}$

$\begin{array}{lllll}11413700 & 03 / 28 / 02 & 1200 & 2190 & 5\end{array}$

$\begin{array}{lllll}11413700 & 03 / 29 / 02 & 1205 & 2900 & 3\end{array}$

$\begin{array}{lllll}11413700 & 03 / 29 / 02 & 1205 & 2900 & 4\end{array}$

$\begin{array}{lllll}11413700 & 04 / 03 / 02 & 1200 & 2720 & 155\end{array}$ 
Table A1c. Suspended-sediment concentration samples and associated instantaneous streamflow for the Yuba River below New Colgate Powerplant near French Corral (YRC) collected during water years 2001, 2002, and 2003.

[USGS Marina sediment laboratory uses $0.5 \mathrm{mg} / \mathrm{L}$ (milligram per liter) as the detection limit for reporting suspended-sediment concentration (SSC); therefore, samples with SSC of less than $0.5 \mathrm{mg} / \mathrm{L}$ are reported as $0.25 \mathrm{mg} / \mathrm{L}$ (Helsel and Hirsch, 1992). $\mathrm{ft}^{3} / \mathrm{s}$, cubic feet per second]

\begin{tabular}{|c|c|c|c|c|c|}
\hline $\begin{array}{l}\text { Map } \\
\text { identi- } \\
\text { fier }\end{array}$ & $\begin{array}{l}\text { Station } \\
\text { identifier }\end{array}$ & Date & Time & $\begin{array}{c}\text { Instan- } \\
\text { taneous } \\
\text { streamflow } \\
\left(\mathrm{ft}^{3} / \mathrm{s}\right)\end{array}$ & $\begin{array}{c}\text { Suspended- } \\
\text { sediment } \\
\text { concentra- } \\
\text { tion (mg/L) }\end{array}$ \\
\hline \multirow[t]{48}{*}{ YRC } & 11413700 & $04 / 03 / 02$ & 1200 & 2720 & 2 \\
\hline & 11413700 & $04 / 05 / 02$ & 1205 & 2070 & 2 \\
\hline & 11413700 & $04 / 05 / 02$ & 1205 & 2070 & 2 \\
\hline & 11413700 & $04 / 08 / 02$ & 1215 & 3130 & 3 \\
\hline & 11413700 & 04/08/02 & 1215 & 3130 & 10 \\
\hline & 11413700 & $04 / 09 / 02$ & 1220 & 3040 & 1 \\
\hline & 11413700 & $04 / 09 / 02$ & 1220 & 3040 & 1 \\
\hline & 11413700 & $04 / 11 / 02$ & 1155 & 2440 & 5 \\
\hline & 11413700 & $04 / 11 / 02$ & 1155 & 2440 & 0 \\
\hline & 11413700 & $04 / 15 / 02$ & 1200 & 2650 & 1 \\
\hline & 11413700 & $04 / 15 / 02$ & 1200 & 2650 & 1 \\
\hline & 11413700 & $04 / 16 / 02$ & 1155 & 3320 & 1 \\
\hline & 11413700 & $04 / 16 / 02$ & 1155 & 3320 & 2 \\
\hline & 11413700 & $04 / 18 / 02$ & 1155 & 2580 & 5 \\
\hline & 11413700 & $04 / 18 / 02$ & 1155 & 2580 & 2 \\
\hline & 11413700 & $04 / 19 / 02$ & 1225 & 3260 & 2 \\
\hline & 11413700 & 04/19/02 & 1225 & 3260 & 2 \\
\hline & 11413700 & $04 / 22 / 02$ & 1145 & 2580 & 8 \\
\hline & 11413700 & $04 / 22 / 02$ & 1145 & 2580 & 3 \\
\hline & 11413700 & $04 / 23 / 02$ & 1205 & 3520 & 16 \\
\hline & 11413700 & $04 / 23 / 02$ & 1205 & 3520 & 1 \\
\hline & 11413700 & $04 / 25 / 02$ & 1210 & 3260 & 5 \\
\hline & 11413700 & $04 / 25 / 02$ & 1210 & 3260 & 1 \\
\hline & 11413700 & $04 / 26 / 02$ & 1155 & 2960 & 12 \\
\hline & 11413700 & $04 / 26 / 02$ & 1155 & 2960 & 1 \\
\hline & 11413700 & $04 / 30 / 02$ & 1240 & 2970 & 1 \\
\hline & 11413700 & $04 / 30 / 02$ & 1240 & 2970 & 3 \\
\hline & 11413700 & $05 / 02 / 02$ & 1150 & 3100 & 1 \\
\hline & 11413700 & $05 / 02 / 02$ & 1150 & 3100 & 4 \\
\hline & 11413700 & $05 / 03 / 02$ & 1155 & 3280 & 3 \\
\hline & 11413700 & $05 / 03 / 02$ & 1155 & 3280 & 2 \\
\hline & 11413700 & 05/06/02 & 1145 & 3300 & 2 \\
\hline & 11413700 & $05 / 06 / 02$ & 1145 & 3300 & 4 \\
\hline & 11413700 & 05/07/02 & 1205 & 3280 & 2 \\
\hline & 11413700 & $05 / 07 / 02$ & 1205 & 3280 & 3 \\
\hline & 11413700 & $05 / 09 / 02$ & 1210 & 3300 & 6 \\
\hline & 11413700 & 05/09/02 & 1210 & 3300 & 3 \\
\hline & 11413700 & $05 / 10 / 02$ & 1150 & 3230 & 1 \\
\hline & 11413700 & $05 / 10 / 02$ & 1150 & 3230 & 2 \\
\hline & 11413700 & $05 / 13 / 02$ & 1145 & no data & 1 \\
\hline & 11413700 & $05 / 13 / 02$ & 1145 & no data & 4 \\
\hline & 11413700 & $05 / 14 / 02$ & 1210 & no data & 2 \\
\hline & 11413700 & $05 / 14 / 02$ & 1210 & no data & 1 \\
\hline & 11413700 & $05 / 16 / 02$ & 1150 & 1990 & 2 \\
\hline & 11413700 & $05 / 16 / 02$ & 1150 & 1990 & 2 \\
\hline & 11413700 & $05 / 17 / 02$ & 1200 & 1860 & 1 \\
\hline & 11413700 & $05 / 17 / 02$ & 1200 & 1860 & 2 \\
\hline & 11413700 & $05 / 20 / 02$ & 1205 & 2190 & 3 \\
\hline
\end{tabular}

Table A1c. Suspended-sediment concentration samples and associated instantaneous streamflow for the Yuba River below New Colgate Powerplant near French Corral (YRC) collected during water years 2001, 2002, and 2003.

[USGS Marina sediment laboratory uses $0.5 \mathrm{mg} / \mathrm{L}$ (milligram per liter) as the detection limit for reporting suspended-sediment concentration (SSC); therefore, samples with SSC of less than $0.5 \mathrm{mg} / \mathrm{L}$ are reported as $0.25 \mathrm{mg} / \mathrm{L}$ (Helsel and Hirsch, 1992). ft³/s, cubic feet per second]

\begin{tabular}{|c|c|c|c|c|c|}
\hline $\begin{array}{l}\text { Map } \\
\text { identi- } \\
\text { fier }\end{array}$ & $\begin{array}{c}\text { Station } \\
\text { identifier }\end{array}$ & Date & Time & $\begin{array}{c}\text { Instan- } \\
\text { taneous } \\
\text { streamflow } \\
\left(\mathrm{ft}^{3} / \mathrm{s}\right)\end{array}$ & $\begin{array}{l}\text { Suspended- } \\
\text { sediment } \\
\text { concentra- } \\
\text { tion (mg/L) }\end{array}$ \\
\hline \multirow[t]{37}{*}{ YRC } & 11413700 & $05 / 20 / 02$ & 1205 & 2190 & 2 \\
\hline & 11413700 & $05 / 21 / 02$ & 1205 & 2580 & 5 \\
\hline & 11413700 & $05 / 21 / 02$ & 1205 & 2580 & 2 \\
\hline & 11413700 & $05 / 23 / 02$ & 1210 & 2390 & 1 \\
\hline & 11413700 & $05 / 23 / 02$ & 1210 & 2390 & 2 \\
\hline & 11413700 & $05 / 24 / 02$ & 1210 & 2780 & 2 \\
\hline & 11413700 & $05 / 24 / 02$ & 1210 & 2780 & 2 \\
\hline & 11413700 & $05 / 28 / 02$ & 1200 & 3130 & 2 \\
\hline & 11413700 & $05 / 28 / 02$ & 1200 & 3130 & 1 \\
\hline & 11413700 & $05 / 30 / 02$ & 1130 & 2520 & 2 \\
\hline & 11413700 & 05/30/02 & 1130 & 2520 & 13 \\
\hline & 11413700 & $05 / 31 / 02$ & 1210 & 2620 & 0 \\
\hline & 11413700 & $05 / 31 / 02$ & 1210 & 2620 & 1 \\
\hline & 11413700 & $06 / 04 / 02$ & 1530 & 3190 & 2 \\
\hline & 11413700 & 06/04/02 & 1530 & 3190 & 1 \\
\hline & 11413700 & $06 / 06 / 02$ & 1500 & 3400 & 2 \\
\hline & 11413700 & 06/06/02 & 1500 & 3400 & 1 \\
\hline & 11413700 & $06 / 10 / 02$ & 1210 & 1740 & 1 \\
\hline & 11413700 & 06/10/02 & 1210 & 1740 & 1 \\
\hline & 11413700 & $06 / 11 / 02$ & 1205 & 2600 & 5 \\
\hline & 11413700 & 06/11/02 & 1205 & 2600 & 1 \\
\hline & 11413700 & 06/13/02 & 1215 & 1130 & 2 \\
\hline & 11413700 & 06/13/02 & 1215 & 1130 & 2 \\
\hline & 11413700 & $06 / 14 / 02$ & 1205 & 2920 & 2 \\
\hline & 11413700 & 06/14/02 & 1205 & 2920 & 3 \\
\hline & 11413700 & 06/17/02 & 1215 & 3240 & 2 \\
\hline & 11413700 & $06 / 17 / 02$ & 1215 & 3240 & 3 \\
\hline & 11413700 & 06/18/02 & 1205 & 3620 & 11 \\
\hline & 11413700 & $06 / 18 / 02$ & 1205 & 3620 & 0 \\
\hline & 11413700 & 06/20/02 & 1155 & 2520 & 2 \\
\hline & 11413700 & $06 / 20 / 02$ & 1155 & 2520 & 1 \\
\hline & 11413700 & $06 / 21 / 02$ & 1125 & 3440 & 1 \\
\hline & 11413700 & $06 / 21 / 02$ & 1125 & 3440 & 3 \\
\hline & 11413700 & $06 / 24 / 02$ & 1210 & 2530 & 2 \\
\hline & 11413700 & $06 / 24 / 02$ & 1210 & 2530 & 3 \\
\hline & 11413700 & $06 / 28 / 02$ & 1200 & 2970 & 1 \\
\hline & 11413700 & $06 / 28 / 02$ & 1200 & 2970 & 2 \\
\hline
\end{tabular}


Table A1d. Suspended-sediment concentration samples and associated instantaneous streamflow for the Yuba River below Englebright Dam near Smartville (YRE) collected during water years 2001, 2002, and 2003.

[USGS Marina sediment laboratory uses $0.5 \mathrm{mg} / \mathrm{L}$ (milligram per liter) as the detection limit for reporting suspended-sediment concentration (SSC); therefore, samples with SSC of less than $0.5 \mathrm{mg} / \mathrm{L}$ are reported as $0.25 \mathrm{mg} / \mathrm{L}$ (Helsel and Hirsch, 1992). $\mathrm{ft}^{3} / \mathrm{s}$, cubic feet per second]

\begin{tabular}{|c|c|c|c|c|c|}
\hline $\begin{array}{c}\text { Map } \\
\text { identi- } \\
\text { fier }\end{array}$ & $\begin{array}{l}\text { Station } \\
\text { identifier }\end{array}$ & Date & Time & $\begin{array}{l}\text { Instan- } \\
\text { taneous } \\
\text { stream- } \\
\text { flow } \\
\left(\mathrm{ft}^{3} / \mathrm{s}\right)\end{array}$ & $\begin{array}{c}\text { Sus- } \\
\text { pended- } \\
\text { sediment } \\
\text { concen- } \\
\text { tration } \\
\text { (mg/L) }\end{array}$ \\
\hline \multirow[t]{46}{*}{ YRE } & 11418000 & $01 / 12 / 01$ & 1500 & 941 & 2 \\
\hline & 11418000 & 02/02/01 & 1500 & 701 & 2 \\
\hline & 11418000 & 02/06/01 & 0930 & 688 & 1 \\
\hline & 11418000 & 02/10/01 & 1440 & 656 & 6 \\
\hline & 11418000 & 02/12/01 & 1410 & 692 & 2 \\
\hline & 11418000 & 02/13/01 & 1400 & 691 & 2 \\
\hline & 11418000 & 02/15/01 & 1405 & 691 & 2 \\
\hline & 11418000 & 02/16/01 & 1400 & 692 & 2 \\
\hline & 11418000 & 02/20/01 & 1420 & 690 & 3 \\
\hline & 11418000 & $02 / 22 / 01$ & 1400 & 1240 & 1 \\
\hline & 11418000 & 02/23/01 & 1405 & 1220 & 1 \\
\hline & 11418000 & 02/27/01 & 1250 & 1040 & 1 \\
\hline & 11418000 & 02/28/01 & 1130 & 946 & 4 \\
\hline & 11418000 & 03/06/01 & 1310 & 738 & 6 \\
\hline & 11418000 & 03/08/01 & 1255 & 745 & 3 \\
\hline & 11418000 & 03/13/01 & 1245 & 734 & 3 \\
\hline & 11418000 & 03/14/01 & 1335 & 731 & 3 \\
\hline & 11418000 & 03/15/01 & 1250 & 728 & 2 \\
\hline & 11418000 & 03/20/01 & 1245 & 721 & 10 \\
\hline & 11418000 & 03/21/01 & 1130 & 721 & 7 \\
\hline & 11418000 & 03/27/01 & 0925 & 725 & 4 \\
\hline & 11418000 & 04/03/01 & 1250 & 1090 & 4 \\
\hline & 11418000 & 04/05/01 & 1255 & 1085 & 2 \\
\hline & 11418000 & 04/10/01 & 1300 & 1070 & 1 \\
\hline & 11418000 & 04/10/01 & 1300 & 1070 & 1 \\
\hline & 11418000 & 04/12/01 & 1250 & 1070 & 3 \\
\hline & 11418000 & 04/12/01 & 1250 & 1070 & 3 \\
\hline & 11418000 & 04/17/01 & 1310 & no data & 8 \\
\hline & 11418000 & 04/17/01 & 1310 & no data & 2 \\
\hline & 11418000 & 04/19/01 & 1250 & no data & 1 \\
\hline & 11418000 & 04/19/01 & 1250 & no data & 1 \\
\hline & 11418000 & $04 / 24 / 01$ & 1305 & 880 & 1 \\
\hline & 11418000 & $04 / 24 / 01$ & 1305 & 880 & 1 \\
\hline & 11418000 & 04/26/01 & 1255 & 885 & 1 \\
\hline & 11418000 & 04/26/01 & 1255 & 885 & 1 \\
\hline & 11418000 & 05/01/01 & 1250 & 875 & 3 \\
\hline & 11418000 & 05/03/01 & 1245 & 994 & 3 \\
\hline & 11418000 & 05/08/01 & 1255 & 1190 & 5 \\
\hline & 11418000 & 05/10/01 & 1255 & 1130 & 2 \\
\hline & 11418000 & 05/15/01 & 1255 & 900 & 3 \\
\hline & 11418000 & 05/17/01 & 1250 & 850 & 2 \\
\hline & 11418000 & $05 / 24 / 01$ & 1245 & 880 & 1 \\
\hline & 11418000 & 05/30/01 & 1000 & 972 & 2 \\
\hline & 11418000 & 05/30/01 & 1245 & 978 & 3 \\
\hline & 11418000 & 06/01/01 & 1240 & 946 & 1 \\
\hline & 11418000 & 06/05/01 & 1245 & 972 & 2 \\
\hline
\end{tabular}

Table A1d. Suspended-sediment concentration samples and associated instantaneous streamflow for the Yuba River below Englebright Dam near Smartville (YRE) collected during water years 2001, 2002, and 2003.

[USGS Marina sediment laboratory uses $0.5 \mathrm{mg} / \mathrm{L}$ (milligram per liter) as the detection limit for reporting suspended-sediment concentration (SSC); therefore, samples with SSC of less than $0.5 \mathrm{mg} / \mathrm{L}$ are reported as $0.25 \mathrm{mg} / \mathrm{L}$ (Helsel and Hirsch, 1992). $\mathrm{ft}^{3} / \mathrm{s}$, cubic feet per second]

\begin{tabular}{|c|c|c|c|c|c|}
\hline $\begin{array}{l}\text { Map } \\
\text { identi- } \\
\text { fier }\end{array}$ & $\begin{array}{l}\text { Station } \\
\text { identifier }\end{array}$ & Date & Time & $\begin{array}{l}\text { Instan- } \\
\text { taneous } \\
\text { stream- } \\
\text { flow } \\
\left(\mathrm{ft}^{3} / \mathrm{s}\right)\end{array}$ & $\begin{array}{c}\text { Sus- } \\
\text { pended- } \\
\text { sediment } \\
\text { concen- } \\
\text { tration } \\
\text { (mg/L) }\end{array}$ \\
\hline \multirow{46}{*}{ YRE } & 11418000 & 06/07/01 & 1250 & 972 & 4 \\
\hline & 11418000 & 06/13/01 & 1255 & 946 & 2 \\
\hline & 11418000 & 06/15/01 & 1245 & 972 & 3 \\
\hline & 11418000 & 06/19/01 & 1215 & 1020 & 2 \\
\hline & 11418000 & 06/21/01 & 1215 & 1040 & 1 \\
\hline & 11418000 & 06/21/01 & 1230 & 1040 & 4 \\
\hline & 11418000 & 06/26/01 & 1245 & 994 & 3 \\
\hline & 11418000 & 06/28/01 & 1250 & 905 & 1 \\
\hline & 11418000 & 07/03/01 & 1245 & 962 & 1 \\
\hline & 11418000 & 07/05/01 & 1150 & 1920 & 5 \\
\hline & 11418000 & 07/10/01 & 1320 & 2090 & 2 \\
\hline & 11418000 & 07/12/01 & 1315 & 2120 & 1 \\
\hline & 11418000 & 07/17/01 & 1300 & 2100 & 6 \\
\hline & 11418000 & 07/19/01 & 1300 & 2130 & 1 \\
\hline & 11418000 & 07/24/01 & 1315 & 2120 & 3 \\
\hline & 11418000 & 07/26/01 & 1300 & 2120 & 2 \\
\hline & 11418000 & 07/31/01 & 1235 & 2110 & 1 \\
\hline & 11418000 & 08/03/01 & 1100 & 2000 & 1 \\
\hline & 11418000 & 08/07/01 & 1200 & 1930 & 1 \\
\hline & 11418000 & 08/15/01 & 1305 & 1900 & 2 \\
\hline & 11418000 & 08/21/01 & 1245 & 1920 & 1 \\
\hline & 11418000 & 08/29/01 & 1340 & 812 & 1 \\
\hline & 11418000 & 08/30/01 & 1600 & 812 & 0.25 \\
\hline & 11418000 & 09/05/01 & 1245 & 812 & 2 \\
\hline & 11418000 & 09/11/01 & 1205 & 600 & 1 \\
\hline & 11418000 & 09/27/01 & 1420 & 628 & 2 \\
\hline & 11418000 & 09/30/01 & 2330 & 673 & 2 \\
\hline & 11418000 & $10 / 03 / 01$ & 1510 & 554 & 2 \\
\hline & 11418000 & $10 / 10 / 01$ & 1300 & 673 & 2 \\
\hline & 11418000 & $10 / 17 / 01$ & 1400 & 656 & 5 \\
\hline & 11418000 & $10 / 24 / 01$ & 1030 & 895 & 2 \\
\hline & 11418000 & $10 / 25 / 01$ & 1020 & 875 & 2 \\
\hline & 11418000 & $11 / 06 / 01$ & 1015 & no data & 3 \\
\hline & 11418000 & $11 / 27 / 01$ & 1500 & no data & 1 \\
\hline & 11418000 & $11 / 29 / 01$ & 1000 & 734 & 2 \\
\hline & 11418000 & $12 / 04 / 01$ & 0940 & 1275 & 4 \\
\hline & 11418000 & $12 / 13 / 01$ & 1000 & 624 & 5 \\
\hline & 11418000 & $12 / 13 / 01$ & 1300 & 624 & 9 \\
\hline & 11418000 & $12 / 15 / 01$ & 1115 & 628 & 4 \\
\hline & 11418000 & $12 / 27 / 01$ & 0920 & 826 & 4 \\
\hline & 11418000 & 01/03/02 & 0925 & 1640 & 8 \\
\hline & 11418000 & 01/04/02 & 1220 & 1570 & 9 \\
\hline & 11418000 & 01/04/02 & 1220 & 1570 & 8 \\
\hline & 11418000 & 01/08/02 & 1230 & 1960 & 8 \\
\hline & 11418000 & 01/10/02 & 0930 & 1960 & 5 \\
\hline & 11418000 & $01 / 15 / 02$ & 1240 & 1970 & 3 \\
\hline
\end{tabular}


Table A1d. Suspended-sediment concentration samples and associated instantaneous streamflow for the Yuba River below Englebright Dam near Smartville (YRE) collected during water years 2001, 2002, and 2003.

[USGS Marina sediment laboratory uses $0.5 \mathrm{mg} / \mathrm{L}$ (milligram per liter) as the detection limit for reporting suspended-sediment concentration (SSC); therefore, samples with SSC of less than $0.5 \mathrm{mg} / \mathrm{L}$ are reported as $0.25 \mathrm{mg} / \mathrm{L}$ (Helsel and Hirsch, 1992). $\mathrm{ft}^{3} / \mathrm{s}$, cubic feet per second]

\begin{tabular}{|c|c|c|c|c|c|}
\hline $\begin{array}{l}\text { Map } \\
\text { identi- } \\
\text { fier }\end{array}$ & $\begin{array}{l}\text { Station } \\
\text { identifier }\end{array}$ & Date & Time & $\begin{array}{c}\text { Instan- } \\
\text { taneous } \\
\text { stream- } \\
\text { flow } \\
\left(\mathrm{ft}^{3} / \mathrm{s}\right)\end{array}$ & $\begin{array}{c}\text { Sus- } \\
\text { pended- } \\
\text { sediment } \\
\text { concen- } \\
\text { tration } \\
\text { (mg/L) }\end{array}$ \\
\hline \multirow[t]{46}{*}{ YRE } & 11418000 & $01 / 15 / 02$ & 1240 & 1970 & 4 \\
\hline & 11418000 & 01/18/02 & 0920 & 1985 & 3 \\
\hline & 11418000 & 01/23/02 & 1230 & 1610 & 2 \\
\hline & 11418000 & $01 / 25 / 02$ & 1220 & 1610 & 3 \\
\hline & 11418000 & $01 / 25 / 02$ & 1220 & 1610 & 3 \\
\hline & 11418000 & $01 / 29 / 02$ & 1240 & 1610 & 3 \\
\hline & 11418000 & 02/05/02 & 0930 & 1600 & 5 \\
\hline & 11418000 & $02 / 14 / 02$ & 1305 & 1570 & 2 \\
\hline & 11418000 & $02 / 14 / 02$ & 1305 & 1570 & 1 \\
\hline & 11418000 & 02/20/02 & 1250 & 1590 & 2 \\
\hline & 11418000 & 02/27/02 & 1255 & 1580 & 7 \\
\hline & 11418000 & 03/05/02 & 1030 & 1570 & 9 \\
\hline & 11418000 & 03/13/02 & 1235 & no data & 7 \\
\hline & 11418000 & 03/13/02 & 1235 & no data & 8 \\
\hline & 11418000 & 03/20/02 & 1230 & 2140 & 6 \\
\hline & 11418000 & 03/20/02 & 1230 & 2140 & 4 \\
\hline & 11418000 & 03/27/02 & 1245 & 2160 & 5 \\
\hline & 11418000 & 03/27/02 & 1245 & 2160 & 6 \\
\hline & 11418000 & 04/02/02 & 1000 & 2140 & 6 \\
\hline & 11418000 & 04/10/02 & 1155 & 2140 & 3 \\
\hline & 11418000 & 04/10/02 & 1155 & 2140 & 2 \\
\hline & 11418000 & $04 / 12 / 02$ & 1430 & 2150 & 3 \\
\hline & 11418000 & $04 / 12 / 02$ & 1430 & 2150 & 2 \\
\hline & 11418000 & $04 / 12 / 02$ & 1430 & 2150 & 2 \\
\hline & 11418000 & $04 / 12 / 02$ & 1430 & 2150 & 1 \\
\hline & 11418000 & $04 / 12 / 02$ & 1430 & 2150 & 2 \\
\hline & 11418000 & 04/17/02 & 1235 & 2140 & 1 \\
\hline & 11418000 & $04 / 24 / 02$ & 1225 & 2140 & 1 \\
\hline & 11418000 & $04 / 24 / 02$ & 1225 & 2140 & 1 \\
\hline & 11418000 & 05/01/02 & 1210 & 2270 & 2 \\
\hline & 11418000 & 05/01/02 & 1210 & 2270 & 2 \\
\hline & 11418000 & 05/03/02 & 1000 & 2280 & 1 \\
\hline & 11418000 & 05/08/02 & 1245 & 2400 & 2 \\
\hline & 11418000 & 05/08/02 & 1245 & 2400 & 3 \\
\hline & 11418000 & 05/15/02 & 1245 & 2060 & 1 \\
\hline & 11418000 & 05/15/02 & 1245 & 2060 & 1 \\
\hline & 11418000 & $05 / 22 / 02$ & 1240 & 2000 & 2 \\
\hline & 11418000 & $05 / 22 / 02$ & 1240 & 2000 & 2 \\
\hline & 11418000 & 05/29/02 & 1240 & 1995 & 2 \\
\hline & 11418000 & 05/29/02 & 1240 & 1995 & 3 \\
\hline & 11418000 & 06/07/02 & 1045 & 2010 & 2 \\
\hline & 11418000 & 06/07/02 & 1045 & 2010 & 0.25 \\
\hline & 11418000 & 06/12/02 & 1030 & 2000 & 2 \\
\hline & 11418000 & 06/12/02 & 1245 & 2000 & 2 \\
\hline & 11418000 & 06/12/02 & 1245 & 2000 & 1 \\
\hline & 11418000 & 06/19/02 & 1145 & 2010 & 0.25 \\
\hline
\end{tabular}

Table A1d. Suspended-sediment concentration samples and associated instantaneous streamflow for the Yuba River below Englebright Dam near Smartville (YRE) collected during water years 2001, 2002, and 2003.

[USGS Marina sediment laboratory uses $0.5 \mathrm{mg} / \mathrm{L}$ (milligram per liter) as the detection limit for reporting suspended-sediment concentration (SSC); therefore, samples with SSC of less than $0.5 \mathrm{mg} / \mathrm{L}$ are reported as $0.25 \mathrm{mg} / \mathrm{L}$ (Helsel and Hirsch, 1992). $\mathrm{ft}^{3} / \mathrm{s}$, cubic feet per second]

\begin{tabular}{|c|c|c|c|c|c|}
\hline $\begin{array}{c}\text { Map } \\
\text { identi- } \\
\text { fier }\end{array}$ & $\begin{array}{l}\text { Station } \\
\text { identifier }\end{array}$ & Date & Time & $\begin{array}{l}\text { Instan- } \\
\text { taneous } \\
\text { stream- } \\
\text { flow } \\
\left(\mathrm{ft}^{3} / \mathrm{s}\right)\end{array}$ & $\begin{array}{c}\text { Sus- } \\
\text { pended- } \\
\text { sediment } \\
\text { concen- } \\
\text { tration } \\
\text { (mg/L) }\end{array}$ \\
\hline \multirow[t]{46}{*}{ YRE } & 11418000 & $06 / 19 / 02$ & 1145 & 2010 & 2 \\
\hline & 11418000 & $06 / 27 / 02$ & 1230 & 2170 & 1 \\
\hline & 11418000 & $06 / 27 / 02$ & 1230 & 2170 & 1 \\
\hline & 11418000 & $11 / 01 / 02$ & 1257 & 951 & 1 \\
\hline & 11418000 & $11 / 01 / 02$ & 1257 & 951 & 1 \\
\hline & 11418000 & $11 / 01 / 02$ & 1300 & 951 & 1 \\
\hline & 11418000 & $11 / 11 / 02$ & 1010 & no data & 0.25 \\
\hline & 11418000 & $11 / 12 / 02$ & 1225 & no data & 1 \\
\hline & 11418000 & $11 / 12 / 02$ & 1225 & no data & 0.25 \\
\hline & 11418000 & $11 / 25 / 02$ & 1230 & no data & 2 \\
\hline & 11418000 & $11 / 25 / 02$ & 1230 & no data & 2 \\
\hline & 11418000 & $12 / 04 / 02$ & 1220 & no data & 0.25 \\
\hline & 11418000 & $12 / 04 / 02$ & 1220 & no data & 1 \\
\hline & 11418000 & $12 / 11 / 02$ & 1235 & no data & 3 \\
\hline & 11418000 & $12 / 11 / 02$ & 1235 & no data & 2 \\
\hline & 11418000 & $12 / 20 / 02$ & 1215 & 1040 & 30 \\
\hline & 11418000 & $12 / 20 / 02$ & 1215 & 1040 & 33 \\
\hline & 11418000 & $12 / 23 / 02$ & 1300 & 1080 & 33 \\
\hline & 11418000 & $12 / 23 / 02$ & 1300 & 1080 & 34 \\
\hline & 11418000 & $12 / 30 / 02$ & 1350 & 2360 & 11 \\
\hline & 11418000 & $12 / 30 / 02$ & 1350 & 2360 & 11 \\
\hline & 11418000 & $01 / 08 / 03$ & 1145 & 1290 & 9 \\
\hline & 11418000 & $01 / 08 / 03$ & 1145 & 1290 & 8 \\
\hline & 11418000 & $01 / 16 / 03$ & 1245 & 1930 & 4 \\
\hline & 11418000 & $01 / 16 / 03$ & 1245 & 1930 & 4 \\
\hline & 11418000 & $01 / 23 / 03$ & 1200 & no data & 3 \\
\hline & 11418000 & $01 / 23 / 03$ & 1200 & no data & 3 \\
\hline & 11418000 & $02 / 05 / 03$ & 1215 & 2410 & 4 \\
\hline & 11418000 & $02 / 05 / 03$ & 1215 & 2410 & 3 \\
\hline & 11418000 & $02 / 14 / 03$ & 1230 & 2000 & 3 \\
\hline & 11418000 & $02 / 14 / 03$ & 1230 & 2000 & 2 \\
\hline & 11418000 & $02 / 17 / 03$ & 1150 & 2010 & 2 \\
\hline & 11418000 & $02 / 17 / 03$ & 1150 & 2010 & 2 \\
\hline & 11418000 & $02 / 28 / 03$ & 1220 & 2020 & 7 \\
\hline & 11418000 & $02 / 28 / 03$ & 1220 & 2020 & 3 \\
\hline & 11418000 & $03 / 07 / 03$ & 1215 & 2030 & 4 \\
\hline & 11418000 & 03/07/03 & 1215 & 2030 & 4 \\
\hline & 11418000 & $03 / 12 / 03$ & 1230 & 2030 & 2 \\
\hline & 11418000 & $03 / 12 / 03$ & 1230 & 2030 & 2 \\
\hline & 11418000 & $03 / 15 / 03$ & 1120 & 4810 & 1 \\
\hline & 11418000 & $03 / 15 / 03$ & 1120 & 4810 & 0.25 \\
\hline & 11418000 & $03 / 15 / 03$ & 1330 & 5300 & 4 \\
\hline & 11418000 & $03 / 15 / 03$ & 1330 & 5300 & 2 \\
\hline & 11418000 & 03/16/03 & 1000 & 2950 & 12 \\
\hline & 11418000 & $03 / 16 / 03$ & 1000 & 2950 & 2 \\
\hline & 11418000 & $03 / 16 / 03$ & 1300 & 3370 & 4 \\
\hline
\end{tabular}


Table A1d. Suspended-sediment concentration samples and associated instantaneous streamflow for the Yuba River below Englebright Dam near Smartville (YRE) collected during water years 2001, 2002, and 2003.

[USGS Marina sediment laboratory uses $0.5 \mathrm{mg} / \mathrm{L}$ (milligram per liter) as the detection limit for reporting suspended-sediment concentration (SSC); therefore, samples with SSC of less than $0.5 \mathrm{mg} / \mathrm{L}$ are reported as $0.25 \mathrm{mg} / \mathrm{L}$ (Helsel and Hirsch, 1992). $\mathrm{ft}^{3} / \mathrm{s}$, cubic feet per second]

\begin{tabular}{|c|c|c|c|c|c|}
\hline $\begin{array}{l}\text { Map } \\
\text { identi- } \\
\text { fier }\end{array}$ & $\begin{array}{l}\text { Station } \\
\text { identifier }\end{array}$ & Date & Time & $\begin{array}{c}\text { Instan- } \\
\text { taneous } \\
\text { stream- } \\
\text { flow } \\
\left(\mathrm{ft}^{3} / \mathrm{s}\right)\end{array}$ & $\begin{array}{c}\text { Sus- } \\
\text { pended- } \\
\text { sediment } \\
\text { concen- } \\
\text { tration } \\
\text { (mg/L) }\end{array}$ \\
\hline \multirow[t]{25}{*}{ YRE } & 11418000 & $03 / 16 / 03$ & 1300 & 3370 & 3 \\
\hline & 11418000 & $03 / 16 / 03$ & 1615 & 3960 & 3 \\
\hline & 11418000 & $03 / 16 / 03$ & 1615 & 3960 & 2 \\
\hline & 11418000 & $03 / 17 / 03$ & 1045 & 4200 & 16 \\
\hline & 11418000 & $03 / 17 / 03$ & 1045 & 4200 & 15 \\
\hline & 11418000 & $03 / 21 / 03$ & 1145 & no data & 9 \\
\hline & 11418000 & $03 / 21 / 03$ & 1145 & no data & 9 \\
\hline & 11418000 & $04 / 08 / 03$ & 1400 & no data & 1 \\
\hline & 11418000 & $04 / 08 / 03$ & 1400 & no data & 2 \\
\hline & 11418000 & $04 / 15 / 03$ & 0930 & 3480 & 7 \\
\hline & 11418000 & $04 / 15 / 03$ & 0930 & 3480 & 5 \\
\hline & 11418000 & $04 / 22 / 03$ & 0955 & 1800 & 5 \\
\hline & 11418000 & $04 / 22 / 03$ & 0955 & 1800 & 4 \\
\hline & 11418000 & $05 / 02 / 03$ & 1155 & no data & 5 \\
\hline & 11418000 & $05 / 02 / 03$ & 1155 & no data & 6 \\
\hline & 11418000 & $05 / 05 / 03$ & 1155 & no data & 6 \\
\hline & 11418000 & $05 / 05 / 03$ & 1155 & no data & 6 \\
\hline & 11418000 & $05 / 16 / 03$ & 1220 & no data & 2 \\
\hline & 11418000 & $05 / 16 / 03$ & 1220 & no data & 1 \\
\hline & 11418000 & $05 / 22 / 03$ & 0948 & no data & 1 \\
\hline & 11418000 & $05 / 22 / 03$ & 0948 & no data & 1 \\
\hline & 11418000 & $05 / 27 / 03$ & 1430 & 4920 & 2 \\
\hline & 11418000 & $05 / 27 / 03$ & 1430 & 4920 & 2 \\
\hline & 11418000 & $05 / 29 / 03$ & 1230 & 5710 & 1 \\
\hline & 11418000 & $05 / 29 / 03$ & 1230 & 5710 & 2 \\
\hline
\end{tabular}




\section{Appendix 2.}

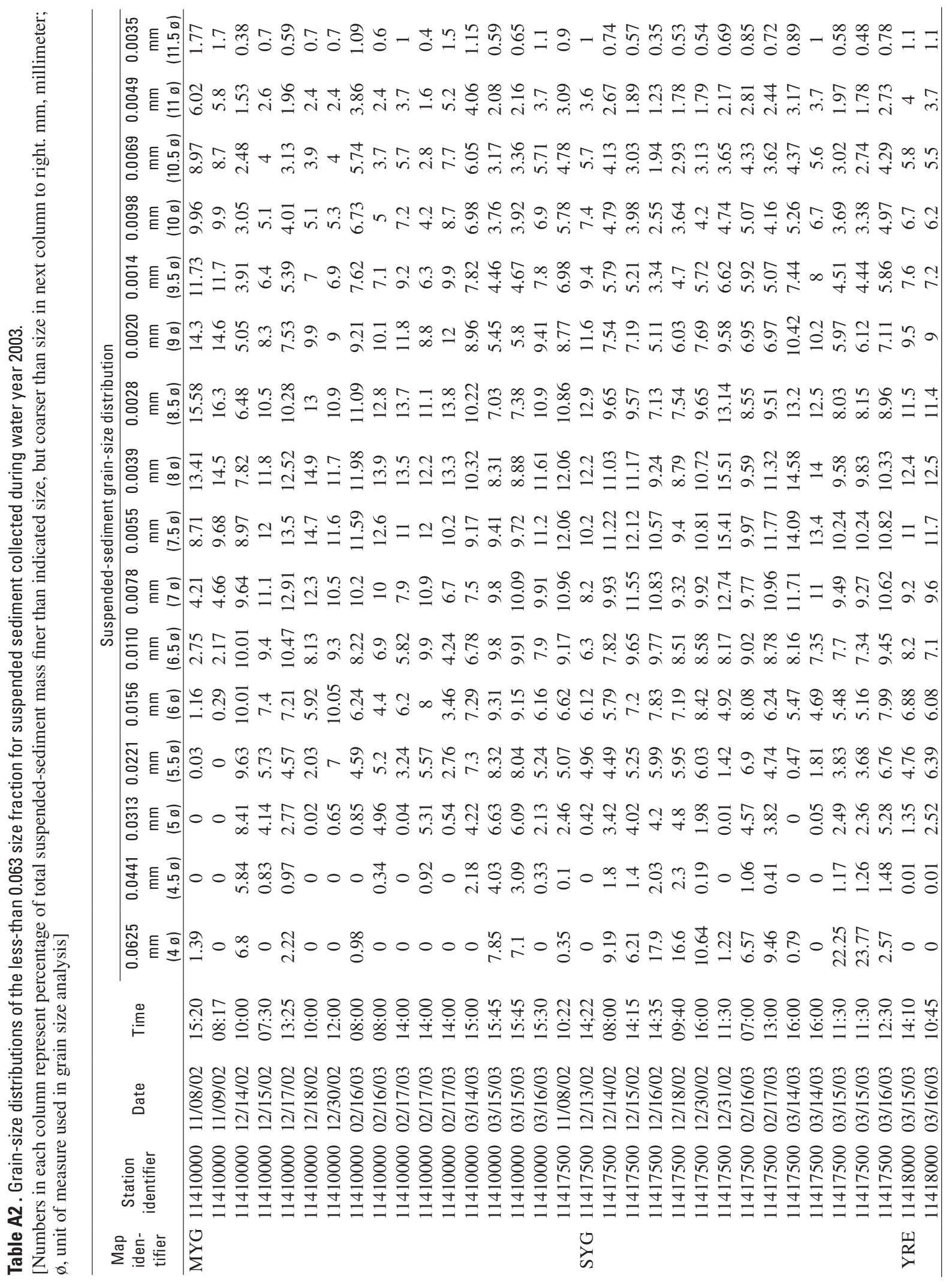

